Illinois State University

ISU ReD: Research and eData

Theses and Dissertations

3-25-2019

\title{
Chilled to the Bone: An Analysis on the Effects of Cold Temperatures and Weather Conditions Altering the Decomposition Process in Pig (Sus Scrofa) Remains
}

Katharine C. Woollen

Illinois State University, kcwooll95@gmail.com

Follow this and additional works at: https://ir.library.illinoisstate.edu/etd

Part of the Biological and Physical Anthropology Commons

\section{Recommended Citation}

Woollen, Katharine C., "Chilled to the Bone: An Analysis on the Effects of Cold Temperatures and Weather Conditions Altering the Decomposition Process in Pig (Sus Scrofa) Remains" (2019). Theses and Dissertations. 1059.

https://ir.library.illinoisstate.edu/etd/1059

This Thesis is brought to you for free and open access by ISU ReD: Research and eData. It has been accepted for inclusion in Theses and Dissertations by an authorized administrator of ISU ReD: Research and eData. For more information, please contact ISUReD@ilstu.edu. 


\section{CHILLED TO THE BONE: AN ANALYSIS ON THE EFFECTS OF COLD \\ TEMPERATURES AND WEATHER CONDITIONS ALTERING THE \\ DECOMPOSITION PROCESS IN PIG (SUS SCROFA)}

REMAINS

\section{KATHARINE C. WOOLLEN}

\section{Pages}

Temperature is one of the most crucial variables affecting the decomposition process, significantly increasing or decreasing the rate at which decomposition occurs. Few studies have been conducted to show how the effects of cold temperatures and weather conditions influence the postmortem interval (PMI). The PMI is defined as the amount of time that has passed since death. The purpose of this study was to evaluate estimations for the PMI when remains are exposed to cold temperatures and weather conditions. Secondly, this study seeks to explain whether variables (i.e., coverings, burial depth, soil $\mathrm{pH}$ ) can affect the decomposition process during colder months in central Illinois.

Over the course of five months, ten partial domestic pig specimens (Sus scrofa) were variably exposed to the elements of central Illinois. Information was gathered about how cold weather exposure affected these specimens from early January until early May. Four specimens were covered in white cotton t-shirts, four were wrapped in plastic garbage bags, and the remaining two were left uncovered on the ground surface. The covered pig human proxies were placed under the ground at depths of 6 and 18 inches. These variations were tested in order to 
gauge how a wide variety of decompositional conditions would affect decomposition during cold temperatures and associated weather conditions.

It was determined from the observations in this study that burial depth and types of coverings, or lack thereof, are significant to the decomposition process in cold weather conditions. This study concludes that precautions in determining the PMI must be taken when remains are identified during, or closely after, a period (circa four months) of cold temperatures have occurred.

KEYWORDS: decomposition, cold weather, pig remains, temperature, specimens. 


\title{
CHILLED TO THE BONE: AN ANALYSIS ON THE EFFECTS OF COLD TEMPERATURES AND WEATHER CONDITIONS ALTERING THE DECOMPOSITION PROCESS IN PIG (SUS SCROFA) \\ REMAINS
}

KATHARINE C. WOOLLEN

\author{
A Thesis Submitted in Partial \\ Fulfillment of the Requirements \\ for the Degree of \\ MASTER OF SCIENCE \\ Department of Sociology and Anthropology \\ ILLINOIS STATE UNIVERSITY
}


(C) 2019 Katharine C. Woollen 


\section{CHILLED TO THE BONE: AN ANALYSIS ON THE EFFECTS OF COLD TEMPERATURES AND WEATHER CONDITIONS ALTERING THE DECOMPOSITION PROCESS IN PIG (SUS SCROFA) REMAINS}

KATHARINE C. WOOLLEN

COMMITTEE MEMBERS:

Maria Ostendorf Smith, Chair Abigail Chipps Stone

Robert Rhykerd 


\section{ACKNOWLEDGMENTS}

First, I would like to thank my mentor and professor Dr. Maria Ostendorf Smith on constantly supporting me, and being ready to listen whenever an issue arose. You have been a constant support system for me throughout my academic career, and your encouragement reminds me that I am capable of anything. Without you, I don't think that I would be where I am today, and for that, I am forever grateful.

To Dr. Abigail Chipps Stone, thank you for listening to all the grisly details about my data collection throughout the course of this study. Thank you for all your guidance throughout this process, and for always having your door open. And to Dr. Rob Rhykerd, the genius who I would have been lost without. Thank you for your continued patience with me and being a part of this committee.

To Dr. Jacqueline Schneider, honestly, I don't think that I would have ever gotten into this field without you. Thank you for your continued support and being just as excited as I am about my results.

I would also like to thank my friends Kenzie May, Alexandria McDaniel, and Silas Chapman who I relied on more than they could ever imagine. You all kept me sane throughout this entire process!

Lastly, I would like to thank my parents, who braved negative temperatures, snowstorms, and decomposed flesh all for the sake of my thesis. You have encouraged me to pursue what I love throughout my entire life, even when that turned out to be forensic anthropology. None of this would have been possible without the both of you.

K.C.W. 


\section{CONTENTS}

Page

ACKNOWLEDGMENTS

TABLES - vi

FIGURES Nii

CHAPTER I: INTRODUCTION 1

CHAPTER II: LITERATURE REVIEW

Temperature Parameters $\quad 4$

Early Postmortem Events $\quad 6$

$\begin{array}{ll}\text { Rigor Mortis } & 6\end{array}$

$\begin{array}{ll}\text { Livor Mortis } & 6\end{array}$

$\begin{array}{ll}\text { Algor Mortis } & 7\end{array}$

$\begin{array}{ll}\text { Advanced Decomposition } & 7\end{array}$

$\begin{array}{ll}\text { Autolysis } & 7\end{array}$

$\begin{array}{ll}\text { Putrefaction } & 8\end{array}$

Variability in Human Decomposition $\quad 9$

$\begin{array}{ll}\text { Temperature } & 9\end{array}$

$\begin{array}{ll}\text { Moisture/Humidity } & 11\end{array}$

$\begin{array}{ll}\text { Oxygen } & 12\end{array}$

$\begin{array}{ll}\text { Insect Activity } & 12\end{array}$

Entomological Estimation of the PMI 14

$\begin{array}{ll}\text { Clothing and Coverings } & 15\end{array}$

$\begin{array}{ll}\text { Clothing } & 15\end{array}$ 
Other Coverings

Buried Remains

Soil pH

Cold Weather Studies

Micozzi (1986)

Roberts and Dabbs (2015)

Zugibe and Costello (1993)

Bunch (2009)

Komar (1998)

Central Illinois Weather Trends

CHAPTER III: MATERIALS AND METHODS

Site Construction

Site Security

Specimens

Placement of Specimens at Test Site

Two Months

Specimen J

Specimen B

Specimen A

Specimen F

Specimen E

Four Months

Specimen I 
Specimen D

Specimen C

Specimen $\mathrm{H}$

Specimen G

CHAPTER IV: RESULTS $\quad 48$

$\begin{array}{ll}\text { Weather Data } & 49\end{array}$

Two Month Examination $\quad 53$

Specimen A: Buried 18 inches in White Cotton T-shirt 53

Specimen B: Buried 6 inches in White Cotton T-shirt 54

Specimen E: Buried 18 inches in Plastic Garbage Bag 56

Specimen F: Buried 6 inches in Plastic Garbage Bag 57

$\begin{array}{ll}\text { Specimen J: Surface } & 58\end{array}$

$\begin{array}{ll}\text { January } & 58\end{array}$

$\begin{array}{ll}\text { February } & 59\end{array}$

$\begin{array}{ll}\text { March } & 61\end{array}$

$\begin{array}{ll}\text { Four Month Examination } & 63\end{array}$

Specimen C: Buried 18 inches in White Cotton T-shirt 63

Specimen D: Buried 6 inches in White Cotton t-shirt 65

Specimen G: Buried 18 inches in Plastic Garbage Bag 66

Specimen H: Buried 6 inches in Plastic Garbage Bag 67

$\begin{array}{ll}\text { Specimen I: Surface } & 68\end{array}$

$\begin{array}{ll}\text { January } & 69\end{array}$

$\begin{array}{ll}\text { February } & 70\end{array}$ 
Insect Infestation

Soil Analysis

How Cold Weather Affect Remains $\quad 92$

Decompositional Differences between Specimens 94

$\begin{array}{ll}\text { Specimens A and C } & 94\end{array}$

$\begin{array}{ll}\text { Specimens B and D } & 95\end{array}$

$\begin{array}{ll}\text { Specimens E and G } & 97\end{array}$

$\begin{array}{ll}\text { Specimens } \mathrm{F} \text { and } \mathrm{H} & 98\end{array}$

$\begin{array}{ll}\text { Specimens I and J } & 99\end{array}$

$\begin{array}{ll}\text { Garbage Bag vs. T-shirt } & 101\end{array}$

$\begin{array}{ll}\text { Buried vs. Surface } & 103\end{array}$

A More Accurate Representation of the PMI 105

$\begin{array}{ll}\text { Insect Observation } & 111\end{array}$

Soil Analysis Interpretation $\quad 114$

$\begin{array}{ll}\text { CHAPTER VI: CONCLUSION } & 118\end{array}$

$\begin{array}{ll}\text { REFERENCES } & 122\end{array}$

APPENDIX A: PARTIAL PIG (SUS SCROFA) PHOTOGRAPHS 130

APPENDIX B: NORMAL, IL WEATHER DATA 155 


\section{TABLES}

Table $\quad$ Page

1. Parameters for Cold, Cool, Warm, and Hot Temperatures 5

2. Average High and Low Temperature Readings in Normal, IL 24

3. Weight and Circumference of Each Specimen (A-J) Taken on January 9, $2018 \quad 30$

4. Each Specimens Weight and Circumference After Two-and Four-Month 48 Examinations

5. Soil Composition from Samples Taken at 6 and 18 inches Below the Soil Surface 90 


\section{FIGURES}

Figure

Page

1. Completed Dimensions of the Trench Constructed to House the Buried Specimens 26

2. Measurements of Depth, Width, and Length Taken After Completion of the Trench 26

3. Soil Sample Taken from Approximately 6 inches Below the Soil Surface

4. Stratigraphy and Layout of the Trench

5. Placement of Each Specimen at Depths of 6 and 18 inches in Cages 1-4

6. Cages 1-4 (18"x12"x14") within the Constructed Trench

7. Clothed Specimens Before Field Placement

8. Specimens Before Being Wrapped in Garbage Bags

9. Example of How the White Cotton T-Shirt were Wrapped Around Each Specimen

10. Example of How the Plastic Garbage Bags were Wrapped Around Each Specimen

11. Specimens That Would be Left Exposed on the Ground Surface Before Field

Placement

12. Scoring Sheet for Each Stage of Decomposition

13. Specimens at 18 inches

14. Specimen at 6 inches

15. Buried Cages Completely Covered

16. Construction and Completion of Cage 5

17. Top Portion of Specimen B Visible During the Two-Month Excavation

18. Top Portion of Specimen A Visible During the Two-Month Excavation

19. Top Portion of Specimen F During the Two-Month Excavation

20. Top Portion of Specimen E Excavated After Two Months 
21. Top Portion of Specimen D Excavated After Four Months 44

22. Top Portion of Specimen C Excavated After Four Months 45

23. Top Portion of Specimen H Excavated After Four Months 46

24. Top Portion of Specimen G Excavated After Four Months 47

25. High and Low Daily Temperatures from January to May 2018

26. Daily Humidity Readings Throughout the Study Period 50

27. Wind Speed Readings Throughout the Study Period 50

28. Small Maggot Mass Forming Underneath the Specimen in the Decompositional 82 Fluids

29. Maggot Mass has Diminished since the Previous Day (May 7, 2018) 82

30. Maggots within the T-shirt layers of Specimen D on the four-month examination 83 date (May 11, 2018)

31. Maggots on the Surface of the T-Shirt Covering Specimen C During the Four- Month Examination

32. Clothed in White Cotton T-shirts and Buried at 18 inches 95

33. Clothed in White Cotton T-Shirts and Buried at 6 inches 96

34. Specimens in Garbage Bags and Buried at 18 inches 98

35. Specimens Wrapped in Garbage Bags and Buried at 6 inches 99

36. Specimens Left Exposed on the Ground Surface 100 


\section{CHAPTER I: INTRODUCTION}

One of the first questions forensic investigators are asked upon arrival at a crime scene is how much time has elapsed since death. This is a question that is difficult to answer and, in instances of advanced decomposition, unobtainable. Human decomposition is a complicated process largely dependent on chemical, biological, and environmental factors that influence the rate of decomposition. Temperature, moisture, oxygen, insect activity, burial depth, and types of bodily coverings are a few of the conditions that are known to alter decomposition rates (Burns, 2016; Dix \& Graham, 2000; Haglund \& Sorg, 2002; Hayman \& Oxenham, 2016). At research centers like the University of Tennessee's Anthropological Research Facility in Knoxville, numerous studies analyzing various decompositional conditions have been conducted (Dautartas, 2009; Mann, Bass, \& Meadows 1990; Miller, 2002; Rodriguez \& Bass, 1983, 1985). Facilities

like those located in Knoxville provide parameters for forensic anthropologists, police, and government field agents to follow when they recover human remains. One of these parameters is the estimation of the amount of time that has passed since death, otherwise known as the postmortem interval (PMI). A carefully-constructed PMI estimate reduces the potential pool of decedents that the remains could belong to, later contributing to the identification of the individual (Megyesi et al., 2005). It is crucial that forensic scientists acquire extensive knowledge about decomposition rates in order to better estimate the PMI, so that their findings may contribute to the resolution of legal issues involved in the recovery of human remains.

Forensic research facilities located in areas that experience extended periods of cold temperatures and weather conditions have only recently been constructed, such as the Forensic Research Outdoor Station (FROST) in Marquette, Michigan. Currently, no studies have been 
released from this facility, and there are few existing studies (Bunch, 2009; Komar, 1998; Micozzi, 1986; Roberts \& Dabbs, 2015; Zugibe \& Costello, 1993) that analyze the effects of cold weather settings on the decomposition process. However, the majority of these studies examine the soft-tissue damage that occurs to remains that had been previously frozen and allowed to thaw (Micozzi, 1986; Roberts \& Dabbs, 2015; Zugibe \& Costello, 1993). While these assessments are useful in explaining some of the factors affecting decomposition sequences, they explain little about how remains are affected by natural (i.e., vacillating) cold weather settings. An understanding of the process of decomposition in cold weather settings can aid forensic anthropologists in identifying human remains, estimating how much time has elapsed since death, as well as understanding the circumstances surrounding the deceased's death when exposed to these particular weather settings. The present study seeks to answers three question regarding the decomposition process in cold weather settings:

1. How do cold temperatures and weather conditions alter the rate of decomposition?

2. Can a better estimation of the postmortem interval be created?

3. Will different test (i.e., buried, exposed, clothed, wrapped in plastic garbage bags) environments affect the decomposition process?

In order to better understand the effects that cold temperatures and weather conditions have on the decomposition process, this study examines ten partial pig (Sus scrofa) remains as they are exposed to a variety of conditions. These conditions consist of burials at contrasting depths (ground surface, 6 inches, 18 inches) and the presence of coverings (white cotton t-shirts and plastic garbage bags) or absence of coverings from January 9, 2018, until May 11, 2018 in central Illinois. At the two- and four-month interval, a specific set of the pig remains were analyzed to track the amount of decomposition that had occurred from the beginning of this 
study until their exhumation date (March 9, 2018 and May 11, 2018). Certain variables such as temperature and amount and type of precipitation (i.e., snow, sleet, rain, ice) are unique to this area, and provide insight into how remains decompose within this geographic region. To date, no research had been conducted prior to this study to explore the effects of burial depth and coverings in cold weather settings.

From this assessment, colder $\left(<37^{\circ} \mathrm{F} /<2.8^{\circ} \mathrm{C}\right)$ sustained ambient temperatures slow the chemical decomposition process in the pig (Sus scrofa) test samples. It is also observed that there will is little to no insect activity, resulting in less overall decomposition. Coverings and burial depth have an effect on decomposition rates. Over the four-month study period, it is concluded that all these factors result in markedly less decomposition. The examination of ten pig (Sus scrofa) proxies allowed this researcher to better understand the real-world cold temperature decomposition process when remains are subject to controlled conditions at two- and four-month intervals and documented weather conditions. 


\section{CHAPTER II: LITERATURE REVIEW}

A multitude of factors and areas of research must be considered when trying to determine the postmortem interval (PMI). The decomposition process can change dramatically depending on the physical and chemical factors that influence the rate of decay. In this review, the process of decomposition is discussed, as well as the various factors that can alter this process (i.e., temperature, moisture, oxygen, insect activity, clothing and coverings, burial conditions, and soil $\mathrm{pH})$. Each of these factors can greatly accelerate or decelerate decomposition over time, and assessing these conditions makes it possible to determine the PMI with more certainty. This review further discusses the current understanding of decomposition from thawing experiments.

\section{Temperature Parameters}

Cold weather environments are regions where ambient temperatures (daytime or nighttime) can reduce to below freezing $\left(<32^{\circ} \mathrm{F} /<0^{\circ} \mathrm{C}\right)$ for at least five hours in a 24-hour cycle for circa one third of the year. Currently, no range exists in the forensic literature to accurately define what "cold temperatures" are considered. In general, when dealing with human decomposition, cold temperatures should be defined as any temperature below $40^{\circ} \mathrm{F} / 4.4^{\circ} \mathrm{C}$ (Table 1) (Hyde, Haarmann, Lynne, Bucheli, \& Petrosino, 2015; Janaway, Percival, \& Wilson, 2009; Vass, 2001; Zhou \& Byard, 2011). The presence and reproduction of bacteria and microorganisms below this threshold is greatly reduced, and can cease completely in below freezing temperatures (Damann, Williams, \& Layton, 2015; Finley, Pechal, Benbow, Robertson, \& Javan, 2015; Hyde et al., 2015; Santa, 2017). Once bacteria are not allowed to proliferate, the decomposition process is dramatically reduced with the body not experiencing putrefaction (i.e., the most destructive stage of decomposition). In this study, temperatures below $37^{\circ} \mathrm{F} / 2.8^{\circ} \mathrm{C}$ were 
considered "cold." This was done so that a threshold would exist between no bacterial activity to the beginning presence of these organisms, promoting decomposition.

Cool temperatures are defined by Dix and Graham (2016) as being between $70-75^{\circ} \mathrm{F} / 21$ $23.9^{\circ} \mathrm{C}$ due to these temperatures being reduced from a living human's normal body temperature $\left(98.6^{\circ} \mathrm{F} / 37^{\circ} \mathrm{C}\right)$. However, temperatures between $40-70^{\circ} \mathrm{F} / 4.4-21^{\circ} \mathrm{C}$ are considered to be a more accurate representation of "cool" (Table 1). This range would experience an increase in bacterial and microorganism activity, as well as the presence of insects (above $50^{\circ} \mathrm{F} / 10^{\circ} \mathrm{C}$ ) $(\mathrm{Campobasso}$, Di Vella, \& Introna, 2001; Catts \& Goff, 1992; Amendt, Krettek, \& Zehner, 2004). Typically, temperatures between $70^{\circ} \mathrm{F}\left(20^{\circ} \mathrm{C}\right)$ and $100^{\circ} \mathrm{F}\left(37.8^{\circ} \mathrm{C}\right)$ (i.e., warm temperatures) promote the putrefactive stage of decomposition. Any temperature above $100^{\circ} \mathrm{F} / 37.8^{\circ} \mathrm{C}$ is considered "hot" due to the likelihood of insects (maggots) surviving being reduced and the remains becoming mummified (Campobasso et al., 2001; Galloway, Birkby, Jones, Henry, \& Parks, 1989)

Table 1

Parameters for Cold, Cool, Warm, and Hot Temperatures

\begin{tabular}{c|c|c|c|c}
\hline & \multicolumn{4}{|c}{ COLD TO HOT TEMPERATURE PARAMETERS } \\
\hline & Cold & Cool & Warm & Hot \\
\hline Temperature $\left({ }^{\circ} \mathrm{F} /{ }^{\circ} \mathrm{C}\right)$ & $<40 /<4.4$ & $40-70 / 4.4-21$ & $70-100 / 20-37.8$ & $>100 />37.8$ \\
\hline
\end{tabular}




\section{Early Postmortem Events}

\section{Rigor Mortis}

Rigor mortis refers to the process of muscle stiffening typically present during the first three hours after death and, generally, fully develops after approximately 10-12 hours (Dix \& Graham, 2000). At specifically room temperature $\left(\sim 72^{\circ} \mathrm{F} / 22.2^{\circ} \mathrm{C}\right)$, rigor is complete between three- and six-hours postmortem (Blakemore \& Jennett, 2001). On average, rigor can remain present for up to 24-36 hours before dissipating. During this time, all of the muscle tissue in the body becomes fixed and immobile. After rigor has subsided, the body will again become limp and flexible. The problem with relying on this stage of decomposition to determine the PMI is that a number of factors influence onset and duration. Besides environmental temperature, important factors are the internal body temperature, and the decedent's activity prior to death (Byers, 2017; Dix \& Graham, 2000; Hayman \& Oxenham, 2016; Iscan \& Steyn, 2013). Elevated environmental and body temperatures will accelerate the appearance and disappearance of rigor. Relevant to this study, cold temperatures (i.e., sustained temperatures of $<37^{\circ} \mathrm{F} /<2.8^{\circ} \mathrm{C}$ ) may retard or entirely prevent the onset of rigor mortis until the remains are allowed to thaw (Dix \& Graham, 2000).

\section{Livor Mortis}

Livor mortis (lividity) is characterized by the discoloration of the body after death due to the settling of blood that is no longer being circulated throughout the body (Dix \& Graham, 2000; Iscan \& Steyn 2013). It is noticeable within an hour after death and discoloration increases in intensity, becoming "fixed" at 8-10 hours after death. Lividity also becomes much darker as the PMI increases (Dix \& Graham, 2000; Hayman \& Oxenham, 2016). Prior to fixation, the body can be moved several times and the blood will resettle each time. However, after fixation, 
the blood will remain where it settled even after the body is repositioned (Miller, 2002). This can be useful in determining not only the PMI but the primary and secondary placement of the body. The only discernable difference that occurs to bodies exposed to cold temperature, is that blanching (i.e., whitening of the skin due to decreased blood flow) can occur for a longer period of time (Dix \& Graham, 2000; Hayman \& Oxenham, 2016; Iscan \& Steyn, 2013).

\section{Algor Mortis}

Algor mortis is the natural post-mortem temperature change of the body that takes place as the body temperature equilibrates with the ambient temperature at the location of death (Dix \& Graham, 2016; Haglund \& Sorg, 2002). Dix and Graham (2016) state that evaluating the onset of algor mortis is important within the first 10-12 hours after death when the body is exposed to a cool environment $\left(70-75^{\circ} \mathrm{F} / 21-23.9^{\circ} \mathrm{C}\right)$. In circumstances where the ambient temperature falls between this range $\left(70-75^{\circ} \mathrm{F}\right)$, the body cools at a rate of approximately $1.5^{\circ} \mathrm{F} /-16.9^{\circ} \mathrm{C}$ per hour. If death occurs in a warm $\left(70-100^{\circ} \mathrm{F} / 20-37.8^{\circ} \mathrm{C}\right)$ or arid environment (relative humidity $<40 \%$; dewpoint $<73^{\circ} \mathrm{F} /<22.8^{\circ} \mathrm{C}$ ), the postmortem body temperature will rise. Similarly, deaths that occur in colder contexts, the body will cool to that ambient temperature (Haglund \& Sorg, 2002).

\section{Advanced Decomposition}

\section{Autolysis}

Autolysis describes the degradation of bodily tissues caused by chemicals and bacteria that normally reside in the cell (Byers, 2017; Clark, Worrell, \& Pless, 1997; Gill-King, 1997; Iscan \& Steyn, 2013; Vass, 2001). It occurs within several hours after death most actively in the

digestive tract when there is no longer control by the living body and the fluids begin to digest all internal viscera (Byers, 2017). The speed at which autolysis occurs depends on various factors, such as cell type and, of course, temperature (Forbes, 2008; Hayman \& Oxenham, 2016; Iscan \& 
Steyn, 2013). Internally, decay begins in the intestines, suprarenal glands, and the spleen, all of which may putrefy within hours after death. The heart, kidneys, lungs, bladder, prostate, and uterus are among the last internal organs to undergo putrefaction (Iscan \& Steyn, 2013; Powers, 2005; Vass, 2001).

Anywhere from 24-48 hours postmortem, autolytic changes are externally visible. Specifically, the abdominal region (e.g., near the cecum) takes on a green discoloration as a result of sulfhaemoglobin and iron sulfide reacting with one another and creating hydrogen sulfide in the large intestine (Gonzalex, 1954; Love \& Marks, 2003). Cells between the epidermis and dermis begin to break down causing the epidermal layer to slip off the remains, known as skin slippage (Clark et al., 1997; Forbes, 2008; Gill-King, 1997). As a result of epidermal destruction, the hair and nails also become loosened and fall off (Clark et al., 1997; Iscan \& Steyn, 2013).

\section{Putrefaction}

Putrefaction is the result of autolysis, resulting in the production of strong odor (i.e., gases) and is the stage that causes the most dramatic soft tissue changes to a decomposing body (Clark et al., 1997; Dix \& Graham, 2016; Iscan \& Steyn, 2013; Janaway et al., 2009). As oxygen becomes depleted within the body, a more suitable anaerobic environment is created for the bacteria associated with putrefactive activity (Dautartas, 2009; Dix \& Graham, 2016). Putrefaction is extremely variable in its time and duration due to the conditions in which the remains are found (i.e., moisture, temperature, body composition, buried, health). Typically, this stage of decomposition commences 48 to 72 hours after death. The green discoloration that commenced during autolysis spreads to other areas of the body (i.e., trunk, neck, face, and limbs). Love and Marks (2003) state that the green discoloration is often inconsistent and a 
"marbling" effect is created over the body surface. Along with marbling, skin blisters and bloating associated with anaerobic decay build in the trunk, abdomen, and scrotum (Iscan \& Steyn, 2013; Clark et al., 1997; Vass, 2001).

As putrefaction progresses, mounting internal pressure from the buildup of gases (bloating) causes the tongue and eyes to protrude. Gases also cause accumulated fluids from within the body to be expelled through the nose, mouth and anus (Iscan \& Steyn, 2013; Knight, 1997; Vass, 2001). During this period, trapped gases may swell the body to such a degree that the abdomen ruptures, causing the release of the gases that have built up internally.

Bloating ultimately subsides and the remaining soft tissues continue to breakdown and deteriorate. Before bloating has entirely ceased, initial skeletonization begins, generally on the face (Galloway, Birkby, Jones, Henry, \& Parks, 1989; Iscan \& Steyn, 2013; Love \& Marks, 2003; Vass, 2001).

\section{Variability in Human Decomposition}

Multiple factors can affect how remains decompose over time, resulting in its acceleration or deceleration, depending on the chemical or physical agent at work. The most influential variables include temperature, moisture or humidity, and oxygen content (Haglund \& Sorg, 2002; Iscan \& Steyn, 2013; Mann et al., 1990). At any death scene, these factors can also vary greatly over the decomposition process and understandably cause difficulty in determining the PMI.

\section{Temperature}

Mann et al. (1990) states that ambient temperature has the greatest effect on decomposition rate. When temperatures are cold or fall below freezing, the decomposition process is greatly abbreviated. Cold temperatures can prevent decomposition, except for the 
change in coloration of the skin from its natural color to orange or black (Byers, 2017; Dix \& Graham, 2000; Mann et al., 1990; Vass, 2001). These temperatures also inhibit the presence of insect and scavenger activity, resulting in greater preservation of the remains. In consistently cold environments, such as the Arctic and Antarctic, microorganisms remain present as long as there is some amount of liquid water surrounding the body, thus, continuing the decomposition process. In more temperate environments (i.e., with distinct seasons), cold-exposed microorganisms are less adapted to the extreme cold (i.e., sustained temperatures below freezing) and many species cannot survive (Brock \& Madigan, 1988; Byers, 2017; Pokines \& Symes, 2013; Vass et al., 2002; Zhou \& Byard, 2011).

Warmer temperatures (i.e., between $70^{\circ} \mathrm{F} / 20^{\circ} \mathrm{C}$ and $100^{\circ} \mathrm{F} / 37.8^{\circ} \mathrm{C}$ ) are known to promote a greater degree of bacterial and insect activity, aiding in the acceleration of the decomposition process (Haglund \& Sorg, 2002; Mann et al., 1990; Vass, 2001). While increased temperatures tend to accelerate decomposition rates, if temperatures are exceedingly high (sustained at $>100^{\circ} \mathrm{F} />37.8^{\circ} \mathrm{C}$ ) bacterial growth and replication can become prohibited (Micozzi, 1997). The most difficult time of the year and areas of the world to determine the PMI are in areas where temperatures fluctuate between warm $\left(70-100^{\circ} \mathrm{F} / 20-37.8^{\circ} \mathrm{C}\right)$ and cold $\left(<40^{\circ} \mathrm{F} /<4.4^{\circ} \mathrm{C}\right)(\mathrm{Dix} \&$ Graham, 2000; Mann et al., 1990). When temperatures fluctuate between seasons, decomposition rates can slow down (cold temperatures) and then accelerate (warm temperatures) over the course of time, causing difficulty in determining the PMI. One scenario where human remains are subject to these conditions in a controlled way, is when remains are discovered at a crime scene. After removal from the scene, remains are refrigerated $\left(35-40^{\circ} \mathrm{F} / 1.7-4.4^{\circ} \mathrm{C}\right)$ until a postmortem examination is conducted. When the subject is re-exposed to room temperature (65- 
$\left.70^{\circ} \mathrm{F} / 18-21^{\circ} \mathrm{C}\right)$, the rate of decomposition will dramatically increase due to bacteria proliferating throughout the body (Dix \& Graham, 2000).

\section{Moisture/Humidity}

The amount of moisture, either in the form of humidity in the air or as water content (i.e., water bodies, soil moisture) surrounding a body can alter the duration of the decomposition process. Environments with a high moisture content (relative humidity above 50\%; dewpoint is $\sim 51^{\circ} \mathrm{F} / 10.6^{\circ} \mathrm{C}$ ) have been found to foster the decomposition process, while arid environments (relative humidity below $40 \%$, dewpoint is $\sim 73^{\circ} \mathrm{F} / 22.8^{\circ} \mathrm{C}$ ) retard decomposition rates (Aturaliya \& Lukasewyz, 1999; Burns, 2016; Byers, 2017; Dix \& Graham, 2000; Haglund \& Sorg, 2002; Mann et al., 1990). Mann et al. (1990) concluded that an increase in humidity appears to promote the reproduction and growth of insect activity. This is because the presence of moisture in the air and surrounding environment improves the chances of olfactory detection (i.e., sensory nerve cells in their antennae), because decompositional gases are water soluble (Haglund \& Sorg, 2002). Rainfall has not been shown to have an effect on maggot activity. In most cases, larvae will remain inside the body cavity and continue to feed (Mann et al., 1990).

Moisture, in varying amounts, also promotes the growth of microorganisms and bacteria, which can accelerate the decomposition process. In an arid environment, with little humidity, a body is usually subject to mummification (Byers, 2017; Dix \& Graham, 2000; Galloway et al., 1989). However, in a study by Mann et al. (1990), it was found that when a fresh cadaver was placed outside while there was snow on the ground, and the body was allowed to thaw as temperatures increased, in was observed that the remains decomposed internally, with the outer surface (skin) remaining mummified. After six years of further documentation, the cadaver subject to these conditions had changed very little (Mann et al., 1990). 


\section{Oxygen}

Oxygen is required for the promotion of aerobic bacterial activity, which significantly impact the putrefactive part of decomposition (Brock \& Madigan, 1988; Dautartas, 2009; Mant, 1987). When enzymes begin to fail due to a lack of available oxygen (e.g., physical environment or time of death), this leads to the beginning of the putrefactive process, known as autolysis. Anaerobes, which can survive in oxygen depleted environments as well as oxygenated environments, can also influence the decomposition process (Brock \& Madigan, 1988; Haglund \& Sorg, 2002). Mant (1987) found that bodies in a mass grave that were covered were less likely to experience as advanced a rate of decomposition as the remains that were left exposed to the air. Those that were exposed showed a loss of all thoracic organs and soft tissues (Mant, 1987). Remains that have been deeply buried, submerged, or found at high altitudes will decompose at a slower rate due to decreased amounts of oxygen available (Haglund \& Sorg, 2002).

\section{Insect Activity}

Insect activity causes an enormous amount of destruction to the soft tissues of remains, dramatically increasing the rate of decomposition. Blowflies (Calliphoridae) are often the first insects attracted to biological remains and are present within the minutes or hours after death (Burns, 2016; Byers, 2017; Campobasso et al., 2001; Catts \& Goff, 1992; Dix \& Graham, 2000; Haglund \& Sorg, 2002; Pickering \& Bachman, 2009). Necrophagous arthropods (species that feed on corpse tissue) detect the putrefactive gasses that are emitted by biological remains (Campobasso et al., 2001). Once blowflies have identified the remains, females lay their eggs, which generally take 6-40 hours to hatch. Blowflies typically lay their eggs around the eyes, nostrils, mouth, ears, genitals, and in shaded areas of the remains near the ground. These areas provide moisture and/or protection from the sun, allowing the larvae to have a greater chance of 
survival (Byers, 2017; Miller, 2002; Pickering \& Bachman, 2009). After hatching, maggots quickly begin to feed on the soft tissues. As maggots mature into adult flies, and new flies become present, the process of egg laying, egg hatching, feeding, and reproducing is repeated.

Other insects are also known to colonize remains at different decomposition stages, causing further destruction of the remains. These insects include Sarcophagidae (flesh fly), Silphidae (carrion beetle), Dermestidae (dermestid beetle), ants, bees, cockroaches, and wasps. Additionally, large populations of omnivorous insects (i.e., ants, bees, cockroaches, wasps, and beetles) can also feed upon the population of necrophagous species, retarding the rate of decomposition (Byers, 2017; Catts \& Goff, 1992; Haglund \& Sorg, 2002; Miller, 2002).

Temperature also plays an integral role into the presence of insect activity. The number of insects frequenting the body reduces during colder months, because any eggs will die if exposed to temperatures below $32^{\circ} \mathrm{F} / 0^{\circ} \mathrm{C}$, and any temperature below $50^{\circ} \mathrm{F} / 10^{\circ} \mathrm{C}$ tend to cease the majority of insect activity (Burns, 2016; Byers, 2017; Campobasso et al., 2001; Catts \& Goff, 1992; Haskell, Hall, Cervenka, \& Clark, 1997; Introna, Suman, \& Smialek, 1991; Rodriguez \& Bass, 1983; Pickering \& Bachman, 2009). Campobasso et al. (2001) states that while there is a less visible external presence of insects on biological remains when it is cold, internally, there may be some activity. Larval activity inside the remains can cause the temperature to rise substantially higher than the ambient temperature (Amendt et al., 2004; Keh, 1985; Rodriguez \& Bass, 1983). During this time, the heat produced from the large maggot mass inside the remains can cause steam vapor to rise off of the body (Amendt et al., 2004; Keh, 1985). When temperatures (ambient or internal) rise above $85^{\circ} \mathrm{F} / 29^{\circ} \mathrm{C}$, it can be harmful or lethal to larvae, especially when they are subject to direct sunlight (Campobasso et al., 2001; Haglund \& Sorg, 2002; Introna et al., 1991). If these high temperatures cause the external surface to become 
mummified, this can also delay or cease insect activity, because the soft tissues are difficult to reach due to a hardened external surface.

\section{Entomological estimation of the PMI}

While insects can cause human remains to deteriorate at a rapid pace, they can also be useful in estimating the postmortem interval (PMI). It was first mentioned by Krahmer in 1857 that there were innumerable opportunities for the use of insects in forensic cases to aid in determining the PMI (Amendt et al., 2004). Since that time, there have been numerous applications of forensic entomology to provide a better estimation of the PMI in forensic cases. Insect activity becomes useful after the initial stages of decomposition (rigor mortis, livor mortis, algor mortis), because it becomes increasingly difficult to determine the PMI after these stages of death (Amendt et al., 2004; Benecke, 1998; Catts \& Goff, 1992; Erzinclioglu, 1990). Identifying the adult species of insect, as well as the various stages of larval development help to determine the time of death (TOD) and PMI. Identification of mature insects and larvae is important to forensic investigations, because a complete lifecycle can vary between 9 -35 days depending on the specific species that has been identified (Byers, 2017; Haskell et al., 1997). However, once the species has been identified, an estimation of the PMI can be made to an accuracy of within 12 hours of death (Byers, 2017). Rodriguez and Bass (1983) state that if flies predominate, it is estimated that the PMI falls between 3-13 days. If beetles predominate, the estimate of the PMI is between 13- 25 days, but, if only beetles are present, the PMI is generally over 25 days (Byers, 2017; Rodriguez \& Bass, 1983). Though this technique is applicable to some forensic cases, many factors can affect the lifecycle of insects (i.e., temperature, weather conditions; burial placement). The use of insect in forensic investigations are becoming increasingly useful to 
determine the PMI and advances are being made to the science of forensic entomology each year (Byers, 2017; Catts \& Goff, 1992).

\section{Clothing and Coverings}

\section{Clothing}

Clothing and other various coverings (i.e., garbage bags, tarps, etc.) alter the rate of decomposition. The existing literature presents variable views as to how these coverings directly impact the amount of decomposition when remains are clothed or wrapped (Aturaliya \& Lukasewycz, 1999; Dautartas, 2009; Gonzales, Vance, Helpern, \& Umberger, 1954; Haglund, Reay, \& Swindler 1989; Kelly, Van Der Linde, \& Anderson, 2009; Matuszewski, Konwerski, Fratczak, \& Szafalowicz, 2014). Haglund et al. (1989) concluded that human remains wrapped in heavy clothing (i.e., multiple layers) inhibits the amount of animal scavenging, leading to a decrease in the overall rate of decomposition. The lack of animal scavenging allowed for further protection of the body, which would possibly lead to a better chance of identification. Gonzales et al. (1954) came to a similar conclusion, although, they found that clothed specimens decomposed at a much slower rate than those that were unclothed. They theorized that clothing promoted an increased amount of pressure around the remains, preventing bloating of the body tissues while also restricting the movement of organisms (Gonzales et al., 1954). Matuszewski et al. (2014) conducted a study on carcass mass and clothing on pig specimens (Sus scrofa). They observed how various body masses $(5-15 \mathrm{~kg}, 15.1-30 \mathrm{~kg}$, and $35-50 \mathrm{~kg})$, when wrapped in clothing, decomposed over time. Their results indicate that clothing had only a minor and inconsistent influence on the rate of decomposition.

Aturaliya and Lukasewycz (1999) found that clothing actually accelerates the rate of decomposition in dry environments. Their study examined two dead adult mice, which were both 
shaved and exposed to an environmental chamber of dry air. One of the mice was left nude; the other was wrapped in multiple layers of cotton strips enveloping the entire body. The conclusion of this study found that after 69 days, the nude mouse lost $58.6 \%$ of its original body weight while the clothed mouse lost 71.3\% (Aturaliya \& Lukasewycz, 1999). This study was later repeated with larger specimens (rats) and similar results were obtained.

Kelly et al. (2009) conducted an open field experiment at the University of the Free State, Bloemfontein, South Africa. Six domestic pig carcasses (Sus scrofa) were divided into three separate sample groups, each with a clothed specimen and one that remained nude. Kelly et al. (2009) found that clothed or wrapped carcasses produced larger maggot masses, which were allowed to move more freely across the specimen. It is believed that the clothing protected the maggots from sunlight for a longer period of time allowing for the maggot mass to increase in size over time. As a result of the coverings, the specimens also took longer to dry out and remained "wet" for a longer period of time (Kelly et al., 2009).

Similar conclusions were drawn by Cahoon's (1992) study analyzing the decomposition and deterioration of one nude and one clothed human cadaver. Cahoon observed that the clothed cadaver decomposed much more quickly than the cadaver that was left nude during the winter months at the Anthropology Research Facility (ARF) at the University of Tennessee, Knoxville. The results indicated that the clothed cadaver reached the bloating stage twice as quickly as the nude cadaver. This advanced progress of bloating was likely due to the clothing sheltering the growth and development of insects (Cahoon, 1992).

A study was later conducted by Miller (2002), which was also conducted at ARF to analyze the effects of clothing on human decomposition. Six unembalmed, clothed human cadavers were observed throughout Miller's (2002) one-year study. It was observed that the 
presence of clothing prevents decomposition of the dermis, while accelerating desiccation, leading to mummification. However, these observations were subject to change depending on the season or time of year the remains were analyzed. Miller (2002) states that there is no observable difference in decomposition for nude or clothed cadavers during the winter months.

\section{Other Coverings}

Dautartas (2009) examined the decomposition process of six human cadavers that were placed at the ARF at the University of Tennessee, Knoxville. Two cadavers were placed on the ground surface, two were wrapped in cotton thermal blankets, and the remaining two were wrapped in plastic tarps. The results from Dautartas' (2009) study concluded that there were noticeable differences in decomposition between each set of cadavers. The cotton thermal blanket caused the body to become mummified, while the plastic tarp led to moisture being trapped resulting in a "wet" decomposition. The plastic also prolonged insect activity, which contrasts with what was observed with the cadavers on the ground surface.

Manhein (1997) analyzed several forensic cases from Louisiana, in which the bodies had been wrapped using various materials. The first body discussed was wrapped in heavy plastic and secured with tape. The body was surprisingly well preserved even though the remains had been buried for almost five years before exhumation. This contrasts with another case observed by Manhein (1997) where a young female had been wrapped in a polyester mattress cover while wearing clothing. Her remains were completely skeletonized and had been buried for at least eight years before being found. A third case observed a man found buried in a shallow grave (18 inches) who had been missing for almost four months. The man had been missing throughout the winter and, when found, was clothed in a warm-up suit, bound, and wrapped in a vinyl tablecloth 
(Manhein, 1997). Other than the areas that were exposed through the surface, the body was well preserved.

\section{Buried Remains}

Buried remains are observed to decompose in a different manner from remains that are placed on the ground surface (Burns, 2016; Carter, Yellowlees, \& Tibbett, 2010; Dix \& Graham, 2000; Haglund \& Sorg, 2002; Mann et al., 1990; Pickering \& Bachman, 2009; Rodriguez \& Bass, 1985). Mann et al. (1990) states that human remains on the ground surface tend to decay much more rapidly than remains that are buried. Temperatures and weather conditions above ground are generally higher and more damaging to the tissues (Dautartas, 2009; Janaway, 1996). Burial depth also plays an integral role in the decomposition process. Mann et al. (1990) found that remains buried at a shallow depth (1-2 ft) at the ARF at the University of Tennessee, Knoxville, skeletonized after a few months, while those buried at 3-4 $\mathrm{ft}$ took up to several years to completely decompose. It was also observed, as previously noted, that bodies which are wrapped before being buried prevent increased insect activity, thereby inhibiting the amount of decomposition that occurs.

Rodriguez and Bass (1985) came to roughly the same conclusion, and found that decomposition rates of buried cadavers were highly dependent on burial depth, as well as environmental temperatures. The shallower burials (1-2 ft) were subject to warmer temperatures, whereas those that were buried deeper within the ground $(4 \mathrm{ft})$ were subject to cooler temperatures, preserving the remains for a longer period of time (Rodriguez \& Bass, 1985). Increased burial depth, while providing more stable temperatures, also allows for further protection of the remains from insects, animal scavenging, and other destructive forces

(Dautartas, 2009; Mant, 1987). Carter et al. (2010) states that soil moisture can also affect the 
decomposition process of buried remains. They found that moist soil reduces the amount of decomposition, leading to an increase in adipocere formation, whereas dry soil leads to desiccation.

\section{Soil pH}

Soil types vary geographically based on mineral content, plant composition (tilled, forested, bog/marsh, etc.), water content, climate, and weather. Soil also varies by depth depending on geological history and mineral content (i.e., clay, loess, sand, permafrost) (Haslam \& Tibbett, 2009; Hopkins, Wiltshire, \& Turner, 2000; Rodriguez \& Bass, 1985; Vass, Bass, Wolt, Foss, \& Ammons, 1992; Wilson et al., 2007). Soils, therefore, can have a wide range of $\mathrm{pH}$ values (acidic, neutral, and alkaline), which can influence how remains may decompose over time. In the study by Haslam and Tibbett (2009), soil type had a considerable effect of the decomposition rates of skeletal muscle tissue when remains were buried. The results of the study found that the rate of decomposition was up to three times higher in acidic soil $(\mathrm{pH}<7)$ compared to alkaline soil ( $\mathrm{pH}>7)$.

Interments can alter the soil $\mathrm{pH}$. The decompositional fluids of interred sheep (Ovis aries) were observed to cause the surrounding soils $\mathrm{pH}$ to change from alkaline to acidic (Haslam \& Tibbett, 2009). It is believed that the change is due to decompositional fluids impacting the microbial community in the soil.

Rodriguez and Bass (1985) took soil samples to determine changes in soil pH before burying human cadavers at various depths $(1,2$ and $4 \mathrm{ft})$ in the ground. After exhumation, another series soil of samples were tested for change in $\mathrm{pH}$ values. These samples were taken at the base of each burial trench, as well as a little over an inch above each cadaver. Their results indicate that all the burial graves were found to increase alkalinity. Evidently, soil pH increased 
in alkalinity during the bloated and active decomposition stages and began to level off at the dry stage of decomposition (Rodriguez \& Bass, 1985).

\section{Cold Weather Studies}

Cold weather environments are regions where ambient temperatures (daytime or nighttime) reach below freezing $\left(32^{\circ} \mathrm{F} / 0^{\circ} \mathrm{C}\right)$, while also experiencing precipitation (i.e., snow, ice, sleet, etc.) associated with these temperatures. Cold weather precipitation can influence decomposition rates and processes by blanketing the surface, generating a frost zone, and varying the amount of liquid moisture that percolates into the ground. It is widely accepted that human remains decompose at a much slower rate when exposed to cold temperatures compared to remains left exposed to hotter/more arid or temperate environments (Dix \& Graham, 2000; Haglund \& Sorg, 1997, 2002; Hayman \& Oxenham, 2016; Mann et al., 1990). However, human decomposition has not been systematically studied in cold weather areas, providing little insight into how cold temperatures and weather conditions actually alter the decomposition process. The majority of studies that have been conducted examined remains that began the study as frozen samples and assessed during the thawing process (Micozzi, 1986; Roberts \& Dabbs, 2015; Zugibe \& Costello, 1993). Other relevant studies have garnered somewhat inconclusive results (Bunch, 2009) or used previously collected data (i.e., autopsy reports) to reach their conclusions (Komar, 1998). While these studies provide valuable information regarding decomposition in cold weather environments, more information is needed to accurately assess the postmortem interval in human remains.

\section{Micozzi (1986)}

The study conducted by Marc S. Micozzi compared how frozen and never frozen rats decomposed over a period of six days. Eight rats in total were used for this purpose, with four 
being frozen at $19.4^{\circ} \mathrm{F}\left(-7^{\circ} \mathrm{C}\right)$ for four weeks and then allowed to thaw at room temperature for 8 hours before field placement. Four additional rats were killed only two hours prior to field placement. Throughout the study, it was observed that frozen-thawed rats were more susceptible to insect activity and microorganisms invading from the external surface of the specimens, as well as aerobic decay of the skin. Interestingly, the fresh-killed rats experienced less external decay than the frozen-thawed specimens, but putrefaction and internal cellular breakdown did occur much more rapidly. The results showed that frozen-thawed rats postmortem decomposition proceeds from the "outside-in," whereas fresh-killed rats decomposed from the "inside-out" (Micozzi, 1986).

\section{Roberts and Dabbs (2015)}

Essentially the same conclusion as Micozzi (1986) was reached by a study undertaken by Lindsey G. Roberts and Gretchen R. Dabbs. Instead of rats, adult domestic pig carcasses (Sus scrofa) were used as human cadaver proxies to assess if frozen subjects could be used in taphonomic research. Their study was conducted at the Complex for Forensic Anthropology Research (CFAR) at Southern Illinois University. Sixteen pigs in total were used, with half being frozen $\left(-4^{\circ} \mathrm{F} /-18^{\circ} \mathrm{C}\right)$ and the other half fresh-killed. Fresh-killed pigs exhibited the expected "normal," internal, and external decomposition. In comparison, frozen pigs exhibited a decrease in putrefaction and less internal decomposition. The external surface was also affected from being previously frozen, with the surface becoming weakened and dehydrated. This likely caused the increase in desiccation, insect activity, and overall gray discoloration. Roberts and Dabbs (2015) concluded that previously frozen subjects do not accurately reflect the "normal" variations of decomposition and should not be used for taphonomic research. Their results 
aligned with Micozzi's (1986) assessment that frozen subjects decomposed from the "outsidein," while normal decomposition proceeds from the "inside-out."

\section{Zugibe and Costello (1993)}

Frederick T. Zugibe and James T. Costello autopsied the remains of a murder victim that had been intentionally frozen for two and a quarter years prior to being found alongside a mountain road. The body appeared to be markedly decomposed without any evidence of distention or bloating. The surface of the body appeared to be greasy in consistency with significantly less decomposition internally than externally. There was no visible distention of the abdomen and the subject's internal viscera were well preserved. The peculiar decomposition pattern suggested that the victim may have been frozen for a period of time prior to being found and supports the findings of Micozzi (1986) and Roberts and Dabbs (2015).

\section{Bunch (2009)}

Ann W. Bunch conducted a qualitative study on three pigs (Sus scrofa) at the Rice Creek Field Station outside the State University of New York at Oswego. The climate in this area is characterized by cold winters with regular snowfall. Each specimen used within the study weighed between 35-40 pounds, and were placed in three separate microclimates (sparse hardwood forest near a water source [1], dense hardwood forest [2], and spruce forest [3]) inside enclosures to prevent carnivore scavenging. The states of decomposition were categorized as fresh, discoloration, bloating, skeletonized, and skeletal decomposition (Bunch 2009). Results obtained were varying in degrees of decomposition between the three specimens. The specimen with the most advanced decomposition (specimen \#3) reached skeletonization after one year of exposure. Specimen \#3 was placed on the ground surface in a spruce forest. This microenvironment had little direct sunlight, less overall insect activity, and the soil was slightly 
acidic ( $\mathrm{pH}$ of 5.5). It is unknown exactly why specimen \#3 reached skeletonization after such a short period of time. The final results of Bunch's study show that pig specimens (Sus scrofa) express a slower rate of decomposition when exposed to a lower overall ambient temperature (Bunch, 2009; Haglund \& Sorg, 2002; Mann et al., 1990).

\section{Komar (1998)}

Multiple cases of advanced decomposition from the Medical Examiner's office in Edmonton, Alberta were examined by Debra A. Komar. The climatological context of Edmonton experiences consistently below freezing daily temperatures for at least five months of the year (Cheng, Fu, Angle, \& Sandhu, 1997; Hage, 1972; Komar, 1998; Wang, 2005) allowing exposed human remains to come in contact with these colder temperatures for extended portions of the year. The goal of Komar's study was to establish a methodological framework for future research conducted in cold climates. Twenty human cases submitted to the ME's office were recovered in varying states of decomposition and from a variety of post-depositional environments. Stages of decomposition were recorded for each individual during their autopsy. These stages of decomposition included moderate decomposition, advanced decomposition, partial skeletonization, and complete skeletonization. Results indicate that in the summer months, remains could become skeletonized in less than six weeks. However, decomposition slowed dramatically during the winter months with one case reaching skeletonization in four months with temperatures around $-7.1^{\circ} \mathrm{C}\left(19.2^{\circ} \mathrm{F}\right)$.

\section{Central Illinois Weather Trends}

The current research builds from these previous studies in order to create a more accurate representation of the PMI in cold weather environments. Central Illinois provides a unique environment to study the decompositional effects of cold temperatures and weather condition on 
pig proxies. According to U.S. Climate Data, the average snowfall in central Illinois is $\sim 20-25$ inches annually. The average high temperature for January-May are $33^{\circ} \mathrm{F} / 0.5^{\circ} \mathrm{C}$ in January, $38^{\circ} \mathrm{F} / 3^{\circ} \mathrm{C}$ in February, $49^{\circ} \mathrm{F} / 9^{\circ} \mathrm{C}$ in March, $62^{\circ} \mathrm{F} / 17^{\circ} \mathrm{C}$ in April, and $73^{\circ} \mathrm{F} / 23^{\circ} \mathrm{C}$ in May. The average low temperature for the same period is $15^{\circ} \mathrm{F} /-9^{\circ} \mathrm{C}$ in January, $18^{\circ} \mathrm{F} /-8^{\circ} \mathrm{C}$ in February, $27^{\circ} \mathrm{F} / 3^{\circ} \mathrm{C}$ in March, $38^{\circ} \mathrm{F} / 3^{\circ} \mathrm{C}$ in April, and $49^{\circ} \mathrm{F} / 9^{\circ} \mathrm{C}$ in May (Table 1 ). However, the temperature results for the current study differ slightly from temperature gathered from the U.S. climate data (Table 1). The preservative effects of cold temperatures allow for remains to appear fresh or as in the early stages of decomposition when, in reality, the PMI may be prolonged. This study aids in providing a more accurate assessment of the PMI in an environment such as central Illinois, so that death investigators have a method of estimating the PMI that is more conclusive in cold weather settings.

Table 2

Average High and Low Temperature Readings in Normal, IL

\begin{tabular}{|c|c|c|c|c|c|}
\hline \multicolumn{5}{|c|}{ AVERAGE TEMPERATURE READINGS IN NORMAL, IL } \\
\hline & Jan. & Feb. & March & April & May \\
\hline High Temperature $\left({ }^{\circ} \mathrm{F} /{ }^{\circ} \mathrm{C}\right)$ & $33 / 0.5$ & $38 / 3.3$ & $49 / 9.4$ & $62 / 16.7$ & $73 / 22.8$ \\
\hline Low Temperature $\left({ }^{\circ} \mathrm{F} /{ }^{\circ} \mathrm{C}\right)$ & $15 /-9.4$ & $18 /-7.8$ & $27 /-2.8$ & $38 / 3.3$ & $49 / 9.4$ \\
\hline \multicolumn{7}{|c|}{ PRESENT STUDY'S TEMPERATURE RESULTS (2018) } \\
\hline High Temperature $\left({ }^{\circ} \mathrm{F} /{ }^{\circ} \mathrm{C}\right)$ & $39 / 3.9$ & $38 / 3.3$ & $46 / 7.8$ & $53 / 11.7$ & $80 / 26.7$ \\
\hline Cold Temperature $\left({ }^{\circ} \mathrm{F} /{ }^{\circ} \mathrm{C}\right)$ & $24 /-4.4$ & $24 /-4.4$ & $40 / 4.4$ & $35 / 1.7$ & $57 / 13.9$ \\
\hline
\end{tabular}




\section{CHAPTER III: MATERIALS AND METHODS}

In order to analyze the decompositional variations experienced by partial pig samples in cold weather settings, a well-defined and controlled research area was constructed to contain and protect the ten test subjects (A, B, C, D, E, F, G, H, I, and J). The research area was visited daily to observe any qualitative changes that may have occurred to the specimens placed on the ground surface. Extensive notes and photographs were taken each day, over the course of more than four months, along with the daily weather conditions (i.e., temperature, humidity, wind speed). At the two- month interval, half of the pig specimens, including a surface specimen, were unearthed and information was recorded and photographed at these times. This was repeated for the remaining half of the test subjects at four months. Temperatures and conditions were gathered from the US Weather Service for the town of Normal, Illinois as reported by the televised media (The Weather Channel [TWC]).

\section{Site Construction}

The research project was conducted in Normal, Illinois approximately 3.1 miles north of the Illinois State University campus $\left(40.51076^{\circ} \mathrm{N} 88.99346^{\circ} \mathrm{W}\right)$. On January 1,2018 , the ground surface, consisting of local rock, native topsoil, and plant material was cleared to expose an area of bare soil measuring 120"x 36". A rectangular trench was dug which would inter eight of the specimens (A-H). To dig the trench, a pick axe, a spade shovel, a square shovel, and a round nose shovel were used. The topsoil was loosened using the pick axe, then, the shovels were used to dig out the remaining soil from the trench. The air temperature on this day was $-3^{\circ} \mathrm{F}\left(-19^{\circ} \mathrm{C}\right)$, and it took nearly two hours for the trench to be completed due to the ground being frozen. The measurement of the trench, when completed, was 72"x 20"x 18" (Figure $1 \&$ Figure 2). 


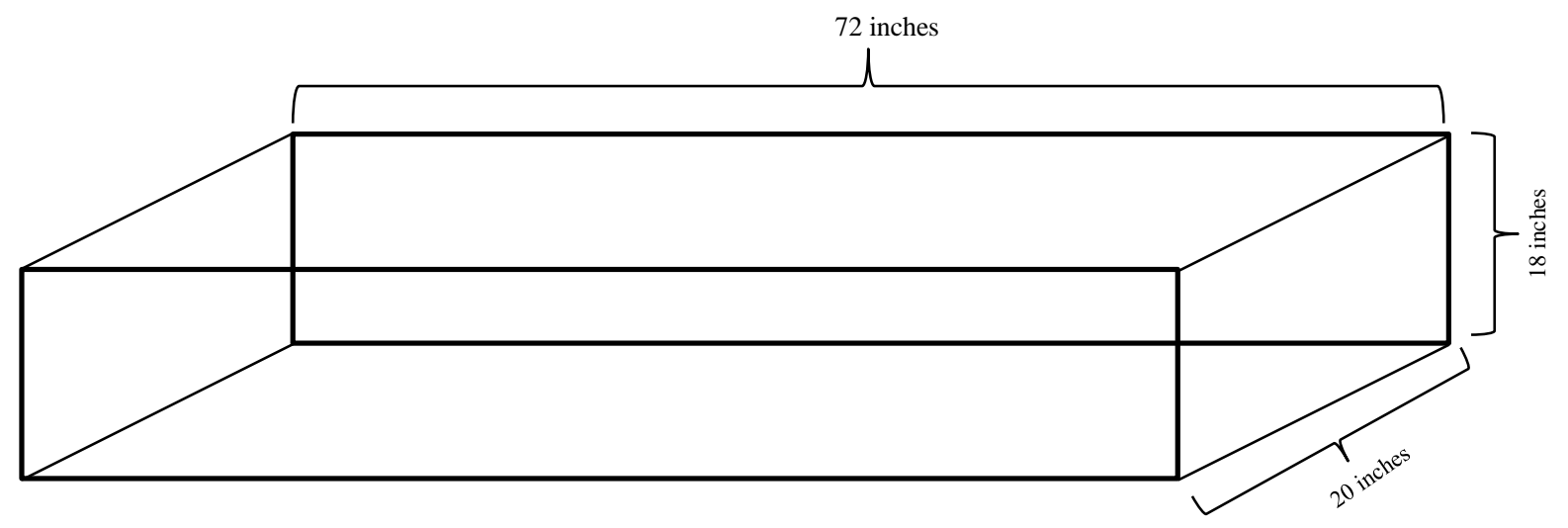

Figure 1. Completed dimensions of the trench constructed to house the buried specimens.

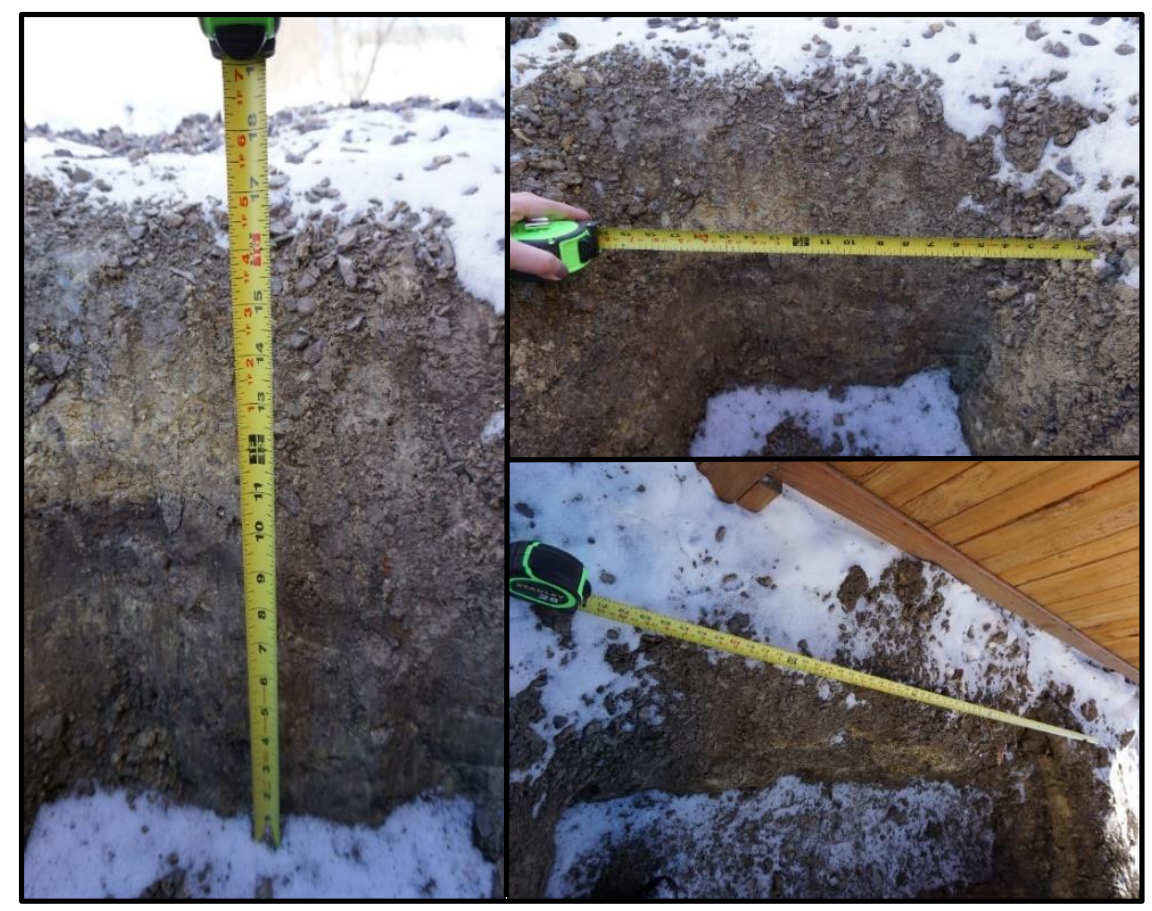

Figure 2. Measurements of depth, width, and length taken after completion of the trench.

Two soil samples were collected from depths of 6 inches (Figure 3) and 18 inches. These depths represent the areas where the specimens would be buried within the earth. While the trench was being dug, it was observed that at roughly four inches the topsoil began to turn to a 
layer of clay. The layer of clay measured about two inches thick and below this layer black soil continued for only another two inches before clay was observed again. Below the layer of clay, a mixture of black soil and clay were observed until the trench ceased construction at 18 inches in depth. The soil samples were placed in plastic bags and were sent to A\&L Great Lakes Laboratories to determine the soil $\mathrm{pH}$, along with other soil properties which may affect the decomposition process. Photographs were taken to document the soil stratigraphy, soil depth, and overall layout of the constructed trench (Figure $4 \mathrm{a} \& 4 \mathrm{~b}$ ). Directly south of the study area is a wooden fence panel that stands approximately 72 inches in height.

Next to the trench, there was an additional area (36"x 36") where the ground surface specimens (I and J) would be placed. This space was cleared in order to be consistent with the area that had already been cleared, and to determine how the soil surface might affect the specimens placed in this area.

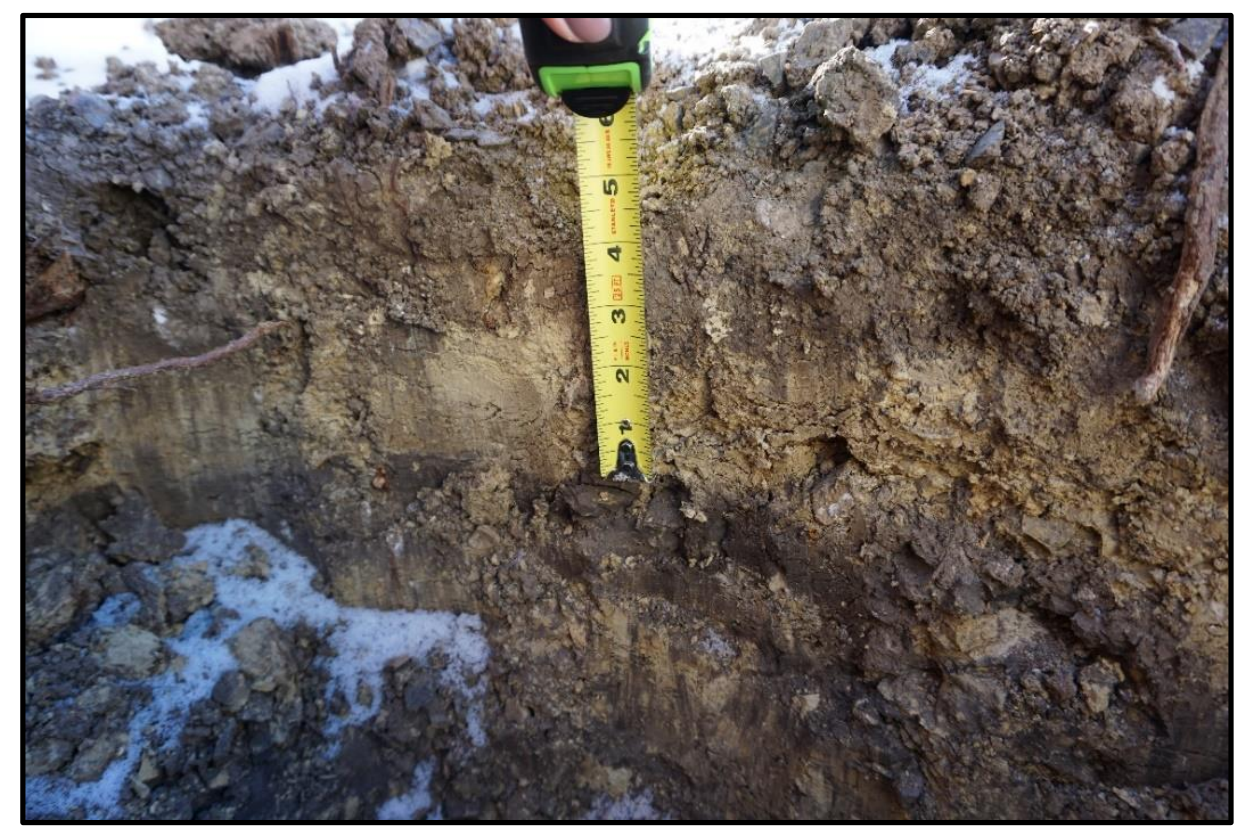

Figure 3. Soil sample taken from approximately 6 inches below the soil surface. 


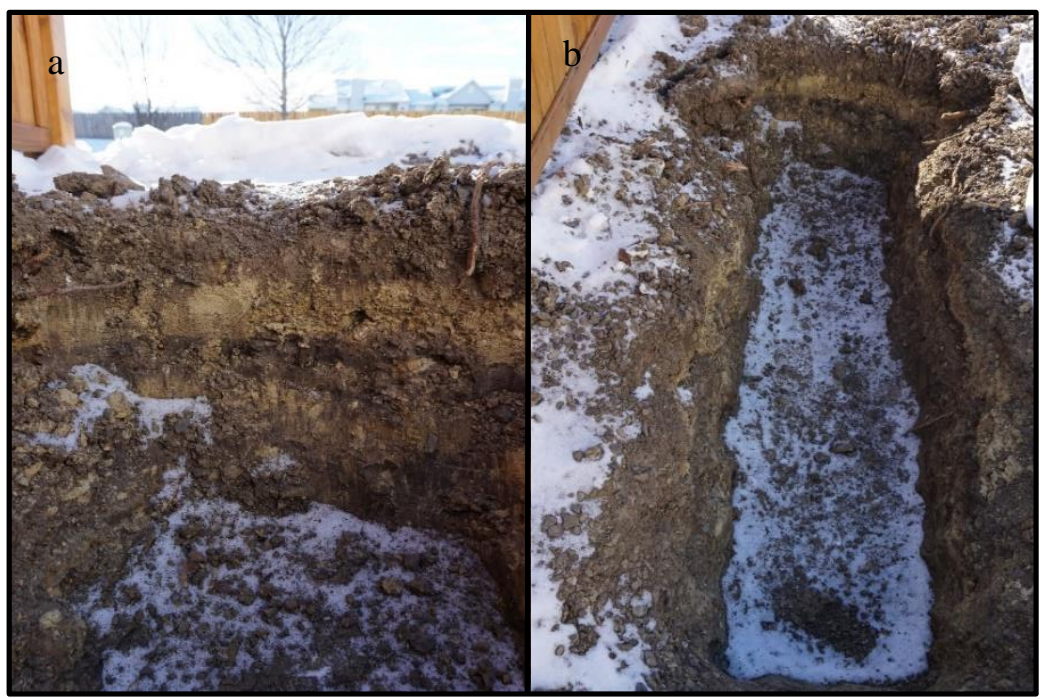

Figure 4. Stratigraphy and layout of the trench: a) Soil stratigraphy after the trench was completed; b) Layout of the constructed trench.

\section{Site Security}

In order to deter animals and scavenging activity, each specimen was placed within a metal-wire cage. Those specimens placed beneath the ground were paired, so there would be two specimens in each cage at depths of 6 inches and 18 inches. A total of four metal-wire cages were placed within the trench previously constructed (Figure 5). Each of the four cages measured 18 "x 12"x 14" and were placed side by side within the trench (Figure 6).

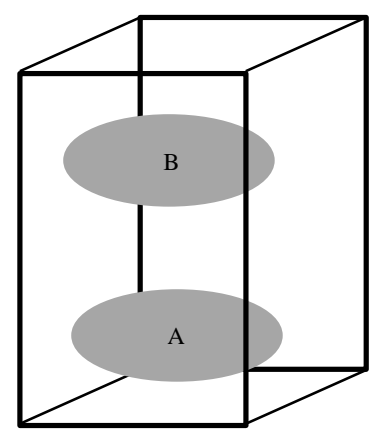

Cage 1

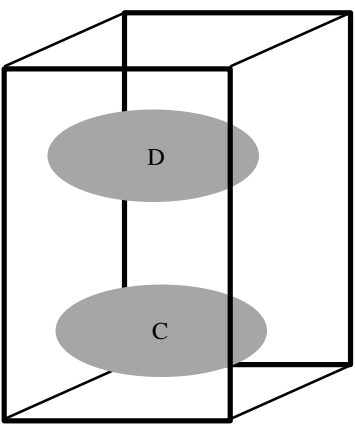

Cage 2

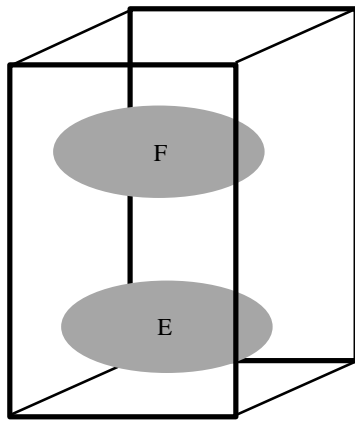

Cage 3

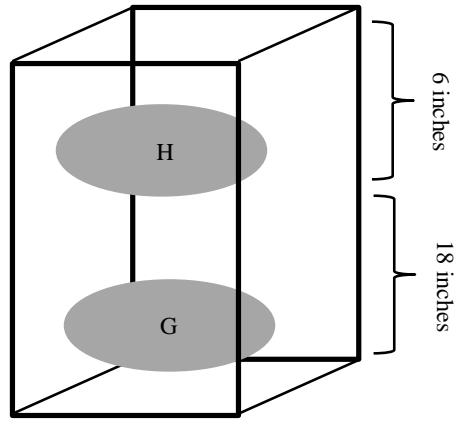

Cage 4

Figure 5. Placement of each specimen at depths of 6 and 18 inches in cages 1-4. 


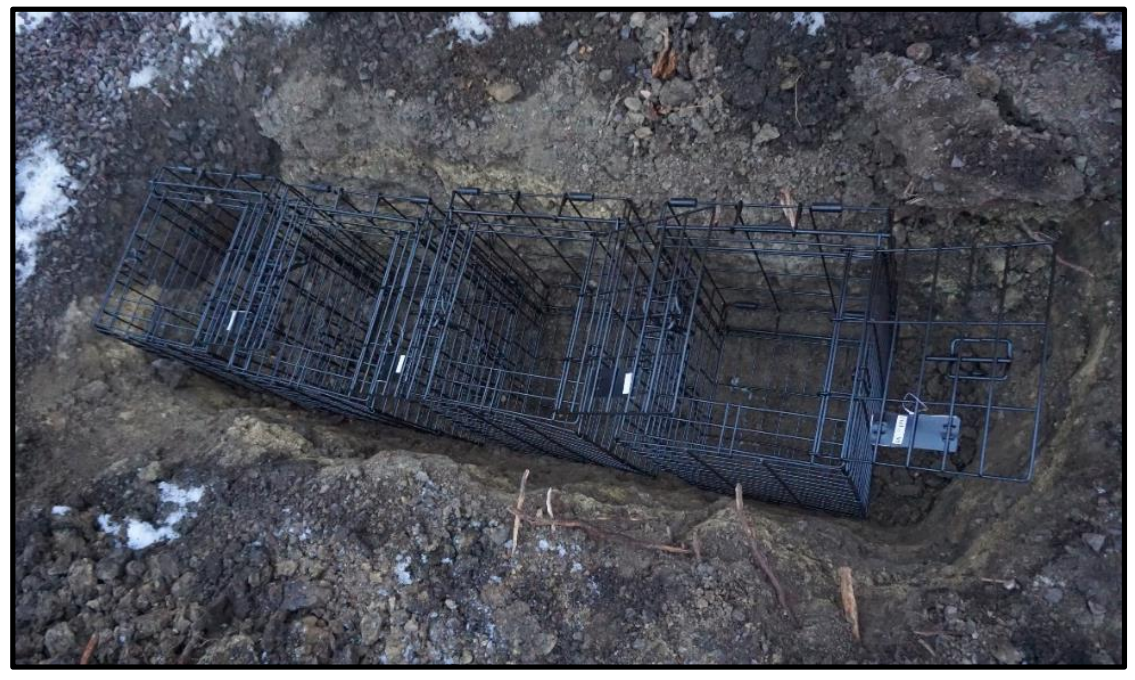

Figure 6. Cages 1-4 (18"x12"x14”) within the constructed trench.

The cage (cage 5) that housed the uncovered surface specimens was specially constructed for this project. The materials that comprised this cage included square metal chicken wire, metal rebar (e.g., large metal stakes), flexible metal wire, and plastic zip ties. The metal rebar was bent to create a, partial, square shape. Then, the chicken wire was form-fitted over the rebar posts and it was all held together by the metal wire and zip ties. There was also a bottom portion to this cage, which was solely made out of chicken wire formed into the shape of a square with sides. This bottom section was constructed so that animals would not be able to dig underneath the surface specimens. The dimensions of the entire cage were 24 " x 24 ”x 12 ".

\section{Specimens}

Partial pig specimens (Sus scrofa) were used as proxies for human remains. Pigs are often used as substitutes for human cadavers because their biological characteristics are markedly similar one another. The specimens used in this research consisted of the hind legs of pigs, which were cut into thirds. The similarities between these partial pig specimens and human cadavers, 
would be if the human remains had previously been dismembered before disposal. The pig remains each consisted of bone, muscle, fat, and skin.

Four hind legs of Sus scrofa were acquired from College Hills Meat Shop in Normal, Illinois on January $9^{\text {th }}, 2018$. The order for the test subjects had been made one week prior to their retrieval from College Hills Meat Shop, but they were not actually available until January $9^{\text {th }}$ at 10:00am. The exact day or time of death of the pigs is uncertain, but the specimens had not been frozen prior to the start of this study. At the butcher, each of the four hind limbs were cut into thirds. There was a total of twelve partial portions of the hind legs, but only ten of these portions would be used as a part of this study. It was made certain that each of the thirds retained bone, muscle, fat, and skin, so that they would be as similar to one another as possible.

Table 3

Weight and Circumference of Each Specimen (A-J) Taken on January 9, 2018

\begin{tabular}{c|c|c|c|c|c|c|c|c|c|c}
\hline & \multicolumn{10}{c}{ SPECIMENS (JANUARY 9 9018) } \\
\hline & $\mathrm{A}$ & $\mathrm{B}$ & $\mathrm{C}$ & $\mathrm{D}$ & $\mathrm{E}$ & $\mathrm{F}$ & $\mathrm{G}$ & $\mathrm{H}$ & $\mathrm{I}$ & $\mathrm{J}$ \\
\hline $\begin{array}{c}\text { WEIGHT } \\
\text { (POUNDS): }\end{array}$ & 7.2 & 6.6 & 10.0 & 9.8 & 9.4 & 9.0 & 8.6 & 8.4 & 7.8 & 7.8 \\
\hline $\begin{array}{c}\text { CIRCUMFERENCE } \\
\text { (INCHES): }\end{array}$ & 26.5 & 27.5 & 27.0 & 26.5 & 18.0 & 17.0 & 17.0 & 18.5 & 30.5 & 31.0 \\
\hline
\end{tabular}

The specimens were measured and weighed prior to their placement in the ground (Table 3). The specimens were measured using a garment tape measure around their widest point to determine the overall circumference. In order to weigh the specimens, they were placed on a Sharper Image Precision Digital Food Scale. Each of the ten specimens were labeled A-J. Each specimen was also photographed prior to being wrapped in clothing (Figure 7a, 7b, 7c, \&7d) or wrapped in a plastic garbage bag (Figure 8a, 8b, 8c, \& 8d). 


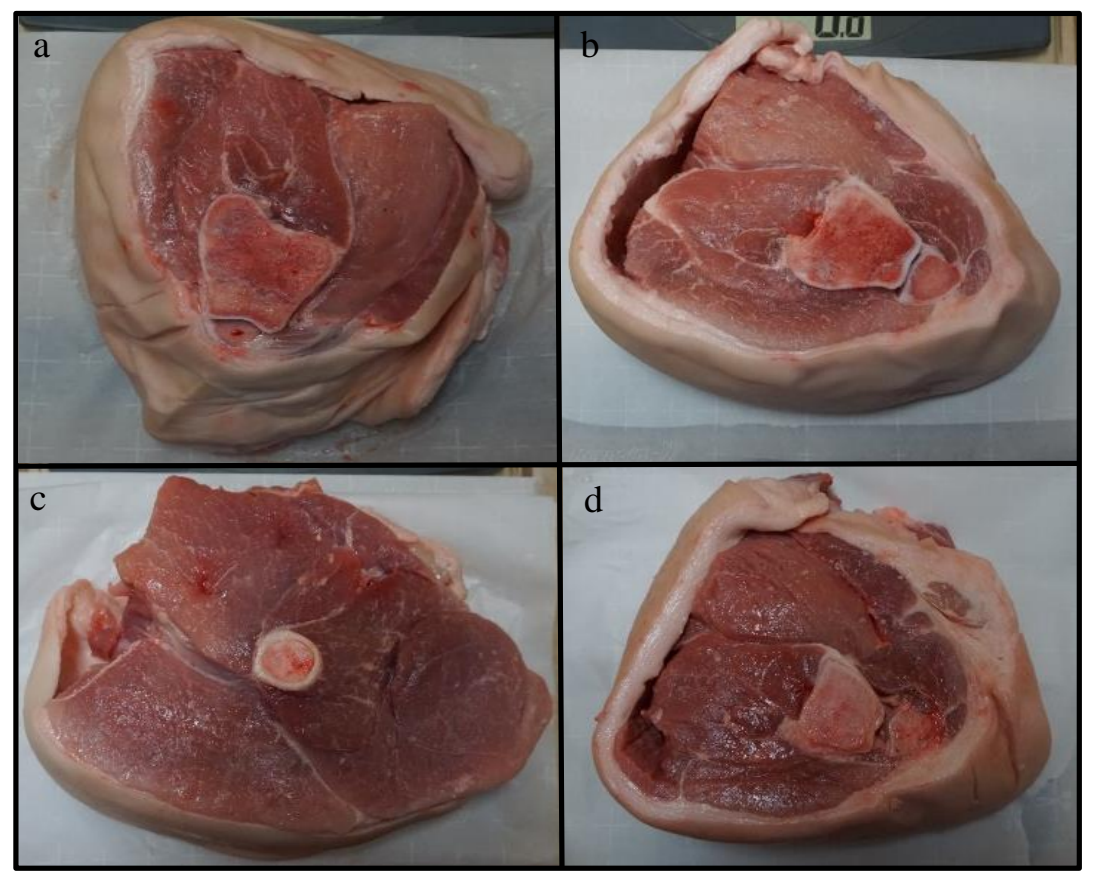

Figure 7. Clothed specimens before field placement: a) Specimen A; b) Specimen B; c) Specimen C;

d) Specimen D.

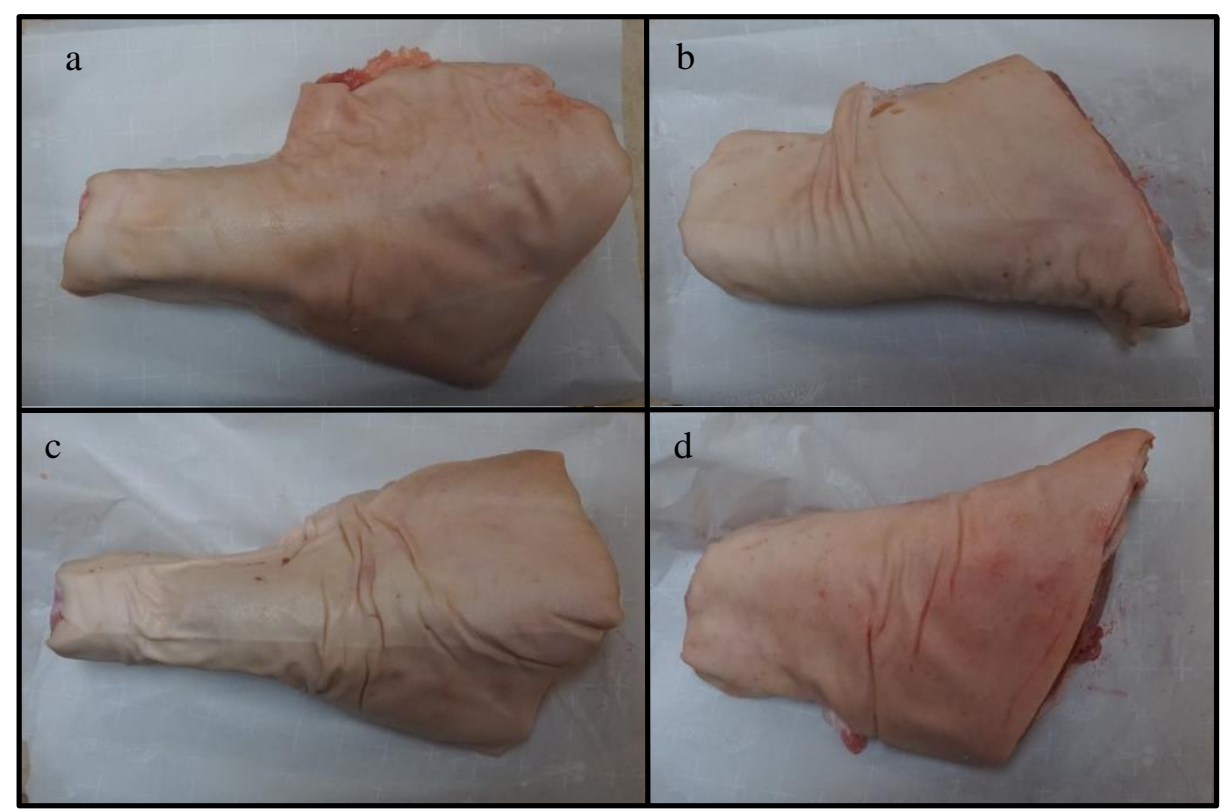

Figure 8. Specimens before being wrapped in garbage bags: a) Specimen E; b) Specimen F; c)

Specimen G; d) Specimen H. 
After this basic information was gathered, the specimens were wrapped in their respective coverings. Specimens A, B, C, and D were all wrapped in $100 \%$ white cotton t-shirts (Figure 9). All of the shirts were adult size small and they were wrapped identically around each of the four specimens. The pig subject was placed inside the middle of each t-shirt, then, the bottom was wrapped upward, next the top of the t-shirt was folded downward. Then the right side was folded over, and lastly, the left side was folded inward.

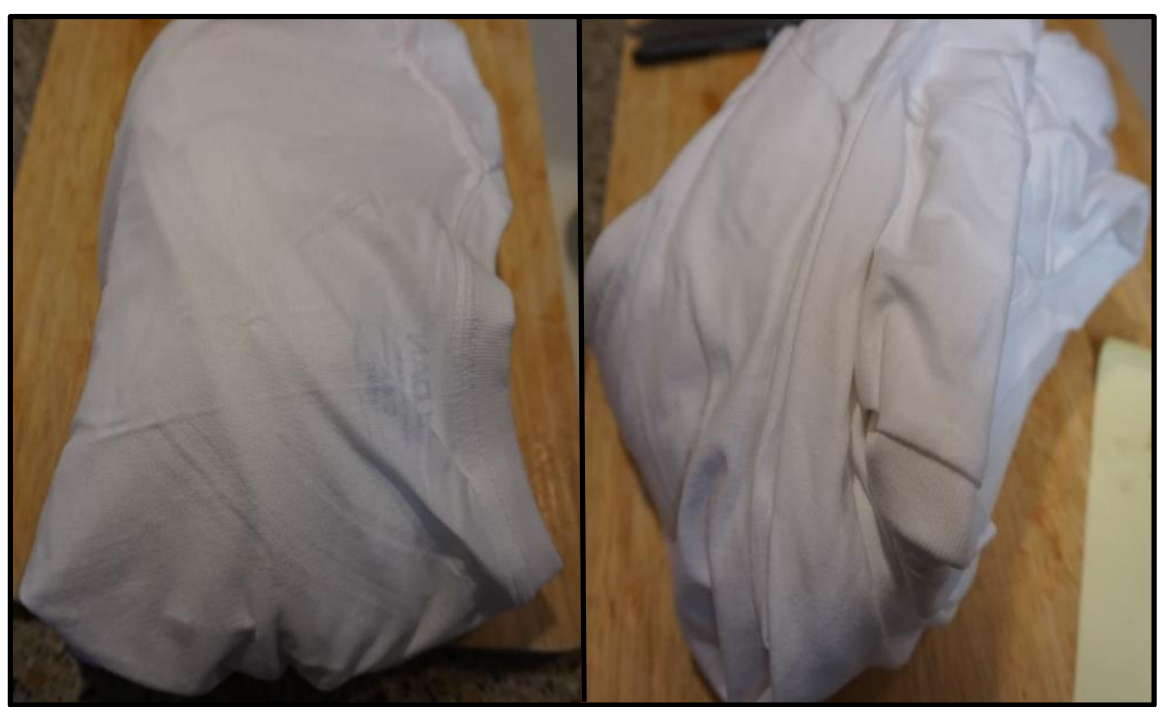

Figure 9. Example of how the white cotton t-shirts were wrapped around each specimen.

Specimens E, F, G, and H were all wrapped in separate 13-gallon plastic garbage bags (Figure 10). The dimensions of the garbage bags were: 24 inches x 24 inches. The pig specimens were placed at the bottom of their respective garbage bag, then the bag was wrapped, circularly, around the specimen, creating an airtight environment. The sides of the garbage bag were then brought inward and tucked under each specimen. Lastly, the bag was tied closed using a shoelace style knot. 


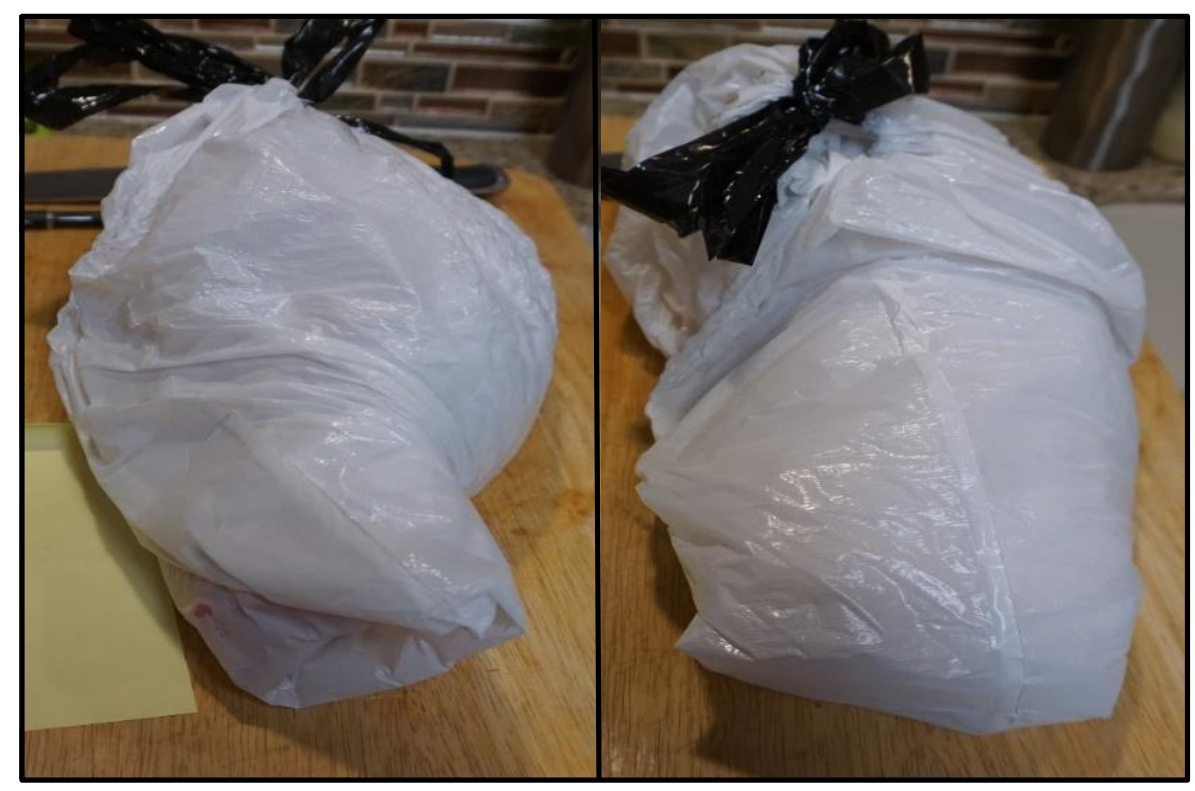

Figure 10. Example of how the plastic garbage bags were wrapped around each specimen.

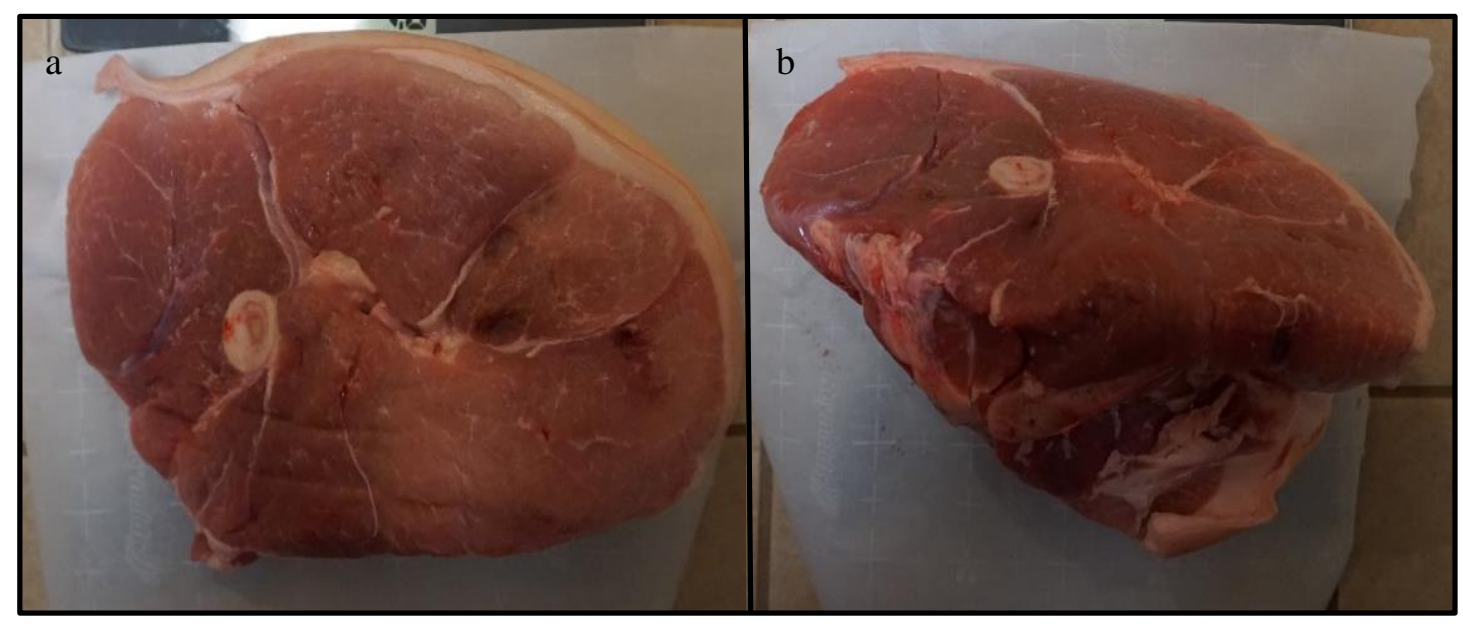

Figure 11. Specimens that would be left exposed on the ground surface before field placement: a)

Specimen I; b) Specimen J. 
It was important that the wrappings on each of the pig specimens were as identical as possible so as not to create any possible differences that could lead to decompositional variations between the specimens.

The two specimens, I and J, were placed on the ground surface without any external coverings (Figure 11a \& 11b). Other than being photographed, measured and weighed, no additional treatment was given to either of these two specimens.

\begin{tabular}{|c|c|}
\hline \multicolumn{2}{|r|}{ Stages of Decomposition } \\
\hline Fresh & $\begin{array}{ll}\text { - } & \text { Fresh appearance } \\
\text { - No discoloration } \\
\text { - No insect activity } \\
\text { - } \quad \text { Fresh burned/Freezer burned }\end{array}$ \\
\hline Early Decomposition & $\begin{array}{l}\text { - } \text { Pink-white appearance with skin slippage } \\
\text { - Gray (muted) to green discoloration, some flesh } \\
\text { relatively fresh } \\
\text { - Skin having a leathery appearance }\end{array}$ \\
\hline Advanced Decomposition & $\begin{array}{l}\text { - } \text { Decomposition of tissues producing sagging of flesh } \\
\text { - Maggot and insect activity } \\
\text { - Moist decomposition in which there is bone exposure } \\
\text { - Mummification of outer tissues } \\
\text { - Mummification with bone exposure of less than one half } \\
\text { - } \text { the skeleton } \\
\text { - Adipocere development }\end{array}$ \\
\hline Skeletonization & $\begin{array}{l}\text { - Bones with greasy substances and decomposed tissue, } \\
\text { sometimes with body fluids still present } \\
\text { - Bones with desiccated tissue or mummified tissue } \\
\text { covering less that one half the skeleton } \\
\text { - Bones largely dry but still retaining some grease } \\
\text { - Dry bone }\end{array}$ \\
\hline
\end{tabular}

Figure 12. Scoring sheet for each stage of decomposition. Adapted for "Decay rates of human remains in an arid environment," by Galloway, A., Birkby, W., Jones, A. M., Henry, T. E., \& Parks, B. O., 1989, Journal of Forensic Sciences, 34(3), 607-616. 
A scoring sheet, based on the Galloway et al. (1989) study, was generated (Figure 12) to record the stages of decomposition for each partial pig specimen (Sus scrofa). These stages are: fresh, early decomposition, advanced decomposition, and skeletonization, with certain markers (i.e., changes in appearance) delineated for each stage in the decomposition process.

\section{Placement of Specimens at Test Site}

On January $9^{\text {th }}, 2018$, all of the test subjects were placed in their respective locations within the test site. Numerous photographs were taken throughout the course of the placement of these specimens within the testing area. The temperature at the time of placement ( 4:00pm), was $33^{\circ} \mathrm{F} / 0.5^{\circ} \mathrm{C}$. The four metal-wire cages placed within the constructed trench were opened and a light amount of soil was placed at the bottom of each. This was done so the subjects would not be laying directly on top of the metal. Specimen A, C, E, and G were placed in separate cages at the 18-inch depth. Specimen A was placed in cage 1, specimen C in cage 2, specimen E in cage 3 , and specimen $\mathrm{G}$ was placed in cage 4 (Figure 13a, 13b, 13c, \& 13d).

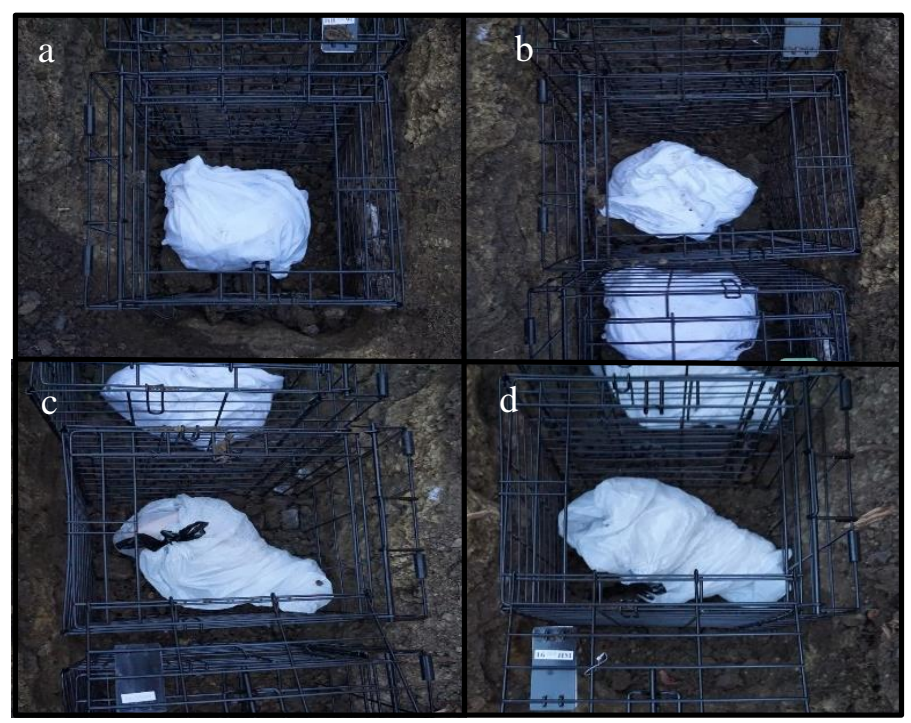

Figure 13. Specimens at 18 inches: a) Specimen A placed in cage 1; b) Specimen C placed in cage 2;

c) Specimen E placed in cage 3; d) Specimen G placed in cage 4. 
After these specimens were placed within each cage, soil was placed over them until there was a depth of 6 inches remaining. Then, specimens B, D, F, and $\mathrm{H}$ were placed within cages 1-4. These specimens were buried at a depth of 6 inches below ground level. Specimen B was placed in cage 1 , specimen $\mathrm{D}$ in cage 2 , specimen $\mathrm{F}$ in cage 3 , and specimen $\mathrm{H}$ was placed in cage 4 (Figure 14a, 14b, 14c, \& 14d). Once each of the eight specimens were placed within their cages, all of the cages were locked closed. More soil was placed over the specimens and cages until they were no longer visible. Bricks were then laid over each of the four cages to signify where the opening to each was located (Figure 15a \& 15b).

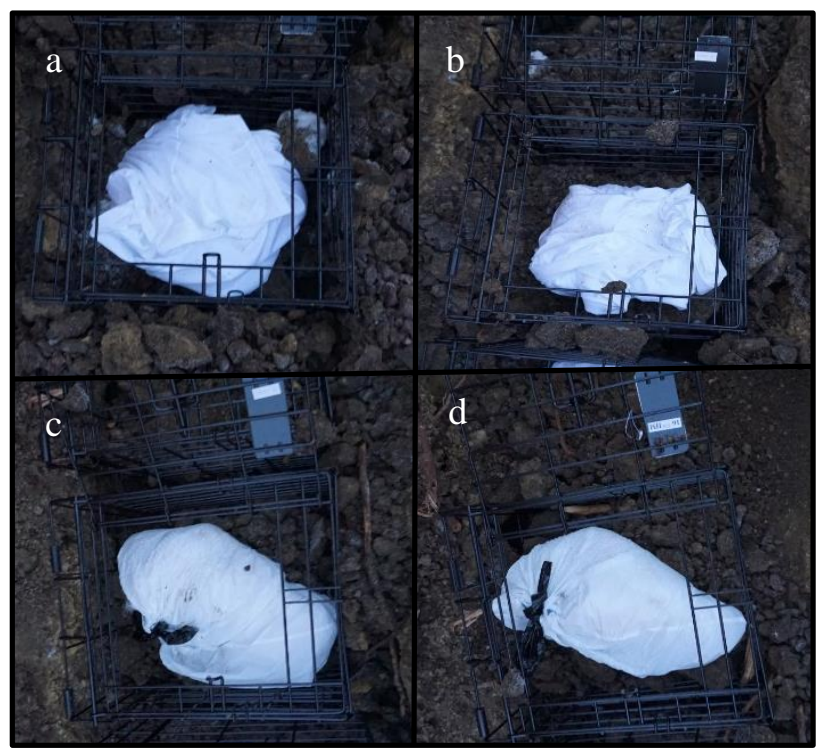

Figure 14. Specimens at 6 inches: a) specimen B in cage 1; b) specimen D in cage 2; c) specimen F in cage 3 ; d) specimen $\mathrm{H}$ in cage 4. 


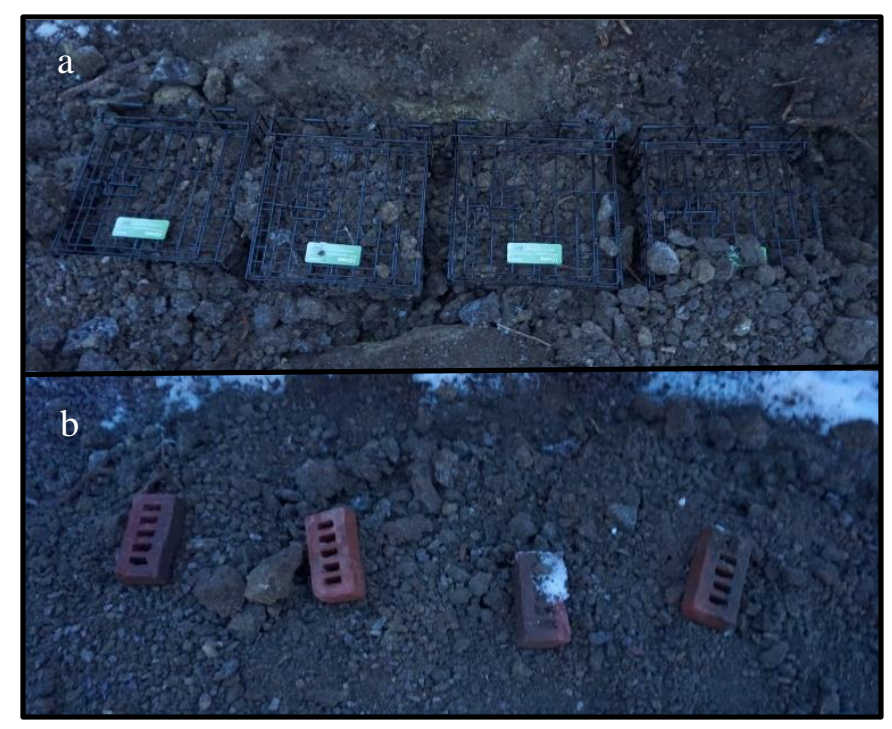

Figure 15. Buried cages completely covered: a) cages filled with specimens and soil; b) bricks signifying the placement of each cage.

The specimens wrapped in white cotton t-shirts were placed in the same cages (1 and 2). Specimens A and B were in placed in cage 1, and specimens C and D were placed in cage 2. This was repeated with the specimens wrapped in plastic garbage bags. Specimen E and F were placed in cage 3 , and specimens $\mathrm{G}$ and $\mathrm{H}$ were placed in cage 4 . This was done so that it would be easier to assess the changes to each specimen at the two and four-month intervals, as well as to create a similar environment within each of the cages.

It should be noted that the soil that was placed over each specimen consisted of the soil that had been previously dug out of the trench. The soil was a mix of black topsoil, clay, small rocks, and roots from a tree that had previously grown in the area where the trench was dug.

The specially constructed cage (cage 5) made for the ground surface specimens was assembled in two separate portions within the specified testing area. The bottom portion of the cage was laid on the ground and a shallow layer of soil was placed over the metal chicken wire base. Then, specimens I and J were placed side by side, approximately 6 inches apart from each 
other (Figure 16a). Once the specimens were placed on the ground surface, the top portion of the cage was positioned over them. In order to ensure that the cage would not move due to animal activity or harsh weather conditions, four metal stakes were hammered through the top and bottom of this cage at each corner until the stakes were deep within the earth. Lastly, four bricks were placed over the top of the cage at the corners for extra security (Figure 16b). These were the only specimens that were photographed on a daily basis due to their visibility.

There was no further disturbance of any of the specimens until they were examined at the two and four-month intervals.

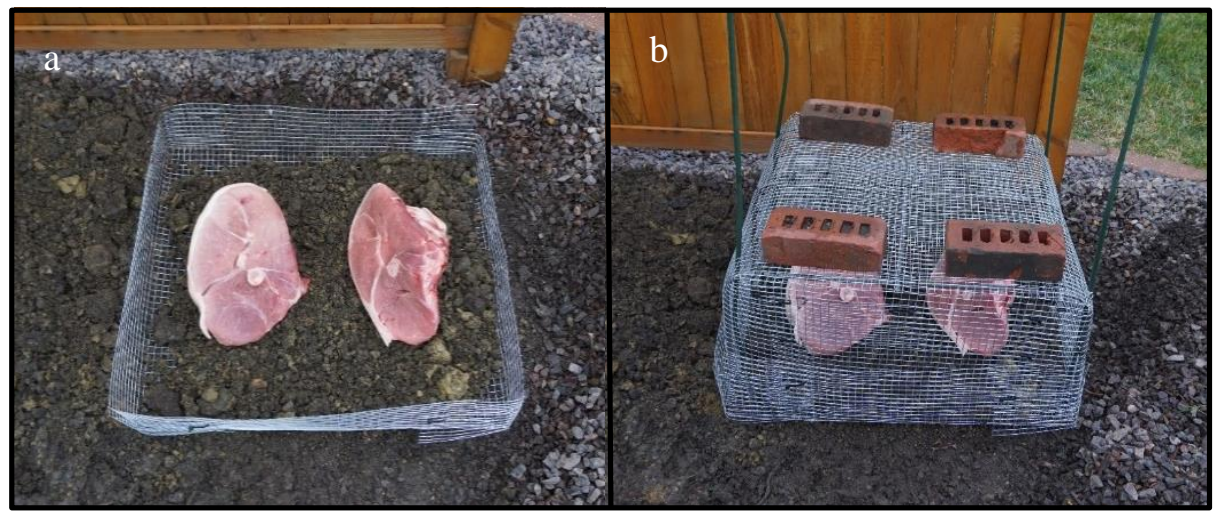

Figure 16. Construction and completion of cage 5: a) specimens I and J placed within cage 5; b)

\section{Two Months}

On March $9^{\text {th }}, 2018$, exactly two months (60 days) after the specimens had been placed at the test site, half of the pig proxies (A, B, F, E, and J) were recovered and assessed for decompositional changes. Each subject was handled with latex-gloved hands in order to not chemically affect them. All were examined at approximately 12:00pm; the temperature was $38^{\circ} \mathrm{F} / 3.3^{\circ} \mathrm{C}$. Each of the specimens was extensively photographed, weighed, and measured. Any additional notes about the specimens were recorded in a field journal. Each specimen's 
circumference was measured using a tape measure around the largest portion of the subject, and were weighed using the Sharper Image Precision Digital Food Scale. Only two flies were present during the examination of the buried subjects, but neither were present for the entire duration of each specimen.

\section{Specimen J}

This specimen had been placed in cage 5 without coverings on the ground surface. The bricks placed on top of the cage and the stakes holding the cage in place were removed in order to remove the top portion of the cage was then separated from the bottom portion to reveal specimens I and J. After observations were recorded (i.e., the score sheet) within the testing area, specimen $\mathrm{J}$ was removed from the cage and was weighed and measured.

When examination of specimen $\mathrm{J}$ had ended, the "lid" of cage 5 was placed back over the bottom portion. The stakes were again hammered through the top and bottom sections of the cage in each of the four corners and the bricks were replaced in the corners at the top of the cage. Specimen I, which was left within the cage was not handled until the four-month interval.

\section{Specimen B}

The next subject to be assessed was specimen B. This leg segment was buried in cage 1 at the 6-inch depth in a white cotton t-shirt. The brick identifying the location of cage 1 was used to define the soil removal area. The soil was raked off the top of the cage until the door keeping the cage locked was exposed. The cage was opened and a small spade was used to scrape the soil until specimen B was detected (Figure 17). Great care was taken to not damage B. 


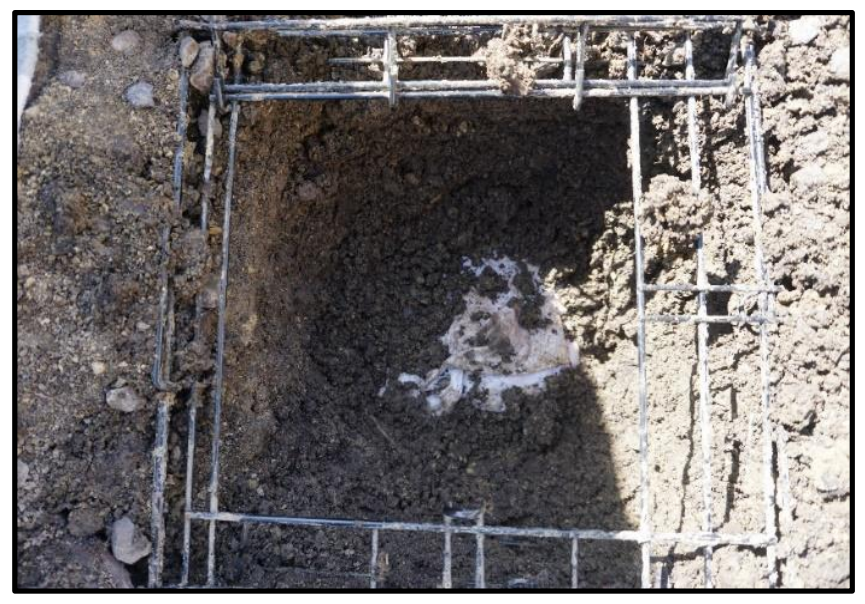

Figure 17. Top portion of specimen B visible during the two-month excavation.

When the soil was completely removed from around specimen B, it was transferred with latex-gloved hands from the cage and placed on a white plastic tarp. The t-shirt covering the specimen was carefully removed to expose the subject so it could be assessed for level of decomposition (score sheet) and weighed and measured.

\section{Specimen A}

This specimen was also covered in a white cotton t-shirt, but had been placed in Cage 1 at 18 inches below the ground. The process of uncovering and assessing specimen A was identical to that of specimen B (Figure 18). This leg segment was further decomposed than B, so the removal of the t-shirt took a greater amount of time. Due to its poor preservation, greater care also had to be taken when weighing and measuring the circumference of this subject.

After specimens A and B had both been unearthed, cage 1 was completely removed from the ground. The space which was inhabited by the cage and the two subjects was filled with soil and was no longer touched for the remaining duration of this study. 


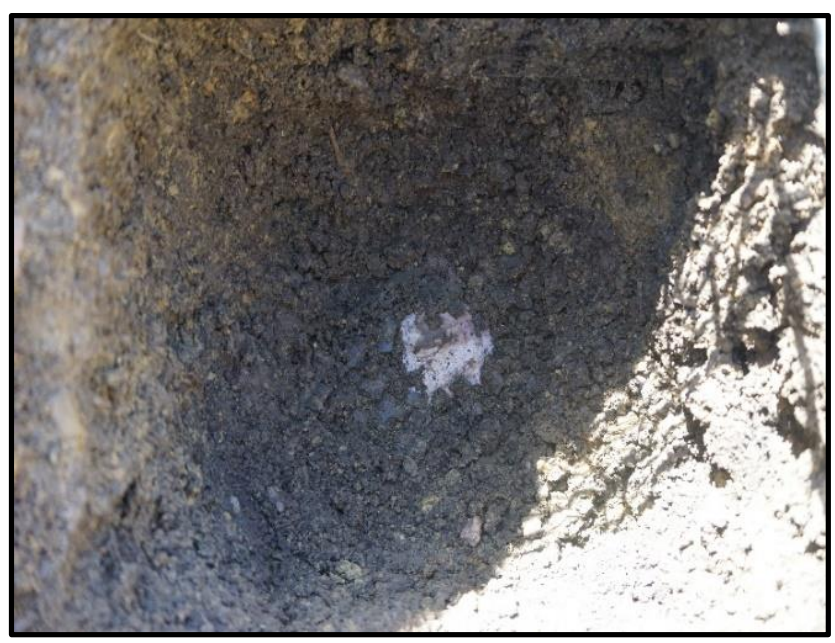

Figure 18. Top portion of specimen A visible during the two-month excavation.

\section{Specimen $\mathbf{F}$}

Specimen $\mathrm{F}$ was placed in cage 3 at the 6-inch depth and wrapped in a plastic garbage bag. $\mathrm{F}$ had been placed in cage 3 along with specimen $\mathrm{E}$. The brick that had been placed on the top of cage 3 at the beginning of this study was used to identify the recovery area. The soil was raked from the top of the cage until the door locking the cage was identified. The cage was then unlocked and opened. A small spade was used to scrape the soil above F until it was exposed (Figure 19). When the wrapped specimen was completely free from the surrounding soil, it was removed from the cage and placed on the white plastic tarp. The garbage bag was unwrapped and a medium sized hole (circa 6-inch diameter) was created near the opening of the bag to extract F. The specimen was scored, photographed, weighed, and measured. 


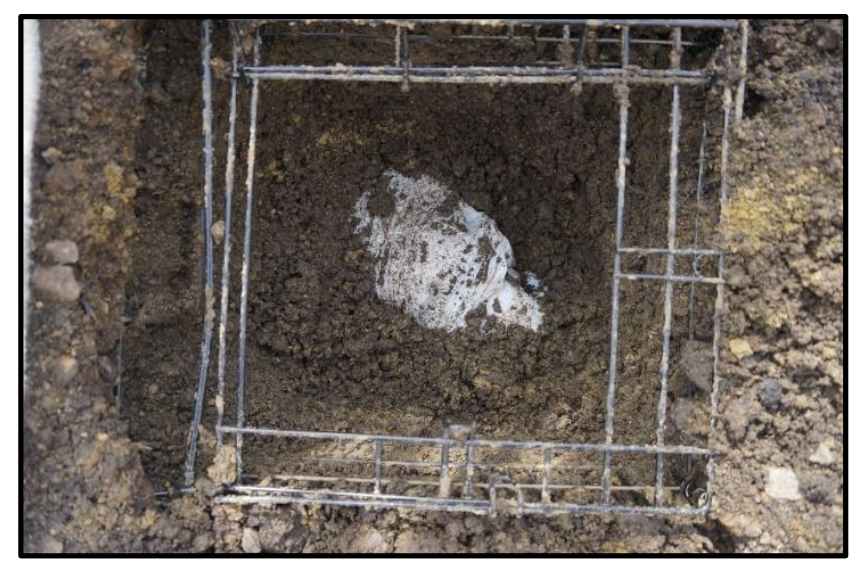

Figure 19. Top portion of specimen F during the two-month excavation.

\section{Specimen E}

This specimen had been placed in cage 3 (Figure 20) at 18 inches below the ground and it was wrapped in a white plastic garbage bag. The process of identifying and assessing specimen $\mathrm{E}$ was identical to that of specimen F.

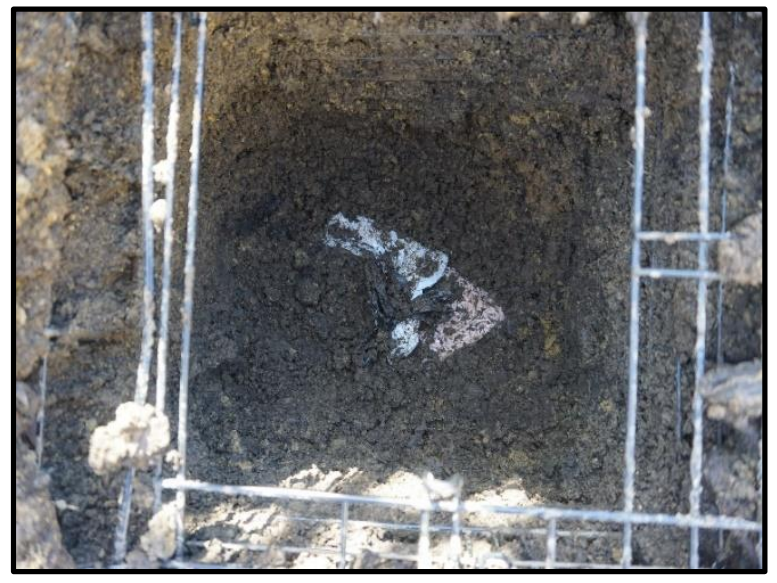

Figure 20. Top portion of specimen E excavated after two months.

When both specimen $\mathrm{E}$ and $\mathrm{F}$ were unearthed from cage 3, the cage was removed from the ground. Soil was used to fill this area and was not disturbed for the remainder of this study. 
At the end of the two-month analysis, all of the specimens that had been observed on March 9th (A, B, E, F, and J) were disposed of. They were placed in multiple garbage bags and taken to a nearby dumpster. No further analysis of these specimens would take place.

\section{Four Months}

After a four-month (123 days) period, on May $11^{\text {th }}, 2018$, the remaining specimens $(C, D$, G, H, and I) were exhumed and assessed for decompositional condition. The analysis of these specimens commenced at approximately $12: 00 \mathrm{pm}$, and the temperature on this day/time was $85^{\circ} \mathrm{F} / 29.4^{\circ} \mathrm{C}$. The methods for analyzing this group of specimens was similar to what was done at the two-month interval. Each specimen was extensively photographed, weighed, and measured. Measurements were taken by using a garment tape measure and wrapping it around the largest diameter of the specimen in order to determine the circumference. Each specimen was weighed using the Sharper Image Precision Digital Food Scale. As before, latex gloves were used when handling each subject. At this time there was also an increased presence of fly species visiting the remains as they were unearthed. Notes and photographs were taken to describe the characteristics of these flies for further examination later on.

\section{Specimen I}

This specimen was placed without coverings on the ground surface in cage 5. It was assessed first. The bricks weighing down the cage were removed, along with the stakes that had been placed through the cage into the ground. The lid of the cage was removed from the bottom section. Assessment of the decomposition stage and photographing was undertaken in situ. After the scoring, the pig segment was removed from the cage and placed on a black plastic tarp next to the study area where it could be weighed, measured, and further photographed. 
After analysis of this specimen was completed, cage 5 was removed from the test site and disposed of.

\section{Specimen D}

Specimen D in cage 2 and was the next specimen assessed. It was buried at 6 inches below the ground level and was covered in a white cotton t-shirt. The brick that had been placed over cage 2 at the beginning of this study was used to identify the cage opening. Once the door was uncovered using a small spade, the door was unlocked and opened. The same spade was used to scrape away the dirt from the cage until specimen D was reached. The dirt around the subject was completely excavated away until the subject could be taken out (Figure 21). When D was finally out of the cage, it was placed on a black plastic tarp. The specimen was photographed, assessed for decomposition level, and was able to be weighed, but had to remain wrapped in the t-shirt due to its poor preservation. No measurements could be taken due to the level of decomposition.

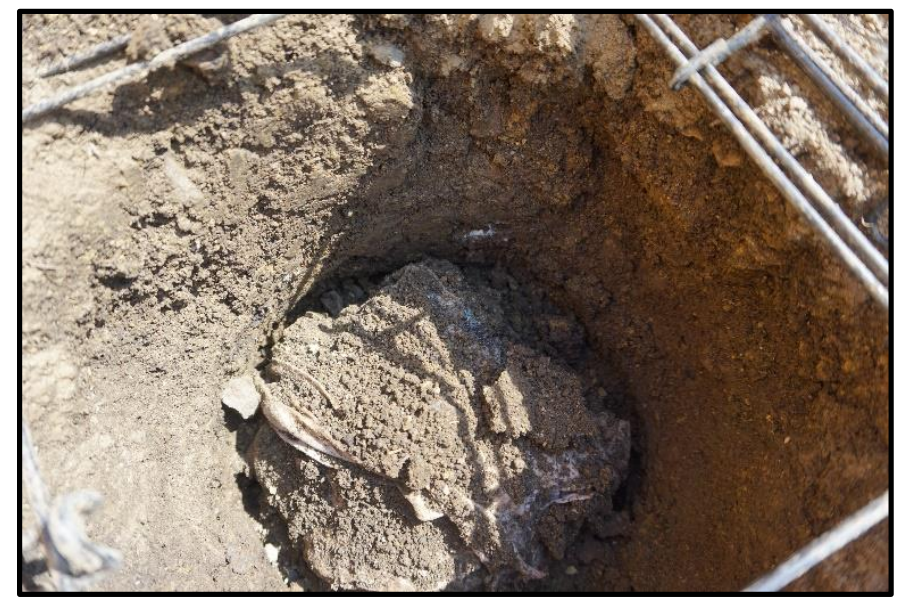

Figure 21. Top portion of specimen D excavated after four months. 


\section{Specimen C}

This specimen was placed at the 18-inch depth in cage 2 and was wrapped in a white cotton t-shirt. A small spade was used to carefully scrape away the surrounding soil until C was completely visible (Figure 22). The decomposition of this specimen was so advanced that the spade had to assist in retrieving it from the bottom of the cage. Specimen $\mathrm{C}$ was then placed on the black plastic tarp. This specimen also had to remain wrapped in the t-shirt while being weighed due to the marked decomposition. It was photographed and scored for level of decomposition. No measurements of the circumference could be taken at this time due to the incredibly poor preservation of specimen $\mathrm{C}$.

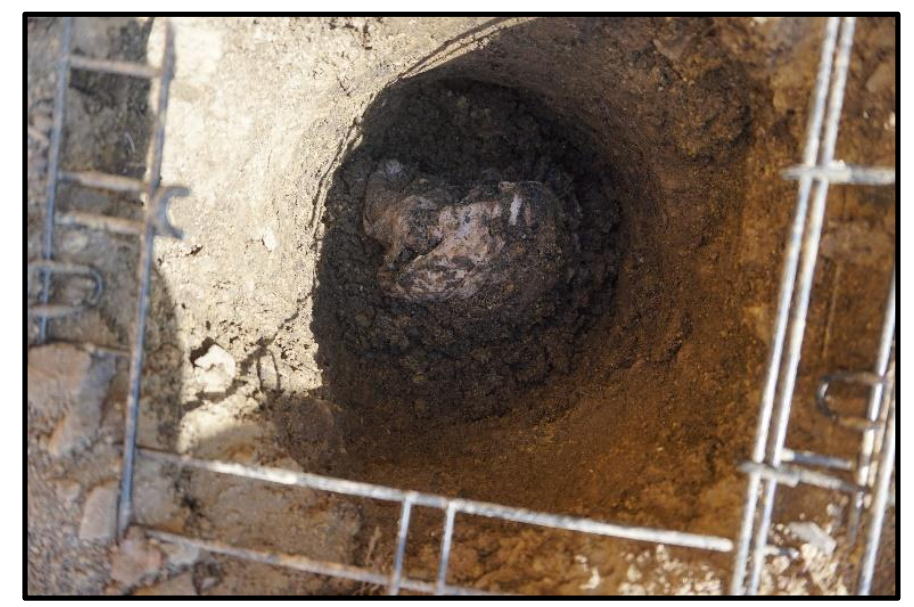

Figure 22. Top portion of specimen $\mathrm{C}$ excavated after four months.

Once specimens $\mathrm{C}$ and $\mathrm{D}$ were removed and analyzed, cage 2 was removed from the ground. Additional soil was used to fill the whole which had been occupied by cage 2, along with specimens $\mathrm{C}$ and $\mathrm{D}$. This area in which this cage and specimens were housed was no longer used for the purposed of this study. 


\section{Specimen H}

The next to be unearthed was specimen $H$. This subject had been placed at 6 inches below ground level in cage 4 , and was wrapped in a white plastic garbage bag. The brick placed over cage 4 at the beginning of the study was used to determine where the cage opening was located. Once the brick was removed, the soil was raked from the top of cage 4 until the door was identified. The door to the cage was then unlocked and opened. A small spade was used to scrape away the soil within cage 4 until specimen $\mathrm{H}$ was reached (Figure 23). The soil was then completely removed around the specimen until it was able to be taken out of the cage. It was placed on the black plastic tarp for assessment. The garbage bag enclosing $\mathrm{H}$ was opened by creating a medium sized hole (circa 6 inches) at the top of the bag. Once specimen $\mathrm{H}$ was extracted from the bag, it was scored for level of decomposition, photographed, weighed and measured.

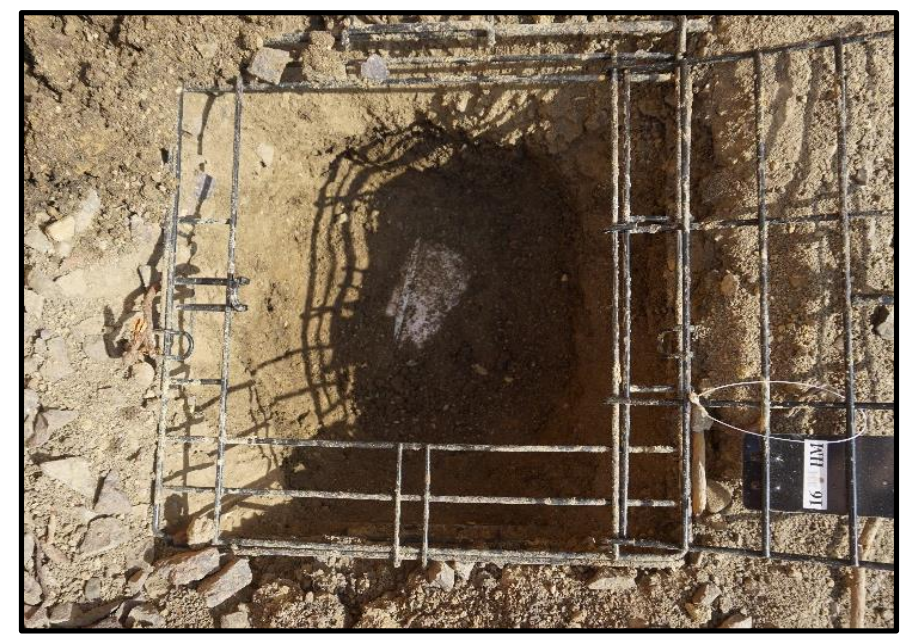

Figure 23. Top portion of specimen $\mathrm{H}$ excavated after four months. 


\section{Specimen G}

This was the last of the pig proxies to be examined. This specimen was placed 18 inches below the surface in cage 4 , and was wrapped in a white plastic garbage bag. The remaining soil within cage 5 was dug out using a small spade shovel (Figure 24). The process of identifying and analyzing specimen $\mathrm{G}$ was identical to that of specimen $\mathrm{H}$.

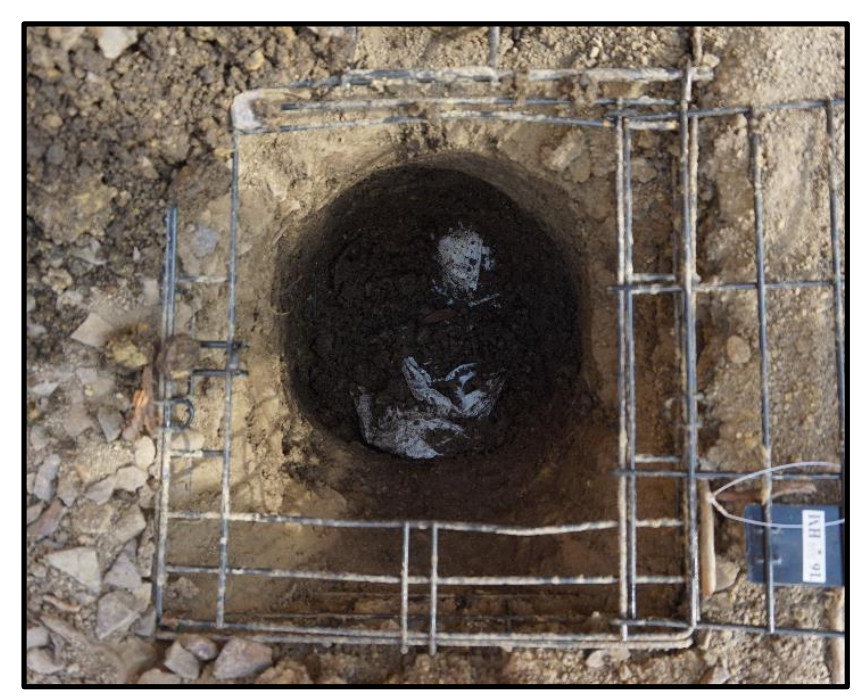

Figure 24. Top portion of specimen G excavated after four months.

Once specimen $\mathrm{G}$ and $\mathrm{H}$ had been removed from cage 4, the cage was excavated and removed from the ground. Soil was used to fill the area which had once housed the cage and the two specimens. After removal of this cage, there were no longer any cages or specimens within the ground.

At the end of the data collection, all of the remaining specimens (C, D, G, H, and I) were placed in garbage bags and disposed of in a nearby dumpster. The test site has been returned to its original condition. 


\section{CHAPTER IV: RESULTS}

Cold temperatures and weather conditions appeared to significantly impact the decomposition process of partial pig remains in central Illinois from January-May. Types of coverings on the buried specimens also impacted how a specimen decomposed over time, with those wrapped in white cotton t-shirts decomposing much more rapidly than those in plastic garbage bags. Burial depth was also influential, and it was observed that, during this time of the year, specimens buried deeper within the ground decomposed much more rapidly than those buried closer to the surface or that were placed on the ground surface. Overall, the specimens with the greatest amount of preservation over the four-month period, were those wrapped in garbage bags and buried. All ten subjects had some change in weight and circumference (Table 4) over the two- and four-month periods. Insect activity was reduced from what is normally observed in warmer conditions, with insects not becoming present until temperatures began to rise above $50^{\circ} \mathrm{F} / 10^{\circ} \mathrm{C}$.

Table 4

Each Specimens Weight and Circumference After Two- and Four-Month Examinations

\begin{tabular}{|l|c|c|c|c|c|c|c|c|c|c|}
\hline \multicolumn{8}{|c|}{ Specimens Change in Weight and Circumference } \\
\hline & \multicolumn{7}{c|}{ March 9, 2018} & \multicolumn{5}{c|}{ May 11, 2018 } \\
\hline & $\mathrm{A}$ & $\mathrm{B}$ & $\mathrm{E}$ & $\mathrm{F}$ & $\mathrm{J}$ & $\mathrm{C}$ & $\mathrm{D}$ & $\mathrm{G}$ & $\mathrm{H}$ & $\mathrm{I}$ \\
\hline Weight (lbs): & 6.5 & 5.15 & 5.9 & 5.4 & 8.0 & 5.7 & 5.11 & 4.8 & 4.1 & 4.7 \\
\hline $\begin{array}{l}\text { Circumference } \\
\text { (inches): }\end{array}$ & 27 & 27.5 & 17.5 & 16.5 & 29 & $\mathrm{~N} / \mathrm{A}$ & $\mathrm{N} / \mathrm{A}$ & 19 & 14 & 25 \\
\hline $\begin{array}{l}\text { \% Change } \\
\text { (weight/ } \\
\text { circumference): }\end{array}$ & $\begin{array}{c}9.72 / \\
-1.89 *\end{array}$ & $\begin{array}{c}20.8 / \\
0.0\end{array}$ & $\begin{array}{c}37.2 / \\
2.78\end{array}$ & $\begin{array}{c}38.3 / \\
2.94\end{array}$ & $\begin{array}{c}-2.56 * / \\
6.7\end{array}$ & $\begin{array}{c}43.0 / \\
\text { N/A }\end{array}$ & $\begin{array}{c}47.9 / \\
\text { N/A }\end{array}$ & $\begin{array}{c}44.2 / \\
-11.8\end{array}$ & $\begin{array}{c}51.2 / \\
24.3\end{array}$ & $\begin{array}{c}39.7 / \\
18\end{array}$ \\
\hline
\end{tabular}

*Negative numbers signify a percent increase in overall weight/circumference 


\section{Weather Data}

Throughout the four-month period (January-May), weather data was collected daily. This included high and low daily temperatures, humidity, wind speed, and weather observations (i.e., rain, clouds, sun, snow, sleet, ice) (Figure 24, 26, \& 27). These weather trends changed daily, and caused visible changes to occur to each of the specimens used in this study. Cold $\left(<40^{\circ} \mathrm{F} /<4.4^{\circ} \mathrm{C}\right)$, cool $\left(40-70^{\circ} \mathrm{F} / 4.4-21^{\circ} \mathrm{C}\right)$, and warm $\left(70-100^{\circ} \mathrm{F} / 20-37.8^{\circ} \mathrm{C}\right)$ were all recorded throughout the four-month period. Temperatures deemed "hot" $\left(>100^{\circ} \mathrm{F} / 37.8^{\circ} \mathrm{C}\right)$ were never observed from January to May.

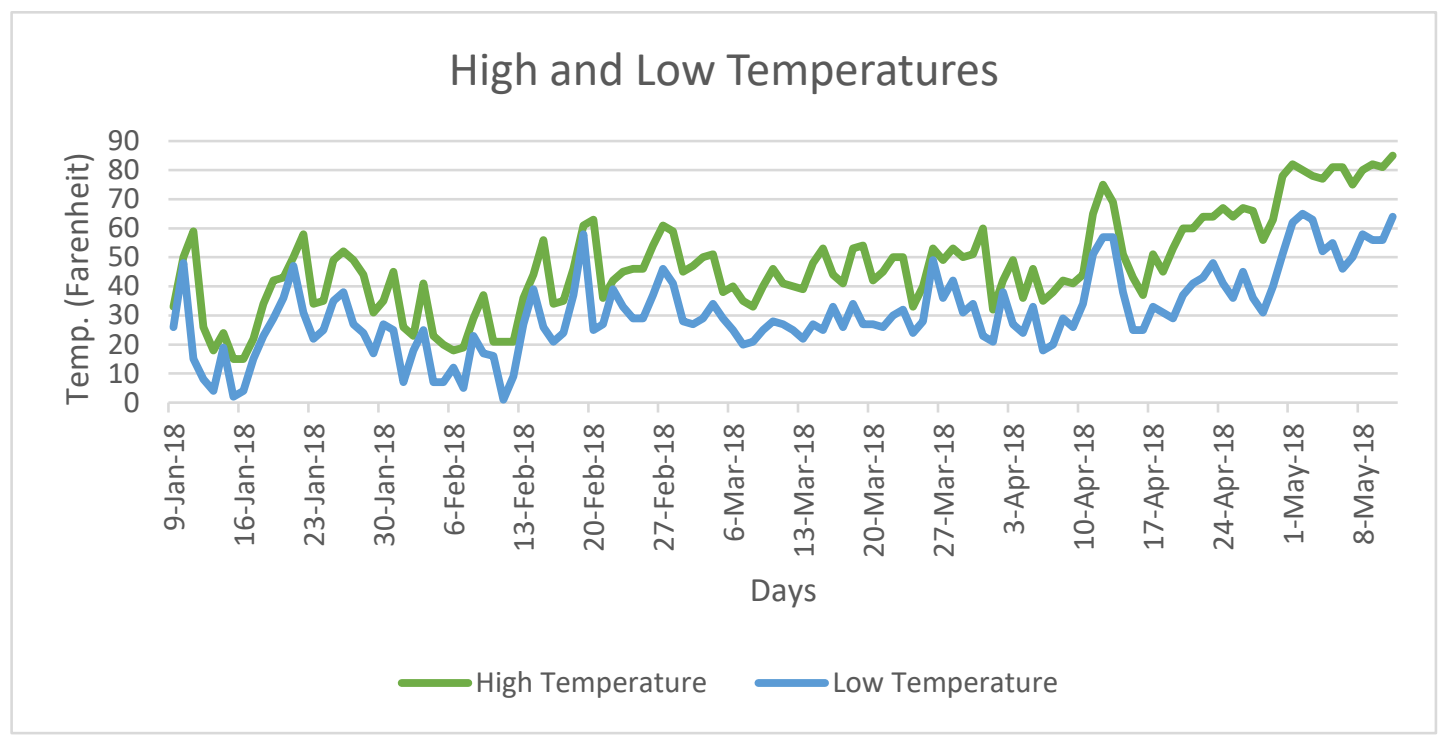

Figure 25. High and low daily temperatures from January to May 2018. 


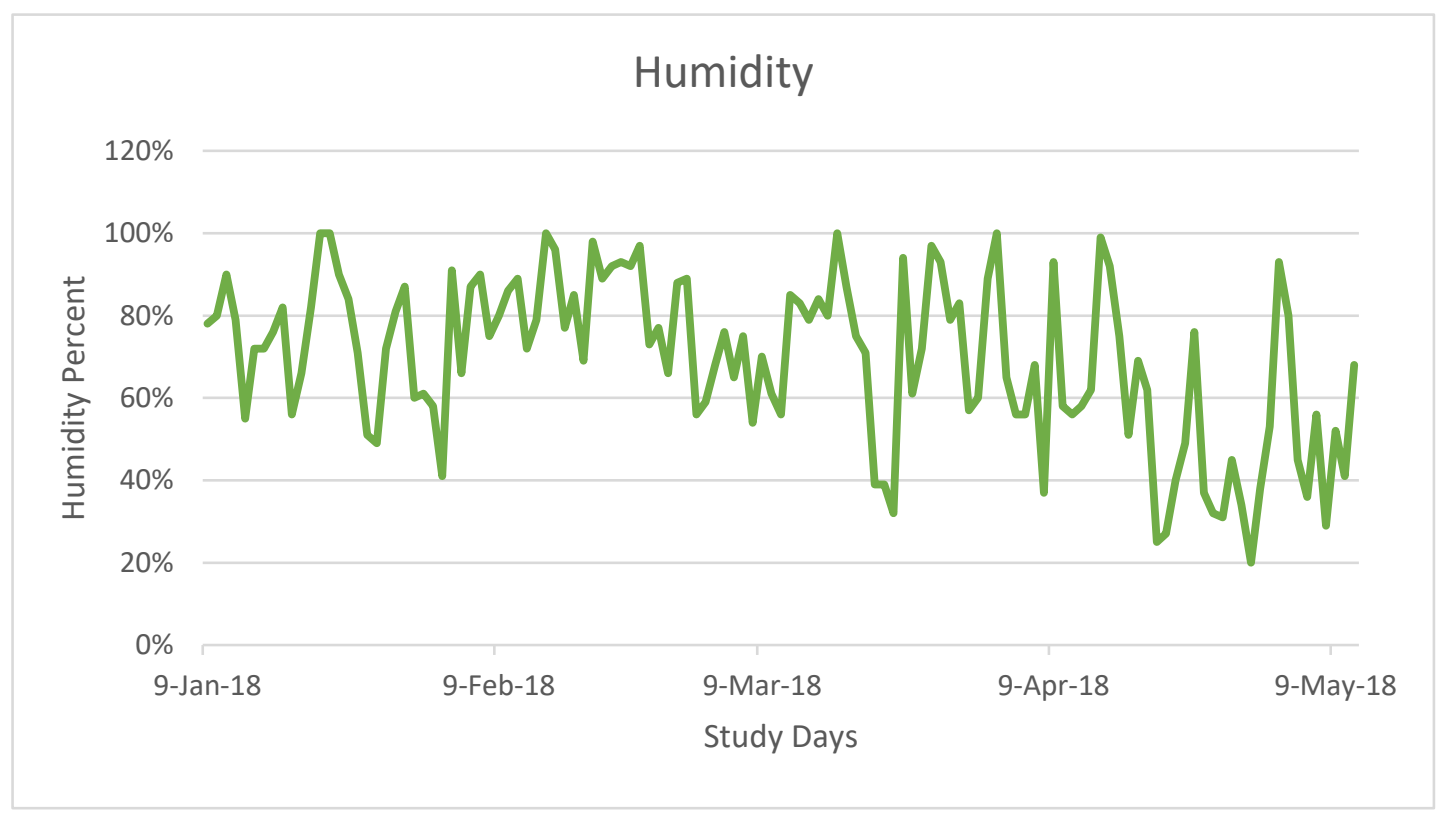

Figure 26. Daily humidity readings throughout the study period.

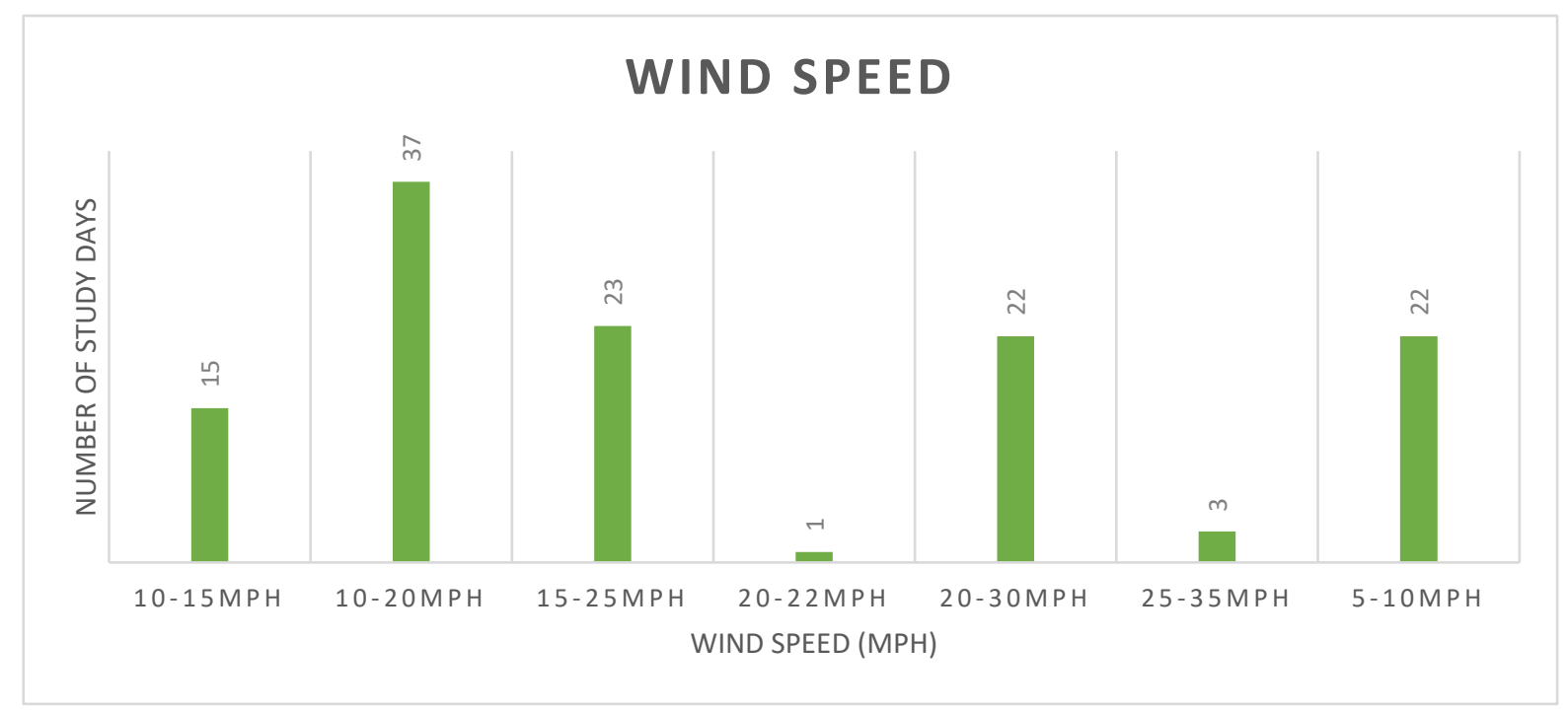

Figure 27. Wind speed readings throughout the study period. 
During the month of January (Appendix B), the lowest recorded temperature reached $2^{\circ} \mathrm{F} /-16.7^{\circ} \mathrm{C}$ on January $15^{\text {th }}$, and the high for this day was only $15^{\circ} \mathrm{F} /-9.4^{\circ} \mathrm{C}$. The highest temperature during this month reached to $59^{\circ} \mathrm{F} / 15^{\circ} \mathrm{C}$ on January $11^{\text {th }}$, and the low on this day was $15^{\circ} \mathrm{F} /-9.4^{\circ} \mathrm{C}$. The mean high from January $9^{\text {th }}$ to the $31^{\text {st }}$, was $39^{\circ} \mathrm{F} / 3.9^{\circ} \mathrm{C}$, and the mean low reached to $24^{\circ} \mathrm{F} /-4.4^{\circ} \mathrm{C}$. During the month of January, there were four periods where the temperature rose above $37^{\circ} \mathrm{F} / 2.8^{\circ} \mathrm{C}$. There were also three intervals where the temperature dropped below $37^{\circ} \mathrm{F} / 2.8^{\circ} \mathrm{C}\left(\mathrm{Jan} .13^{\text {th }}-18^{\text {th }}, 23^{\text {rd }}-24^{\text {th }}\right.$, and $\left.29^{\text {th }}-30^{\text {th }}\right)$. Daily humidity readings were also gathered in January with the highest reading at 100\% and the lowest at 49\% (Appendix B)

In February, the highest recorded daily temperature occurred on the $20^{\text {th }}$, with a temperature of $63^{\circ} \mathrm{F} / 17.2^{\circ} \mathrm{C}$, and the low for this day reached $25^{\circ} \mathrm{F} /-3.9^{\circ} \mathrm{C}$. The lowest recorded temperature occurred on February $11^{\text {th }}$, with a low of $1{ }^{\circ} \mathrm{F} /-17.2^{\circ} \mathrm{C}$ and a high for the day of $21^{\circ} \mathrm{F} /$ $-6^{\circ} \mathrm{C}$. During the day, the lowest temperature was $18^{\circ} \mathrm{F} /-7.8^{\circ} \mathrm{C}$ on February $6^{\text {th }}$. Temperature trends for the month show that there were four periods (Feb. $1^{\text {st }} 2^{\text {nd }}, 4^{\text {th }}-13^{\text {th }}, 16^{\text {th }}-17^{\text {th }}$, and the $21^{\text {st }}$ ) where the temperatures reached below $37^{\circ} \mathrm{F} / 2.8^{\circ} \mathrm{C}$, and four thaw periods where consecutive temperatures reached above $37^{\circ} \mathrm{F} / 2.8^{\circ} \mathrm{C}\left(\mathrm{Feb} .3^{\text {rd }}, 14^{\text {th }}-15^{\text {th }}, 18^{\text {th }}-20^{\text {th }}\right.$, and $\left.22^{\text {nd }}-28^{\text {th }}\right)$ (Appendix B). There were also five days where the low for the day did not drop below freezing. The average high temperature was recorded as $38^{\circ} \mathrm{F} / 3.3^{\circ} \mathrm{C}$, dropping one degree from January, and the average low was only $24^{\circ} \mathrm{F} / 4.4^{\circ} \mathrm{C}$. Humidity readings for February observed that the highest reading was $100 \%$ and the lowest at 66\% (Appendix B).

In March, the average daily temperature was $46^{\circ} \mathrm{F} / 7.8^{\circ} \mathrm{C}$, rising by approximately $8^{\circ} \mathrm{F} /-$ $13^{\circ} \mathrm{C}$ from February. The average daily low temperature was $40^{\circ} \mathrm{F} / 4.4^{\circ} \mathrm{C}$, rising by $16^{\circ} \mathrm{F} /-8.9^{\circ} \mathrm{C}$ from the previous month. The highest recorded daily temperature for the month of March was $60^{\circ} \mathrm{F} / 15.6^{\circ} \mathrm{C}$, occurring on March $31^{\text {st }}$. The low on the same day reached to $23^{\circ} \mathrm{F} /-5^{\circ} \mathrm{C}$. The 
lowest recorded temperature occurred on March $7^{\text {th }}$, with a temperature of $20^{\circ} \mathrm{F} /-6.7^{\circ} \mathrm{C}$, and the high for the day was $35^{\circ} \mathrm{F} / 1.7^{\circ} \mathrm{C}$. Overall, March experienced much longer intervals of high temperatures (above $37^{\circ} \mathrm{F} / 2.8^{\circ} \mathrm{C}$ ) (Appendix B). There were much briefer periods where the daily high temperature reached below $37^{\circ} \mathrm{F}$ (March $7^{\text {th }}-8^{\text {th }}$, and the $24^{\text {th }}$ ). However, only two days (March $26^{\text {th }}$ and $28^{\text {th }}$ ) experienced daily low temperatures that rose above $37^{\circ} \mathrm{F} / 2.8^{\circ} \mathrm{C}$. Humidity readings ranged from $54 \%$ to $100 \%$ throughout the month (Appendix B)

In April, the average daily high temperature was $53^{\circ} \mathrm{F} / 11.7^{\circ} \mathrm{C}, 7^{\circ} \mathrm{F} /-13.9^{\circ} \mathrm{C}$ higher than the mean temperature in March. The average low temperature was $35^{\circ} \mathrm{F} / 1.7^{\circ} \mathrm{C}$, which is $5^{\circ} \mathrm{F} / 15^{\circ} \mathrm{C}$ colder than the month of March. The highest daily temperature for the month of April was recorded at $78^{\circ} \mathrm{F} / 25.6^{\circ} \mathrm{C}$ and occurred on April $30^{\text {th }}$. The low on this day fell to only $51^{\circ} \mathrm{F} / 10.6^{\circ} \mathrm{C}$. The lowest recorded temperature, occurring the night of April $6^{\text {th }}$, was $18^{\circ} \mathrm{F} /-7.8^{\circ} \mathrm{C}$, and the high for the day was $35^{\circ} \mathrm{F} / 1.7^{\circ} \mathrm{C}$. The lowest recorded daily temperature, was taken on April $1^{\text {st }}$, and the temperature only reached $32^{\circ} \mathrm{F} / 0^{\circ} \mathrm{C}$. April experienced four days $\left(1^{\text {st }}, 4^{\text {th }}, 6^{\text {th }}\right.$, and $\left.16^{\text {th }}\right)$ where the high reached $37^{\circ} \mathrm{F} / 2.8^{\circ} \mathrm{C}$ or below (Appendix B). For remainder of the month, temperatures were recorded at above $37^{\circ} \mathrm{F} / 2.8^{\circ} \mathrm{C}$ (April $2^{\text {nd }}-3^{\text {rd }}, 5^{\text {th }}, 7^{\text {th }}-15^{\text {th }}$, and $17^{\text {th }}-30^{\text {th }}$ ). Twelve days in April did not experience any cold temperatures. Humidity readings ranged from $20 \%$ to $100 \%$ throughout the month (Appendix B)

During the month of May, only eleven days of temperature, humidity, wind speed, and other observations were recorded (Appendix B). Out of these eleven days, the average daily high temperature was $80^{\circ} \mathrm{F} / 26.7^{\circ} \mathrm{C}$, a full $27^{\circ} \mathrm{F} /-2.8^{\circ} \mathrm{C}$ higher than the mean temperature of April. The average daily low temperature was $57^{\circ} \mathrm{F} / 13.9^{\circ} \mathrm{C}$, which was $22^{\circ} \mathrm{F} /-5.6^{\circ} \mathrm{C}$ higher than what was experienced in April. The highest temperature recorded for this time period occurred on May $11^{\text {th }}$, when the high was $85^{\circ} \mathrm{F} / 29.4^{\circ} \mathrm{C}$. The low for this same day was $64^{\circ} \mathrm{F} / 17.8^{\circ} \mathrm{C}$. The lowest 
recorded daily temperature was $75^{\circ} \mathrm{F} / 23.9^{\circ} \mathrm{C}$, with a low of $50^{\circ} \mathrm{F} / 10^{\circ} \mathrm{C}$ on May 7 th. The lowest temperature occurred on May $6^{\text {th }}$, with a low of $46^{\circ} \mathrm{F} / 7.8^{\circ} \mathrm{C}$ during the night and a high of $81^{\circ} \mathrm{F} / 27.2^{\circ} \mathrm{C}$. No temperatures below $37^{\circ} \mathrm{F} / 2.8^{\circ} \mathrm{C}$ were recorded. In May, the humidity readings ranged from $29 \%$ to $93 \%$ (Appendix B).

\section{Two Month Examination}

\section{Specimen A: Buried 18 inches in White Cotton T-shirt}

Specimen A was wrapped in a white cotton t-shirt and placed at 18 inches below ground within cage 1 . This subject weighed 7.2 pounds and measured 26.5 inches in circumference. After two months, on March $9^{\text {th }} 2018$, specimen A was removed from the bottom of cage 1 . Upon removing this specimen from the ground, the t-shirt was still wrapped tightly around the remains. All layers of the t-shirt were moist. There was some discoloration (light brown) presumptively due to the soil (Lowe et al., 2013; Stuart \& Ueland, 2017), and the t-shirt had almost become transparent due to the amount of decomposition, making it easy to see the pink/red coloration of the muscle at the (butcher cut) exposed muscle surface (Appendix A, Figure 1a1). While removing the t-shirt, there continued to be brown discoloration of the fabric throughout the wrapped layers, but increasingly patchy areas of yellow discoloration were evident, arguably from the decomposition of fat and skin (Beever, 2014; Bostock, Parkes, \& Williams, 2018; Geisenberger et al., 2014; Lowe et al, 2013) (Appendix A, Figure 1a2). As the unwrapping proceeded and the t-shirt fabric layers got closer to the sample, it became increasingly difficult to remove the covering from the specimen. The t-shirt and specimen appeared to adhere to each other. Once specimen A was completely free from the covering, it was weighed and measured. This specimen decreased in weight by 0.7 pounds, for a total weight of 6.5 pounds. However, the circumference increased by 0.5 inches to 27 inches. 
The appearance of specimen A changed dramatically over the two-month period. The musculature, skin, and fat were all muted (i.e., less intense) in color compared to their original coloration at the start of this study (Appendix A, Figure 1b1). Although the skin texture remained intact, it took on a yellow, patchy coloration, with most of the skin maintaining an offwhite appearance. Upon handling the subject, the skin started to slip off the musculature. The external surface of the musculature was a pallid pink/brown color. However, once a circa $2 \mathrm{~mm}$ layer of muscle was scraped away, it revealed that a more intense pink color preserved internally. The bone marrow also changed in color from off-white to almost completely (i.e., more charcoal grey) black (Appendix A, Figure 1b2). Based on these observations, specimen A was scored at being between in a late stage of early decomposition (Figure 12)

Apart from the visual changes, specimen A also changed in texture. The muscle and fat were broken down (i.e., softened) to the point that it became hard to handle the subject. Break down of the tissues caused the specimen to lose structural integrity. Due to this deterioration, the bone began to protrude from the center of the specimen. No insects were present upon being unearthed, but two flies were attracted to the specimen within circa 10-20 minutes after it was taken out of the ground.

\section{Specimen B: Buried 6 inches in White Cotton T-shirt}

Specimen B was wrapped in a white cotton t-shirt and buried at the 6-inch sub-surface level within cage 1 (directly above specimen A). At recovery, it was observed that the t-shirt clung tightly to the subject on the superior side (Appendix A, Figure 2a1), with the underside becoming unraveled due to the specimen shrinking over time. The entirety of the t-shirt was moist. The t-shirt was discolored from the dirt and took on a light brown appearance all over the outer surface. The t-shirt also became somewhat transparent on the superior surface enabling 
visibility of the brown/pink coloration of the muscle. As the t-shirt was unwrapped, there were patches of yellow stain where the cotton had come in contact with the specimen (Appendix A, Figure 2a2). At the beginning of this study, specimen B weighed 6.6 pounds and measured 27.5 inches in circumference. When specimen B was completely unwrapped, it was weighed and measured. It had decreased in weight by 1.45 pounds to a total of 5.15 pounds. There was no change in circumference and stayed at 27.5 inches.

Visual examination showed that the coloration of specimen B had changed. The skin and fat took on a comparatively whiter appearance, with the skin exhibiting patchy areas of yellow staining (Appendix A, Figure 2b1). The musculature took on a muted pink/brown color. Upon scraping a small patch of the surface of circa $1 \mathrm{~mm}$ of muscle, the musculature was a much brighter pink. When the surface musculature was touched or handled, the contact created a darkened coloration (Appendix A, Figure 2b2). The superior surface (i.e., the up side) of the bone marrow also changed in color, with the majority remaining white, while some areas had turned charcoal-black. The inferior portion (i.e., underside) of the bone changed to a more yellowed coloration with patches of red spread across the surface (Appendix A, Figure 2c1).

It was difficult to handle the specimen once it had been unwrapped, and the integrity of the musculature changed to the point that any touch altered the external surface. This alteration included the musculature maintaining an imprint in the location that it was touched. The bone was also protruding from the center of the specimen, and, when handled, became loose (i.e., could be easily moved). Due to these observations, specimen B was considered to be in the early stages of decomposition (Figure 12). Immediately after being unearthed, one fly was attracted to the remains, and upon completion of examination (circa 20 minutes), three flies had arrived. 


\section{Specimen E: Buried 18 inches in Plastic Garbage Bag}

Specimen E was wrapped in a plastic garbage bag and buried 18 inches below the surface within cage 3. At the time of burial, this specimen weighed 9.4 pounds and measured 18 inches in circumference. Upon removal of the surrounding soil and extraction from the ground, the white garbage bag was unraveled from around the specimen and as the layers of wrap became closer to the surface, it became easy to see the pink muscle color of subject E (Appendix A, Figure 3a1). It was also apparent that decompositional fluids had built up inside the garbage bag over the course of two months. Once subject $\mathrm{E}$ was removed from the garbage bag, it was weighed and measured. At the time of burial, this specimen weighed 9.4 pounds and measured 18 inches in circumference. It had decreased in weight by 3.5 pounds to a total of 5.9 pounds, and also decreased in circumference to 17.5 inches.

Specimen E remained essentially intact through the two-month period that it was buried. The skin was tough, easily pliable, and white in color, although there were pink decompositional, fluids (i.e., sealed plastic bag environment) covering the entirety of the outer surface (Appendix A, Figure 3a2). The muscle was still fairly pink (i.e., duller than at time of burial) in appearance with patches that had turned a more muted brown color (Appendix A, Figure 3b1). When the skin was peeled back, it revealed that the musculature was bright pink where the skin had shielded it. The exposed (cut) surface of the bone had become a bright red color (Appendix A, Figure 3b2), and this coloration seeped into the internal marrow.

Specimen E was easy to handle, as advanced stages of decomposition had not altered the composition of the musculature or skin to the point of total breakdown. This subject was believed to be in a late stage of early decomposition (Figure 12). The musculature was remained relatively firm to the touch, but had slightly receded from the top portion of the bone. While the 
examination was occurring, there were no insects present and no insects were found inside the garbage bag on specimen E.

\section{Specimen F: Buried 6 inches in Plastic Garbage Bag}

Specimen $\mathrm{F}$ was buried at 6 inches within cage 3 and wrapped in a plastic garbage bag. This specimen initially weighed 9 pounds and measured 17 inches in circumference prior to being buried in the ground. When the specimen was removed from cage 3 , it was observed that the garbage bag clung tightly to the subject and was covered in a light layer of soil (Appendix A, Figure 4a1). As the bag was unwrapped, the coloration of the subject became visible through the surface of the garbage bag. It appeared light pink in color, with patches that were more saturated (i.e., bright pink). It was also evident that decompositional fluids had accumulated within the garbage bag. The garbage bag was easily removed from specimen $\mathrm{F}$, and at this point, the subject was weighed and measured. Specimen F decreased in weight by 3.6 pounds to a total weight of 5.4 pounds. This subject also decreased in overall circumference to 16.5 inches.

Further examination of specimen F observed that the external surface of the skin was covered in a light pink decompositional fluid. When this was wiped away, it revealed that the skin had remained relatively white in color with a few areas that had turned yellow (Appendix A, Figure 4a2). The musculature's external surface had turned to a pinkish-brown color, and when the internal structure of the musculature was examined (surface scraping of circa $1 \mathrm{~cm}$ ), it was revealed that it had remained more saturated in color (Appendix A, Figure 4b1). The outer surface of the cut end of the bone was bright red in color (Appendix A, Figure 4b2), and this coloration seeped into the marrow of the bone so that it contrasted in appearance compared to the musculature surrounding it. 
Handling specimen F was relatively easy, the skin and musculature remained firm and did not fall apart when it was picked up or examined. Specimen F was considered to be between the fresh and early stages of decomposition (Figure 12). No insects were present when the garbage bag was unwrapped or throughout the duration of examination.

\section{Specimen J: Surface}

Specimen J was photographed and documented daily throughout the two-month period. Before placement, the subject was weighed and the circumference measured. The initial weight of the specimen was 7.8 pounds and it measured 31 inches in circumference.

\section{January.}

In January, twelve days can be categorized as cold environments (i.e., daytime high temperature was $<37^{\circ} \mathrm{F} / 2.8^{\circ} \mathrm{C}$. On January $9^{\text {th }}$, the specimen was placed on the ground surface and on January $11^{\text {th }}$, the first changes were documented. That day experienced periods of rain; the temperature high was $59^{\circ} \mathrm{F} / 15^{\circ} \mathrm{C}$. The subject appeared much more muted in color (Appendix A, Figure 5a1). There was no change in the physical integrity of the skin, muscle or fat.

The following day, January $12^{\text {th }}$, experienced a decrease in temperature $\left(26^{\circ} \mathrm{F} /-3.3^{\circ} \mathrm{C}\right)$ with a low of $8^{\circ} \mathrm{F} /-13.3^{\circ} \mathrm{C}$ ). When the subject was observed, it was evident that the external surface had experienced freezer burn (i.e., dehydration and oxidation) to the exposed musculature, evidenced by the hardened "rough" appearance on the superior surface (Appendix A, Figure 5a2). This type of change also caused the subject's musculature to turn browner in color. These changes progressively continued until January $15^{\text {th }}$ when it snowed approximately 3 inches, and visual observations were not possible. The temperature from January 12 to January 17 remained below freezing. 
It was not until January $20^{\text {th }}$ that specimen $\mathrm{J}$ was completely visible (i.e., snow melt), and it was obvious that there was bleaching (i.e., the specimen was much lighter in color). There was also freezer burn on much of the superior surface. The bone marrow of specimen $\mathrm{J}$ also began to change color from white to a more grey/black color. On this same day, there were periods of rain $\left(43^{\circ} \mathrm{F} / 6.7^{\circ} \mathrm{C}\right)$ that saturated the specimen (Appendix A, Figure $\left.5 \mathrm{~b} 1\right)$. On January $24^{\text {th }}$, specimen $\mathrm{J}$ exhibited more freezer burn (more surface area and comparatively more roughened texture) and more desiccation (Appendix A, Figure 5b2). This change included the musculature to become darkened in color. By January $26^{\text {th }}$, specimen $\mathrm{J}$ was relatively much darker in color. The skin also appears to have shrunk, revealing more of the musculature that had previously been protected. At this time, specimen $\mathrm{J}$ almost looks like plastic and has a waxy sheen.

Specimen $\mathrm{J}$ continued to darken in color through the end of the month (January $31^{\text {st }}$ ) and the areas on the surface that experienced freezer burn continued to roughen (Appendix A, Figure 5c1). At this time, blood began to seep out from the center of the bone marrow.

\section{February.}

February had fifteen days of a cold environmental temperatures and conditions, particularly after the middle of the month. Three days were above $60^{\circ} \mathrm{F} / 15.5^{\circ} \mathrm{C}$. From February $1^{\text {st }}$ through February $3^{\text {rd }}$, the subject continued to darken in color and have a hardened external appearance (Appendix A, Figure 6a1). By February $3^{\text {rd }}$, it looked as though the subject had shrunk in overall circumference. On February $4^{\text {th }}$, less than one inch of snow had accumulated throughout the night, and this snow continued throughout the day ( 1-inch accumulation). Light snow covered a portion of specimen $\mathrm{J}$ (Appendix A, Figure 6a2), and by February $5^{\text {th }}$ the specimen was completely covered by snow (Appendix, Figure 30b1). An additional 3-5 inches of 
snow fell on February $6^{\text {th }}$, adding to the amount of snow covering specimen J (Appendix A, Figure $6 \mathrm{~b} 2)$. The temperature from February $4^{\text {th }}$ to February $13^{\text {th }}$ remained below freezing.

It was not until February $14^{\text {th }}$ that the subject became completely visible. At this time, the temperature rose to $44^{\circ} \mathrm{F}\left(6.7^{\circ} \mathrm{C}\right)$ and it was observed that the subject was more bleached in color with some areas turning grey with some portions of purple/blue (Appendix A, Figure 6c1). Compared to the beginning of the snowfall, the subject was wet. There was some blood that was also leeching from the bone marrow. Specimen $\mathrm{J}$ continued to have the same wet, bleached, and discolored appearance through February $15^{\text {th }}$ (Appendix A, Figure 6c2). This day also experienced a rise in temperature by $12^{\circ} \mathrm{F}\left(-11.1^{\circ} \mathrm{C}\right)$ to $56^{\circ} \mathrm{F}\left(13.3^{\circ} \mathrm{C}\right)$ for the high. By February $16^{\text {th }}$, specimen $\mathrm{J}$ had become redder/pinker in color throughout the entirety of its musculature (Appendix A, Figure 6d1). The changes associated with freezer burn along the superior surface were retained. Less than one inch of snow fell on February $17^{\text {th }}$, covering the majority of specimen J (Appendix A, Figure 6d2), but it had completely melted by the $18^{\text {th }}$. Observations on February $18^{\text {th }}$ showed that the subject appeared darker in color throughout the musculature, with areas of freezer burn continuing to be present (Appendix A, Figure 6e1). There was no noticeable change to specimen $\mathrm{J}$ on the $19^{\text {th }}$, but the rain that had fallen in the morning had caused some soil to be splattered across the surface of the subject.

The temperature also rose to $61^{\circ} \mathrm{F}\left(16^{\circ} \mathrm{C}\right)$ on the $19^{\text {th }}$ and $63^{\circ} \mathrm{F}\left(17.2^{\circ} \mathrm{C}\right)$ on the $20^{\text {th }}$. This rise in temperature caused the specimen to emit a foul odor that could be detected by a human from a distance of twenty feet. On February $21^{\text {st }}$, the temperature had fallen to $36^{\circ} \mathrm{F}\left(2.2^{\circ} \mathrm{C}\right)$, and freezing rain caused ice to form around the cage protecting the surface specimens. Specimen J continued to be bleached in appearance and the inferior portion of the skin seemed to become detached from the musculature (Appendix A, Figure 6e2). 
On February $23^{\text {rd }}\left(45^{\circ} \mathrm{F} / 7.2^{\circ} \mathrm{C}\right)$, there was a noticeable change in the coloration. The musculature appeared much pinker/redder in color, and the areas of freezer burn were not as noticeable as previous days. The marrow from specimen $\mathrm{J}$ was emitting red fluids that began to flow down into the musculature (Appendix A, Figure $6 \mathrm{f1}$ ). By the $24^{\text {th }}$, fluid was no longer flowing from the bone marrow, but the rain throughout the day caused the specimen to become wet and bleached in coloration (Appendix A, Figure 6f2). Rain continued throughout the night into the morning of the $25^{\text {th }}$, but it had become sunny throughout the day $\left(46^{\circ} \mathrm{F} / 7.8^{\circ} \mathrm{C}\right)$ on February $25^{\text {th }}$. This caused the specimen to become redder in color and some fluids began to be emitted from the perimeter of the bone marrow (Appendix A, Figure 6g1). The location of this draining fluid changed throughout the study period. There was also a strong odor that could be smelled coming from the specimen when temperatures increased above $37^{\circ} \mathrm{F} / 2.8^{\circ} \mathrm{C}$. Sun throughout the day continued into the $27^{\text {th }}$. Observations on these days $\left(46-61^{\circ} \mathrm{F} / 7.8-16^{\circ} \mathrm{C}\right)$ showed that specimen $\mathrm{J}$ became darker red in color, and took on a dried-out appearance with the musculature looking tough and stringy (Appendix A, Figure 6g2). Red fluid also continued to leach from the bone marrow, and the marrow also began to darken in color (Appendix A, Figure 6h1). Light rain fell during the night of the $27^{\text {th }}$ into the morning of the $28^{\text {th }}$. During this time, specimen J appeared largely the same, but had become wet due to the rainfall. It also appeared as though the musculature was receding from the bone, causing the bone to protrude from the specimen (Appendix A, Figure 6h2).

\section{March.}

March had twenty-eight days above freezing and twelve days above $50^{\circ} \mathrm{F} / 10^{\circ} \mathrm{C}$ with six days of rainfall. Rain fell throughout the day on March $1^{\text {st }}$, and the musculature change in color to a much darker brown, and the fat and skin were white in contrast (Appendix A, Figure 7a1). 
By March $2^{\text {nd }}$ the sun had emerged and specimen $\mathrm{J}$ had changed in color from dark brown to redder and dried-out in appearance. The fat running through the musculature also began to change color from white to a more saturated yellow (Appendix A, Figure 7a2). No change was visible until March $4^{\text {th }}$, when the musculature of the specimen became much darker and almost black in coloration. The external surface appeared hardened and "aged", with it being visibly dried out (Appendix A, Figure 7b1). The fat running through the musculature also began to recede, and was hardly visible. On March $5^{\text {th }}$, rain fell continuously throughout the day, causing specimen $\mathrm{J}$ to become wet. The subject continued to appear dark in color, but the fat and skin were whiter in color (Appendix A, Figure 7b2). There were also areas of red fluid seeping from the marrow and fat running through the specimen. The rain had ceased by March $6^{\text {th }}$, and the only change to the specimen was that it was no longer wet and had become dried out again. By the $7^{\text {th }}$, light snow had developed ( $<1$-inch) and the subject was lightly covered (Appendix A, Figure $7 \mathrm{c} 1)$. On this day, the musculature of the specimen was dark in color with patches that were brown and looked like freezer burn. The fat had also turned more yellow in color, and the bone marrow continued to be dark in color with almost the entire perimeter of the bone marrow being darker in color. By March $8^{\text {th }}$, subject $\mathrm{J}$ appeared dark and leathery. There were also streaks of fat running throughout the entirety of the musculature, which appeared white in color and contrasted with the dark musculature (Appendix A, Figure 7c2).

On March $9^{\text {th }} 2018$, Specimen J was removed from cage 5 on the ground surface. Upon removal of the cage, it was observed that the specimen was dark brown/black in color throughout the musculature on the superior surface. There was streaks of fat running throughout the musculature that maintained their white color throughout the two-month period (Appendix A, Figure 8a1). On the superior most portion of specimen $\mathbf{J}$ there was a small area of musculature 
that remained red in color and white/yellow fat surrounded this area. A line of fat running through the entirety of the musculature on the superior surface had multiple colors running through (i.e., red, yellow, dark brown, white) (Appendix A, Figure 8a2). The entire surface of the musculature was hard to the touch and it had a leathery, aged appearance. The marrow was dark in color (grey/brown) and there was a fine line running around the inner circumference of the bone that had taken on a reddened coloration.

Next, specimen $\mathrm{J}$ was removed from the ground surface to be weighed and measured. It was difficult to remove the specimen due to it being completely frozen, as well as frozen to the ground, and there was soil that remained attached to the inferior portion of the specimen. After two months, the specimen gained 0.2 pounds and weighed 8 pounds. However, specimen $\mathrm{J}$ lost 2 inches in circumference to measure 29 inches. The skin of the specimen had turned yellow in color with areas that appeared pink/red (Appendix A, Figure 8b1). The surface of the specimen (inferior) that had remained on the ground surface was slightly wet and had a light odor coming from it. The fat in this area was soft to the touch and there was a yellow fluid that had pooled in one area (Appendix A, Figure 8b2). The musculature in this area was also soft to the touch and was a much lighter pink color. It was relatively easy to handle specimen $\mathrm{J}$, and it stayed intact throughout the entire examination. After two months, specimen $\mathbf{J}$ was placed in the early stages of advanced decomposition, since the majority of the outer surface had desiccated (i.e., mummified) (Figure 12).

\section{Four Month Examination}

\section{Specimen C: Buried 18 inches in White Cotton T-shirt}

From May1st-11 ${ }^{\text {th }}$, zero days of cold temperature were recorded, with the high daily temperatures ranging from $75-85^{\circ} \mathrm{F} / 23.9-29.4^{\circ} \mathrm{C}$. On May $11^{\text {th }} 2018$, specimen $\mathrm{C}$ was recovered 
from the 18 -inch depth within cage 2 . The subject initially weighed 10 pounds and measured 27 inches in circumference. As specimen $\mathrm{C}$ was being removed from within the cage, there was a strong odor emitted and it was difficult to remove the subject intact due to the amount of decomposition. Upon removal from the cage, the t-shirt was wet and stained brown/yellow. Liquefaction from the amount of decomposition also left some clear fluid on the soil surface in cage 2. There were also grey/black areas that on the t-shirt (Appendix A, Figure 9a1). Soil clung to the t-shirt and was difficult to remove due to the amount of moisture. Closer inspection of the covering showed that there were maggots covering the surface (Appendix A, Figure 9a2). It is unknown what species these maggots belonged to or how many were actually present across the t-shirts surface, but they did measure around $1 / 4$ inch in length. As the $t$-shirt was being removed from specimen $\mathrm{C}$, the shirt took on a more yellowed coloration with areas of pink, and the number of maggots began to reduce in numbers between the layers. A large hole had formed in the covering along the right side, and the specimen could be seen through this hole (Appendix A, Figure 9b1).

When the t-shirt was opened to expose specimen C, it revealed that the subject had almost completely liquefied. There were areas of fat that had remained white, and the musculature maintained a pink coloration, although it was more diluted. The skin had almost completely liquefied, but there were several small areas where it had remained intact (Appendix A, Figure 9b2). The inner bone was no longer attached to the musculature and could be easily removed from the specimen (Appendix A, Figure 9c1). Due to these changes, specimen C was categorized as being in a very advanced stage of decomposition (Figure 12). In order to weigh the specimen, the t-shirt had to stay wrapped around the specimen. The specimen lost 4.7 pounds to weigh 5.7 pounds with the t-shirt. The circumference could not be taken due to the advanced 
decomposition and liquefaction that had taken place throughout the four-month period. Specimen $\mathrm{C}$ was difficult to handle and move due to the consistency of the subject. The entirety of the specimen took on a viscous-like consistency, including the fat, skin, and musculature (Appendix A, Figure 9c2). This specimen also had a very strong, pungent odor that could be smelled from the moment it was unearthed in the cage until the examination was completed. It almost immediately attracted flies and throughout the examination, there were a number of flies present on and around the specimen.

\section{Specimen D: Buried 6 inches in White Cotton T-shirt}

Specimen D was removed from the 6-inch depth within cage 2 on May $11^{\text {th }} 2018$. This subject initially weighed 9.8 pounds and measured 26.5 inches in circumference. As the specimen was being removed from within the cage, it was difficult to handle due to the advance decomposition and there was a strong odor being emitted. When specimen D was completely removed, it had left a small area of fluid on the soil surface. The outer surface of the t-shirt was covered in soil and there was a patch of what looked like adipocere (Appendix A, Figure 10a1) formation on the inferior portion of the t-shirt. The t-shirt was also stained yellow with some areas maintaining its original white coloration. The shirt was also wet and parts were transparent, so the specimen could be seen through the covering. On the outer surface of the t-shirt, there were only a handful of maggots. It is uncertain how many maggots were actually present on this specimen or what species they belonged to, although they did measure to approximately $1 / 4$ inches. As the t-shirt was unwrapped the yellow coloring continued throughout the layers, with some areas that remained white (Appendix A, Figure 10b1). The covering was also beginning to break down, with small areas on the collar and right armband experiencing this change (Appendix A, Figure 10b2). There was also a larger area of disintegration along both sides of the 
t-shirt. It was difficult to remove the shirt from the specimen, and it had to remain in the t-shirt in order to conduct the examination.

The skin of specimen D remained relatively intact (Appendix A, Figure 10c1), but there were areas of the skin that had turned black in color. The fat had begun to liquify, but maintained a white coloration, with the areas of fat within the musculature being more yellowed. The musculature was also beginning to liquify and had remained pink in overall color, although it did appear duller (Appendix A, Figure 10c2). The bone of specimen D was loosened from the musculature, and could be easily moved but not completely removed from the specimen. Based on the observations made during the four-month examination, specimen D was categorized as being in an advanced stage of decomposition (Figure 12). Due to the amount of decomposition, specimen D had to be weighed while still wrapped in the t-shirt, and it had decreased in weight by 4.69 pounds to 5.11 pounds. The specimen could not be measured for circumference because the specimen had become too liquefied and difficult to handle. As soon as the specimen was extracted from the ground, there were flies present on and around the specimen.

\section{Specimen G: Buried 18 inches in Plastic Garbage Bag}

Specimen $G$ was removed from the 18 -inch depth within cage 4 on May $11^{\text {th }} 2018$. The initial examination recorded that this subject weighed 8.6 pounds and measured 17 inches in circumference. While removing the subject from cage 4, there was no strong odor being emitted from within. When specimen $\mathrm{G}$ was completely removed from within the ground, it was observed that the garbage bag clung tightly to the specimen and there was soil that was stuck to the outer surface of the bag. As the garbage bag became unraveled, the pink coloration of the specimen could be seen through the bag (Appendix A, Figure 11a1). When the bag was opened, a strong, pungent odor could be smelled. Upon removal, specimen G was covered in a diluted 
pink fluid that covered the entire surface of the specimen (Appendix A, Figure 11a2). A substantial amount of this fluid was also present within the garbage bag. Visual examinations observed that the skin was white in color with some areas that had turned light yellow (Appendix A, Figure 11b1). The musculature was a muted pink color with areas that appeared browner in color (Appendix A, Figure 11b2). There were some areas of fat that remained white, although it appeared as if the majority of it decomposed completely. The bone projected slightly from the specimen, was light brown in color, and had the pink fluid covering it as well. Due to these decompositional changes, specimen $\mathrm{G}$ was categorized as being in an advanced stage of decomposition (Figure 12).

After visual observations, the specimen was weighed and measured. Specimen G lost 3.8 pounds and weighed 4.8 pounds during examination and gained 2 inches to measure 19 inches in circumference. When handling the specimen, the skin was still relatively tough, but portions of the skin began to disintegrate upon too much handling (Appendix A, Figure 11c1). The musculature was soft and relatively viscous. The musculature could not be handled too much, otherwise it began to fall apart. When specimen $\mathrm{G}$ was released from the garbage bag, flies immediately became attracted to the specimen and were present throughout the examination.

\section{Specimen H: Buried 6 inches in Plastic Garbage Bag}

Specimen $H$ was unearthed from the 6-inch depth within cage 4 on May $11^{\text {th }} 2018$. The initial weight of the specimen was 8.5 pounds and measured 18.5 inches in circumference. Upon removal of the specimen from the cage, no odor was emitted from the subject. Once specimen $\mathrm{H}$ was removed from within the ground, it was observed that the garbage bag clung tightly to the specimen, and there were areas of soil that covered the outer surface of the bag. As the garbage bag was being unwrapped, there was a light pink fluid within the garbage bag that was visible 
through the bags surface (Appendix A, Figure 12a1). This transparency allowed for the darkened musculature and light skin and fat to be observed through the garbage bag. When the bag was opened, and specimen $\mathrm{H}$ retrieved, visual observations were made. The skin was still tough to the touch and could be handled easily. The skin had maintained its white color with the pink fluid covering the entire surface, and there were some areas of the skin that had turned pink (Appendix A, Figure 12a2). The musculature was a more yellowed/brown color with streaks of fat running through the surface of the muscle (Appendix A, Figure 12b1). When the skin was peeled away to reveal the subcutaneous musculature, it was revealed that this area had maintained a bright pink (i.e., fresh) coloration. The bone slightly protruded from the musculature, and the majority remained white, although there were some areas that had turned brighter red (Appendix A, Figure 12b2). From the observations made during the four-month examination, this subject was believed to be in the early stages of advanced decomposition (Figure 12).

After visual observations were conducted, specimen $\mathrm{H}$ was weighed and measured. Specimen $\mathrm{H}$ had lost 4.4 pounds to weigh a total of 4.10 pounds and measured 14 inches in circumference. The specimen was still relatively fresh in appearance and displayed no signs of advanced decomposition. The musculature was soft to the touch, but did not fall apart and had maintained its shape. The decompositional fluids that remained within the garbage bag were minimal. Flies instantly became attracted once the specimen was out of the garbage bag, and were present throughout the entirety of the examination.

\section{Specimen I: Surface}

Specimen I was photographed and observed daily from January $9^{\text {th }}$ to May $11^{\text {th }}$. Before placement on the ground surface beneath cage 5, the subject was weighed and measured. The initial weight of specimen I was 7.8 pounds and measured 30.5 inches in circumference. 


\section{January.}

Two days after initial placement, on January $11^{\text {th }}$, the first signs of change were visible. At this time, specimen I appeared lighter in overall color, especially throughout its musculature. By January $12^{\text {th }}$, the majority of the superior surface had experienced freezer burn, causing the musculature to become browner in color and the surface to become rough, and hardened in appearance (Appendix A, Figure 13a1). There was little change until January $14^{\text {th }}$, when the area experiencing freezer burn had expanded across the majority of the superior surface. Few areas remained red/pink in color, maintaining a fresh appearance. From January $15^{\text {th }}-19^{\text {th }}$, specimen I was covered by a sheet of snow, and no complete visual observations could be made.

On January $20^{\text {th }}$, the snow had completely melted, and the specimen appeared much lighter in overall color. The proximal portion of specimen I was almost white and maintained areas of freezer burn throughout the musculature. One area of the musculature, along the distal end, remained red/pink in color (Appendix A, Figure 13a2). By January $21^{\text {nd }}$, the bone marrow was beginning to turn color from white to a more yellowed/brown color. A dark spot also developed along the proximal end of the musculature (Appendix A, Figure 13b1). Little change occurred until January $26^{\text {th }}\left(52^{\circ} \mathrm{F} / 11^{\circ} \mathrm{C}\right)$ when the color of specimen I had darkened in color with some areas remaining lighter (Appendix A, Figure 13b2). The skin also appears to have shrunk slightly along the perimeter of the musculature. The entirety of specimen I remained dried-out and desiccated in appearance.

By January $30^{\text {th }}$, the subject had darkened in color throughout the musculature to a much darker red/pink. This coloration was especially present along the distal end of the musculature. The proximal end remained lighter pink in color and had areas of darkened freezer burn (Appendix A, Figure 13c1). The fat of specimen I looked tough and almost waxy in consistency 
compared to other aspects of the subject. The perimeter, along the proximal end of specimen I contained the most amount of freezer burn, which was a light brown/yellow in appearance. After one day, on January $31^{\text {st }}$, the musculature had darkened even further in color to a dark red with some areas that appeared blackened (Appendix A, Figure 13c2). The marrow also began to change color in one area being greyer in color, and the perimeter of the marrow along the bone began to darken.

\section{February.}

On February $1^{\text {st }}$, the appearance of the specimen changed relatively little. The only noticeable change was that the skin appeared to become more yellow in color compared to its original off-white. Few visual changes could be observed until February $4^{\text {th }}$ when there was a light dusting ( $<1$ inch) of snow that fell, covering the superior surface (Appendix A, Figure 14a1). The snow continued to fall until February $5^{\text {th }}$, when specimen I could no longer be visually observed (Appendix A, Figure 14a2). It was not until February $14^{\text {th }}$ that the snow had melted enough for the specimen to be observed more fully. After the snow melted, the subject appeared more bleached (i.e., subdued) in color, with some areas appearing almost purple/blue along the distal end (Appendix A, Figure 14b1). The proximal portion of the musculaturemaintained areas of light brown/yellow coloration that was previously associated with freezer burn. The marrow also lightened in color and the areas of discoloration were no longer visible.

There was no longer any snow on the ground on February $15^{\text {th }}$. On this day, specimen I continued to appear bleached in color. The skin was white, and the musculature contained a variety of colors, including red/pink, brown, blue, purple, yellow. The specimen also appeared to be wet throughout the entire surface. By the next day, February $16^{\text {th }}$, the musculature had darkened in color along the distal end of the specimen. The marrow also began to change color in 
one area to a more grey/yellow coloration (Appendix A, Figure 14b2). Around one inch of snow fell on February $17^{\text {th }}$, covering the majority of the superior surface of specimen I (Appendix A, Figure 14c1). By February $18^{\text {th }}$, the snow around the specimen had completely melted. The specimen continued to appeared red/pink in color throughout the musculature, with areas of freezer burn especially present along the proximal end.

Due to the rain on February $19^{\text {th }}$, the specimen appeared much greyer in color and washed-out. The skin and fat were white against the musculature and the marrow changed colors again to be completely white (Appendix A, Figure 14c2). The rain also splashed some soil onto the superior surface of the specimen. This was the first day that an odor was present when the specimen was observed and could be smelled upon approach to cage 5. Little change occurred until February $21^{\text {st }}$, when the color of specimen I became a browner, muted muscle tissue. The majority of the superior surface was also covered by a splattering of soil, which was now more visible due to the lighter color of the subject. The fat running through the musculature also began to split apart, causing holes to form through the fat and musculature in this area (Appendix A, Figure $14 \mathrm{~d} 1$ ). By February $23^{\text {rd }}$, the specimen became redder/pinker in coloration throughout the musculature. The marrow and skin maintained their white coloration.

Rain fell on February $24^{\text {th }}$, saturating the specimen, and causing the musculature, skin, fat, and marrow to become bleached in color. On February $25^{\text {th }}$, the rain had ceased and specimen I appeared darker in color throughout the musculature. The skin also began to change color from white to a more yellowed coloration. It also appeared as though the opening running the length of the specimen had widened, causing even more holes to form and the fat to be visible (Appendix A, Figure 14d2). The outer rim of the marrow, along the bone, also became pinker. The specimen continued to change in appearance into February $26^{\text {th }}$. On this day, the 
musculature appeared much more desiccated and darker in coloration. The proximal end of the specimen was dark brown to almost black. The distal portion of the musculature remained dark red (Appendix A, Figure 14e1). The skin also continued to yellow in coloration, and the marrow began to darken. The fat running through the musculature began to turn yellow in color and there were areas that had turned almost black due to holes forming in these areas. Little change occurred until February $28^{\text {th }}$, when the specimen deepened in color. The coloration turned to an even darker red to almost black. The marrow also began emitting a red fluid, which flowed onto the musculature (Appendix A, Figure 14e2).

\section{March.}

On March $1^{\text {st }}$, rain had fallen throughout the day, causing the specimen to bleach in color. The musculature turned to a lighter brown, and the areas of fat running through stood out due to their white coloration. The opening through the length of the musculature also appeared to have widened with more holes appearing to have formed in this area (Appendix A, Figure 15a1). There was also a small area on the marrow from where a light-yellow fluid was seeping. On March $2^{\text {nd }}$, the musculature had deepened in color to a darker red. This area of the specimen seemed dried out and aged in appearance. The skin also changed in color to yellow. This yellow coloration also appeared in the fat running through the opening in the musculature (Appendix A, Figure 15a2). Fluid was no longer seeping from the marrow, although, it did appear greyer with areas of yellow. The deepening of overall color continued into March $3^{\text {rd }}$. On this day, the fat running throughout the entirety of the musculature appeared light in contrast with the dark red/brown (Appendix A, Figure 15b1). The large opening also saw a change in coloration. The musculature in this area was much redder than the surrounding musculature. The fat also continued to become yellow in coloration. No visible changes were observed until March $5^{\text {th }}$, at 
which time the specimen was saturated from the rain. The musculature continued darken in color, and the fat and skin had turned to an off-white coloration. The marrow of specimen I was also lighter in color, except for a small area almost in the center that was dark red in color (Appendix A, Figure 15b2). The rain ceased by March $6^{\text {th }}$, at which time the specimen became desiccated and tough in appearance. The musculature maintained its dark red/brown coloration, with the fat continuing to be white. The skin had changed in coloration to more yellowed, and the dark red area in the marrow now appeared yellow as well.

On March $7^{\text {th }}$ there was a very light dusting of snow that only partially covered the superior surface of specimen I. The only change on this day, other than the presence of snow, was that some areas of the musculature appeared to have experienced freezer burn (Appendix A, Figure $15 \mathrm{c} 1)$. The snow was completely melted by March $8^{\text {th }}$, at which time it was observed that little change had occurred. The one noticeable change was that the entirety of the specimen appeared more desiccated. The opening in the middle of the specimen also appeared to have begun to close and become hardened (Appendix A, Figure 15c2). Specimen I continued to desiccate into March $15^{\text {th }}$, where the subject appeared almost mummified. By March $16^{\text {th }}$, the one change that occurred was that the marrow began to seep red fluid, which flowed onto the musculature. On March $17^{\text {th }}$, the rain caused the specimen to appear bleached in color, especially around the bone (Appendix A, Figure 15d1). The fat and skin were also white in coloration and stood out in contrast to the darker musculature. Red fluid was no longer seeping from the marrow, and the marrow had also turned white in color with no areas of discoloration. The area in the middle of the musculature appeared much whiter in color and the fat was especially evident. 
By March $18^{\text {th }}$, specimen I had returned to being desiccated. During this time, the middle opening through the musculature had taken on many different colors including yellow, white, and red. One day later, on March $19^{\text {th }}$, the only visible change was that a very small amount of red colored fluid rose to the surface of the bone marrow (Appendix A, Figure 15d2). From the $19^{\text {th }}$ until the $23^{\text {rd }}$ of March, the specimen continued to desiccate, but few other changes were observed. Red fluid continued to flow from the marrow, which eventually flowed onto the musculature of the specimen (Appendix A, Figure 15e1). The middle opening also slowly began to close until it was almost flush with the rest of the musculature. On March $24^{\text {th }}$, approximately 2 inches of snow fell, completely covering specimen I until March $27^{\text {th }}$. On the $27^{\text {th }}$, the specimen was wet and appeared more bleached in overall color. The fat, skin, and marrow all appeared white, while the musculature was fairly dark brown in contrast. A side profile of the specimen (Appendix A, Figure 15e2) showed that it had shrunk in stature and the bone slightly protruded from the musculature. Specimen I continued to be wet due to continued rainfall from March $27^{\text {th }}$ until the $29^{\text {th }}$. During this time, the only change was redder musculature, and the fat, while still basically white, became yellow in the middle opening. Due to the amount of rain, water also began to pool in the middle opening where holes had formed, and during this time, the specimen became especially odorous.

By March $30^{\text {th }}$, the rain had ceased and the specimen appeared more desiccated. The musculature was increasingly redder in color with some areas appearing blackened. The fat surrounding the muscle maintained its white color, while the skin became more yellowed. The opening in the center also began to close off, and the fat in this area was white with some areas of yellow (Appendix A, Figure 15f1). Specimen I began to deepen in color into March 31 ${ }^{\text {st }}$, with 
the majority of the muscle becoming blackened. The marrow also began to emit red fluid, which seeped onto the musculature (Appendix A, Figure 15f2).

\section{April.}

On April $1^{\text {st }}$, less than one inch of snow fell, covering the superior surface of the specimen (Appendix A, Figure 16a1). By the follow day (April $2^{\text {nd }}$ ), a majority of the snow had melted and only a small portion of the superior surface continued to be covered. Specimen I was relatively wet from the melting snow, but did contain some areas that appeared more desiccated. The musculature was dark brown in color, with some areas that appeared blackened. The fat, skin, and marrow were white in color, and looked bleached. There was also a small amount of thick red fluid flowing from the bottom portion of the bone marrow. The rain on April $3^{\text {rd }}$ melted the remaining snowfall, and dulled the coloring of the fat, skin, musculature, and marrow (Appendix A, Figure 16a2). Red fluid was no longer seeping from the bone marrow, and some rain water collected in the middle of the specimen where a hole had developed. By April $4^{\text {th }}$, the only noticeable change was that specimen I was no longer wet, and the musculature appeared dried-out, and the fat was beginning to turn yellow (Appendix A, Figure 16b1). No noticeable change occurred until April $6^{\text {th }}$, when the color of the specimen changed. The musculature became dark red in color and the fat running through the muscle was much lighter in color, making it more noticeable. The subcutaneous fat also remained light in color, and the skin was largely covered by soil that had been splashed on by the rain. The large opening in the center of the musculature also began to change, with the fat in this area becoming more yellow in color, and some of the fat appeared "stringy" (Appendix A, Figure 16b2). It was not until April $9^{\text {th }}$ that there was a visible change, which was largely due to the light snow that fell through the previous night and melted. The saturation of specimen I muted the color of the musculature, fat, skin, and 
marrow. No moisture was present on April $10^{\text {th }}$, and, at this time, the subject was largely desiccated in appearance. The one noticeable change was that a small amount of red fluid had built up on the surface of the bone marrow. By April $11^{\text {th }}$, the amount of fluid flowing from the marrow had increased and there were now two areas which this fluid was emitted from (Appendix A, Figure 16c1). On April 12 ${ }^{\text {th }}$, this fluid had continued to increase in amount, and the majority of the marrow was red with the surrounding area being yellow in color. The musculature of the specimen remained dark, almost blackened, in coloration, and the majority of the fat was now yellow.

By April $14^{\text {th }}$, rain had saturated the specimen, causing it to become bleached in overall color. The red fluid running from the marrow had also been washed away, and there was excess moisture built up in the central opening of the specimen (Appendix A, Figure 16c2). The rain and bleaching continued until April $17^{\text {th }}$, when the specimen returned to appearing desiccated. The musculature returned to being blackened in overall color with streaks of white fat running through it. The fat also began to turn yellow, especially in the large opening running through the musculature. The marrow began to change color with it being more yellowed with areas of dark brown. By the following day (April $18^{\text {th }}$ ), the one noticeable change was that a small amount of red fluid began flowing from the marrow, and this continued into April $19^{\text {th }}$. On this day, there were flies present around and on the specimen. These flies were trying to invade several small holes that had formed in the fat in the central area of the specimen (Appendix A, Figure 16d1). There was also a small amount of red fluid that had accumulated on the marrow, but did not flow onto the muscle. Specimen I continued to appear desiccated into April $20^{\text {th }}$, at which time, the fat appeared much more yellow in color. The marrow also appears to have slightly expanded, and there was still some fluid seeping from this area (Appendix A, Figure 16d2). 
Flies continued to be present on and around the subject, although they could not invade the small openings in the central area. Other insects were also present around the specimen at this time. Visible change did not occur until April $23^{\text {rd }}$, when it rained, saturating the specimen. The rain water from this day pooled in the central area (i.e., where the flies had tried to invade). The fat of the specimen also appeared more diluted in color, with it not being as vibrant yellow as previous days (Appendix A, Figure 16e1). The red fluid continued to be present on the marrow, and it took up the majority of the marrows surface area. On April $24^{\text {th }}$, specimen I returned to being desiccated in appearance, with the musculature looking tough and aged in overall appearance. The fat also returned to being yellow in color, especially around the central opening. The marrow also appeared to have expanded more, and it was more yellow in color. Red fluid continued to be present flowing from the marrow. The $24^{\text {th }}$ was also the first day that maggots were present on the surface of the specimen. They presented themselves in the central opening, running through the musculature, and were extremely small $(<1 / 4$ inch) and hardly visible (Appendix A, Figure 16f1). By April 26 ${ }^{\text {th }}$, the holes in the central opening appeared to have widened, although there were no maggots present on this day. The fat surrounding the musculature and running throughout the central opening was visibly wet (e.g., likely due to decompositional fluids). The marrow at this point was also expanded, and much darker in color. On April $27^{\text {th }}$, the most noticeable change was that there appeared to be excess moisture seeping from areas of the specimen, including the central opening, and a small area underneath the bone (Appendix A, Figure 16g1). When looking inside the holes in the central opening, it was apparent that moisture had accumulated internally. Moisture was also accumulating underneath the specimen, with the ground becoming saturated. Liquid continued to be emitted from specimen I into April $30^{\text {th }}$. This liquid appears to come from the central opening, and areas where 
there is fat (Appendix A, Figure 16g2). The majority of the superior surface is now covered by some light moisture.

\section{May.}

Fluids continued to be emitted from specimen I into May $1^{\text {st }}$, at which time, there appeared to be a large area of fluid pooling underneath the entire specimen, as well as on the subject underneath the bone. There was also one maggot that was easily visible on the external surface of the specimen (Appendix A, Figure 17a1). By May $2^{\text {nd }}$, there was little change in the appearance of the specimen and the maggot that had been observed the previous day did not appear to be alive any longer (Appendix A, Figure 17a2). On May $3^{\text {rd }}$, the rain during the day had bleached the coloration of the specimen. The fat was now white, and the musculature continued to be dark in color, but had turned redder. The marrow at the cross-section also seems to have collapsed inward, creating a more concave shape (Appendix A, Figure 17b1). Moisture also pooled in the central opening, and it did not appear as though there were any maggots present at this time. The following day, May $4^{\text {th }}$, specimen I returned to being desiccated. No maggots were visible, and the one change was that the fat appeared much more yellow in coloration, and the musculature returned to being blackened. The only change that occurred from the $4^{\text {th }}$ until May $5^{\text {th }}$, was that a hole was created in the center of the marrow (Appendix A, Figure 17b2). Fluid also continued to be emitted underneath the specimen, causing the soil to become wet. From May $5^{\text {th }}$ until the $10^{\text {th }}$, the visible changes included the darkening of the musculature, and the fat and marrow continued to be yellow in color. Fluids continued to be emitted from underneath the specimen, the central opening, and the fatty areas surrounding the musculature. This fluid covered almost the entire superior surface, making the specimen appear 
wet. On May $7^{\text {th }}$, a small maggot mass had formed near the ground surface underneath the specimen (Appendix A, Figure 17c1), but had dissipated by May $8^{\text {th }}$.

On May $11^{\text {th }}$, specimen I was removed from under cage 5, at which time it was closely examined. Specimen I was heavily desiccated, with the musculature being dark in color and having an aged, toughened appearance (Appendix A, Figure 18a1). The fat surrounding the specimen was yellow, and the skin was covered in soil making it difficult to determine its actual coloration. The central area, which was mostly fat, had maintained its yellow coloring and the distal end of this area had turned green in color (Appendix A, Figure 18a2). There was also moisture being emitted from the central opening, causing the musculature to have a sheen across it. This liquid had also seeped into the soil, making it wet. The marrow continued to be yellow in color with a large area of dried red fluid in the center, and the hole still being present through the marrow (Appendix A, Figure 18b1). A profile view of the specimen showed that it had shrunk, with the bone protruding from the musculature (Appendix A, Figure 18b2). Due to these decompositional changes, specimen I was categorized as being in an advanced state of decomposition (Figure 12).

When the specimen was lifted from the cage, it was observed that it had left a pool of moisture on the ground surface. There were also some areas where the flesh of the specimen had stuck to the ground and remained on the soil surface (Appendix A, Figure 18c1). The inferior surface of the specimen was viscous in consistency and almost entirely covered in wet soil (Appendix A, Figure 18c2). There were some areas of musculature and fat that were visible, and they were diluted in color (i.e., light pink and white).

After removal from cage 5, specimen I was weighed and measured. The subject had decreased in weight by 3.1 pounds to weigh a total of 4.7 pound and measured 25 inches in 
circumference. The musculature was tough and no impression was left when it was touched or handled. The fat on the superior surface was also tough, although was not as hardened as the musculature. The inferior (laying on ground surface) side of specimen I had become almost liquefied and was more difficult to handle compared to the superior side. Throughout the examination, flies were present on and around the specimen. There did not appear to be any maggots on or inside of specimen I, although an internal examination was not conducted due to the advanced desiccation of the subject. During the examination, there was also a pungent odor emitted from the specimen, which became amplified when the subject was removed from within cage 5 .

\section{Insect Infestation}

March $9^{\text {th }}$ was the first day that flies were observed in the area surrounding the study site. Only two flies were present and remained around the pig proxies while examinations were being conducted. However, no insects were present on any of the specimens prior to exposure to the surface, or taken out of their respective cages on March $9^{\text {th }}$. After this initial date, insects were not observed on the surface remain (specimen I) until April $20^{\text {th }}$. On this day, flies were present on the external surface of the air-exposed remains, and were attempting to burrow themselves within the musculature of the subject. Upon closer inspection, there were also some much smaller, gnat-like, believed to be a non-insect hexapod species known as a springtail, crawling across the surface of the remains. Fewer insects were present on April $21^{\text {st }}, 22^{\text {nd }}$ and $23^{\text {rd }}$, with no fly's present, and the majority of insects observed were gnat-like. By April $24^{\text {th }}$, maggots became visible on the surface of specimen I (see Appendix A). The maggots present, were very small $(<1 / 4$ inch) and could be seen trying to invade the internal portion of the specimen. On April $25^{\text {th }}$, the maggots were no longer as easily visible, and had inserted themselves further into the 
internal musculature. From April $26^{\text {th }}$ until April $30^{\text {th }}$, no maggots were observed on the external surface or within the internal musculature. There were also no flies present during this time, although there were some springtails present on April $29^{\text {th }}$.

On May $1^{\text {st }}$, there was one large maggot present on the external surface of specimen I (see Appendix A), but by the following day (May $2^{\text {nd }}$ ), it appeared as though it had died. By May $3^{\text {rd }}$, no maggots were present on the external surface of the subject, and this continued to the completion of this study. The internal surface, which could be observed via holes formed in specimen I, shows that some maggots were inhabiting this area on May $3^{\text {rd }}$. It was not until May $7^{\text {th }}$ when maggots were observed again on specimen I. At this time, a small maggot mass had formed close to the ground surface, underneath the specimen (Figure 28). By May $8^{\text {th }}$, the majority of these maggots had disseminated, but it is unknown where they had gone, and only a few were visible (Figure 29). Flies were present on May $5^{\text {th }}$, although they did not land on the surface of the subject. This same observation was made from May $6^{\text {th }}$ until May $8^{\text {th }}$, on which day the subject was visited by other insects, including beetles and pill bugs. On May $9^{\text {th }}$, there were infant flies present on and around specimen I. The presence of these flies was also observed on May $10^{\text {th }}$. On the examination date (May $11^{\text {th }}$ ), an abundance of infant and adult flies was present throughout the examination of specimen I, along with the remaining specimens $(\mathrm{C}, \mathrm{D}, \mathrm{G}$, $\mathrm{H})$. 


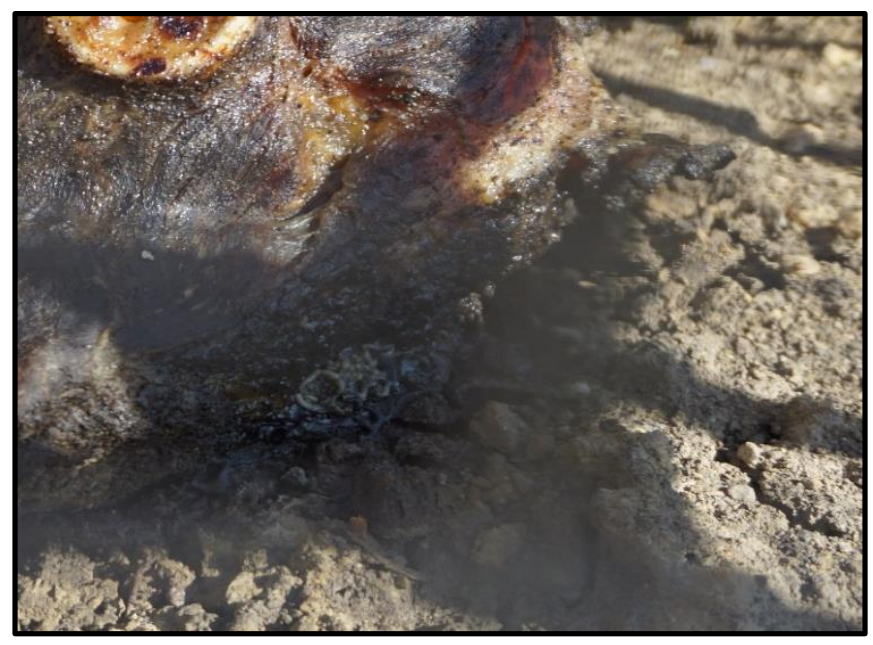

Figure 28. Small maggot mass forming underneath the specimen in the decompositional fluids.

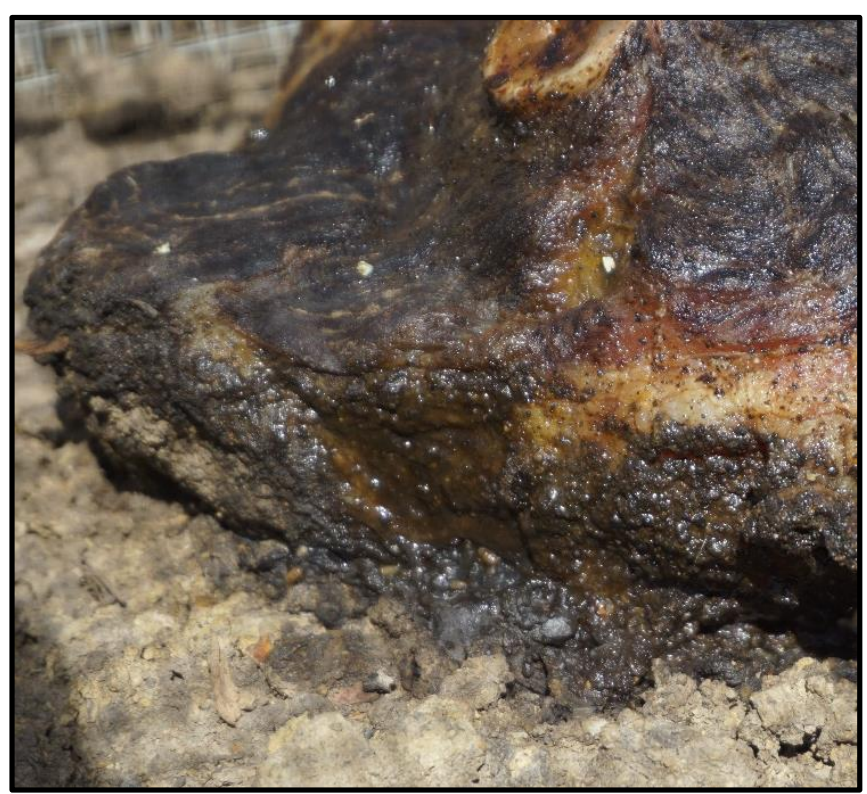

Figure 29. Maggots mass has diminished since the previous day (May 7, 2018).

No maggots were present on the external or internal surface of specimen I when it was examined on May $11^{\text {th }}$. There were also no maggots on the ground surface when specimen I was removed from within cage 5 . Specimen $\mathrm{D}$ (white cotton t-shirt at 6inches) was the first buried specimen to be unearthed on May $11^{\text {th }}$. As the t-shirt was being removed from the subject, it 
observed that maggots ( 1/4 inch) were present throughout the t-shirt (Figure 30), but were not observed on the surface of the specimen. Specimen C (white cotton t-shirt at 18inches) also had maggots $(<1 / 4$ inch) present on the t-shirt (Figure 31$)$. Maggots were observed on the surface of the t-shirt, as well as throughout the layers of the shirt. These maggots were numerous, and it is unknown how many were actually present. No maggots were observed on the surface of specimen $\mathrm{C}$, when the $\mathrm{t}$-shirt was partially removed. Maggots were not observed within the plastic garbage bags, or on the external surface of specimens $\mathrm{G}$ and $\mathrm{H}$ on May $11^{\text {th }}$.

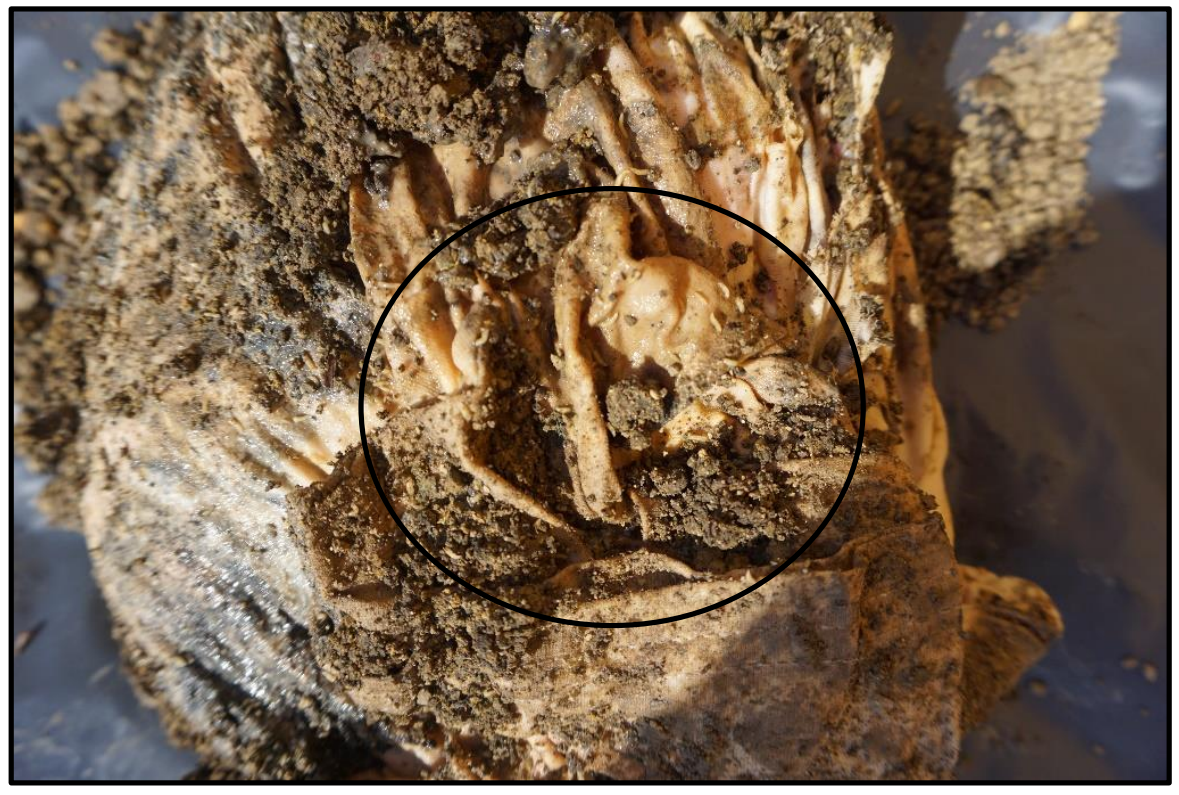

Figure 30. Maggots on the surface of the t-shirt covering specimen $\mathrm{C}$ during the four-month examination. 


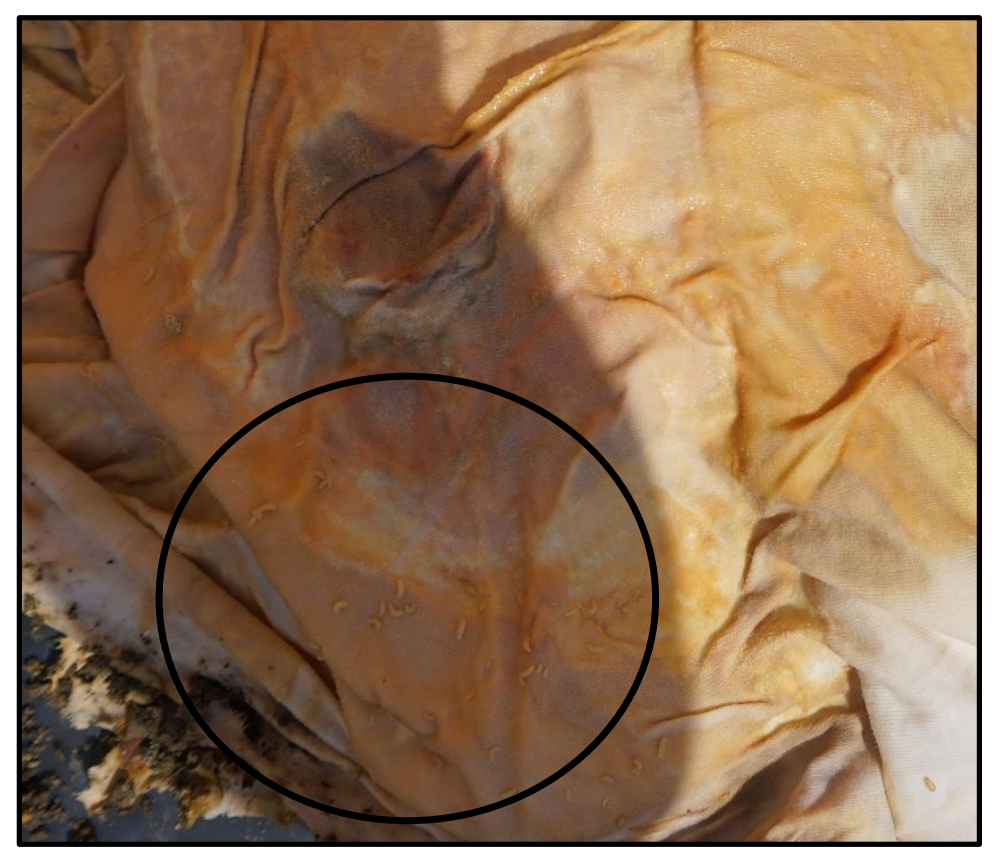

Figure 31. Maggots within the t-shirt layers of specimen $\mathrm{C}$ on the four-month examination date (May 11, 2018).

\section{Soil Analysis}

A soil test report from A\&L Great Lakes Laboratories was received after soil samples were sent at the beginning of the study. This report provided information about the soil composition from depths of 6 and 18 inches in the ground (Table 5). The percent of organic matter for both soil samples (6 inches and 18 inches) was $2.9 \%$, which falls just below the optimum percentage of 3 to 5 percent (Hazelton \& Murphy, 2016; Horneck, Sullivan, Owen, \& Hart, 2011; Spargo, Allen, \& Kariuki, 2013; Wroth, 1984). The amount of phosphorus in the soil at 6 inches fell in the medium range of amount of phosphorus at 28ppm (parts per million). The soil sample from a depth of 18 inches concluded that the amount of phosphorus was very low $(<20)$ at only $5 \mathrm{ppm}$. The amount of potassium for both soil samples were in the optimum range, with the sample at 6 inches having 136ppm, and at 18 inches, 112ppm. Magnesium in both soil 
samples was high, with the 18-inch soil sample containing a very high amount of magnesium (705ppm). The 6-inch soil sample contained 485ppm of magnesium. The amount of calcium in the soil from the 18 -inch sample was considered to be in the optimum range, at 2,550ppm. Calcium in the 6-inch sample was considered high, with it containing 3,150ppm. The soil $\mathrm{pH}$ for both soil samples ran only slightly above neutral (7.0), with it being 7.6 at 6 -inches, and 7.3 at 18-inches. The Cation Exchange Capacity (CEC) as recorded at 20.1 for the sample taken at 6 inches, and 18.9 for the sample at 18 inches (Table 5). This reading (15-25) revealed that the soil collected had a heavier concentration of clay. Table 5 also recorded the percentage of nutrient (potassium, magnesium, and calcium) found in each soil sample. 
Table 5

Soil Composition from Samples Taken at 6 and 18 inches Below the Soil Surface

\begin{tabular}{|c|c|c|c|c|c|c|c|c|c|c|}
\hline \multirow[t]{2}{*}{ Soil Sample } & \multirow[t]{2}{*}{$\begin{array}{l}\text { Organic } \\
\text { matter \% }\end{array}$} & \multirow{2}{*}{$\begin{array}{c}\text { Phosphorus } \\
\text { Bray-1 Equix } \\
\text { ppm-P }\end{array}$} & \multirow[t]{2}{*}{$\begin{array}{c}\text { Potassium } \\
\text { ppm }\end{array}$} & \multirow[t]{2}{*}{$\begin{array}{c}\text { Magnesium } \\
\text { ppm }\end{array}$} & \multirow[t]{2}{*}{$\begin{array}{c}\text { Calcium } \\
\text { ppm }\end{array}$} & \multirow[t]{2}{*}{$\begin{array}{l}\text { Soil } \\
\text { pH }\end{array}$} & \multirow[t]{2}{*}{$\begin{array}{c}\text { CEC } \\
\mathrm{meg} / 100 \mathrm{~g}\end{array}$} & \multicolumn{3}{|c|}{$\begin{array}{c}\text { Percent Cation } \\
\text { Saturation }\end{array}$} \\
\hline & & & & & & & & $\% \mathrm{~K}$ & $\% \mathrm{Mg}$ & $\% \mathrm{C}$ \\
\hline 6 inches & 2.9 & 28 & 136 & 485 & 3150 & 7.6 & 20.1 & 1.7 & 20.1 & 78.2 \\
\hline 18 inches & 2.9 & 5 & 112 & 705 & 2550 & 7.3 & 18.9 & 1.5 & 31.1 & 67.4 \\
\hline
\end{tabular}




\section{CHAPTER V: DISCUSSION}

Partial pig remains (Sus scrofa), containing bone, bone marrow, muscle, fat, and skin were used in place of human cadavers or complete pig specimens. Due to the size and location of the study area, it was pertinent to study as many specimens as possible, in a variety of settings. Pigs are often used in place of human subjects due to anatomical, physiological, and enteric bacterial colony similarities. However, it is suggested the pig proxies should weigh at least 50.7 pounds for research purposes (Campobasso et al., 2001; Goff, 1993; Notter, Stuart, Rowe, \& Langlois, 2009; Roberts \& Dabbs 2015; Schoenly, Haskell, Mills, Bieme-Ndi, \& Yer Lee, 2006). However, the restricted testing circumstance precluded samples of that size and weight. The size and composition of the partial specimens used in this study are argued to be similar to disarticulated elements of a human cadaver.

Winter conditions of central Illinois evidently produce variations in the decomposition process of partial pig (Sus scrofa) specimens, depending on the type of coverings (i.e., cotton tshirt, plastic garbage bag) and environment (i.e., buried at various depths, or on the ground surface) they are subject to. Cold temperatures (e.g., freeze-thaw) and weather conditions (e.g., precipitation, insulating effect of snow cover) of the ground surface specimens (i.e., I \& J) retarded the amount of overall decomposition. The decrease in decomposition could also largely be due to the reduced amount of insect activity throughout the four-month observation period. It was observed that the specimens buried at 18 inches below the ground surface (i.e., A, C, E, G) decomposed at a much more rapid rate than those specimens buried at only 6 inches (i.e., B, D, $\mathrm{F}, \mathrm{H})$. The rate of decomposition was also accelerated in remains buried in white cotton t-shirts

(i.e., A, B, C, D) compared to the specimens wrapped in plastic garbage bags (i.e., E, F, G, H). In 
sum, during the two- and four-month intervals (January-May), the specimens with the greatest amount of decomposition were those buried at 18 inches, wrapped in cotton t-shirts (A \& C). Subject $\mathrm{C}$ also had an extensive number of maggots present during the May $11^{\text {th }}$ examination.

The specimens with the greatest amount of preservation were those wrapped in plastic garbage bags and buried at 6 inches beneath the ground surface (i.e., F \& H). Even after being buried for two and four months, each of the subjects wrapped in plastic garbage bags (i.e., E, F, G, \& H) maintained their overall shape and appeared markedly less decomposed.

\section{How Cold Weather Affects Remains}

In previous studies (Micozzi, 1986; Roberts \& Dabbs, 2015; Zuigibe \& Costello, 1993), where previously frozen animal (i.e., pigs and rats) and human remains were allowed to naturally thaw, it was observed that the subjects decomposed from the "outside-in," compared to the normally observed "inside-out." Cold weather studies (e.g., Bunch, 2009; Komar, 1998) found that remains left to decompose during winter months were better preserved than subjects who had been found at any other time during the year. The general conclusions are that freezing $\left(32^{\circ} \mathrm{F} / 0^{\circ} \mathrm{C}\right)$ and below freezing $\left(<32^{\circ} \mathrm{F} / 0^{\circ} \mathrm{C}\right)$ temperatures inhibit insect, animal, and bacterial activity (Byers, 2017; Dix \& Graham 2000; Mann et al., 1990; Roberts and Dabbs 2015).

In comparison with previous studies, the current assessment concluded that when remains are subject to cold temperatures and weather conditions on the ground surface, remains will decompose from the "inside-out". The external surface becomes desiccated, while the internal structure liquefies. Due to the cold temperatures, which led to desiccation, the surface specimens remained intact with relatively minimal decompositional changes. However, previous studies (Bunch, 2009; Komar, 1998; Micozzi, 1986; Roberts \& Dabbs, 2015; Zugibe \& Costello, 1993) 
have not been conducted to assess how remains decomposed at specific depths or in various coverings.

Temperatures at or below $37^{\circ} \mathrm{F} / 2.8^{\circ} \mathrm{C}$ were considered "cold temperatures" for the purposes of this study (i.e., within the recommended rage of $35^{\circ} \mathrm{F}-38^{\circ} \mathrm{F}\left[1.7^{\circ} \mathrm{C}-3.3^{\circ} \mathrm{C}\right]$ for the preservation of refrigerated goods) (Cunningham \& Bowers, 1977; Zhao, Shu, Fan, Cao, \& Jiang, 2018). Of the 123 study days, 90 of those days experienced low temperatures that were recorded at or below $37^{\circ} \mathrm{F}$. Temperatures at or below freezing $\left(32^{\circ} \mathrm{F} / 0^{\circ} \mathrm{C}\right)$ were also recorded for 74 days as the low daily temperature. For the high daily temperature, there were a recorded 34 days that experienced temperatures at or below $37^{\circ} \mathrm{F} / 2.8^{\circ} \mathrm{C}$, and 18 days where the high for the day was at or below $32^{\circ} \mathrm{F} / 0^{\circ} \mathrm{C}$. By January $12^{\text {th }}$, the low temperatures caused the ground surface specimens to become freezer burned, with the external surface appearing hardened and rough in texture. At only three days into the study, specimens I and $\mathrm{J}$ had already started to become desiccated. These cold temperatures allowed for greater preservation to the specimens on the ground surface (I \& J).

Specimens buried at 6 inches and 18 inches experienced a greater degree of decomposition from January to May, which contradicts other studies on buried remains (Campobasso et al., 2001; Rodriguez \& Bass, 1985; Simmons, Cross, Adlam, \& Moffatt, 2010; Wilson et al., 2007). In warmer temperatures, buried human remains were documented to decompose at a much slower rate than those placed above ground (Campobasso et al., 2001; Rodriguez \& Bass, 1985). The soil surrounding buried remains provides an insulative barrier against direct sunlight and higher temperatures during warmer months, creating a cooler environment, decreasing the rate of decomposition. The opposite was observed in the present study, where buried remains decomposed at a much more rapid rate than those on the ground 
surface. In the winter months, the soil continues to be an insulative barrier against cold temperatures and weather conditions, but the deeper remains are buried, the warmer temperatures become (Minsany, Stockmann, Hartemink, McBratney, 2016; Wendland, 1998). At the time of exhumation, subjects buried at 18 inches were at a much more advanced stage of decomposition compared to specimens on the ground surface and at the 6-inch depth.

\section{Decompositional Differences between Specimens}

\section{Specimens $A$ and $C$}

Specimens $\mathrm{A}$ and $\mathrm{C}$ were both buried at 18 inches below the ground surface in white cotton t-shirts. On March $9^{\text {th }}$, specimen A was exhumed for decompositional changes. At this time, the subject was in the late stage of early decomposition, with the musculature losing its shape and form, and the color becoming much more muted (Figure 32a). On May $11^{\text {th }}$, specimen $\mathrm{C}$ was exhumed and observed for decompositional changes. Specimen $\mathrm{C}$ was much further decomposed after an additional two months of decomposition (Figure 32b); it was almost completely liquefied. It was difficult to discern the separate parts of the specimen (i.e., musculature, skin, fat) due to this advanced state of decay. The skin was no longer surrounding the specimen and could not be located or identified. The bone had also become dislodged from the internal musculature, and was on the laying on the surface of the remains once the t-shirt was unwrapped. Specimen $\mathrm{C}$ was also incredibly difficult to handle compared to specimen A. The amount of liquefaction that had occurred made analyzing this specimen increasingly difficult, whereas specimen A could be somewhat easily manipulated. The coloration of this subject was also slightly muted, although the musculature was still pink in color. 


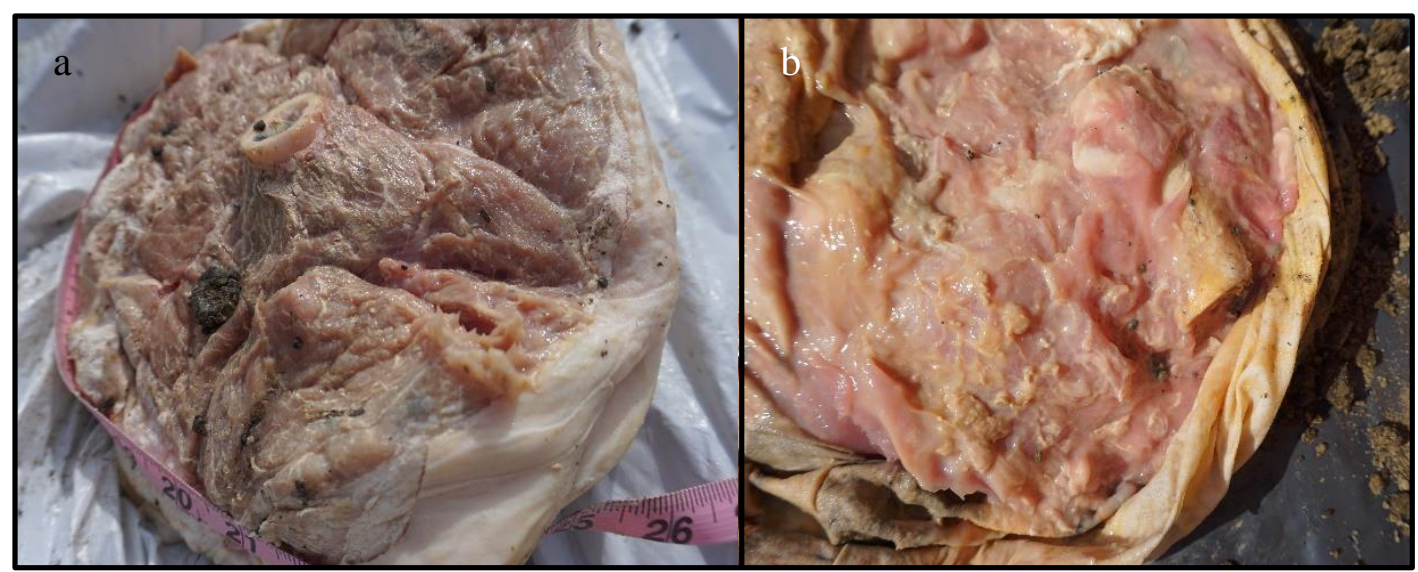

Figure 32. Clothed in white cotton t-shirts and buried at 18 inches: a) Specimen A after two months of decomposition; b) Specimen C after four months of decomposition.

Other major differences included the preservation of the t-shirt. After two months, specimen A had no major changes to its covering. The decompositional fluids had caused the tshirt to become more yellow in coloration. While this was also observed at the four-month observation period to specimen $\mathrm{C}$, there was also breakdown of the $\mathrm{t}$-shirt fabric, causing holes to form. Specimen $\mathrm{C}$ also had maggots present throughout the external surface of the covering. No maggots were present during the examination of specimen A. Specimen A had also decreased in weight, but increased in circumference. This could largely be due to the amount of tissue breakdown, causing the form of the specimen to expand and settle over time. Specimen $\mathrm{C}$ had also decreased in weight, although there are some discrepancies since the t-shirt could not be removed due to the amount of decomposition. The advanced rate of liquefaction also did not allow for the circumference to be recorded.

\section{Specimens B and D}

Specimens B and D were both covered in white cotton t-shirts and buried at 6 inches below the ground surface. On March $9^{\text {th }}$, specimen B was observed for decompositional changes 
that occurred throughout its two-month burial. The specimen remained intact, with the musculature beginning to break down, and the coloration of the entire specimen being more dulled or muted (Figure 33a). Specimen B was categorized as being in the early stages of decomposition, with the majority of the subject still appearing relatively fresh. After the fourmonth interval, on May $11^{\text {th }}$, specimen D was observed for decompositional changes. At this time, the subject was in an advanced state of decomposition. The musculature and fat were beginning to liquify, although the skin still remained intact around the specimen (Figure 33b). The bone inside the subject was also quite loose, and could be easily moved. The coloration of this subject had also become somewhat muted, with the musculature still maintaining its pinkish coloring. There were also some maggots present on the t-shirt during the time of examination.

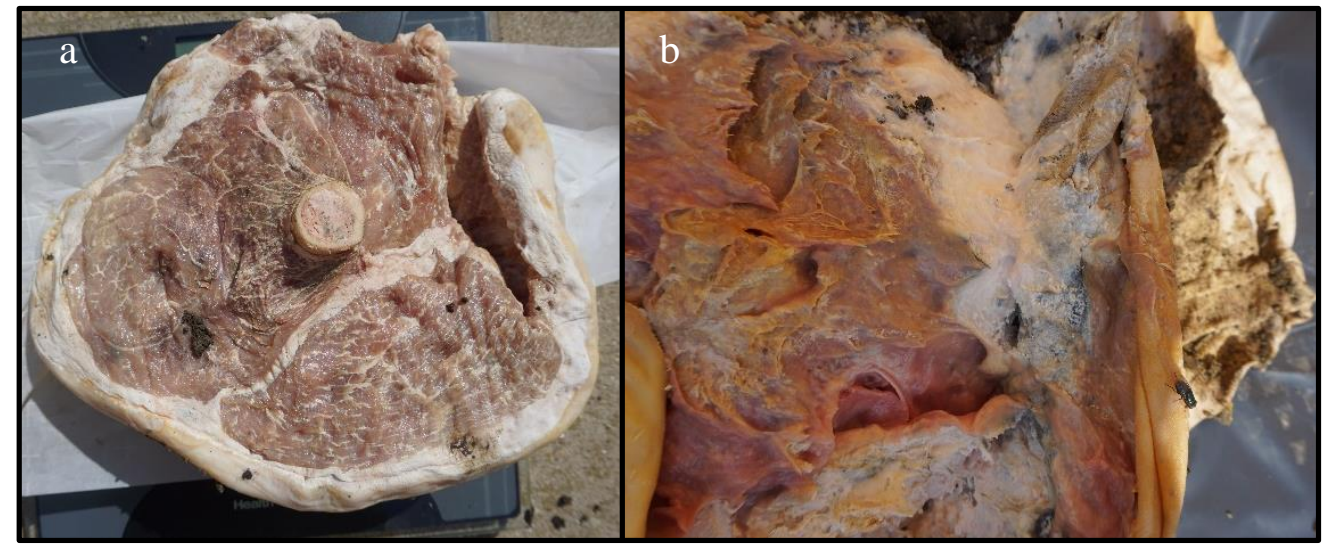

Figure 33. Clothed in white cotton t-shirts and buried at 6 inches: a) Specimen B after two months of decomposition; b) Specimen D after four months of decomposition.

The t-shirt surrounding specimen B had not started to deteriorate, but there were some yellow stains caused by decompositional fluids. These yellow stains were also observed on the tshirt covering specimen D, but on a much larger scale. Specimens D's covering had begun to 
deteriorate, with holes forming along the armbands and the sides of the shirt. While there were maggots on the t-shirt at the time of examination of specimen D, specimen B had no maggots present during its examination. Specimen B decreased in weight after two-months, but the circumference remained the same. Similar to specimen C, subject D decreased in weight, although there are some discrepancies since the t-shirt could not be removed due to the advanced stage of decomposition. The circumference could also not be taken because the specimen had begun to liquify.

\section{Specimens E and G}

Specimens E and G were both buried at 18 inches and wrapped in a plastic garbage bag. After two-months within the ground, specimen E was examined on March $9^{\text {th }}$ for decompositional changes. Upon removal from the garbage bag, it was observed that specimen $\mathrm{E}$ was relatively well preserved and in the late stage of early decomposition. The skin was intact, and the musculature had kept its overall shape and form. One noticeable difference was that the musculature had begun to change color from pinkish-red to more brown in coloration (Figure 34a). The skin had also taken on a pinker hue, likely due to the amount of decompositional fluids accumulating within the garbage bag. After an additional two-months of burial, specimen $\mathrm{G}$ was examined on May $11^{\text {th }}$. Specimen $\mathrm{G}$ was in an advanced stage of decomposition, but the subject still appeared to be fairly well preserved. The skin was still surrounding the musculature, although the musculature and skin had begun to break down and was becoming more liquefied (Figure 34b). The color of the musculature was also muted, and had become browner in coloration compared to specimen E at the two-month interval. Specimen G also had a fair amount of decompositional fluids that that had accumulated within the garbage bag. 


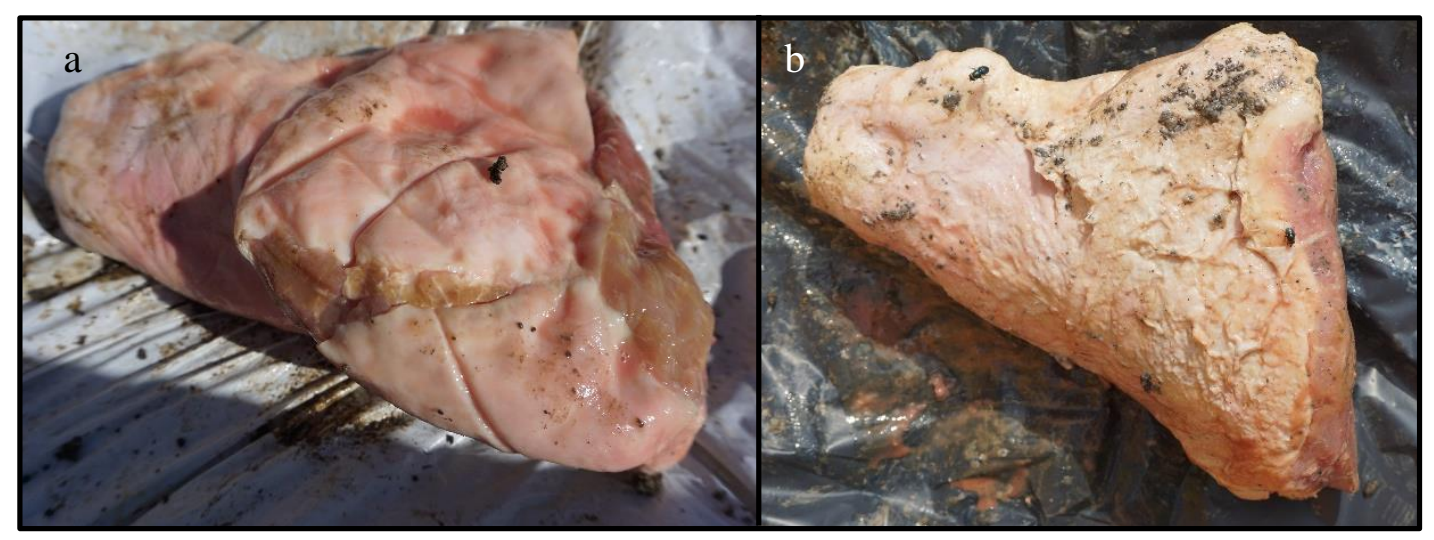

Figure 34. Specimens in garbage bags and buried at 18 inches: a) Specimen E after two months of decomposition; b) Specimen G after four months of decomposition.

Specimen E had decreased in both weight and circumference, whereas specimen $\mathrm{G}$ had decreased in weight, but its circumference had increased. This could be due to the amount of breakdown the subject had experienced over the four-month period, allowing the musculature to expand and settle. Neither one of the specimens had maggots or insect present within the garbage bag or in the surrounding area where the specimens were buried. No breakdown was observed to the garbage bags.

\section{Specimens $\mathbf{F}$ and $\mathbf{H}$}

Specimens $\mathrm{F}$ and $\mathrm{H}$ were both buried at 6 inches under the ground surface and wrapped in plastic garbage bags. On March $9^{\text {th }}$, specimen $\mathrm{F}$ was examined for decompositional changes. Decompositional fluids were present within the garbage bag. Upon exhumation, it was observed that the specimen was between the fresh to early stages of decomposition. That is, the skin, muscle, bone, and fat were all still intact and the subject had maintained its overall shape and form (Figure 35a). The major changes were that the musculature became browner in color and the external and internal surface of the bone had also turned bright red in color. 
Specimen $\mathrm{H}$ was examined on May $11^{\text {th }}$, and during this time it was observed that the subject was in the early stages of advanced decomposition. The overall shape and form of specimen $\mathrm{H}$ was well preserved, but the musculature had become much browner in color and was not muted like what was observed in specimen F (Figure 35b). The external and internal surface of the bone was also not as specimen $\mathrm{F}$ at the two-month interval. The skin of specimen $\mathrm{H}$ was still intact, and the musculature had begun to breakdown, but not falling apart.

Both specimen $\mathrm{F}$ and $\mathrm{H}$ had some decompositional fluids accumulate within their respective garbage bags. No maggot or insect activity was present within either garbage bag or were observed within the soil where the remains were buried. Specimen F had decreased in weight and circumference over the course of two months. This was also the case for specimen $\mathrm{H}$, which had decreased in weight and circumference after being buried for four months.

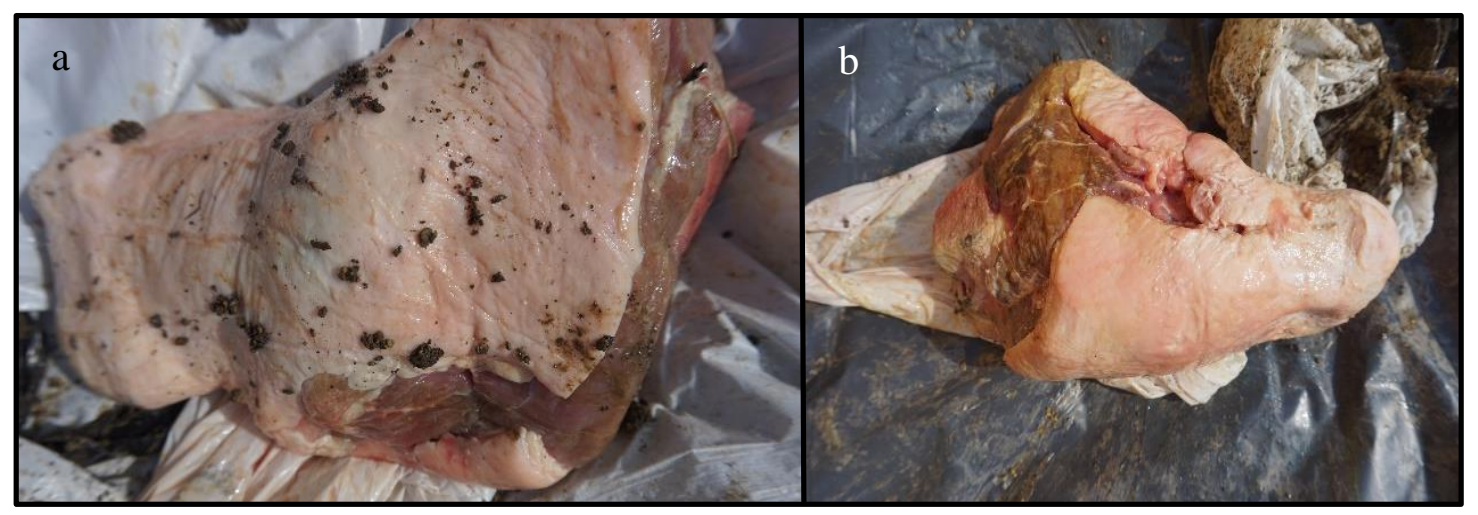

Figure 35. Specimens wrapped in garbage bags and buried at 6 inches: a) Specimen F after two months of decomposition; b) Specimen $\mathrm{H}$ after four months of decomposition.

\section{Specimens I and J}

Specimens I and J were both left uncovered and placed on the ground surface. Both subjects were examined daily throughout the two and four-month periods. On March $9^{\text {th }}$, 
specimen $\mathbf{J}$ was removed from the ground surface and examined. The external surface of specimen J had become desiccated, with a leathery, hardened exterior (Figure 36a). The fat had also become hardened, and was almost waxy in texture. The overall coloration of specimen $\mathrm{J}$ had also changed. The musculature was now a dark brown/red, the skin had become yellow with some areas that appeared pink. The bone marrow had also changed color from white to a mixture of brown, grey, and red. The underside of specimen J, which had been in contact with the ground surface, was wet.

After four-months, specimen I was examined on May $11^{\text {th }}$. Specimen I was much further desiccated than specimen $\mathrm{J}$ had been after two months. The musculature was almost blackened, and was rough and leathery in texture (Figure 36b). The fat within and surrounding the specimen had turned an intense shade of yellow, with some areas appearing green. The skin had also turned yellow and was desiccated. Yellow coloring was also observed to the bone marrow to specimen I, although there were also some areas of dark brown where red fluid had seeped from the marrow.

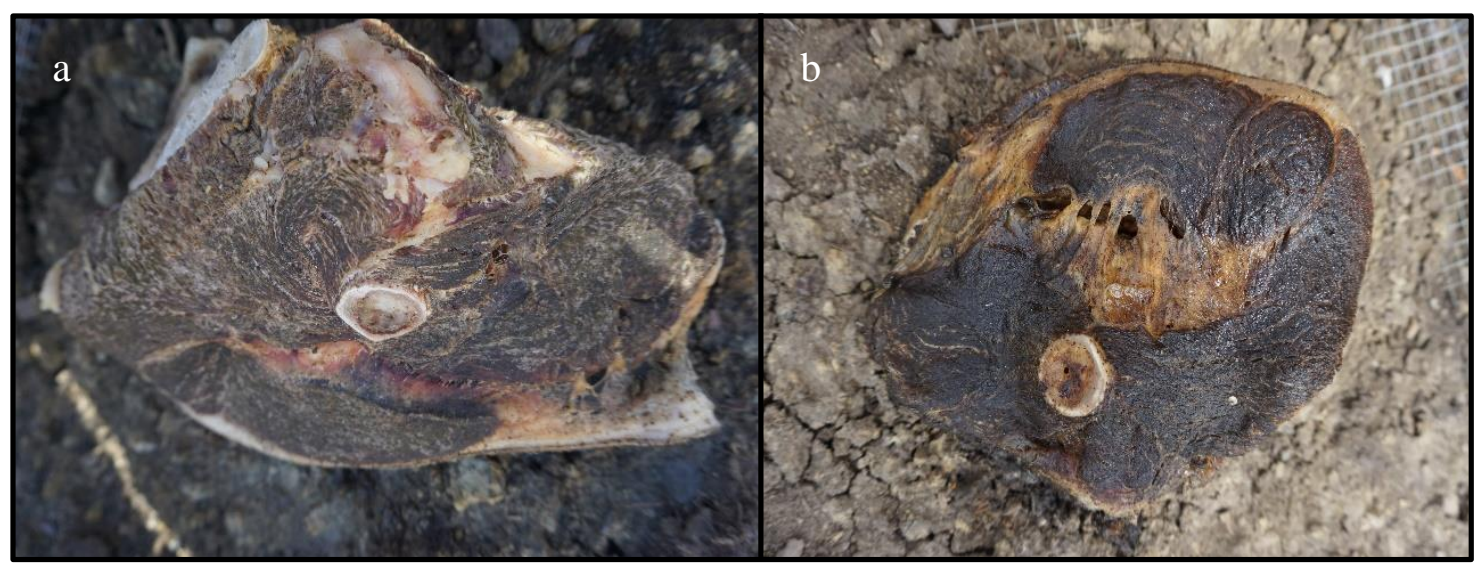

Figure 36. Specimens left exposed on the ground surface: a) Specimen J after two months of decomposition; b) Specimen I after four months of decomposition. 
Specimen I had also started to break apart, with the fat running through the musculature forming holes for insect to enter. During this study, maggots and other insects were observed on the external and internal surfaces of specimen I, although they were not observed on the actual day of examination. No maggots or insects were observed before or on the examination date for specimen J. Specimen I also had a large amount of decompositional fluid accumulating on the ground surface, which was not observed during the two-month examination of specimen I. When specimen I was removed from the ground surface, a large area of fluid and decomposed flesh was left on the soil surface. The underside of the specimen was also much further decomposed; the musculature was liquefied, and the soil stuck to it. Specimen $\mathrm{J}$ had decreased in circumference, but increased in weight. It is speculated that this increase is due to the specimen being frozen from the cold temperatures, as well as soil freezing to the specimen after it was removed from the ground surface. Specimen I had decreased in both weight and circumference.

\section{Garbage Bag vs. T-shirt}

Subjects wrapped in plastic garbage bags and buried beneath the ground surface decomposed at a dramatically slower rate than what was observed in the clothed specimens. Even after four months, the specimens placed in garbage bags were well preserved and maintained their overall form without becoming completely liquefied. The degree of preservation experienced by these specimens is due to a restriction of oxygen surrounding the remains (Dautartas, 2009; Mant, 1987). When the subjects were originally placed and wrapped in the garbage bags, air was manually compressed out of the bags before their placement within the ground. After two and four months, it was evident that little air was in the garbage bag due to how tightly the bag was compressed against the specimens. Human remains have been placed in plastic garbage bags or tarps (Dautartas, 2009; Zugibe \& Costello, 1993) when a perpetrator tries 
to dispose of the remains. These bags can conceal the location of the remains, and make it difficult for insects, carnivores, and scavengers to access the remains. In this study, placing remains in a garbage bag and burying them in the winter slows the rate of chemical decomposition. This decelerated rate of decomposition would allow law enforcement to identify the remains with greater ease.

The subjects wrapped in white cotton t-shirts and buried within the ground decomposed at a comparatively faster rate. After two months, the specimens unearthed had started to breakdown and liquefy. By the four-month interval, the subjects had almost completely liquefied, losing their overall shape and form. While there is disagreement about how clothing affects the decomposition process (Aturaliya \& Lukaswycz, 1999; Cahoon, 1992; Campobasso et al., 2001; Gonzales et al., 1954; Haglund, 1989; Kelly et al., 2009; Matuszcwski et al., 2014; Miller, 2002), it was observed in this study that clothing accelerates the decomposition process. At both examination dates, the t-shirt seemed to be the only factor holding together the remains, whereas the subjects within the garbage bags maintained their form without the aid of its wrappings. Maggots could still gain access to the clothed remains, even though they were buried within the ground. Small maggots $(<1 / 4$ inch) were present on the t-shirts covering specimens $\mathrm{C}$ and D.

The cotton t-shirt allowed for decompositional fluids from the specimens to seep through the shirt and into the soil. This fluid could be observed as the clothed specimens were unearthed, and this was not observed for any of the specimens wrapped in garbage bags. Instead, those specimens placed in garbage bags preserved these fluids within the bag and were not allowed to seep into the ground. It is unknown if the high degree of decomposition in clothed remains in due 
to an increase in temperature from the t-shirt (i.e., insulation), since internal temperatures were not taken from the remains at the time of examination.

\section{Buried vs. Surface}

Subjects placed uncovered on the ground surface are subject to environmental factors that buried remains do not experience. Throughout the four-month period, the surface remains were subject to direct sunlight, wind, humidity, snowfall, rainfall, frost, and undoubtedly other factors. The most noticeable change to the surface specimens (I and J) was that the external surface of the remains became desiccated, likely due to evaporation. This caused the musculature and skin to become somewhat mummified, with a leathery and hardened exterior. The process of desiccation began early within this study, and continued until the four-month examination date. Early desiccation included freezer burn forming on the exposed musculature surfaces.

Environmental factors like rain and snowfall caused specimen I and J to become saturated. When this occurred, the rate of decomposition seemed to hasten, although, the remains quickly became dried-out when the weather conditions returned to normal (i.e., no snow/rain, low humidity). While the air exposed surface was subject to direct environmental conditions, the surface in direct contact with the soil deteriorated much more rapidly. At the two-month examination date, this surface of specimen $\mathrm{J}$ had started to decompose, with fluids seeping from the specimen in this area, as well as it being more wet than the remainder of the specimen. After four months, the surface in direct contact with soil was much further decomposed than the superior surface. This area of specimen I was becoming liquefied, and soil clung to it. Maggots only became apparent after the two-month examination date, but none could be located on or around specimen I during the four-month examination. 
While no buried subjects were placed uncovered beneath the ground surface, comparative data can still be drawn between these sets of remains. As previously stated, subjects wrapped in cotton t-shirts decomposed at a much more rapid rate than those specimens buried in plastic garbage bags. However, all specimens buried at 18 inches experienced more advanced decomposition than those at 6 inches. During the winter months, temperatures increase as burial depth increases (Brown \& DeGaetano, 2011; Coulson et al., 1995; Minasny et al., 2016; Wendland, 1998). This is due to temperatures being more constant (i.e., linear) as soil depth increases, as well as cold temperatures and frost not penetrating greater depths (i.e., up to 18 inches) (Wendland, 1998). The opposite affect had been recorded in the summer months, where deeply buried remains decompose much more slowly due to cooler temperatures (Carter et al., 2010; Dautartas, 2009; Janaway, 1996; Mant, 1987; Rodriguez \& Bass, 1985). Moisture can also become trapped within the soil, causing further breakdown of the remains because microbial activity thrives in these kinds of conditions (Aturaliya \& Lukasewyz, 1999; Burns, 2014; Dix \& Graham, 2000; Haglund \& Sorg, 2002; Mann et al. 1990). Specimens wrapped in garbage bags did not decompose as rapidly as those in t-shirts, or specimens on the soil surface. It is believed that this dramatic decrease in decomposition can be attributed to the subjects not being in direct contact with the environment (i.e., soil, insects, moisture, etc.) surrounding them, and a lack of oxygen to promote microbial activity.

Another factor that could explain the advanced rate of decay experienced by the clothed specimens, is the rather high number of maggots on the surface of, and throughout, the t-shirt. No maggots were observed on the actual remains, but the larvae's presence could also explain the high degree of decomposition. As the temperatures increased below the ground surface during the winter months, this provides a more hospitable environment for maggots and insects 
to thrive. On the ground surface, maggots and insects were not observed on the remains until late April (April 20 ${ }^{\text {th }}, 2018$ ). During this time, temperatures were consistently at or above $60^{\circ} \mathrm{F}$. When temperatures rose to $80^{\circ} \mathrm{F}$, the exposed maggots died. It is hypothesized that direct exposure to sunlight along with warm temperatures had an effect of the survival of this maggot.

As a result of this study, it has been observed that buried remains decompose differently from remains placed on the ground surface. Specimens on the soil surface became desiccated, with a hardened, leathery exterior. These specimens also experienced distinct changes in decomposition depending on the weather conditions. Decompositional changes to the ground specimens included becoming moist from snow/rainfall, then becoming desiccated again. This process was repeated several times throughout the course of this study. Those specimens buried, experienced a "wet" decomposition, becoming liquefied throughout the two and four-month intervals.

\section{A More Accurate Representation of the PMI}

From this analysis, a more accurate representation of the PMI can be created for areas similar to central Illinois, which experience cold air temperatures and snow/sleet/ice precipitation conditions for several months of the year. When subjects are placed on the ground surface in direct contact with soil, external temperatures and weather conditions directly influence the rate of decomposition. When temperatures dropped below $37^{\circ} \mathrm{F} / 2.8^{\circ} \mathrm{C}$, it caused the exposed surfaces of the subjects to become freezer burned and dehydrated eventually leading to desiccation. These cold temperatures also caused the musculature, fat, bone marrow, and skin to become bleached in color. Initially, these areas of the specimens were rather vibrant in color and intensity.

Following every rainfall over the course of these observation, the specimens became grey in color and were more odorous than at any other time. Days with direct sunlight also caused the 
ground surface specimens to become further desiccated, while also changing its color to a more darkened reddish-brown. After four months, this coloration changed to be almost completely black, which suggests a more mummified individual. Due to the amount of desiccation, the specimens also experienced a degree of shrinkage in circumference, as well as in height. While length was not recorded for each individual specimen, by the end of the four-month period, it was evident that the internal bone was protruding more from the examined specimen.

By late February, it was apparent that decompositional fluids were beginning to be emitted from the specimens. These fluids initially presented themselves as a red substance, believed to the blood, from the bone marrow. While this fluid was observed throughout the course of this study, it was not continuously seen on a daily basis. This fluid was only emitted on days where the temperature was above $37^{\circ} \mathrm{F} / 2.8^{\circ} \mathrm{C}$ (possibly due to defrosting of internal tissue). As this study progressed and temperatures continued to rise, more decompositional fluids began to seep from the surface specimens. In the latter half of April, from the $20^{\text {th }}$ onward, temperatures were almost exclusively above $60^{\circ} \mathrm{F} / 15.6^{\circ} \mathrm{C}$. Fluids were emitted from underneath the specimen, as well as from the fatty areas of the subject, and flowed into the soil or pooled on the actual specimen. An increase in temperature also caused the bone marrow to expand, creating a domed effect, although this eventually decreased after a following rainfall.

Creating a more accurate PMI estimation for subjects placed on the ground surface during colder months can be better assessed based on the data collected. When determining the PMI, it is important to record temperatures and weather conditions remains were subject to after death. Based on this study, remains that are initially subject to cold temperatures will decompose at a much slower rate and become desiccated over time. However, once temperatures begin to increase $\left(>37^{\circ} \mathrm{F} />2.8^{\circ} \mathrm{C}\right)$, the decomposition process will increase dramatically. An increase in 
decomposition will include the external surface remaining desiccated, while the internal structure begins to liquify. Increased temperatures $\left(>37^{\circ} \mathrm{F} />2.8^{\circ} \mathrm{C}\right)$ will also attract insects, further increasing the rate of decomposition.

Assessing the PMI for remains that are clothed and buried at various depths can also be better determined from these findings. Because the clothed specimens were not analyzed at any other time besides the two and four-month examinations, it is difficult to discern how quickly after placement the specimens began to decompose. After two months, clothed subjects that were buried had already begun to liquefy and lose their overall form. These specimens (A \& B) were difficult to handle due to their advanced state of decomposition, although it was noticed that the specimen (B) buried at 18 inches was much further decomposed than the specimen (B) at only 6 inches. After four months, the specimens (C \& D) were almost completely liquefied, with specimen D being in a much more advanced stage of decomposition. These specimens could only be handled for small intervals for fear of them completely separating from the t-shirt they were wrapped in. At this time, maggots were also observed on the t-shirts both specimens were wrapped in.

The presence of the maggots could be a determining factor in why the rate of decomposition was so dramatically accelerated compared to any other specimens. It is unknown how the maggots were able to travel to a depth of 18 inches, since the majority of fly species are unable to colonize remains buried more than $30 \mathrm{~cm}$ ( 12 inches) (Amendt et al., 2004; Amendt, Goff, Campobasso, \& Grassberger, 2010; Campobasso et al., 2001). The presence of these maggots could be due to the soil being disrupted from initial construction of the burial site, making it easier for the flies to access the remains due to looser soil. Another explanation is that the maggot species belongs to a group of flies known as Phoridae, commonly known as the 
coffin fly (Amendt et al., 2004; Benecke, 2001). This species is known to burrow up to half a meter a day (Benecke 2001), and have been found in coffins as low at 6 feet within the ground. The maggot species is unknown, as an entomological study was not conducted in conjunction with this analysis. The presence of these maggots at 18 inches could also be due to the actual placement of the specimens, since each subject was placed directly above and below one another. Initially, the maggots on specimen $\mathrm{C}$ (18 inches) could have been present on specimen $\mathrm{D}$ (6 inches), but instead travelled to the specimen buried at more deeply. Based off of both examinations, it was determined that the cotton t-shirt the specimens were wrapped in held the subjects together. This was an important factor, because otherwise the specimens would have completely decomposed into the soil, making it almost impossible to conduct an in-depth examination.

Remains found clothed and buried during or after a period of cold temperatures exhibit variations in their rates of decomposition based on how deeply they are interred. From this study, it has been concluded that remains buried deeper in the ground will reach an advanced stage of decomposition more quickly than those in a shallow grave. Remains buried just below the soil surface can still experience some weather conditions that exposed remains are subject to (i.e., moisture, frost, cold temperatures, etc.). Cold temperatures and ground frost can still affect shallow burial, whereas those buried further beneath the ground are not subject to some of these conditions, and temperatures are warmer (Brown \& DeGaetano, 2011; Coulson et al., 1995; Hu \& Feng, 2003; Minasny et al., 2016; Wendland, 1998). Ground temperatures were not taken over the course of this study, but it would be helpful in the future to take these readings to gain a better understanding of the temperature variations below the soil surface. 
When estimating the PMI for clothed buried remains, burial depth is an important factor. In warmer months, it has been observed that buried remains decompose at a slower rate than those on the ground surface due to protection from the elements and cooler temperatures (Burns, 2016; Campobasso et al., 2001; Carter et al., 2010; Dix \& Graham, 2000; Haglund \& Sorg, 2002; Mann et al., 1990; Pickering \& Bachman 2009; Rodriguez \& Bass, 1985). In winter months, protection from freezing and sub-freezing temperatures, is a factor that continues the decomposition process. If remains are found in a deeper grave, they will present themselves as being much more decomposed, suggesting a lengthier PMI, when in fact they could have been buried for a much shorter period of time.

Similar to the clothed specimens, subjects wrapped in plastic garbage bags and buried were only examined during the two and four-month intervals, making it difficult to discern when the decomposition process began. These specimens (E, F, G, and $\mathrm{H})$ were placed in plastic garbage bags and buried at depths of 6 and 18 inches. Surprisingly, these subjects maintained a fresher appearance for a longer period of time. Even during the four-month examination date the buried specimens maintained their overall shape and form, while appearing as though they were in the later stages of early decomposition. After two months, the specimens appeared relatively fresh with some breakdown of the musculature occurring to both specimens ( $\mathrm{E}$ and $\mathrm{F}$ ), and decompositional fluids forming within the garbage bag. The same was observed during the fourmonth examination, except at this time, the skin and fat had also begun to breakdown. Specimens buried at 18 inches also experienced a greater degree of decomposition compared to those specimens placed at only 6 inches.

While the amount of decomposition between the buried specimens at 6 and 18 inches was not drastic, like what was observed in the clothed remains, there were some identifiable 
differences. At two months, the musculature of the specimen at 18 inches was much more dulled or muted in color. The specimen at 6 inches, while beginning to dull in color, could still be characterized as having a pink/red coloration. There were also much more decomposition fluids that had accumulated within the garbage bag of the deeper buried specimen. At the four-month interval, the most noticeable difference was that the musculature of the bagged specimen at 6 inches was a much deeper brown, whereas the 18-inch specimen was very diluted in color and the skin had begun to break down and liquify.

It seems more difficult to determine the PMI when remains are placed into plastic garbage bags and buried. The visible differences between the specimens buried at 6 and 18 inches are likely due to temperature variations in soil depth. The fact that these specimens were also placed in an oxygen deficient environment (i.e., wrapped in a sealed plastic garbage bag) seems to have promoted a greater degree of preservation. No insects were found on any of the specimens placed in garbage bags or in the soil surrounding the specimens. During winter months, remains found in plastic garbage bags or wrapped in plastic coverings, lacking oxygen and direct contact with the environment, will appear better preserved and in the early stages of decomposition for a longer period of time.

Each of these subjects were placed in an environment (i.e., buried, clothed, covered in plastic, exposed) that could aid in the assessment of the PMI when remains are found in a variety of crime scene settings. Criminals often attempt to dispose of human remains so that investigators are unable to detect the body's location. To determine the PMI, it was determined that the most observed types of body disposal methods were tested. This included a specimen left exposed to the elements, uncovered, on the ground surface; burying remains at various depths (i.e., 6 and 18 inches); and covering the remains in either a cotton t-shirt or placed in a plastic 
garbage bag. The various depths at which the specimens were buried could suggest a rushed burial (at 6 inches) or a burial/premeditated murder where a perpetrator had time to dig a deeper grave. It should be mentioned that during the colder months of the year it is increasingly difficult to construct a grave at even 18 inches. If a perpetrator were to dig a grave during the colder months, it would take a fair amount of time and energy before it was completed, creating a greater probability of being caught. Specimens were also clothed to signify a human body that still had clothing on at the time of burial. Garbage bags or plastic coverings have also been used by criminals to conceal a body, making the detection of the remains more difficult.

\section{Insect Observation}

Maggots were not identified at the species level; however, two different sizes were observed. Maggots were not observed on the ground surface specimen (specimen I) until late April. During this time, temperatures had risen to around or above $60^{\circ} \mathrm{F}$. Typically, temperatures below $50^{\circ} \mathrm{F}$ inhibits the amount of insect activity, which is likely why no insects were present until late April (Burns, 2016; Campobasso et al., 2011; Catts \& Goff, 1992; Haskell et al., 1997; Introna et al., 1991; Rodriguez \& Bass, 1983). Maggots and other insects were not observed in January, February, or March, although the ground surface specimens were not continuously monitored so it is unknown whether insects were present during these months and went unnoticed.

In late March ( March $\left.28^{\text {th }}, 2018\right)$, small openings began to form in the superior portion of specimen I; in a large fatty area within the musculature. Initially, these openings could not be entered by flies, although it was noticed in April that they were attempting to gain access to the internal portion of the subject. These openings could be analogous to orifices (i.e., nostrils, mouth, ears, genitals, eyes) in human cadavers, as cavitation's may offer shelter for maggot 
proliferation (Byers, 2017; Miller, 2002; Pickering \& Bachman, 2009; Haglund \& Sorg, 2002). Since the external surface of the specimen had become desiccated, this could have created another deterrent for flies to lay their eggs. Maggots feed on the soft tissues of remains, and if these tissues are difficult to reach, there is less likelihood for their survival (Campobasso et al., 2001; Haglund \& Sorg, 2002; Introna et al., 1991).

On April $24^{\text {th }}$, there was the first siting of maggots along the opening created on the external surface of the specimen. These maggots were very small ( $<1 / 4$ inch), and seemed to be traveling toward the internal surface of the remains. On this day, the high temperature was $67^{\circ} \mathrm{F}$, and there was some cloud cover, protecting the maggots from direct sunlight. Flies had previously been observed on and around the surface specimen on April $20^{\text {th }}$, but not maggots were observed. These maggots continued to be observed until April $26^{\text {th }}$, although their numbers were far fewer than what was observed on the $24^{\text {th }}$. By April $27^{\text {th }}$, maggots could no longer be observed on the external surface or through the openings created in the remains. Maggots could have been inside the specimen feeding on the soft tissues, causing further destruction to the subject. On April 29 ${ }^{\text {th }}$, it is believed that springtails were observed on the external surface of the remains. Springtails are a small arthropod that inhabit the soil, decaying materials, and plants (Helbig, Nickerl, Neinhuis, \& Werner, 2011; Hopkin, 1997). These small insects tend to feed on plant materials, but have also been known to feed upon human cadavers (Folsom, 1902).

By May $1^{\text {st }}$, large maggot had appeared from the opening along the external surface. This maggot was much larger than what was previously observed (>1/4 inch). While this maggot was alive and appeared to be feeding on the first of the month, by May $2^{\text {nd }}$, the maggot appeared to be deceased. There was no longer any movement from the maggot and it remained stationary through the remainder of the study. Its death could be due to a high ambient temperature $\left(\sim 80^{\circ} \mathrm{F}\right)$ 
and direct sunlight (Benecke, 2001; Campobasso et al., 2001; Haglund \& Sorg, 2002; Rodriguez $\&$ Bass, 1983). It was not until May $7^{\text {th }}$ when large (>1/4 inch) maggots were observed again, this time as a maggot mass along the underside of specimen I. In this area, it was moist due to the decompositional fluids seeping into the soil surface, and there was some protection from direct sunlight. It is unknown how many maggots were present at this time. The maggot mass decreased in size by May $8^{\text {th }}$, at which time the mass has disseminated and only a few maggots remained in this area. From May $9^{\text {th }}$ until May $11^{\text {th }}$ (examination date), no maggots were present on the surface of the specimen or in the area directly around it. There is the possibility that the maggots had retreated inside the subject, but the specimen was not internally examined due to the amount of desiccation. On the examination date, there were flies present throughout the entire examination, this included large ( 1/2 inch) and small ( 1/4 inch) flies. The exact species of flies visiting the subject is unknown.

Maggots were also observed on May $11^{\text {th }}$ for those specimens wrapped in white cotton tshirts and buried. At 6 inches below the soil surface, there were far fewer maggots on the cotton t-shirt than what was observed at 18 inches. Maggots were not observed on the outside of the tshirt, and it did not appear as though there were any maggots throughout the layers of the t-shirt. Upon closer inspection, a small number of maggots were present as the t-shirt was being unwrapped. These maggots were closer to the remains wrapped within the clothing, but no maggots were observed directly on the specimen. At 18 inches, there was a greater number of maggots present on the external surface of the t-shirt, as well as throughout all layers of the shirt. No maggots were present directly on the actual specimen at the time of examination. As previously stated, it is unknowns exactly why maggots were observed so deep within the ground. Normally, flies are unable to populate remains buried deeper than around 12 inches beneath the 
soil surface. Due to the ground being disrupted from site construction, the loose soil could have made it easier for flies to penetrate the ground surface in order to colonize the buried remains. Another explanation could be that the maggots belong to the fly species Phoridae (coffin fly). These species have been known to burrow at least 6 feet beneath the ground surface, laying their eggs and feeding upon decomposing remains (Amendt et al., 2004; Campobasso et al., 2001; Campobasso, Henry, Disney, \& Introna, 2004; Martin-Vega, Gomez-Gomez, \& Baz, 2011). Still another explanation for the high prevalence of maggots at 18 inches, could be due to the placement of the specimens beneath the ground. Each specimen was placed directly above and below one another, so any maggots that may have been present on the specimen at 6 inches (specimen D) could have travelled to specimen $\mathrm{C}$ at 18 inches to escape higher temperatures. In the future, it would be useful to conduct an entomological study on the kinds of insect frequenting the remains in order to better understand what how and when they begin to affect the decomposition process.

At both the two and four-month interval, no maggots were observed on the buried remains wrapped in plastic garbage bags. The lack of insect activity is believed to be one of the reasons for a lack of advanced decompositions (Mann et al., 1990). The sealed garbage bag would have made it difficult for insect to identify the location of the remains, since an odor would not be as easily detected. This kind of covering also creates an oxygen deficient environment, which would have created an inhospitable environment for mature flies to lay their eggs, and for maggots to survive.

\section{Soil Analysis Interpretation}

The soil analysis provided by A\&L Greatlakes Laboratories provides information on the soil composition and properties found at this studies test site. These properties include measures 
of organic matter, phosphorus, potassium, magnesium, calcium, $\mathrm{CEC}$ and soil $\mathrm{pH}$. At the start of this study, soil was collected at depths of 6 inches and 18 inches (i.e., where the specimens would be placed in the ground). Samples were taken in order to determine if the soil had an effect on the rate of decomposition. When the soil samples were taken, it was observed that the sample at 6 inches contained more clay than the sample at 18 inches, which consisted of both clay and black soil. There were distinct visual differenced in the soil layers, with the topmost portion consisting of black soil, followed by clay. After the first layer of clay, there was a small ( 2 inches) layer of black soil, followed by a combination of clay and black soil until the trench stopped at 18 inches. A soil sample was not taken from the ground surface, so it is uncertain how the surface soil would affect the specimens placed in this area.

The measure or organic matter was recorded at $2.9 \%$ for both 6 and 18 -inch soil samples. This was just below the optimum range of 3-5\%. Organic matter is composed of plant and animal materials that have begun to break down along with insects and microorganisms. Factors affecting the amount of organic matter include soil texture and drainage (Hazelton \& Murphy, 2016; Horneck, Sullivan, Owen, \& Hart, 2011; Spargo, Allen, \& Kariuki, 2013; Wroth, 1984). Well-drained, course textured soils tend to contain lower levels of organic materials due to rapid microbial decomposition rates. The amount of moisture held in the soil is also directly linked to the amount of organic matter in the soil (Hazelton \& Murphy, 2016; Jones, 1993; Spargo et al., 2013).

Phosphorus, potassium, magnesium, and calcium are all essential nutrients for the promotion of plant life. The amount of phosphorus from the 6-inch soil sample was recorded at 28ppm, while the 18 -inch samples was recorded at $5 \mathrm{ppm}$. A reading of $28 \mathrm{ppm}$ is at the optimum rate, whereas a reading of $5 \mathrm{ppm}$ is considered very low. A low reading of phosphorus in soils 
can lead to impaired vegetative growth, weakened root systems, and poor plant quality (Hazelton \& Murphy, 2016; Horneck et al., 2011; Jones, 1993; Spargo et al., 2013). The amount of potassium was recorded at 136ppm for the 6-inch soil sample, and 112ppm for the 18-inch sample. Both of these readings are in the optimal range. When potassium is deficient in soils, plants are unable to utilize either nitrogen or water efficiently, leading to disease (Horneck et al., 2011). The readings for the amount of magnesium in both soil samples what high, with the 6inch sample having a reading of $485 \mathrm{ppm}$, and the 18 -inch samples having a reading of $705 \mathrm{ppm}$. It is unknown exactly why this reading was so high, since excess magnesium typically occurs in serpentine soils (Horneck et al., 2011; Jones, 1993). The reading for calcium was recorded at 3150ppm for the 6-inch sample, and 2550ppm for the 18-inch sample. While the soil sample at 18-inches came back between the optimum range for calcium, the measure at the 6-inch sample was considered high. Calcium is needed so that plant cell walls and membranes can properly function. Over 1.5 to 2 years of decomposition can cause the calcium and magnesium levels in the soil to rise, indicating bone seepage even if there is little change in the appearance of the bone (Vass et al., 1992).

The CEC for the 6-inch samples was measured at 20.1, and the 18-inch sample was measured at 18.9. CEC is recorded in units of milli-equivalents per 100 grams of soil (meq/100g). CEC can range from below $5 \mathrm{meq} / 100 \mathrm{~g}$ in sandy soils with low organic matter to values above $15 \mathrm{meq} / 100 \mathrm{~g}$ belong to finer textures soils with high organic matter (Horneck et al., 2011; Jones, 1993; Spargo et al., 2013). Both of the soil samples in the study were well above $15 \mathrm{meq} / 100 \mathrm{~g}$, suggesting they were highly buffered. Higher CEC soils tend to hold more nutrients, but they may not necessarily be more productive than other soils low in CEC. 
Soil $\mathrm{pH}$ was relatively similar for both soil samples, with the 6-inch sample having a $\mathrm{pH}$ of 7.6, and the 18-inch sample having a $\mathrm{pH}$ of 7.3. A pH of 7.0 is considered neutral, with readings below this being more acidic, and readings above 7.0 being more alkaline. In general, plants grow best when the soil $\mathrm{pH}$ ranges between 6.0 to 7.0 . When the $\mathrm{pH}$ is greater, as in the case of this study, phosphorus and other trace minerals may be less available (Horneck et al., 2011). A pH in the optimum range (6.0-7.0) minimizes the solubility of toxic elements and is beneficial to soil organisms (Haslam \& Tibbett, 2009; Hopkins et al., 2000; Horneck et al., 2011; Rodriguez \& Bass, 1985; Vass et al., 1992; Wilson et al., 2007). The soil pH reading from this study suggests that both samples were slightly alkaline, since both readings were above a $\mathrm{pH}$ of 7.0. As concluded by Haslam and Tibbett (2009), and Rodriguez and Bass (1985), soils in contact with skeletal muscular tissue (SMT) became more alkaline as the decomposition process progressed, eventually returning to their starting values by the completion of the incubation period. However, soils in this study were collected before the placement of the subjects within the ground, so it is uncertain if the recorded readings would have increased in alkalinity over time. Soil samples were not collected at the two or four-month intervals, and it is undetermined how the $\mathrm{pH}$ changed over time. In the future, it would be beneficial to take these readings in order to determine if there is a dramatic change in $\mathrm{pH}$ values over the course of the decomposition process in winter months. 


\section{CHAPTER VI: CONCLUSION}

Ten partial pig (Sus scrofa) specimens were placed in specific test settings in order to determine if a better estimation of the PMI can be created when cold temperatures and weather conditions are recorded. The test settings included burial depth (ground surface and at 6 and 18 inches below ground), clothed in a white cotton t-shirt, placed and wrapped in a plastic garbage bag, and left exposed on the ground surface. Each of these specialized environments and coverings allowed for conclusions to be made regarding how remains decompose in these settings from January to May 2018. During these months, cold weather conditions (i.e., snow, frost, ice, etc.) were observed on several occasions, accompanied by cold temperatures $\left(<37^{\circ} \mathrm{F} / 2 \cdot 8^{\circ} \mathrm{C}\right)$.

Based off this experiment, these conditions reduced the rate of decomposition (based on forensic norms) (Burns, 2016; Carter, Yellowlees, \& Tibbett, 2010; Dix \& Graham, 2000; Haglund \& Sorg, 2002; Mann et al., 1990; Pickering \& Bachman, 2009; Rodriguez \& Bass, 1985) in the specimens placed on the ground surface, as well as those placed in a shallow burial (6 inches). At 18 inches, specimens are less likely to come in contact with extreme weather conditions (Brown \& DeGaetano, 2011; Coulson et al., 1995; Minasny et al., 2016; Wendland, 1998) and result in continuing decomposition. The decomposition process of the partial pig (Sus scrofa) remains in this study were compared to previous studies which had been conducted on remains (i.e., animal and human) subject to freezing and thawing conditions (Bunch, 2009; Komar, 1998; Micozzi, 1986; Roberts \& Dabbs, 2015; Zugibe \& Costello, 1993). These studies concluded that remains subject to freezing and thawing decomposed from the "inside-out." 
This study provides some baseline information for estimating the PMI in cold weather settings. It also revealed what other factors need to be controlled for future refinements of PMI estimation. Ultimately, cold temperature is the factor that appears to disrupt the decomposition process most, dramatically slowing the rate at which decomposition occurs. When temperatures were at or below $37^{\circ} \mathrm{F} / 2.8^{\circ} \mathrm{C}$, the amount of decomposition observed on the surface specimens was minimal, with the external surface becoming desiccated. Once temperatures increased to $40^{\circ} \mathrm{F} / 4.4^{\circ} \mathrm{C}$ and above, the amount of decomposition was accelerated. Higher (warmer) temperatures $\left(>60^{\circ} \mathrm{F} / 15.6^{\circ} \mathrm{C}\right)$ were recorded near the end of this study, during which time, the surface specimen began to emit decompositional fluids and attract insects, furthering the amount of breakdown.

Those specimens buried at 6 inches were subject to lower temperatures, hypothesized to be consistent with the recorded daily air temperature reading, which could be why those buried at this depth were better preserved than the specimens at 18 inches. At 18 inches, the clothed and covered specimens decomposed at a much more accelerated rate. It is believed that in the winter month, temperatures increase as burial depth increases, sheltering remains from the harsh conditions on the surface.

In assessing the PMI when cold temperatures and variable weather conditions are present, it is necessary to understand that the kind of setting a subject is placed in (i.e., buried, clothed, covered, exposed) can alter the rate of decomposition. Over the course of four months, specimens on the ground surface became desiccated with their internal surface becoming liquefied. Clothed specimens that were buried liquefied, whereas those in plastic garbage bags were somewhat minimally decomposed with both specimens at four months being in the earlier stages of advanced decomposition. While there is more research and analysis to be conducted on 
the effects that cold weather settings have on remains, this study provides a baseline into how to assess the PMI.

Continued experimentation needs to be undertaken in order to understand the effects that cold weather conditions have on the decompositions process. Ultimately, the use of human cadavers or complete pig carcasses (weighing at least 50.7 pounds with internal viscera) (Campobasso et al., 2001; Goff, 1993; Notter, Stuart, Rowe, \& Langlois, 2009; Roberts \& Dabbs 2015; Schoenly, Haskell, Mills, Bieme-Ndi, \& Yer Lee, 2006) would provide the most insight into the decomposition process in cold weather settings. The current experiment could not, for example address decomposition of internal viscera. However, in the interim, future studies should:

- Use instruments to record soil temperatures, as well as the temperatures of the actual specimens in order to determine how they change across decomposition stages or as the ambient temperature varies.

- It would also be beneficial to conduct an entomological study in accompaniment with the decomposition study to learn which insect species are present on the remains at given temperatures.

- Change in soil pH should be tested. Soil samples should be taken at the time of deposition and exhumation, as well as $\mathrm{pH}$ congruent with weather (particularly precipitation) changes.

- Samples should be as close to identical as possible in size, weight skin coverage, and ideally, body element segment, in order to provide controls for the effects of cold, moisture, covering, and soil depth on decomposition. 
- More recovery intervals should be undertaken in order to better control for weather variability. 


\section{REFERENCES}

Amendt, J., Krettek, R., \& Zehner, R. (2004). Forensic entomology. Naturwissenschaften, 91, 51-65.

Amendt, J., Goff, M. L., Campobasso, C. P., \& Grassberger, M. (2010). Current concepts in forensic entomology (Vol. 376). Springer Science \& Business Media BV.

Aturaliya S., Lukasewycz A. (1999). Experimental forensic and bioanthropological aspects of soft tissue taphonomy: 1. factors influencing postmortem tissue desiccation rate. Journal of Forensic Sciences, 44(5), 893-896.

Beever, C. E. (2014). Strengthening clothing damage analysis: Quantification of stabbing force and weathering (Doctoral Dissertation), University of Huddersfield.

Benecke, M. (2001). A brief history of forensic entomology. Forensic Science International, $120,2-14$.

Blakemore, Colin., \& Jennett, Sheila. (2001). The Oxford companion to the body. Oxford: Oxford University Press

Bostock, E., Parkes, G., \& Williams, G. (2018). Effect of decomposition on clothing damage evidence: A preliminary study. Crime Security and Society, 1(2)

Brock, T. D., \& Madigan, M. T. (1988). Biology of microorganisms. Englewood Cliffs, NJ: Prentice-Hall.

Brown, P. J., \& DeGaetano, A. T. (2011). A paradox of cooling winter soil surface temperatures in a warming northeastern United States. Agricultural and Forest Meteorology, 151(7), 947-956.

Bunch, A. W. (2009). The impact of cold climate on the decomposition process. Journal of Forensic Identification, 59(1), 26-44.

Burns, K. R. (2016). Forensic anthropology training manual. New York: Taylor \& Francis.

Byers, S. N. (2017). Introduction of forensic anthropology. New York: Taylor \& Francis. 
Cahoon S.E., (1992). Effects of clothing on human decomposition and deterioration of associated yarns (Master's Thesis). University of Tennessee, Knoxville.

Campobasso, C. P., DiVella, G, \& Introna, F. (2001). Factors affecting decomposition and Diptera colonization. Forensic Science International, 120, 18-27.

Campobasso, C. P., Henry, R., Disney, L., \& Introna, F. (2004). A case of Megaselia scalaris (Loew) (Dipt., Phoridae) breeding in a human corpse. Anil Aggrawal's Internet Journal of Forensic Medicine and Toxicology, 5(1), 3-5.

Carter, D. O., Yellowlees, D., \& M. Tibbett. (2010). Moisture can be the dominant environmental parameter governing cadaver decomposition in soil. Forensic Science International, 200(1-3), 60-66.

Catts, E. P., \& Goff, M. L. (1992). Forensic entomology in criminal investigations. Annual Review of Entomology, 37, 253-272.

Cheng, L., Angle, R. P., \& Sandhu, H. S. (1997). Seasonal variations of volatile organic compounds in Edmonton, Alberta. Atmospheric Environment, 31(2), 239-246.

Clark, M. A., Worrell, M. B., \& Pless, J. E. (1997). Postmortem changes in soft tissues. In W. D. Haglund \& M. H. Sorg (Eds.), Forensic taphonomy: postmortem fate of human remains. New York: CRC Press.

Coulson, S. J., Hodkinson, I. D., Strathdee, A. T., Block, W., Webb, N. R., Bale, S. J., \& Worland, M. R. (1995). Thermal environments of Arctic soil organisms during winter. Arctic and Alpine Research, 27(4), 364-370.

Cunningham, F. E., \& Bowers, J. A. (1977). Composition, microbial content, and stability of chicken patties held at refrigerator temperature. Poultry Science, 56(1), 93-97.

Damann, F. E., Williams, D. E., \& Layton, A. C., (2015). Potential use of bacterial community succession in decaying human bone for estimating postmortem interval. Journal of Forensic Sciences, 60(4), 844-850.

Dautartas, A. M. (2009). The effect of various coverings on the rate of human decomposition (Master's Thesis). University of Tennessee, Knoxville.

Dix, J., \& Graham M. (2000). Time of death, decomposition, and identification: An atlas. New York: CRC Press. 
Erzinclioglu, Y. Z. (1990). Forensic entomology and criminal investigation. The Police Journal, 64(1), 5-8.

Finley, S. J., Pechal, J. L., Benbow, M. E., Robertson, B. K., \& Javan, G. T. (2016). Microbial signatures of cadaver gravesoil during decomposition. Microbial Ecology, 71(3), 524529.

Folsom, J. W. (1902). Collembola of the grave. Psyche, 9(315), 363-367.

Forbes, S. I. (2008). Decomposition chemistry in burial environment. In M. Tibbett \& D. O. Carter (Eds.), Soil analysis in forensic taphonomy. New York: CRC Press.

Galloway, A., Birkby, W., Jones, A. M., Henry, T. E., \& Parks, B. O. (1989). Decay rates of human remains in an arid environment. Journal of Forensic Sciences, 34(3), 607-616.

Geisenberger, D., Wuest, F., Bielefeld, L., Perdekamp, M. G., Pircher, R., Pollak, S., ThieraufEmberger, A., \& Huppert, L. M. (2014). Fat from contused adipose tissue may cause yellow discoloration of clothes in blunt trauma victims. Forensic Science International, $245,72-76$.

Gill-King, H. (1997). Chemical and ultrastructural aspects of decomposition. In W. D. Haglund \& M. H. Sorg (Eds.), Forensic taphonomy: Postmortem fate of human remains. New York: CRC Press.

Goff, M. L. (1993). Estimation of the postmortem interval using arthropod development and successional patterns. Forensic Science Review, 5, 81-94

Gonzales, T. A., Vance, M., Helpern, M., \& Umberger, C. J. (1954). Legal medicine, pathology and toxicology. New York: Appleton-Century-Crofts Inc.

Hage, K. D. (1972). Nocturnal temperatures in Edmonton, Alberta. Journal of Applied Meteorology, 11(1), 123-129.

Haglund, W., Reay, D. T., \& Swindler D. R. (1989). Canid scavenging/disarticulation sequence of human remains in the Pacific Northwest. Journal of Forensic Sciences, 34(3), 587606. 
Haglund, W., \& Sorg, M. H. (Eds.). (1997). Forensic taphonomy: Postmortem fate of human remains. New York: CRC Press.

Haglund W., \& Sorg M. H. (Eds.). (2002). Advances in forensic taphonomy: Method, theory, and archaeological perspectives. New York: CRC Press.

Haskell, N. H., Hall, R. D., Cervenka, V. J., \& Clark, M. A. (1997). On the body: Insects' life stage presence and their postmortem artifacts. In W. D. Haglund \& M. H. Sorg (Eds.), Forensic taphonomy: Postmortem fate of human remains. New York: CRC Press.

Haslam, T. C., \& Tibbett, M. (2009). Soils of contrasting pH affect the decomposition of buried mammalian (Ovis aries) skeletal muscular tissue. Journal of Forensic Sciences, 54(4), 900-904.

Hayman, J., \& Oxenham, M. (2016). Human body decomposition. London, England: Academic Press.

Hazelton, P., \& Murphy, B. (2016). Interpreting soil test results: What do all the numbers mean?. Australia: CSIRO publishing.

Helbig, R., Nickerl, J., Neinhuis, C., Werner, C. (2011). Smart skin patterns protect springtails. PLoS ONE, 6(9), e25105. https://doi.org/10.137/journal.pone.0025105

Hopkins, D. W., Wiltshire, P. E. J., \& Turner, B. D. (2000). Microbial characteristics of soils from graves: an investigation at the interface of soil microbiology and forensic science. Applied Soil Ecology, 14(3), 283-288.

Horneck, D. A., Sullivan, D. M., Owen, J. S., \& Hart, J. M., Soil test interpretation guide [PDF file]. Retrieved from https://ir.library.oregonstate.edu/concern/administrative_report_or_publications/2b88qc4 $5 x$.

Hu, Q., \& Feng, S. (2003). A daily soil temperature dataset and soil temperature climatology of the contiguous United States. Journal of Applied Meteorology, 42(8), 1139-1156.

Hyde, E. R., Haarmann, D. P., Lynne, A. M., Bucheli, S. R., \& Petrosino, J. F. (2015). Initial insights into bacterial succession during human decomposition. International Journal of Legal Medicine, 129(3), 661-671. 
Introna, F., Suman T., \& Smialek, J. (1991). Sarcosaprophagous fly activity in Maryland. Journal of Forensic Sciences, 36(1), 238-243.

Iscan, M. Y., \& Steyn M. (2013). The human skeleton in forensic medicine. Sprngfield, IL: Charles C. Thomas Publisher.

Janaway, R. C. (1996). The decay of buried human remains and their associated materials. In J. Hunter, C. Roberts, \& A. Martin (Eds.), Studies in crime: An introduction to forensic archaeology. London: Batsford.

Janaway, R. C., Steve., L. P., \& Wilson, A. S. (2009). Decomposition of human remains. Microbiology and Aging, 313-334. Humana Press.

Jones, J. B. (2001). Laboratory guide for conducting soil tests and plant analysis. Boca Raton: CRC Press.

Keh, B. (1985). Scope and applications of forensic entomology. Annual Review of Entomology, $30,137-154$.

Kelly, J. A., Van der Linde, T.C., \& Anderson, G. S. (2009). The influence of clothing and wrapping on carcass decomposition and arthropod succession during the warmer seasons in Central South Africa. Journal of Forensic Sciences, 54(5), 1105-1112.

Komar, D. A. (1998). Decay rates in a cold climate region: A review of cases involving advanced decomposition from the medical examiner's office in Edmonton, Alberta. Journal of Forensic Sciences, 43(1), 57-61.

Krahmer, L. (1857). Handbuch der gerichtilichen Medizin. Schwerschke.

Love, J. C., \& Marks, M. K. (2003). Taphonomy and time: estimating the postmortem interval. In D. W. Steadman (Ed.), Hard evidence: Case studies in forensic anthropology. Upper Saddle River, NJ: Pearson Education.

Lowe, A. C., Beresford, D. V., Carter, D. O., Gaspari, F., O’Brien, R. C., Stuart, B. H., \& Forbes, S. L. (2013). The effect of soil texture on the degradation of textiles association with buried bodies. Forensic Science International, 23(1-3), 331-339.

Manhein, M. H. (1997). Decomposition rates of deliberate burials: A case study of preservation. In W. D. Haglund \& M. Sorg (Eds.), Forensic taphonomy: The postmortem fate of human remains. New York: CRC Press. 
Mann, R. W., Bass, W. M., \& Meadows, L. (1990). Time since death and decomposition of the human body: variables and observations in case and experimental field studies. Journal of Forensic Sciences, 35, 103-111.

Mant, A. K. (1987). Knowledge acquired from post-war exhumations. In A. Boddington, A. N. Garland, \& R. C. Janaway (Eds.), Death, decay and reconstruction: Approaches to archaeology and forensic sciences. Manchester, England: Manchester University Press.

Martin-Vega, D., Gomez-Gomez, A., \& Baz, A. (2011). The "coffin fly" Conicera tibialis (Diptera: Phoridae) breeding on buried human remains after a postmortem interval of 18 years. Journal of Forensic Sciences, 56(6), 1654-1656.

Matuszewski, S., Konweski, S., Fratczak, K., \& Szafalowicz M., (2014). Effects of body mass and clothing on decomposition of pig carcasses. International Journal of Legal Medicine, $128(6), 1039-1048$.

Megyesi, M.S., Nawrocki, S. P., \& Haskell, N. H. (2005). Using accumulated degree days to estimate the postmortem interval from decomposed human remains. Journal of Forensic Sciences, 50, 1-9.

Micozzi, M. S. (1986). Experimental study of postmortem change under field conditions: Effects of freezing, thawing, and mechanical injury. Journal of Forensic Sciences, 31(3), 953961.

Miller, R. A. (2002). The affects of clothing on human decomposition: Implications for estimating time since death (Master's Thesis). University of Tennessee, Knoxville.

Minsany, B., Stockmann, U., Hartemink, A. E., \& McBratney, A. B. (2016). Measuring and modelling soil depth functions. In A. E. Hartemink \& B. Minsany (Eds.), Digital soil morphometrics, progress in soil science. Switzerland: Springer International Publishing.

Notter, S.J., Stuart, B. H., Rowe, R., \& Langlois, N. (2009). The initial changes of fat deposits during the decomposition of human and pig remains. Journal of Forensic Sciences, 54(1), 195-201.

Pickering, R. B., \& Bachman, D. (2009). The use of forensic anthropology. Boca Raton, FL: Taylor \& Francis.

Pokines, J., \& Symes, S. A. (2013). Manual offorensic taphonomy. Boca Raton, FL: CRC Press. 
Powers, R. H. (2005). The decomposition of human remains. Forensic Medicine of the Lower Extremity, 3-15.

Roberts, L. G., \& Dabbs, G. R. (2015). A taphonomic study exploring the differences in decomposition rate and manner between frozen and never frozen domestic pigs (Sus scrofa). Journal of Forensic Sciences, 60(3), 588-594.

Rodriguez, W., \& Bass, W. M. (1983). Insect activity and its relationship to decay rates of human cadavers in East Tennessee. Journal of Forensic Sciences, 28(2), 423-432.

Rodriguez, W., \& Bass, W. M. (1985). Decomposition of buried bodies and methods that may aid in their location. Journal of Forensic Sciences, 30(3), 836-852.

Santa, Janin. (2017). The effect of temperature on bacterial growth. Retrieved from https://healthyliving.azcentral.com/the-effect-of-temperature-on-bacterial-growth12215331.html

Schoenly, K. G., Haskell, N. H., Mills, D. K., Bieme-Ndi, C., \& Yer Lee, K. L., (2006). Recreating death's acre in the school yard: Using pig carcasses as model corpses. American Biology Teacher, 68(7), 402-410.

Simmons, T., Cross, P. A., Adlam, R. E., \& Moffatt, Colin. (2010). The influence of insects on decomposition rate in buried and surface remains. Journal of Forensic Sciences, 55(4), 889-892.

Spargo, J., Allen, T., \& Kariuki, S. (2013). Interpreting your soil test results [PDF file]. Retrieved from http://ag.umass.edu/soil-plant-nutrient-testing-laboratory/factsheets/interpreting-your-soil-test-results

Stuart, B. H., \& Ueland, M. (2017). Degradation of clothing in decompositional environments. In E. M. J. Schotsmans, N. Marquez-Grant, \& S. L. Forbes (Eds.) Taphonomy of Human Remains: Forensic Analysis of the Dead and the Depositional Environment. John Wiley \& Sons Ltd.

Vass, A. A., Bass, W. M., Wolt, J. D., Foss, J. E., \& Ammons, J. T. (1992). Time since death determination of human cadavers using soil solution. Journal of Forensic Sciences, 57, 1236-1253. 
Vass, A. A. (2001). Beyond the grave-understanding human decomposition. Microbial Today, 28, 190-193.

Vass, A. A., Barshik, S. A., Sega, G., Caton, J., Skeen, J. T., Love, J. C., \& Synstelien, J. A. (2002). Decomposition chemistry of human remains: A new methodology for determining the postmortem interval. Journal of Forensic Sciences, 47(3), 542-553.

Wang, X. L. (2005). Climatology and trends in some adverse and fair weather conditions in Canada, 1953-2004. Journal of Geophysical Research, 111, 1-27.

Wendland, W. (1998). A ground frost climatology for Illinois. Transactions of the Illinois State Academy of Science, 91(1), 57-67.

Wilson, A. S., Janaway, R. C., Holland, A. D., Dodson, H. I., Baran, E., Pollard, A. M., \& Tobin, D. J. (2007). Modelling the buried human body environment in upland climes using three contrasting field sites. Forensic Science International, 169(1), 6-18.

Wroth, C. P. (1984). The interpretation of in situ soil tests. Geotechnique, 34(4), 449-489.

Zhao, H., Shu, C., Fan, X., Cao, J., \& Jiang, W. (2018). Near-freezing temperature storage prolongs storage period and improves antioxidant capacity of nectarines. Scientia Horticulturae, 228, 196-203.

Zhou, C., \& Byard, R. W. (2011). Factors and processes causing accelerated decomposition in human cadavers- An overview. Journal of Forensic and Legal Medicine, 18(1), 6-9.

Zugibe, F. T., \& Costello, J. T. (1993). The iceman murder: One of a series of contract murders. Journal of Forensic Sciences, 38(6), 1404-1408. 
APPENDIX A: PARTIAL PIG (SUS SCROFA) PHOTOGRAPHS 
a.

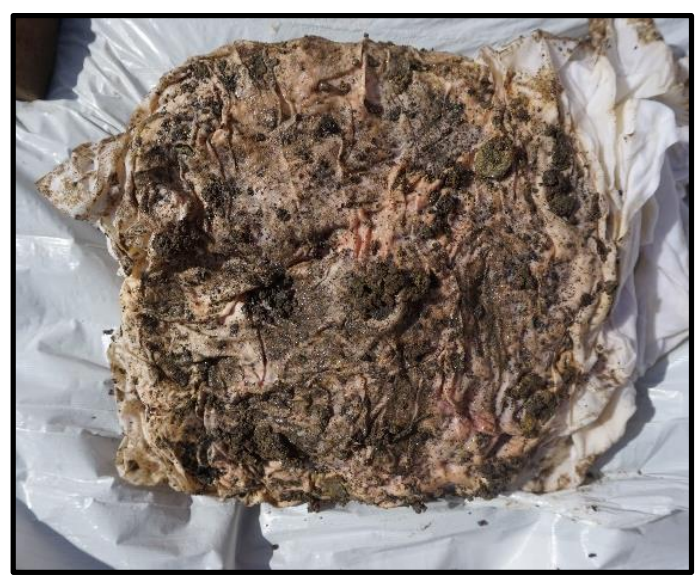

1

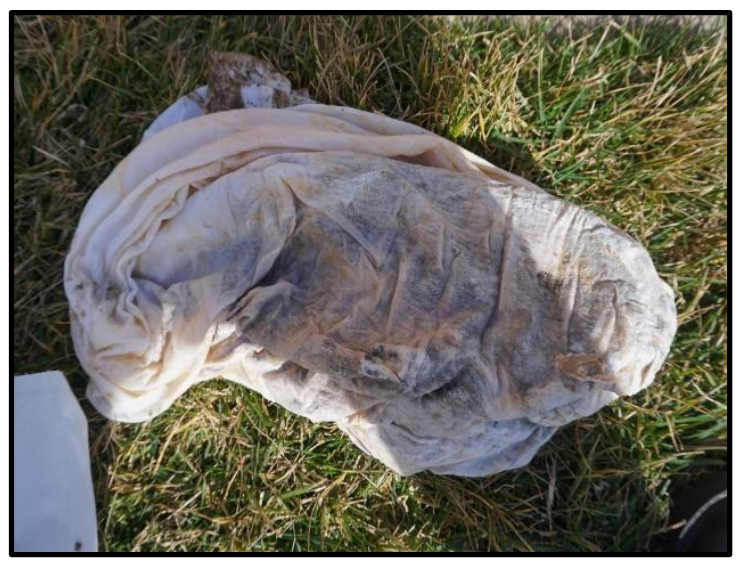

2 b.

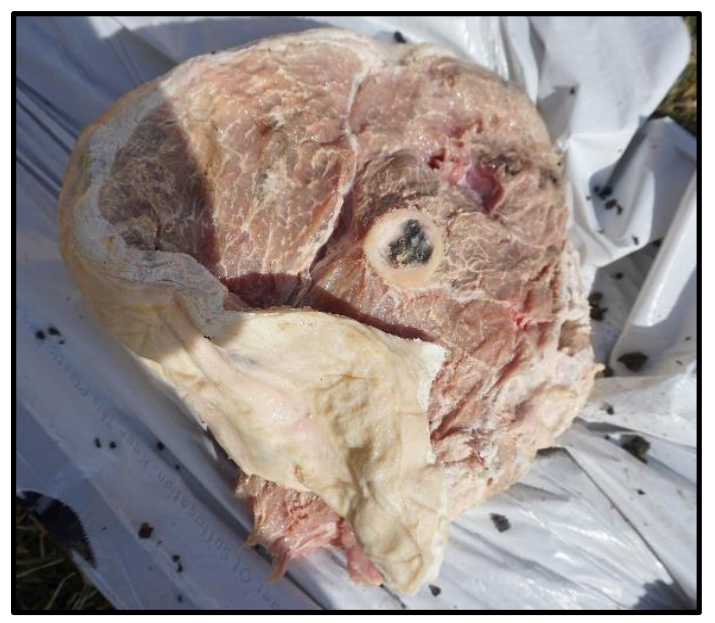

1

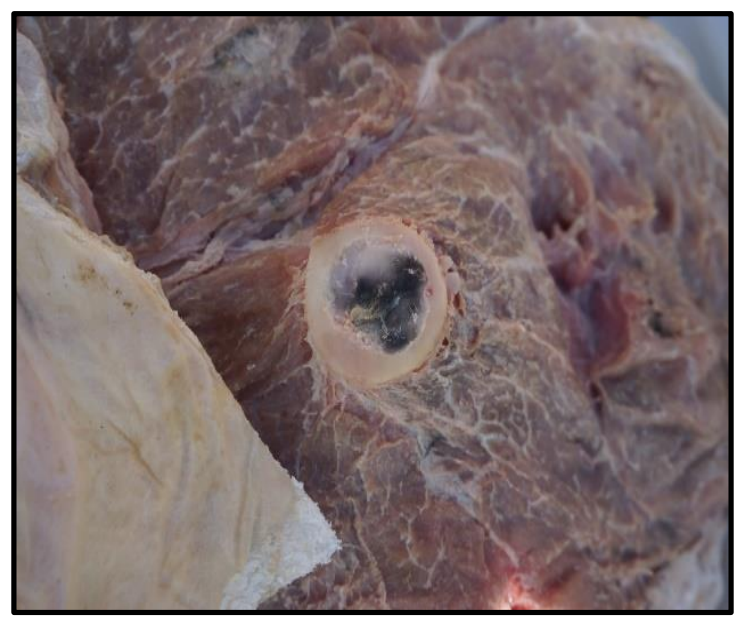

2

Figure 1. Specimen A during the two-month examination: a1. T-shirt clinging tightly to specimen A; a2. Yellow discoloration of the t-shirt.

b1. Full extent of specimen A; b2. Bone marrow turning black in color. 
a.

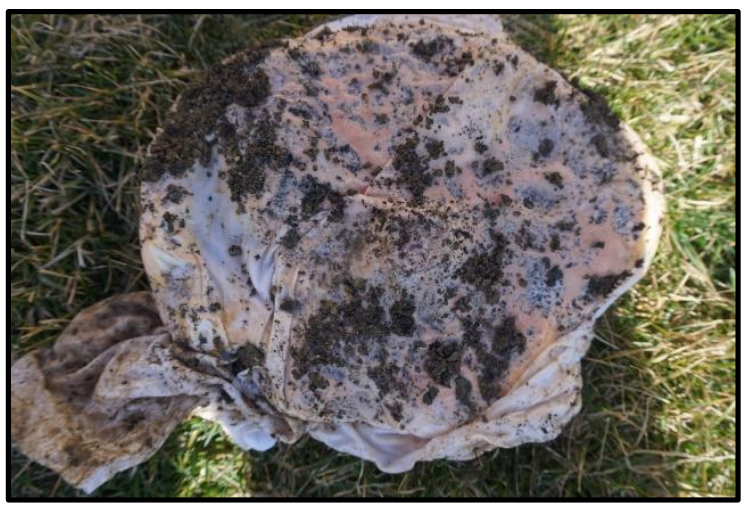

1

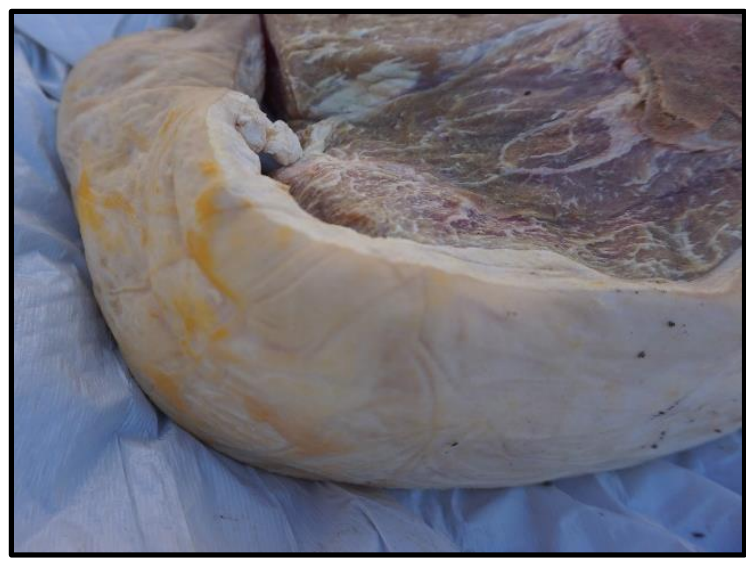

1

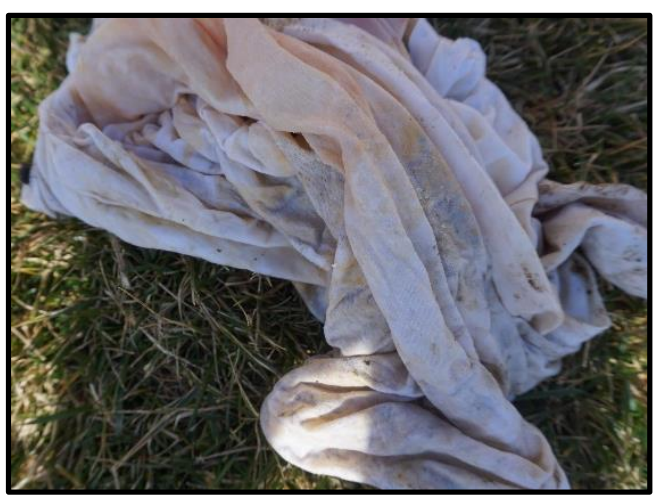

2

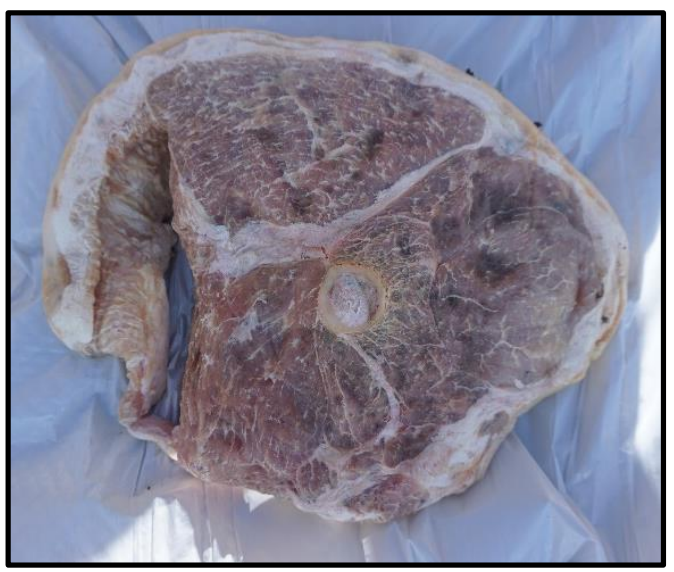

2

c.

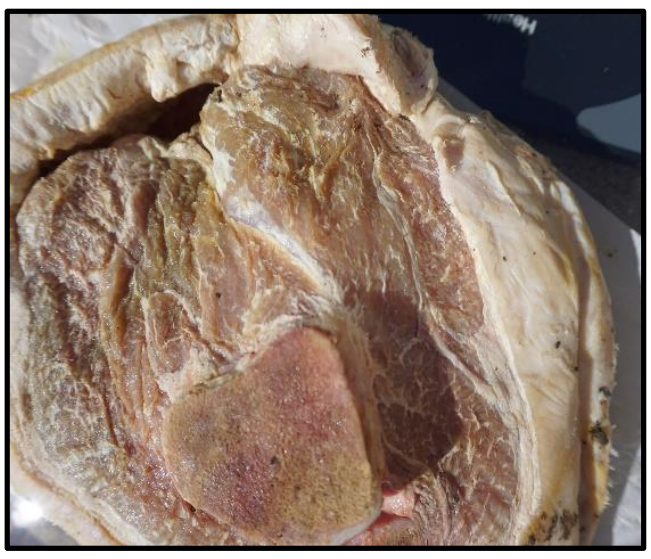

1

Figure 2. Specimen B during the two-month examination: a1. Specimen wrapped in t-shirt; a2. Yellow staining on t-shirt.

b1. Skin stained yellow; b2. Diluted coloration of the specimen.

c1. Change in color of the bone marrow. 
a.

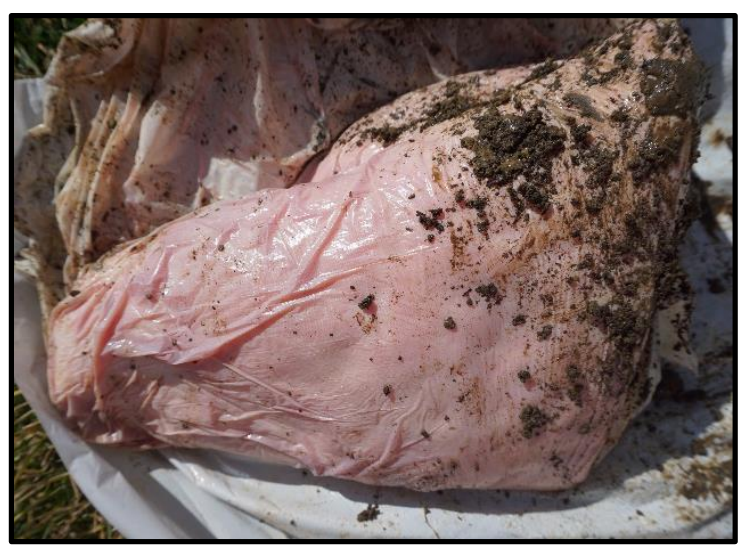

1

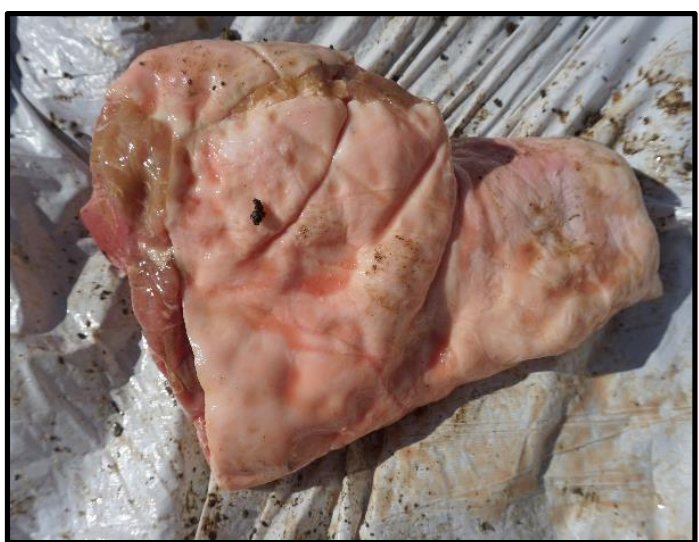

2

b.

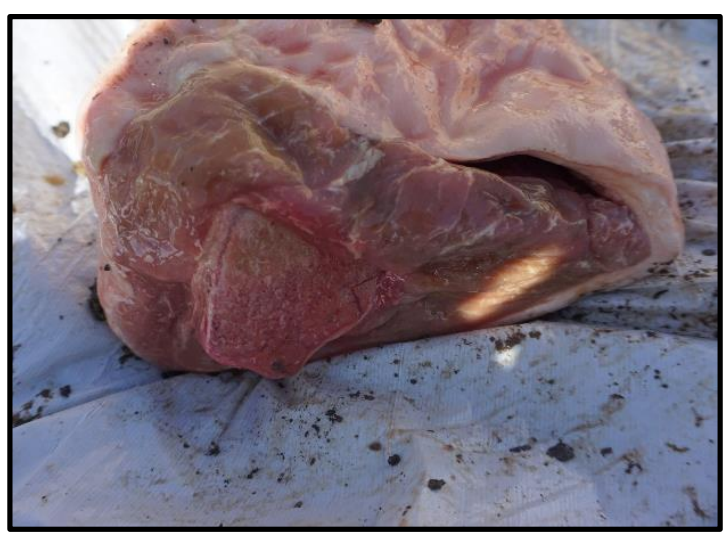

1

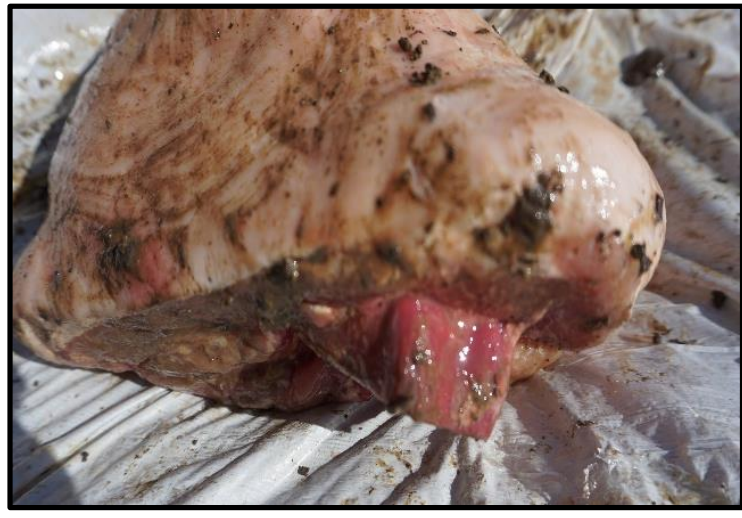

2

Figure 3. Specimen E during the two-month examination: a1. Pink color easily seen through garbage bag; a2. Decompositional fluids cover surface.

b1. Variation in color of the musculature; b2. Bright red coloration of the bone. 
a.

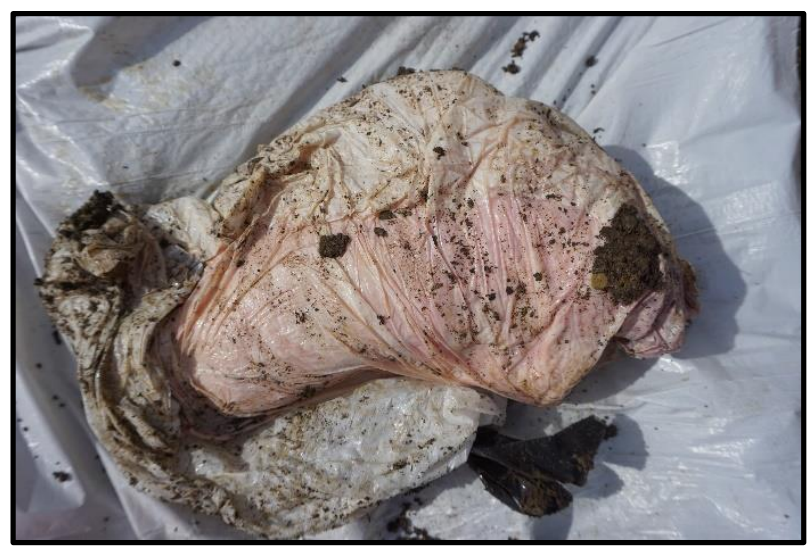

1

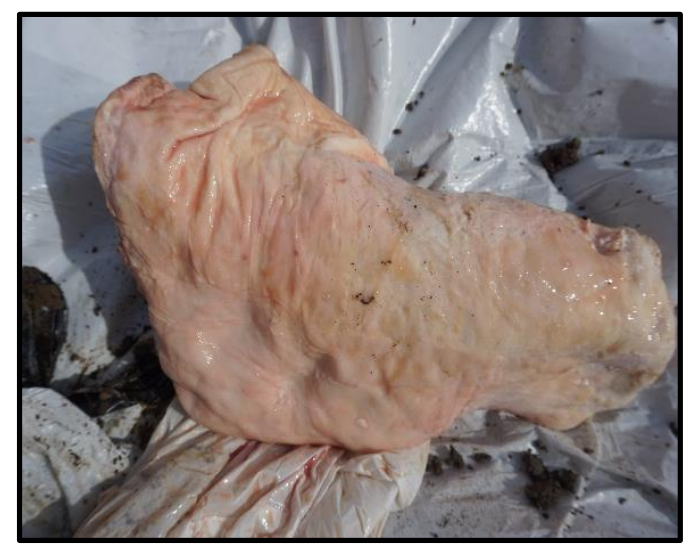

2

b.

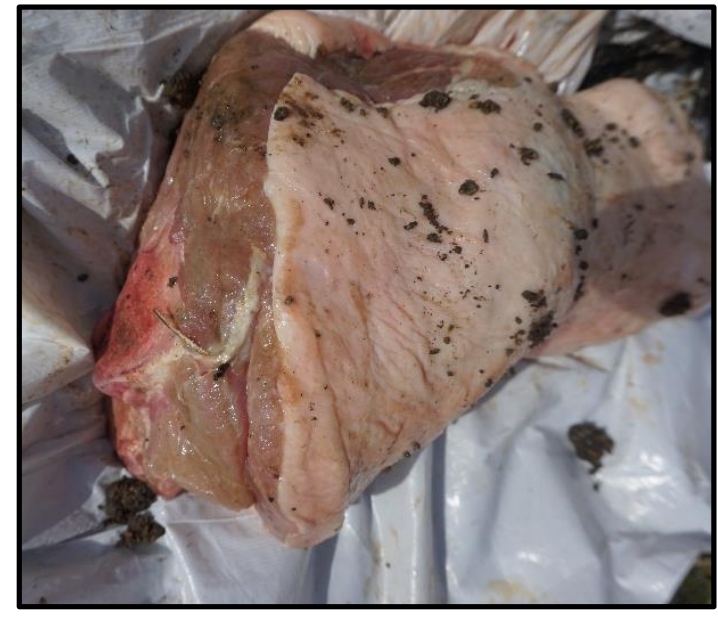

1

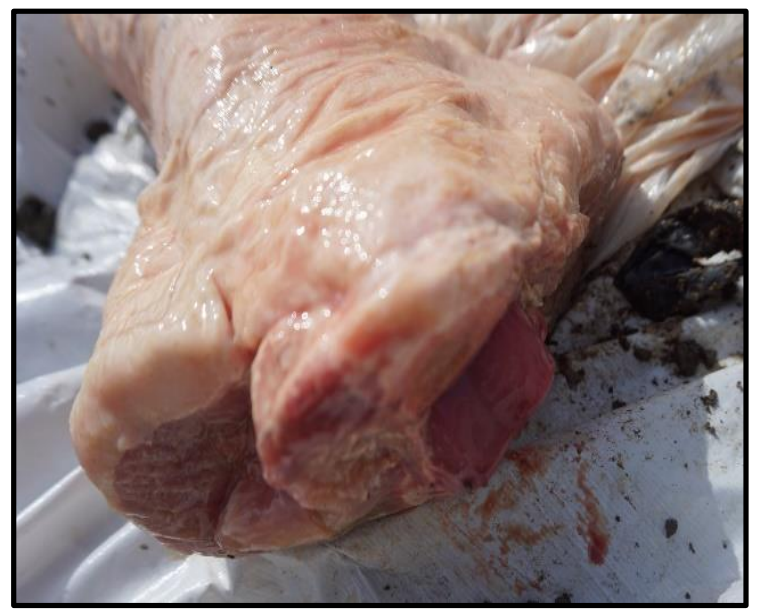

2

Figure 4. Specimen F during the two-month examination: a1. Garbage bag wrapped around the specimen; a2. Portion of the skin turning yellow.

b1. External surface of the specimen; b2. Outer surface of the bone turning bright red. 
a.

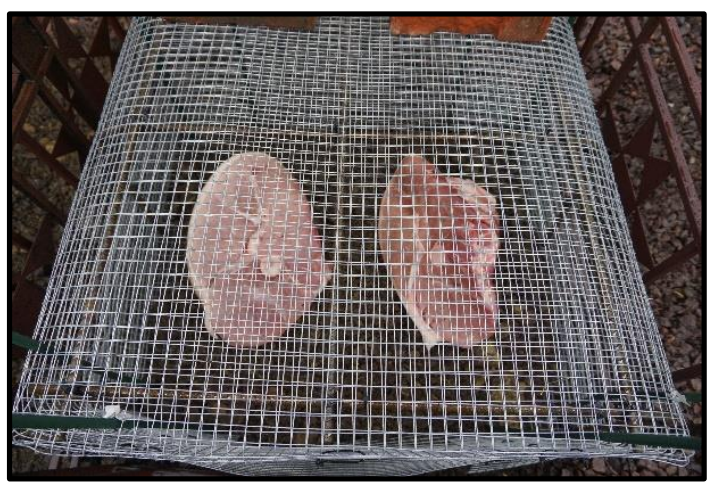

1

b.

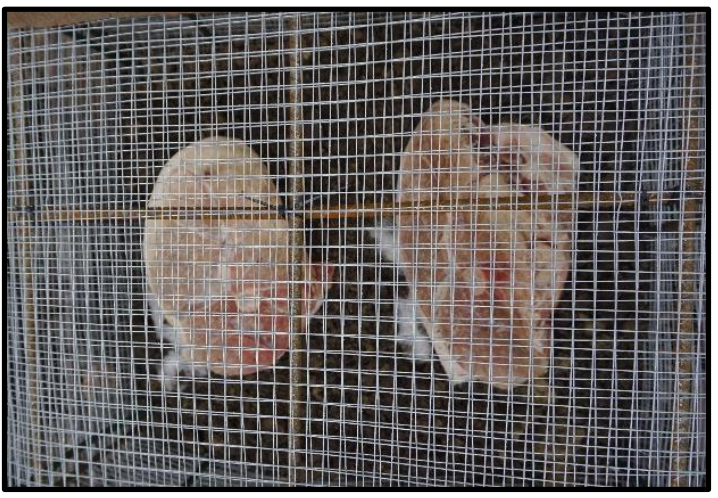

1

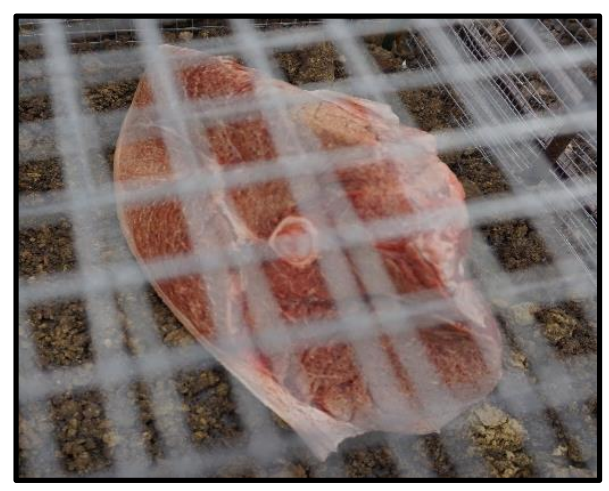

2

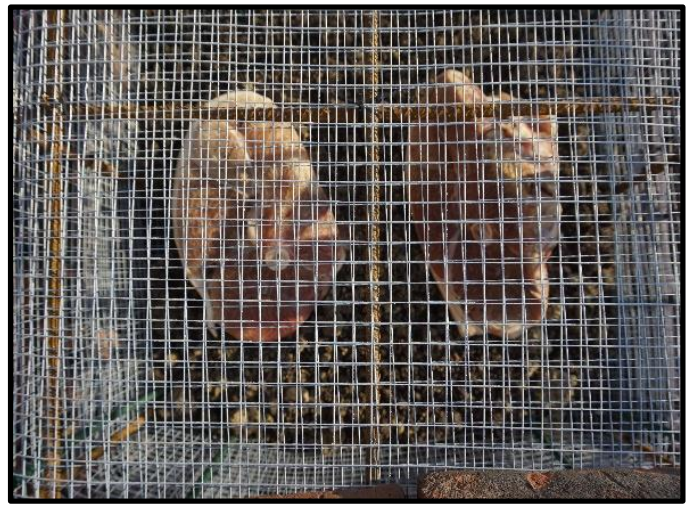

2

c.

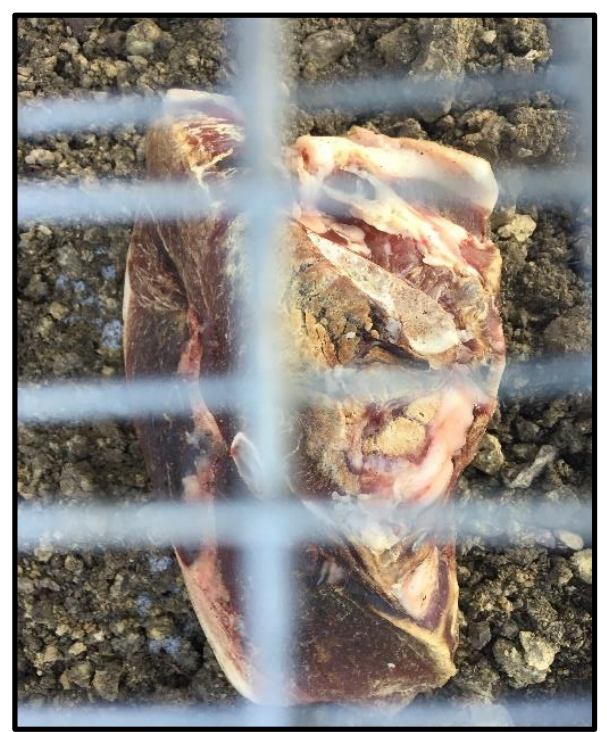

1

Figure 5. Specimen J in January 2018: a1. January 11, 2018; a2. Specimen beginning to desiccate.

b1. Bleached in coloration; b2. Becoming more desiccated and darker in color. c1. Specimen $\mathrm{J}$ at the end of January with some marrow fluid seepage. 
a.

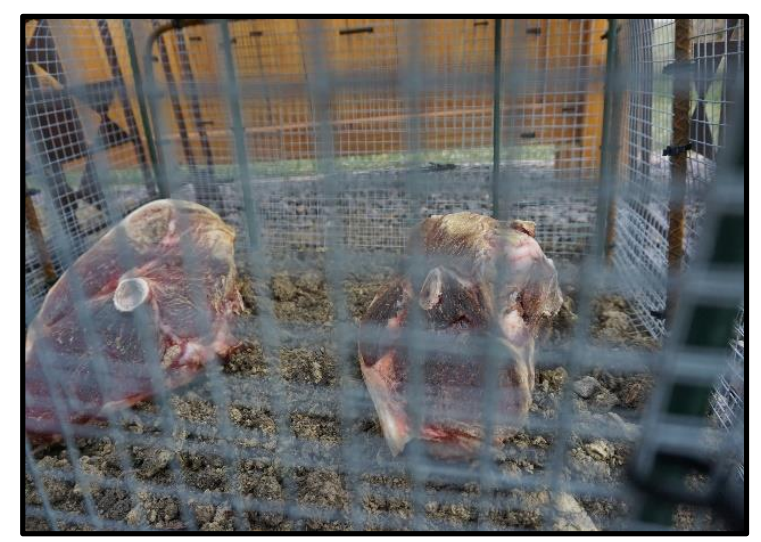

1

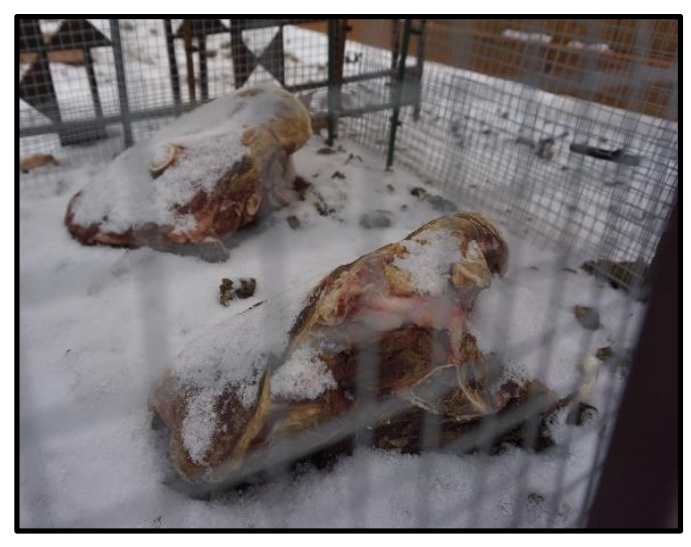

2

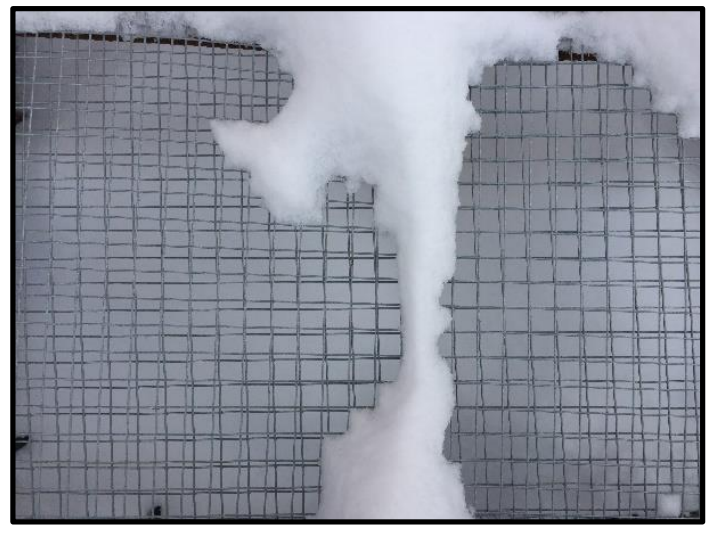

2

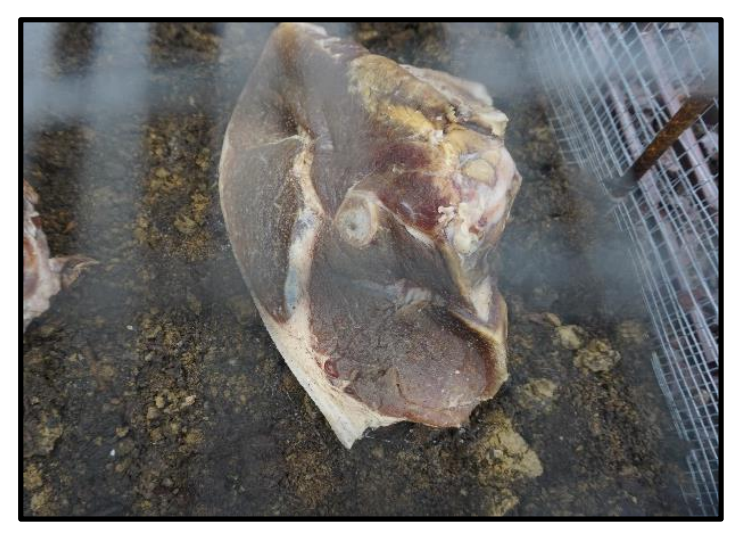

2 
d.

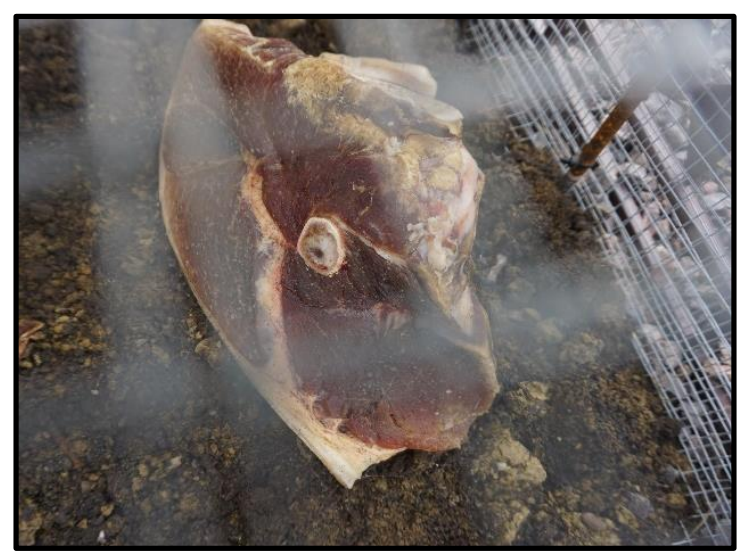

1

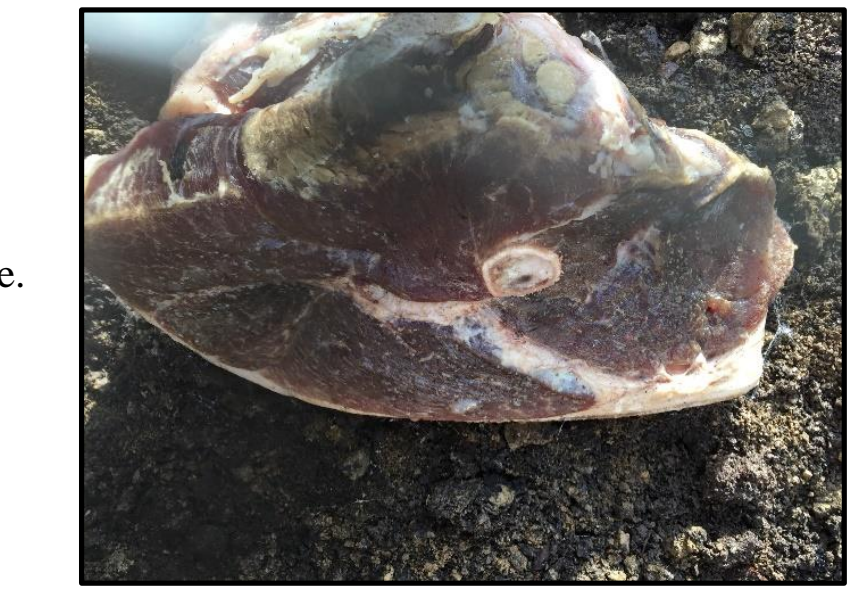

1

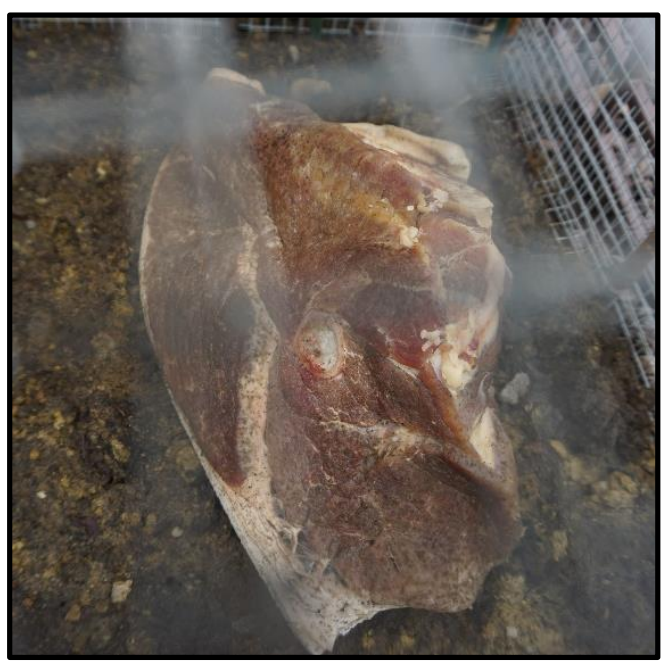

1

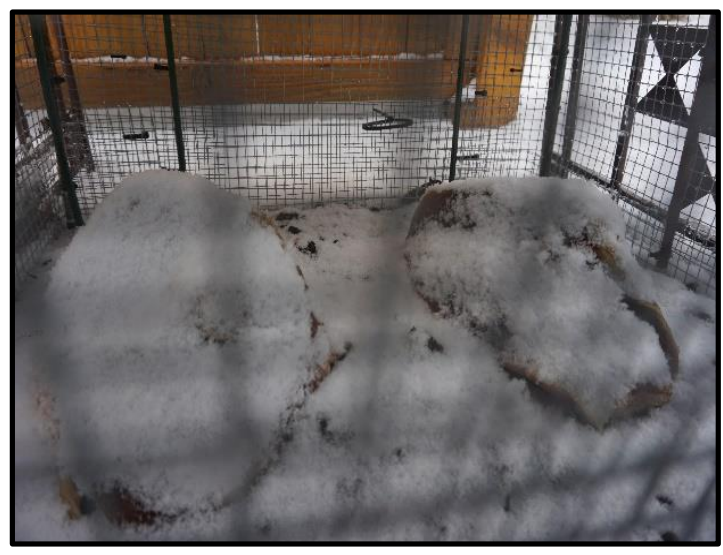

2

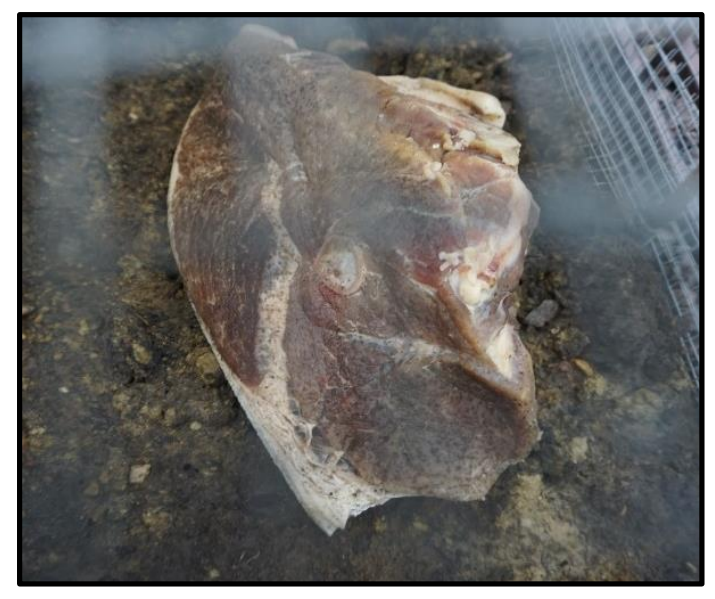

2

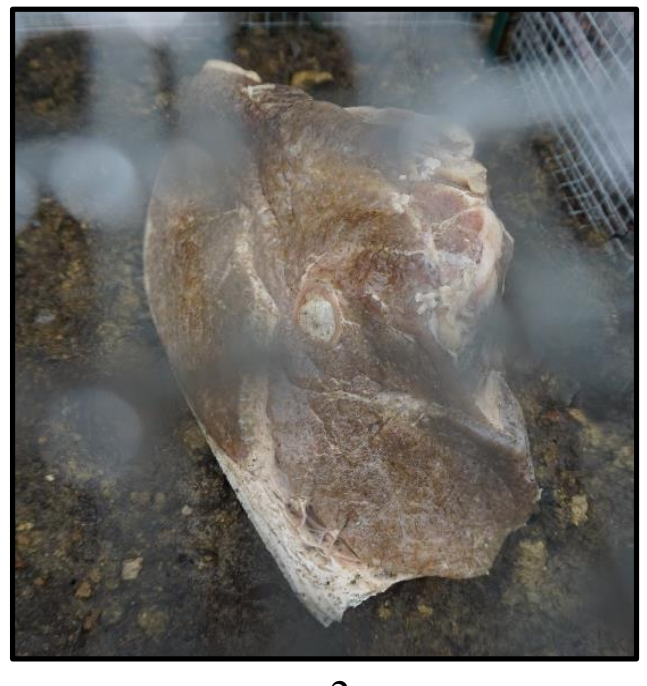

2 

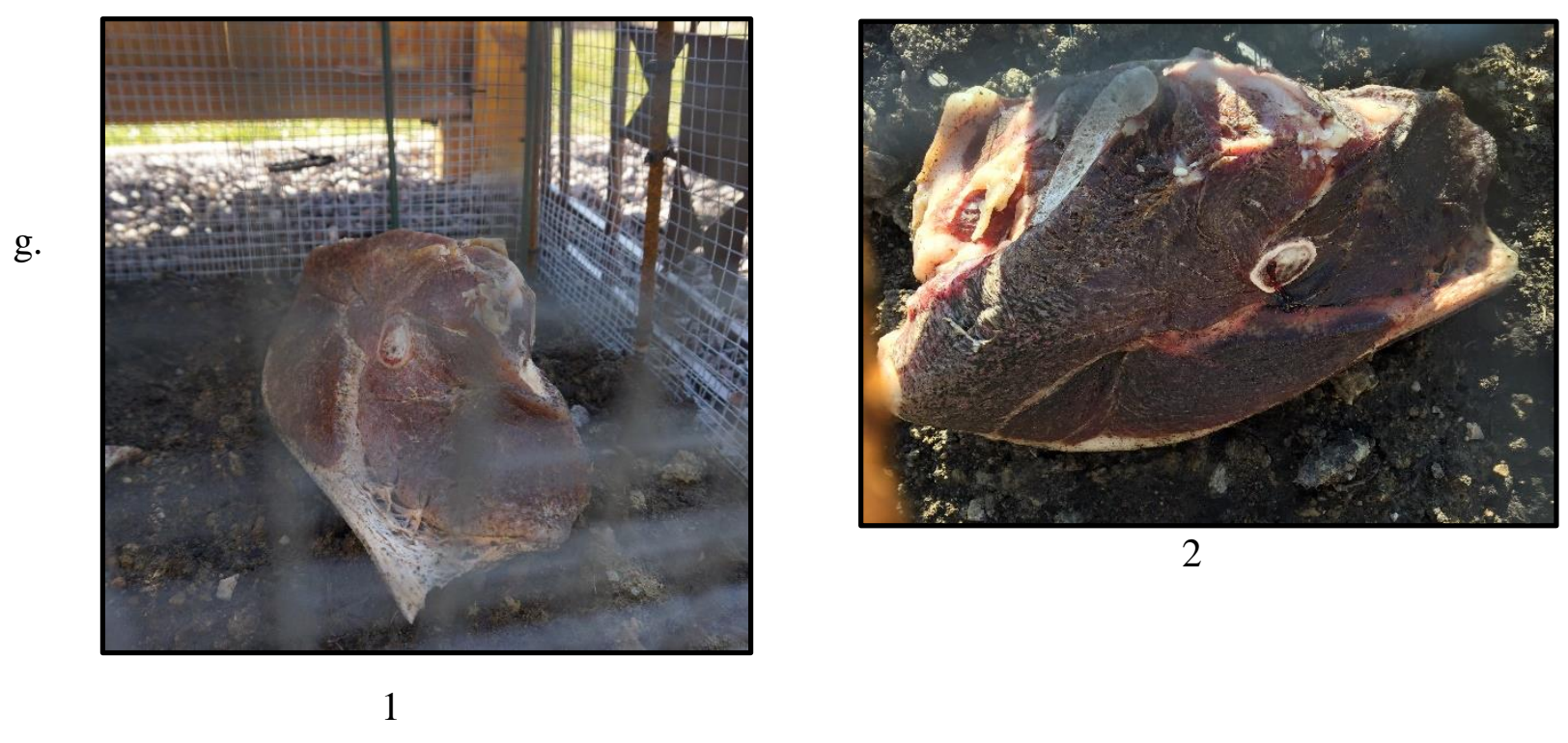

\section{2}

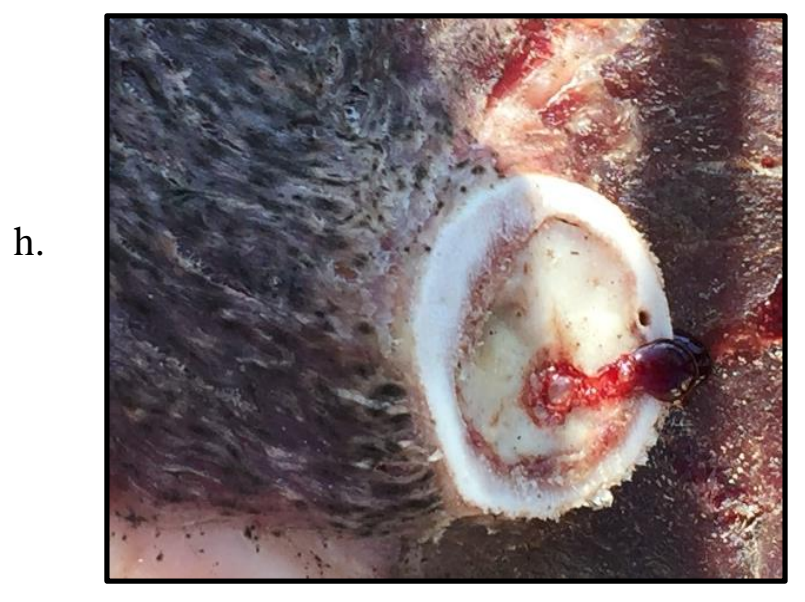

1

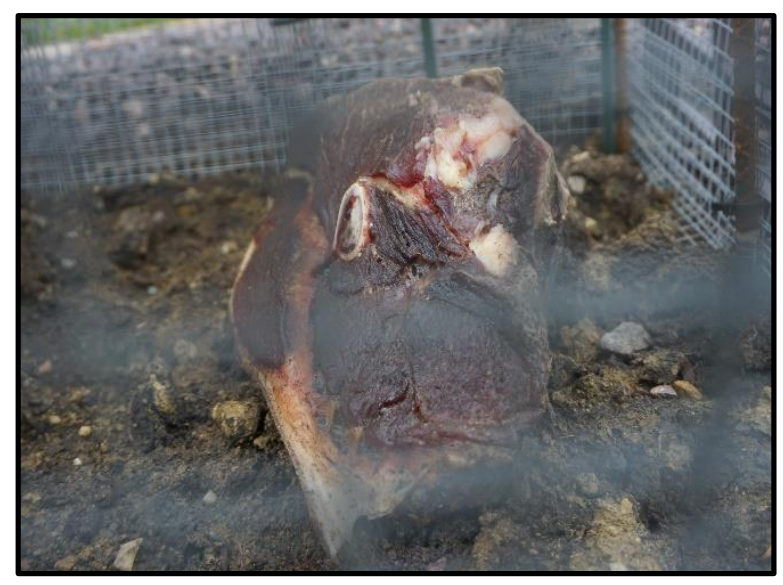

2

Figure 6. Specimen J in February 2018: a1. Specimen desiccating further; a2. Light snow visible.

b1. Large portion of specimen covered in snow; b2. Specimen completely covered. c1. Specimen J after the snow melted; c2. Bleached coloration of he musculature. d1. External surface becoming darker; d2. Specimen covered in snow. e1. Further desiccation of musuclature; e2. Skin is starting to detatch from muscle. f1. Fluids being emitted from bone marrow; f2. Bleached in color from the rain. g1. Specimen has darkened in color; g2. Desiccated external surface.

h1. Red fluid emitted from bone marrow; h2. Receeding of musculature around bone. 
a.

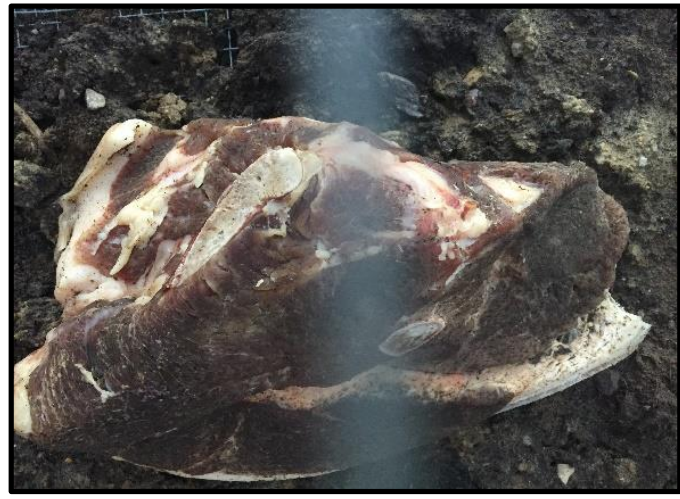

1

b.

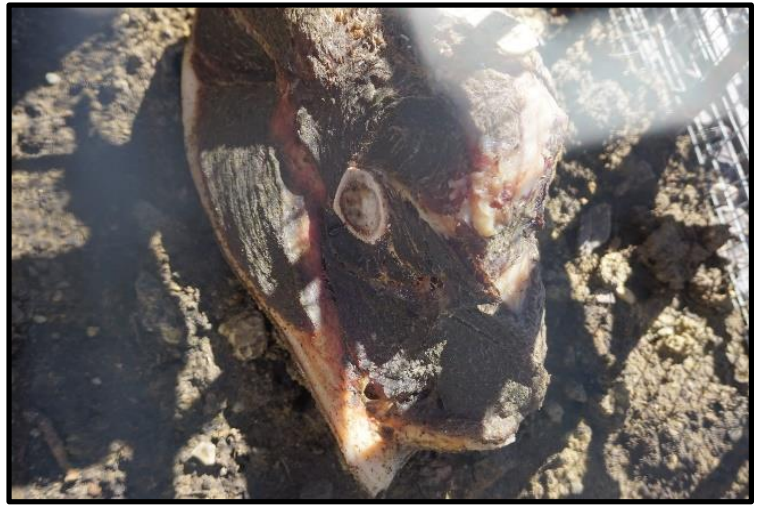

1

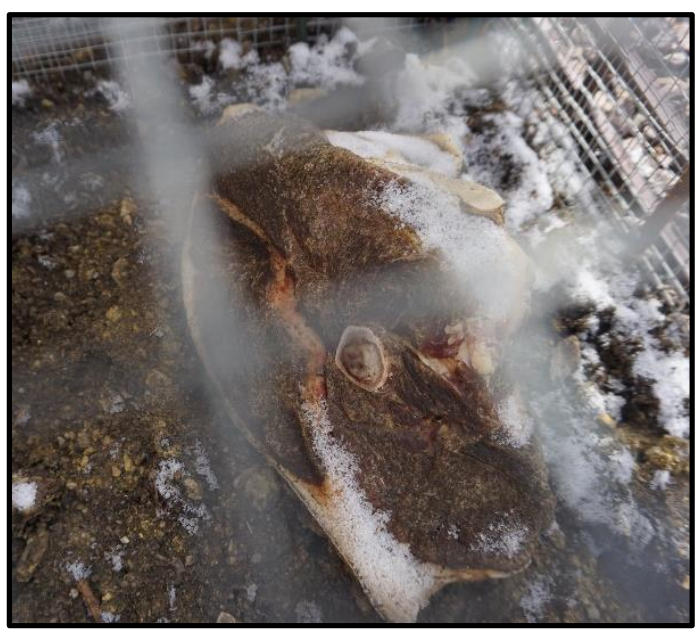

1

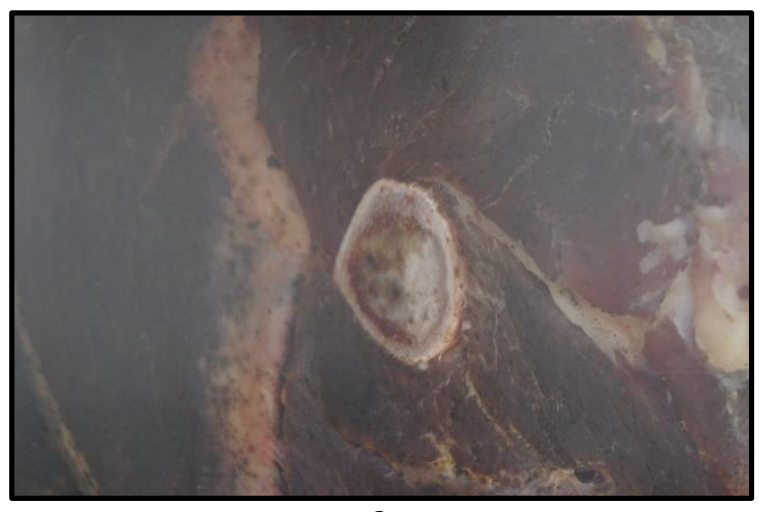

2

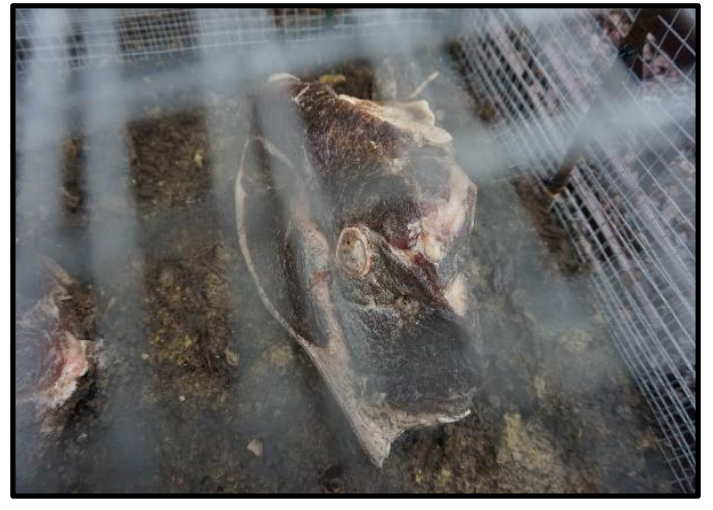

2

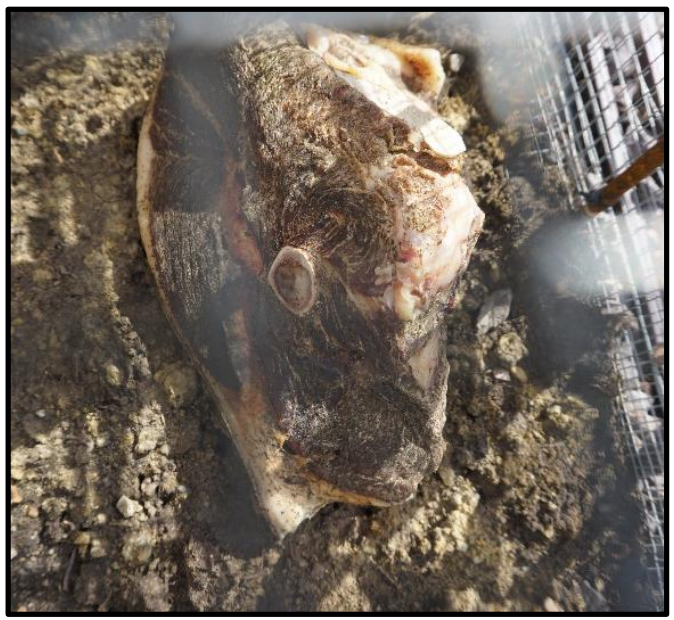

2

Figure 7. Specimen J in March 2018: a1. Contrast in coloration of the specimen; a2. Fat and marrow is turning colors.

b1. External surface appearing desiccated; b2. Specimen is saturated from the rainfall. c1. Freezer burn on the musculature; c2. Specimen is darker in color. 
a.

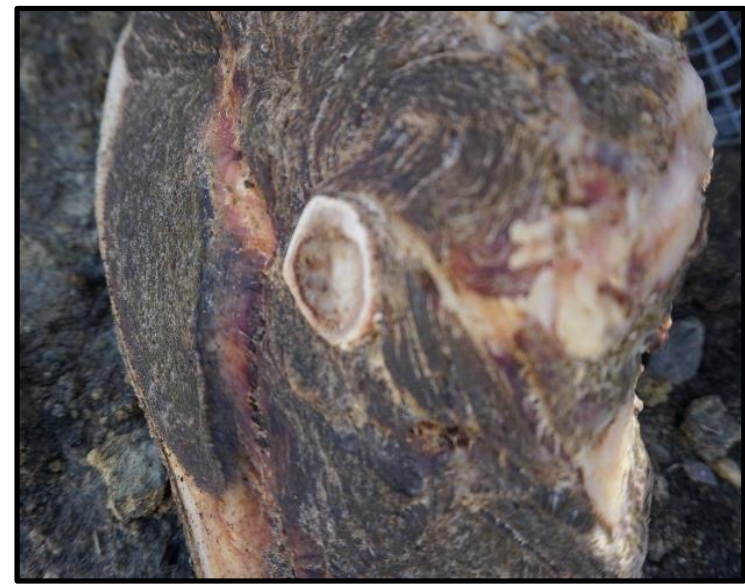

1

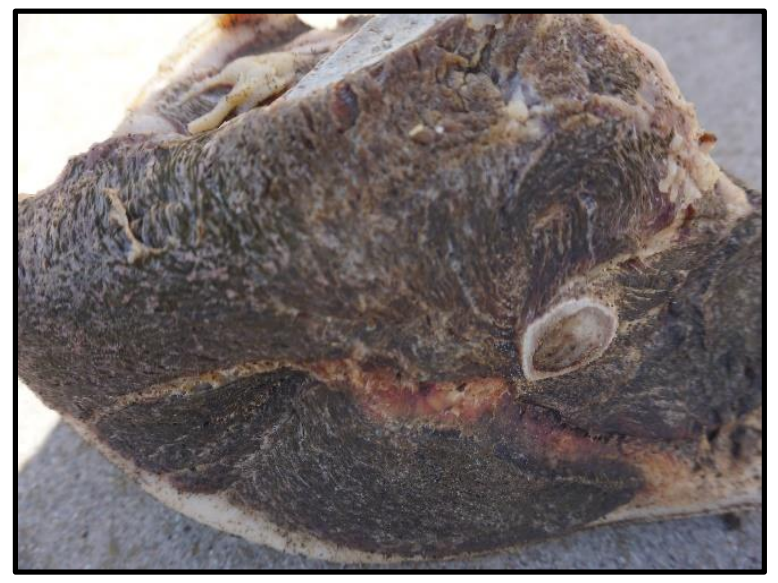

2

b.

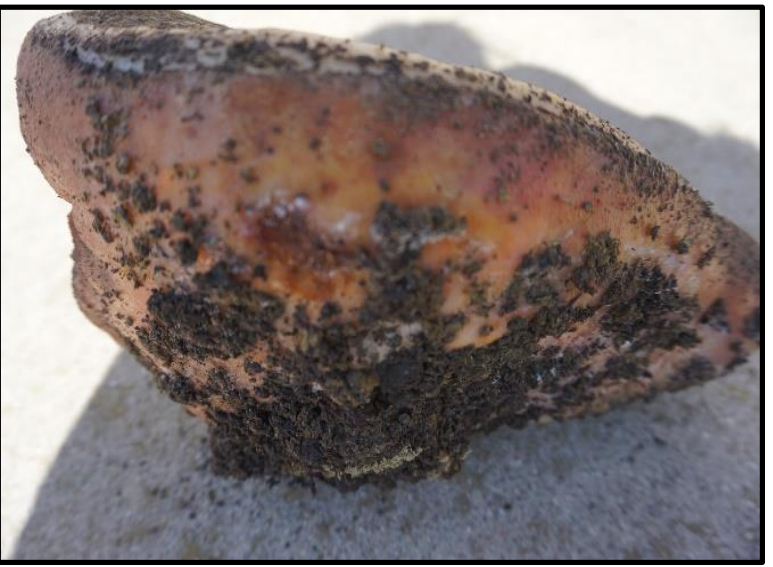

1

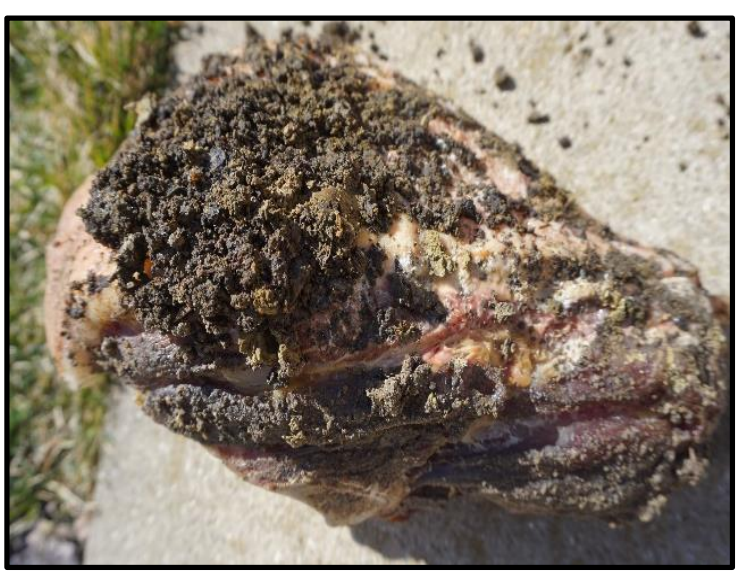

2

Figure 8. Specimen J during the two-month examination: a1. White streaks of fat easily visible; a2. Variations in colorations across the entire specimen.

b1. Skin has turned more yellow; b2. More moisture present on the underside of the specimen. 
a.

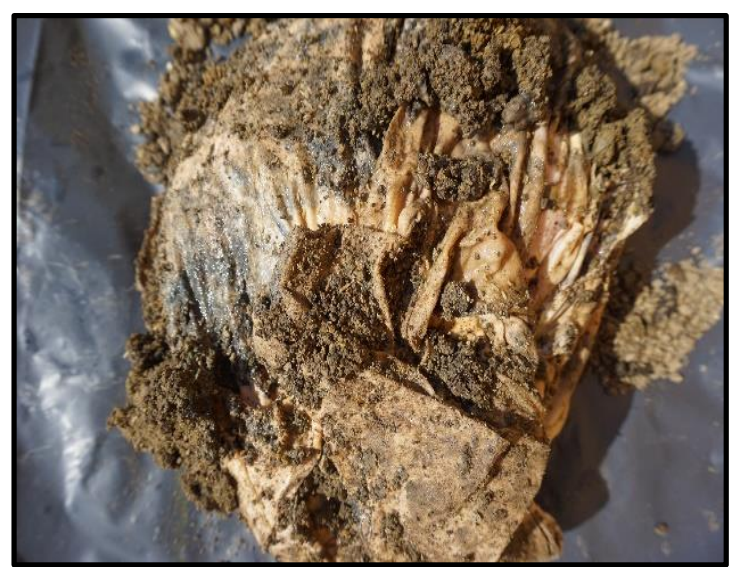

1

b.

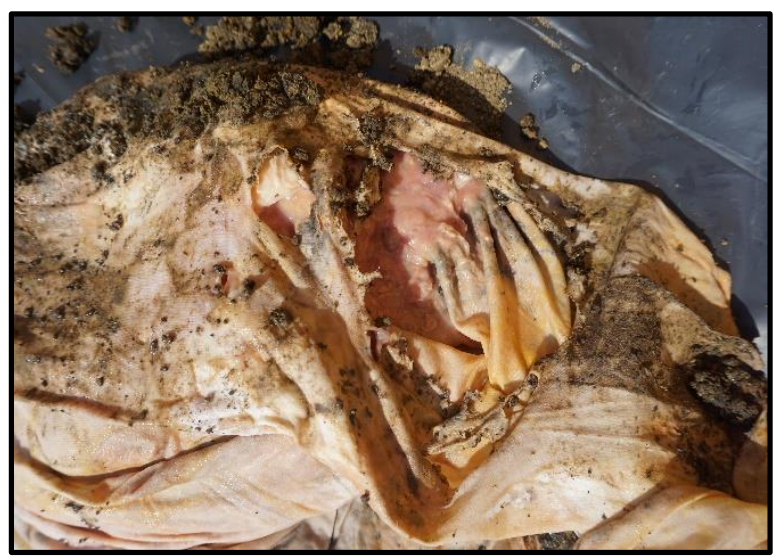

1

C.

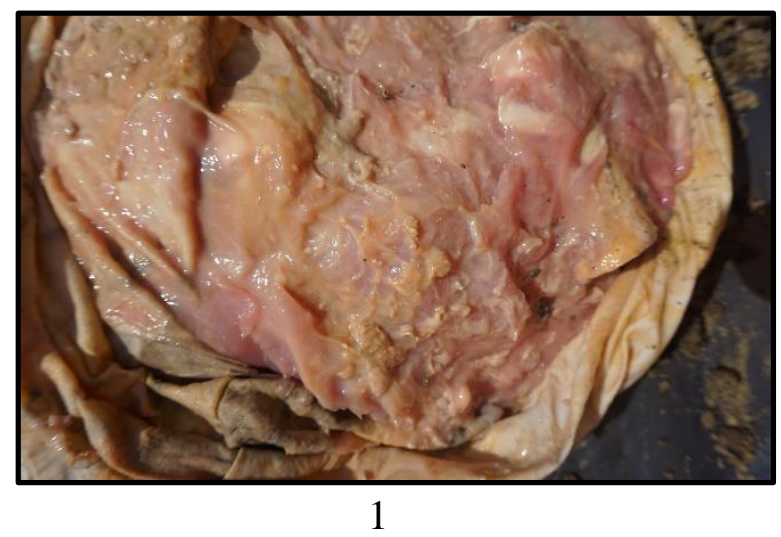

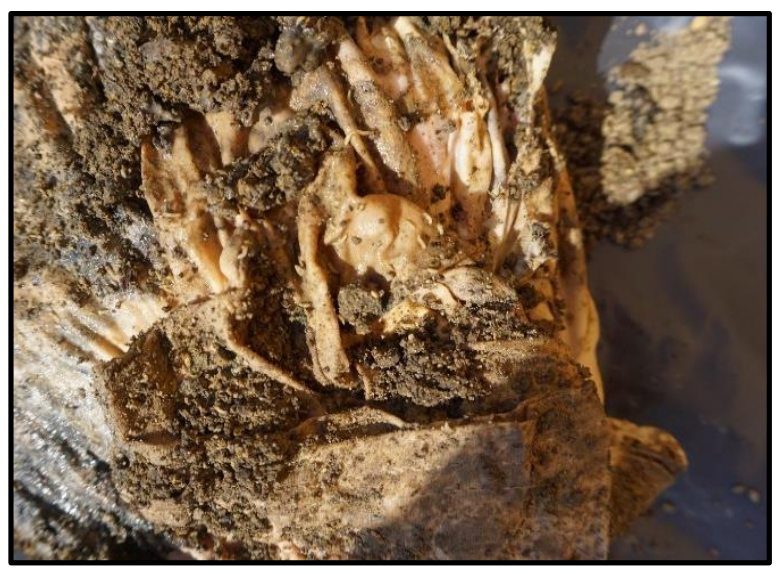

2

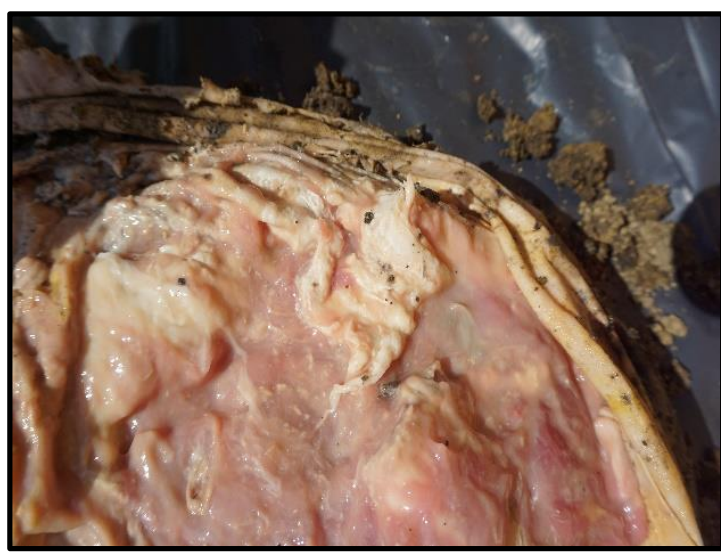

2

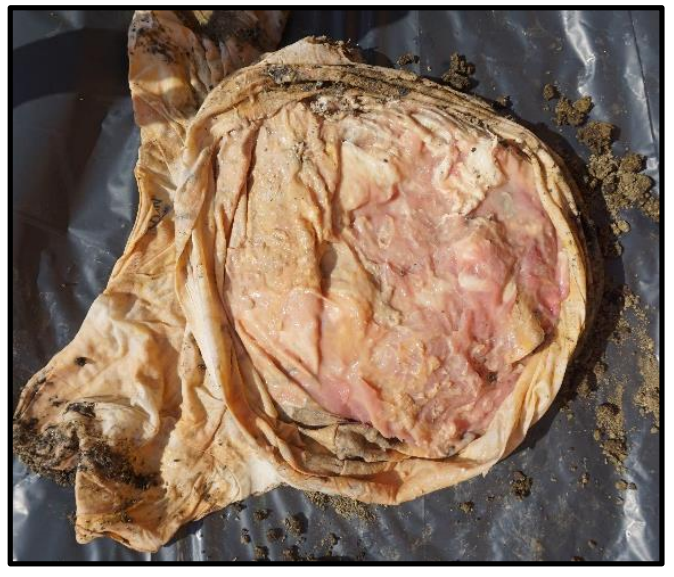

2

Figure 9. Specimen $\mathrm{C}$ during the four-month examination: a1. Areas of staining throughout t-shirt; a2. Maggots observed on t-shirt.

b1. Hole created in the t-shirt; b2. Area of skin is still identifiable.

c1. Bone resting on top of liquefied specimen; $c 2$. Entirety of specimen in t-shirt. 
a.

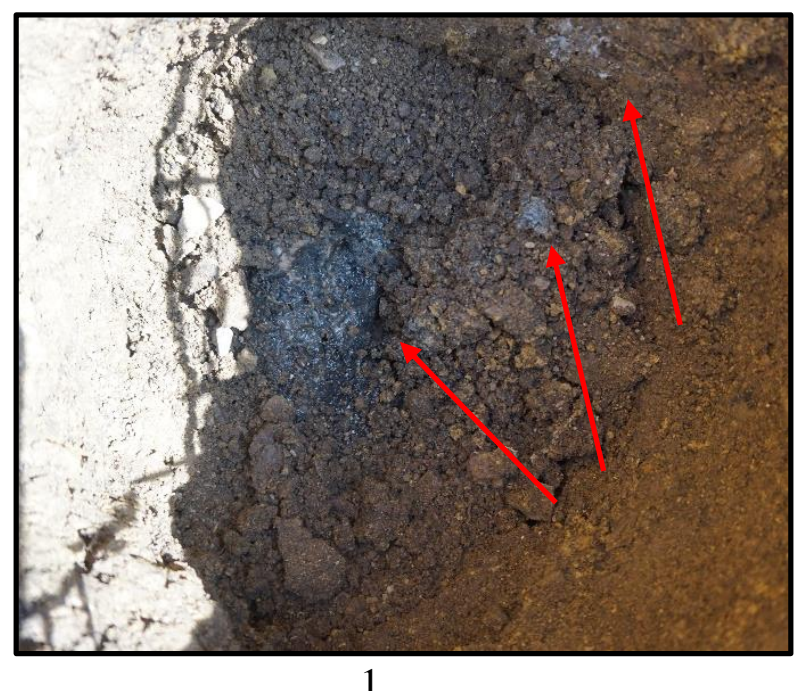

b.
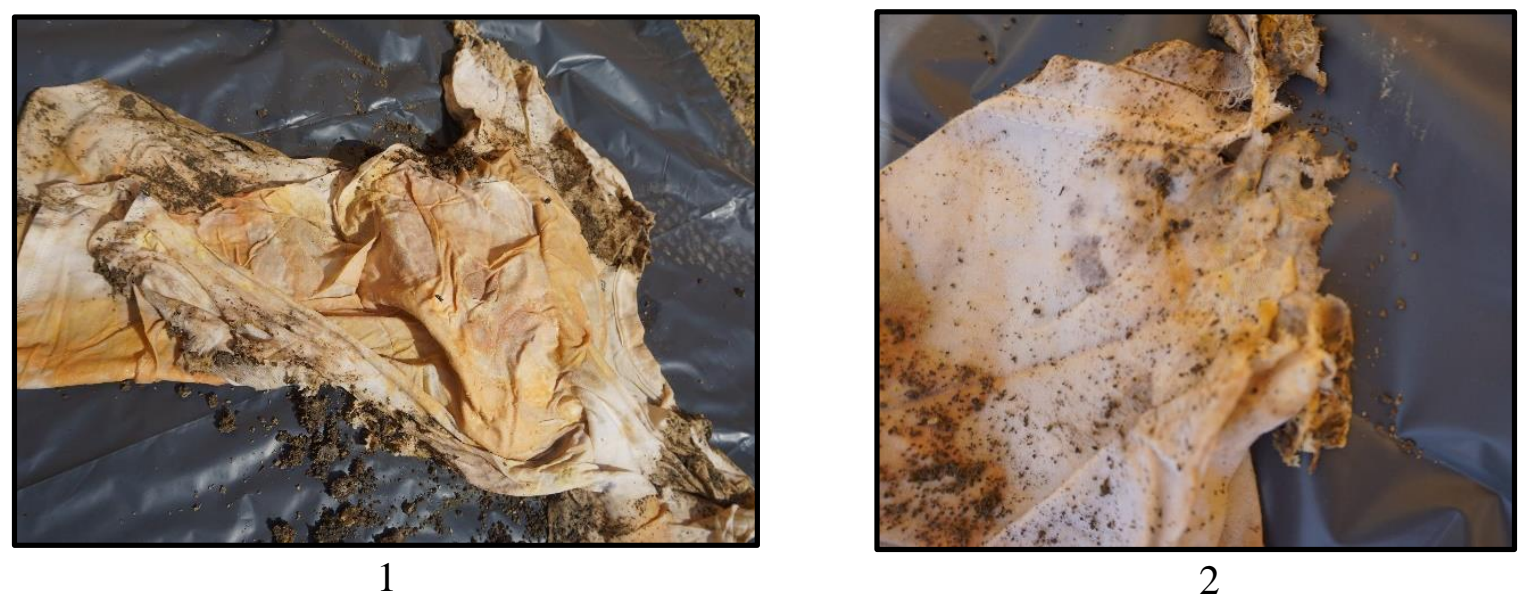

2

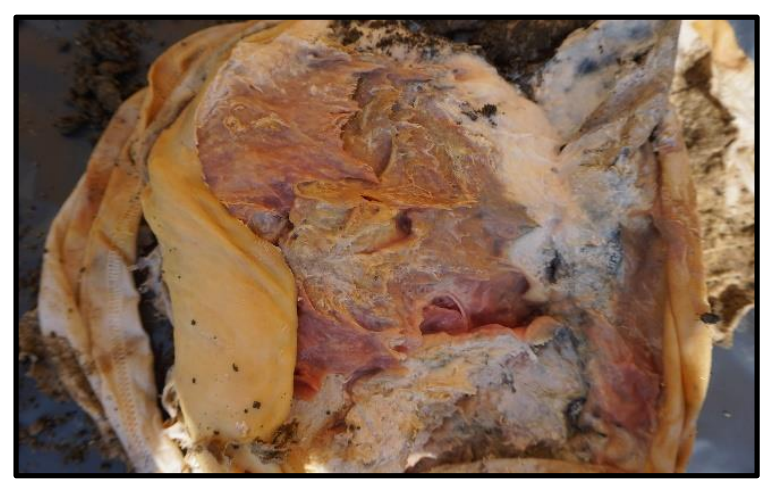

1

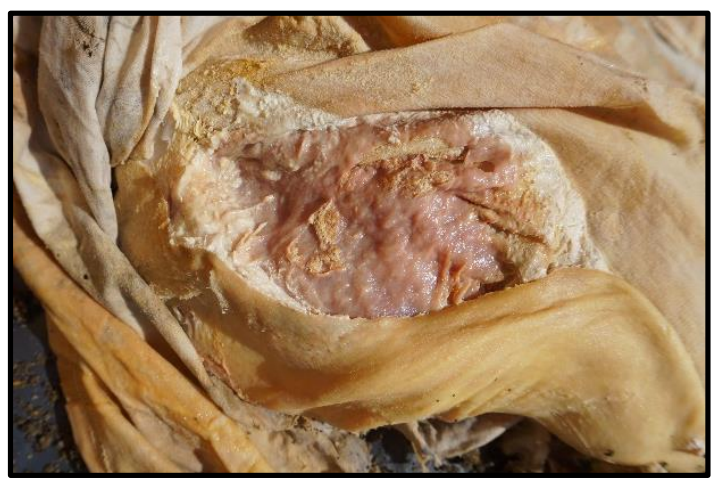

2

Figure 10. Specimen D during the four-month examination: a1. Fluids remaining in the soil after specimen removal.

b1. Yellow staining of the t-shirt; b2. Breakdown of the t-shirt with holes forming. c1. Skin has remained intact around the specimen; c2. Musculature is diluted in color. 
a.

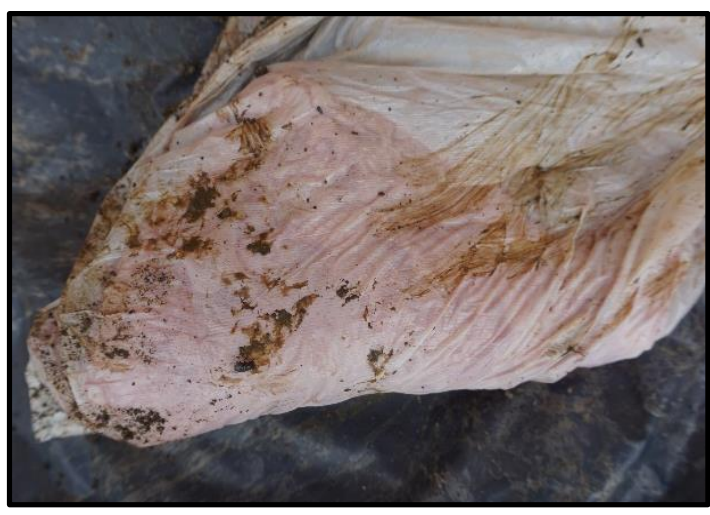

1

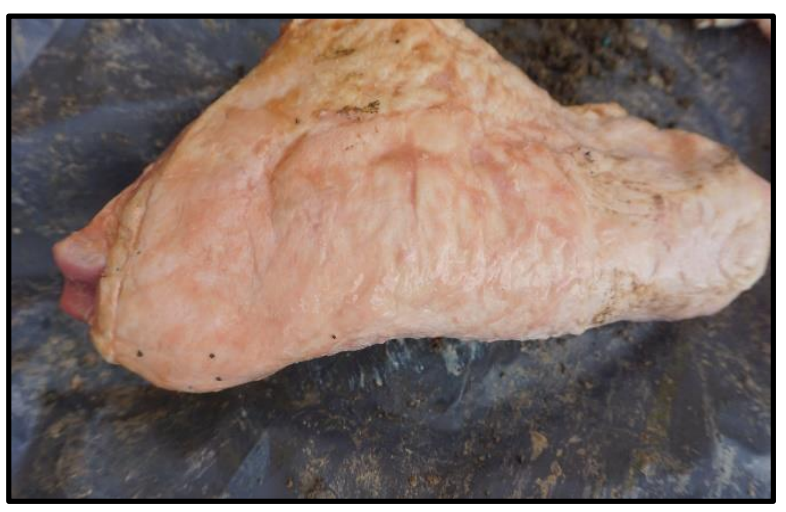

2

2

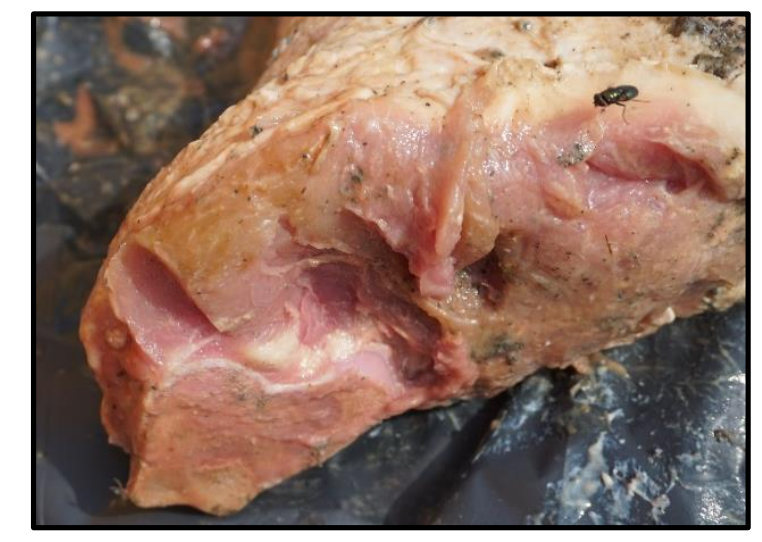

c.

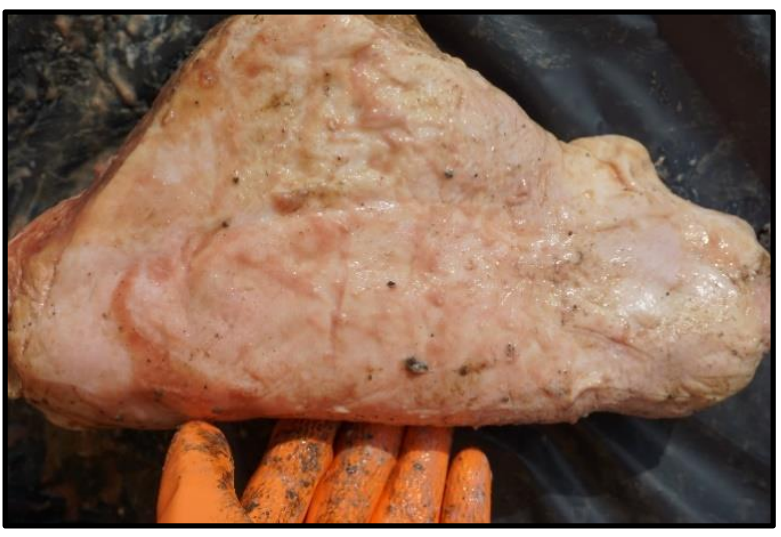

1

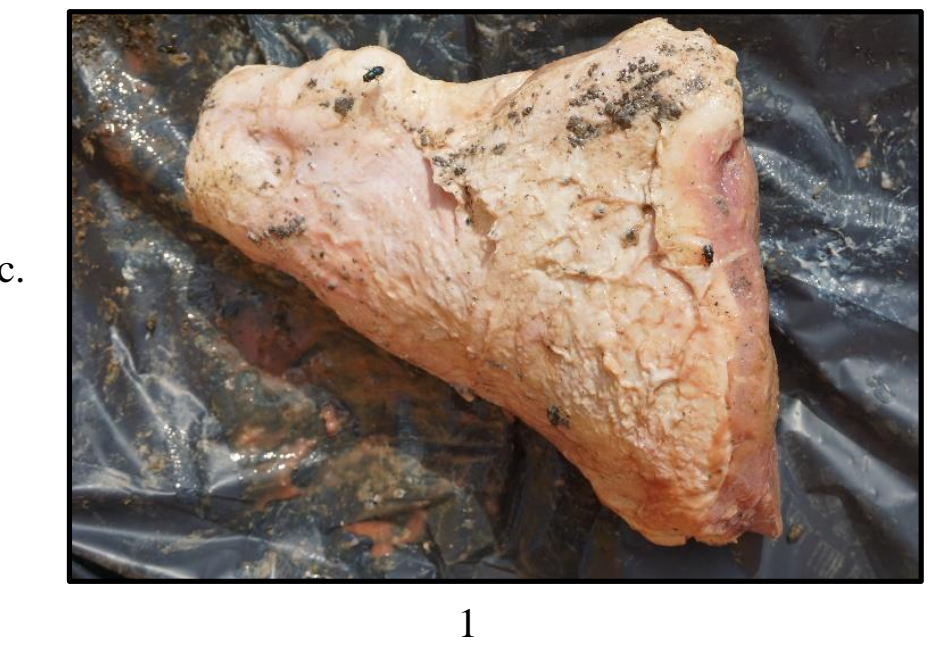

Figure 11. Specimen G during the four-month examination: a1. Color of the specimen can be seen through the garbage bag; a2. Pink decompositional fluids accumulated on skin. b1. Areas of skin had turned yellow; b2. Change in color of the musculature. c1. Skin had started to breakdown after handling. 
a.

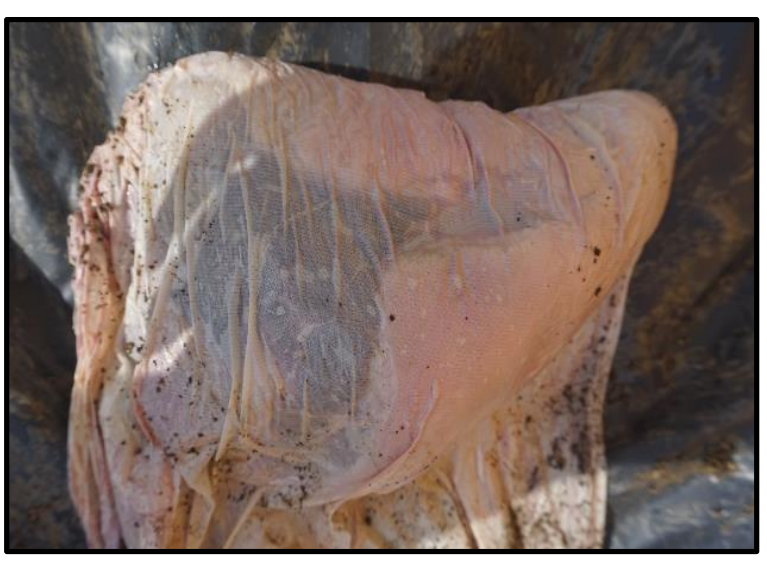

1

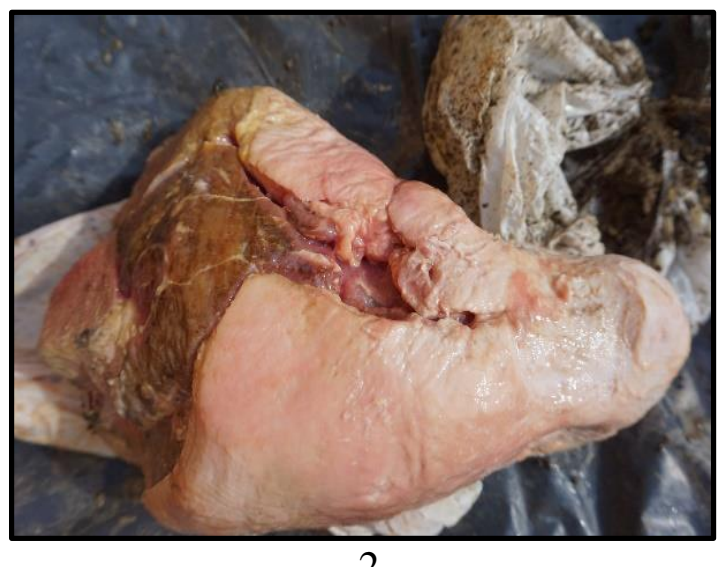

2

b.

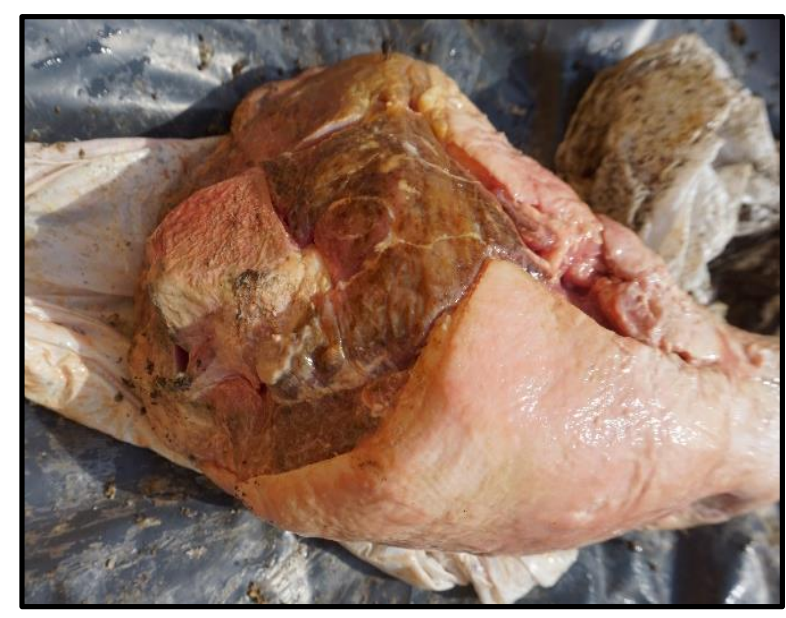

1

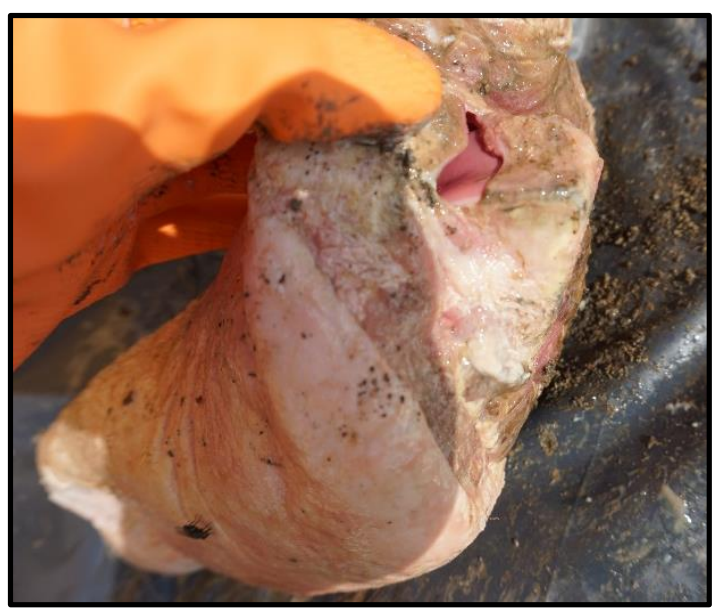

2

Figure 12. Specimen H during the four-month examination: a1. Specimen can be seen through the garbage bag; a2. Skin has become pinker in color. b1. Musculature turned darker brown in coloration; b2. Outer portion of the bone turned bright red. 
a.

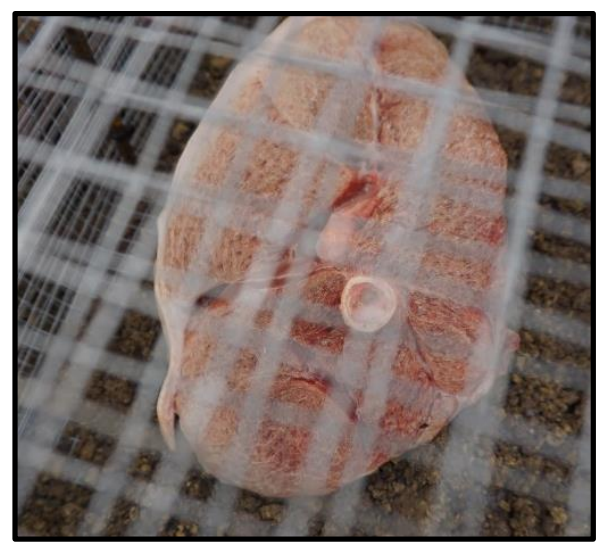

1

b.

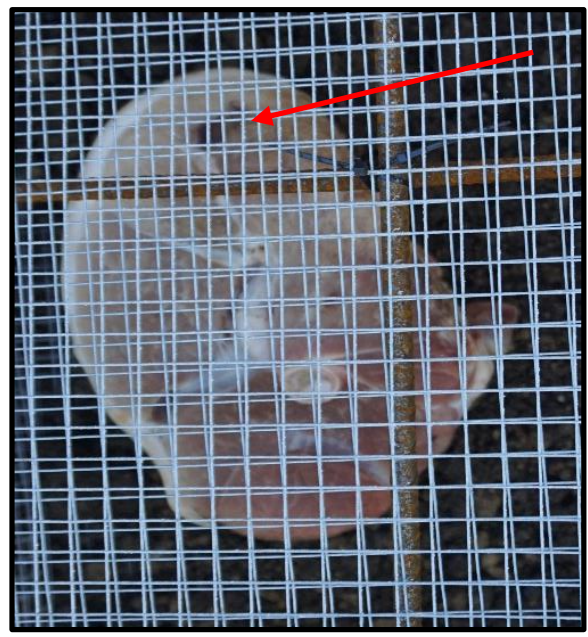

1

c.

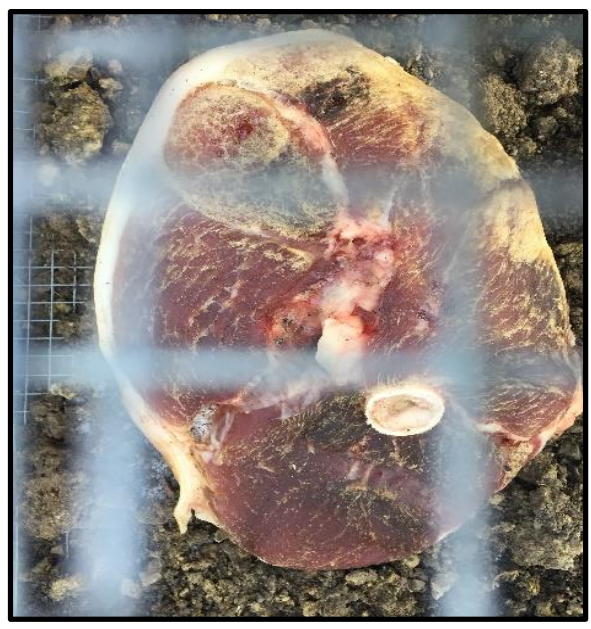

1

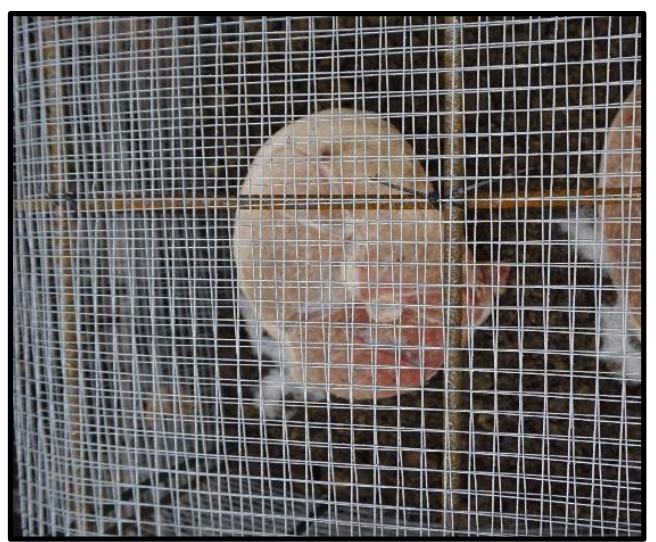

2

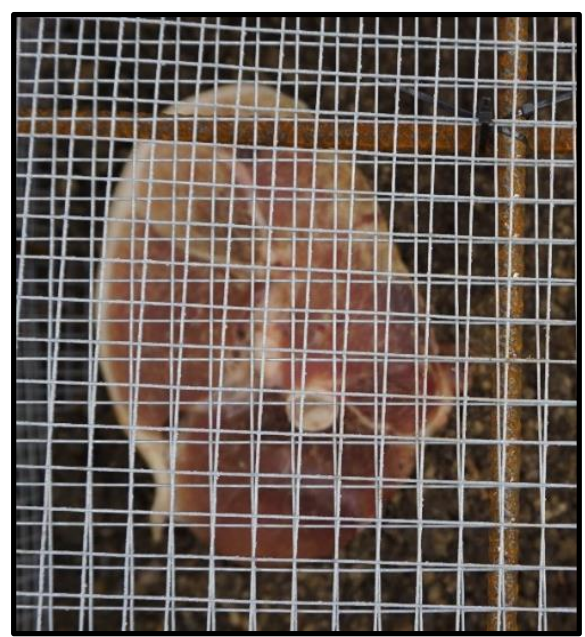

2

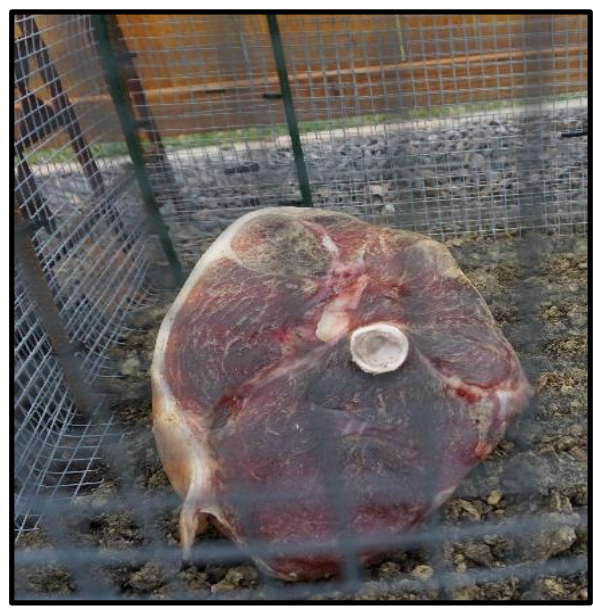

2

Figure 13. Specimen I in January 2018: a1. Freezer burn/desiccation on musculature; a2. Variations in color of the specimen.

b1. Dark spot formed on proximal end of musculature; b2. Darker coloration c1. Musculature becoming more desiccated; c2. Some areas appearing blackened 

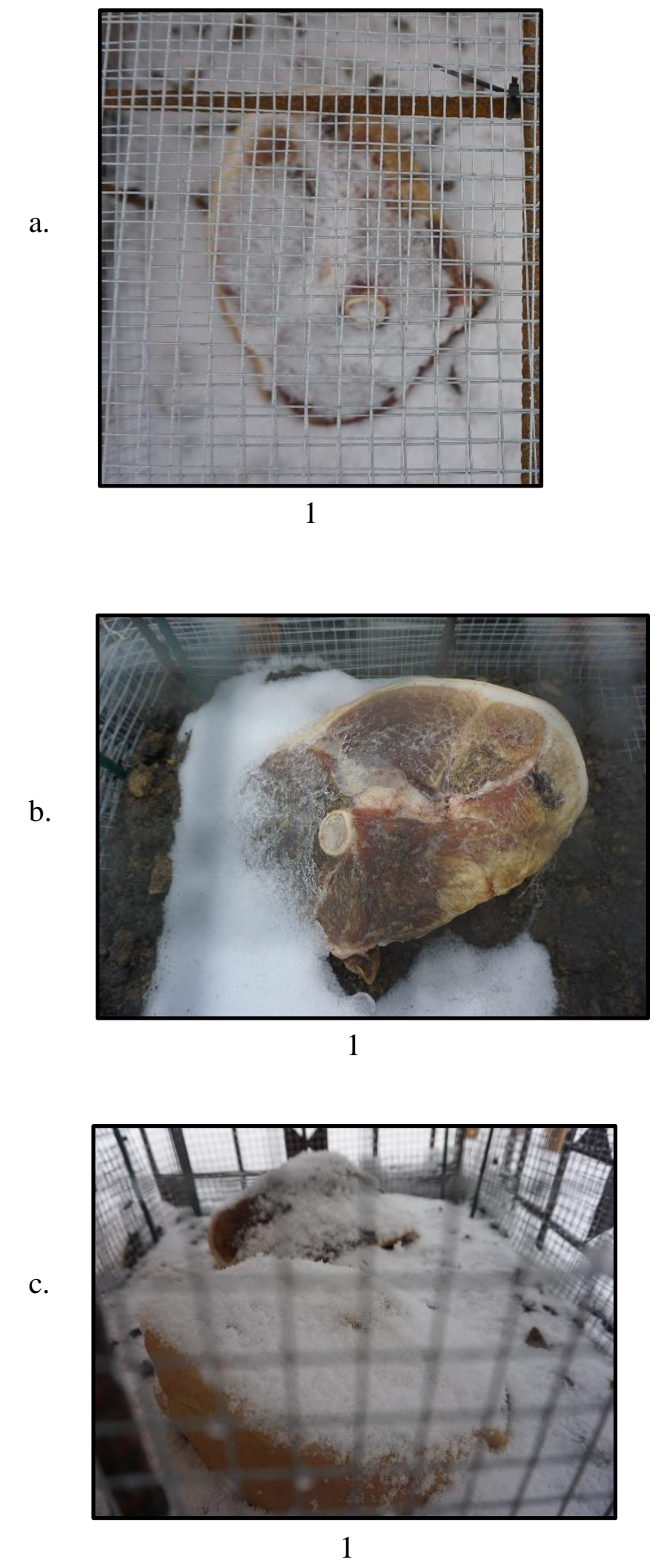
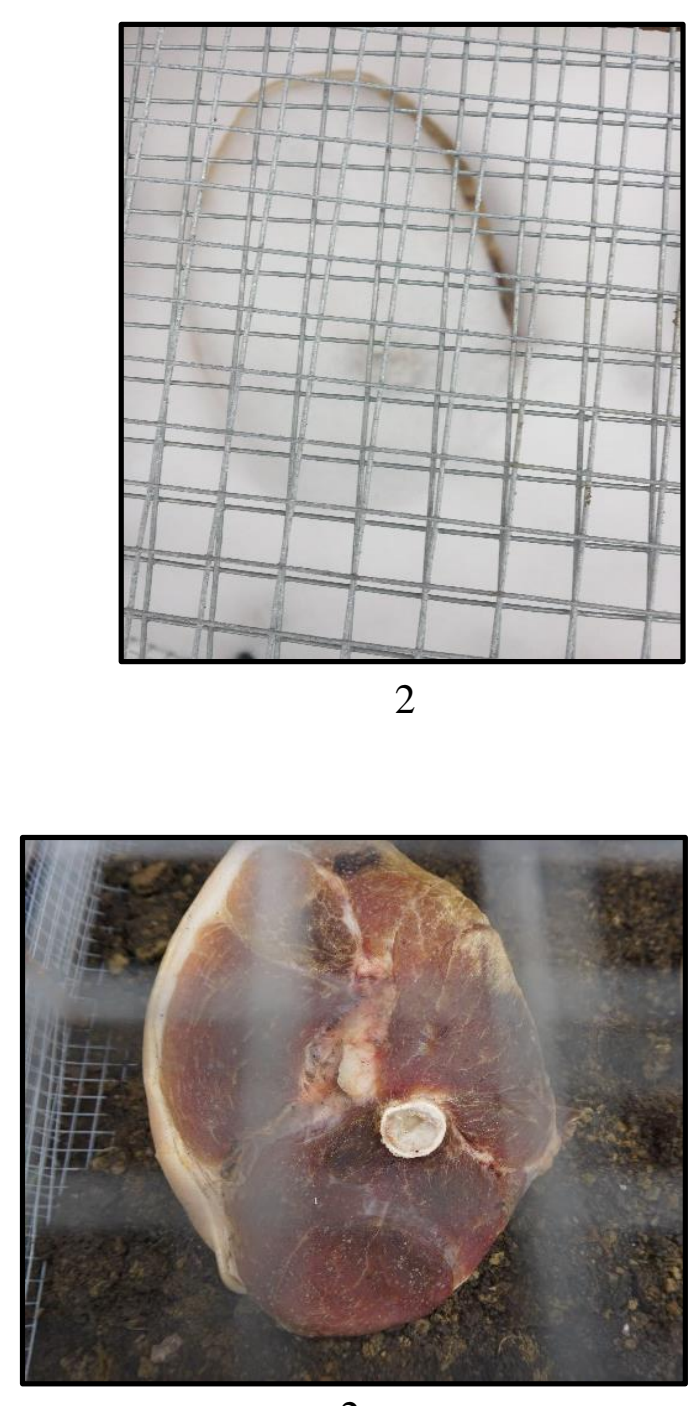

2

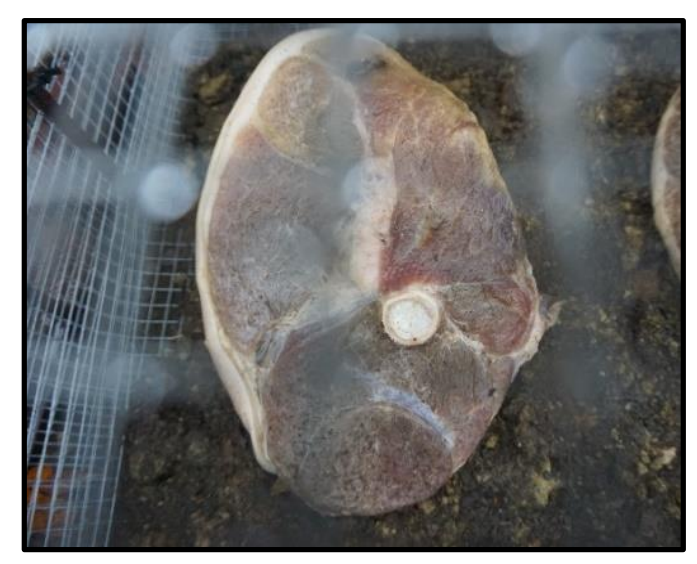

2 

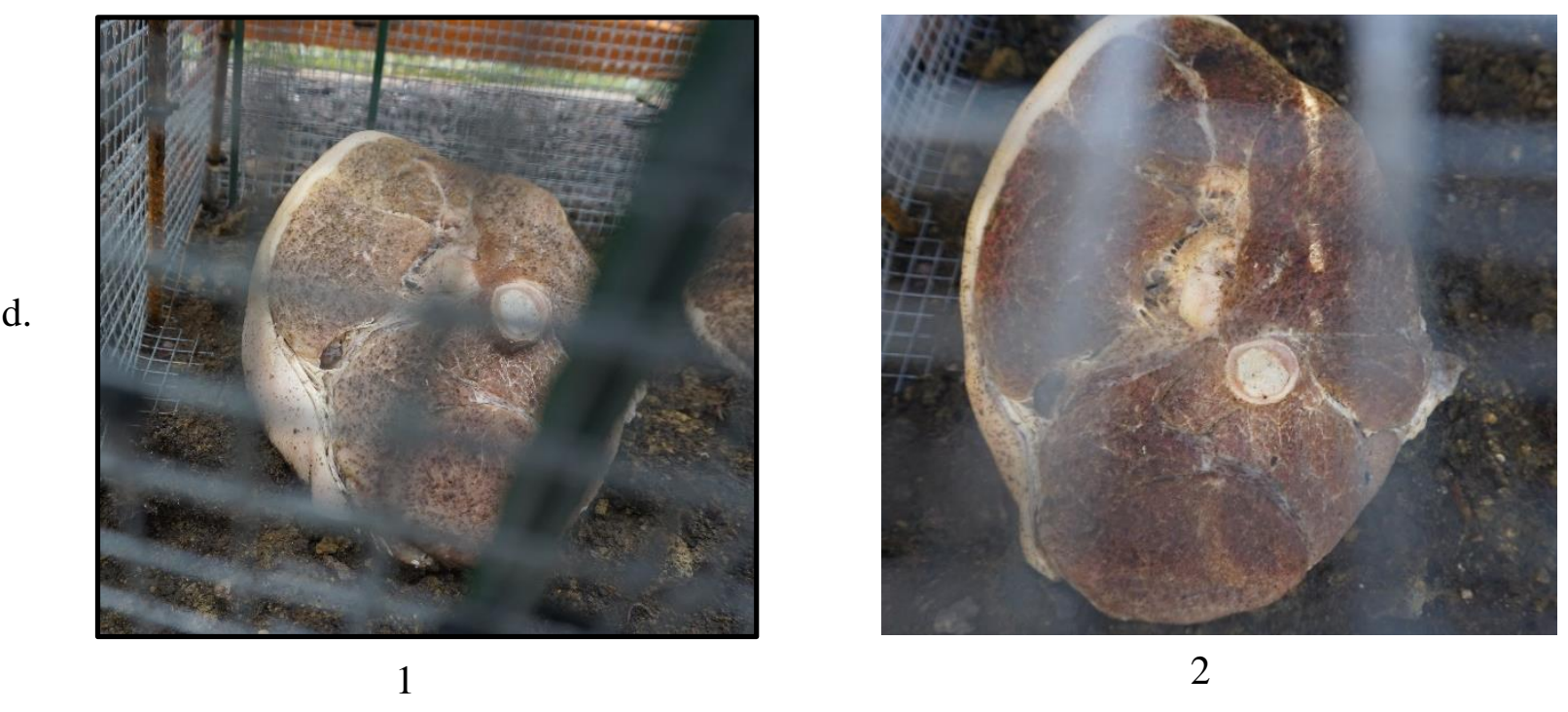

2

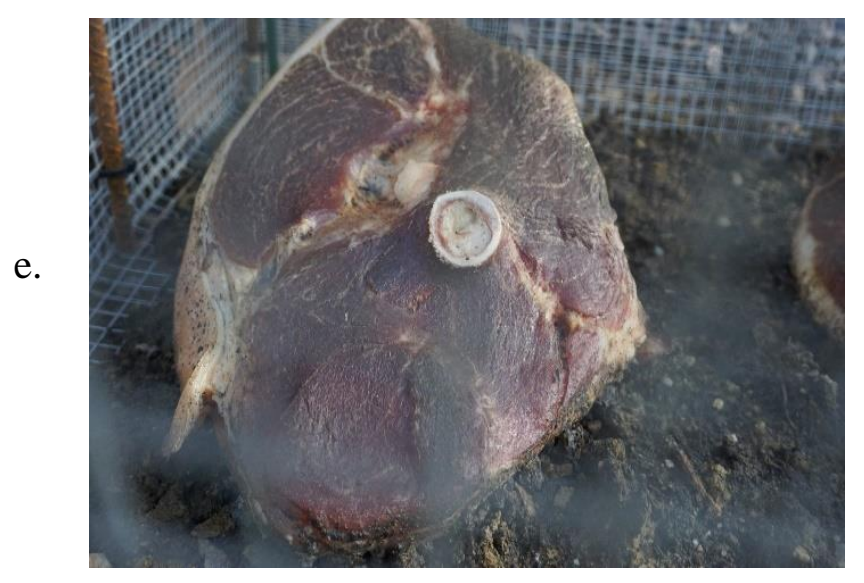

1

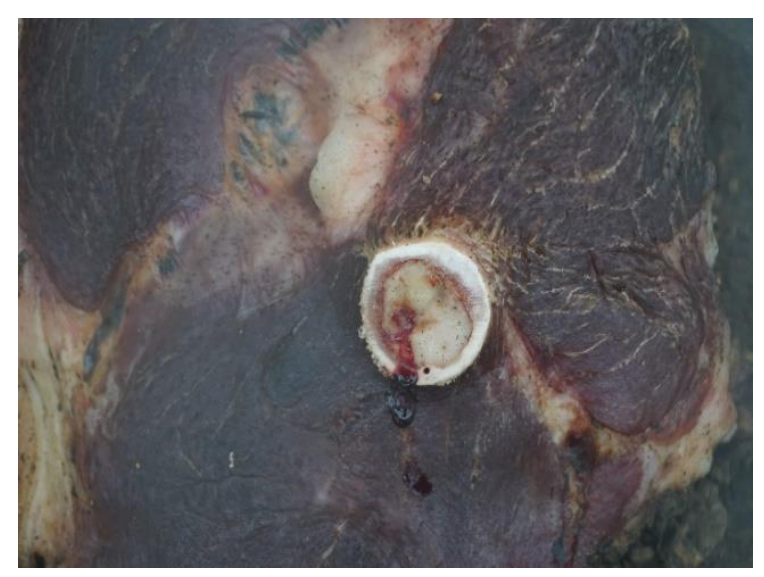

2

Figure 14. Specimen I in February 2018: a1. A light dusting of snow covering the specimen; a2. Specimen completely covered in snow.

b1. Specimen I after the snow had melted; b2. Musculature desiccating and darkening in color.

c1. Snowfall covering surface of specimen; c2. Surface saturated from rain.

d1. Musculature beginning to split apart; $d 2$. Middle section beginning to split.

e1. External surface is desiccated and darker in color; e2. Red fluid emitted from bone marrow. 
a.

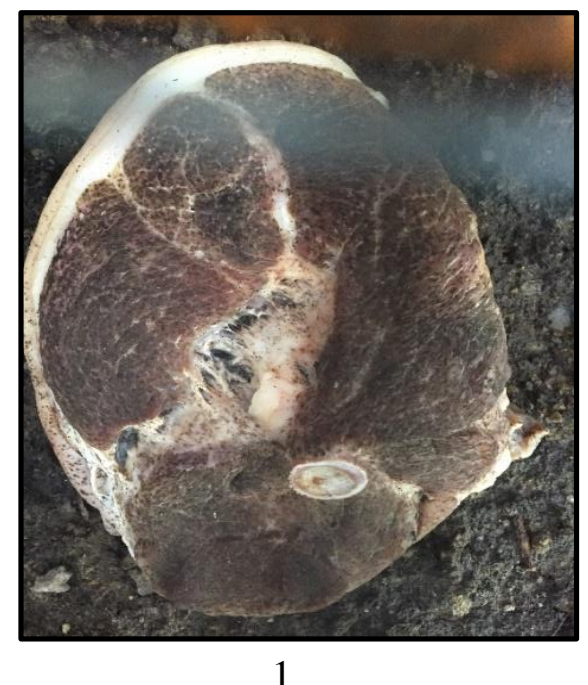

b.

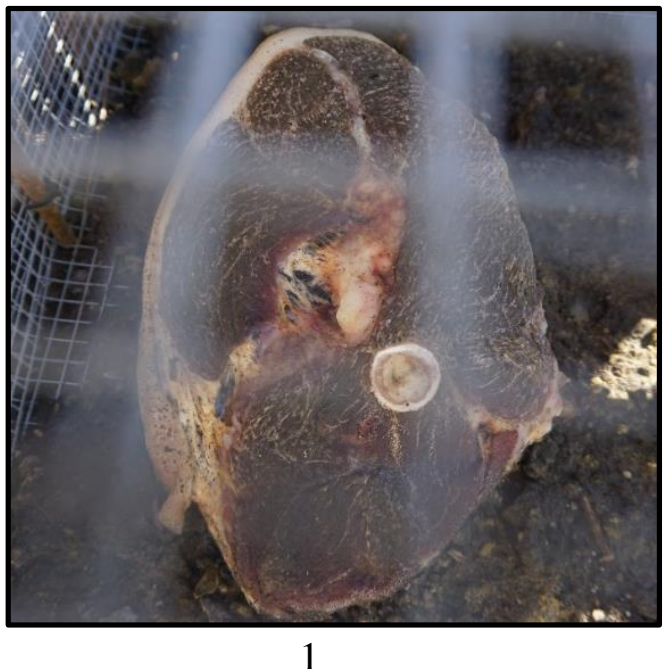

c.

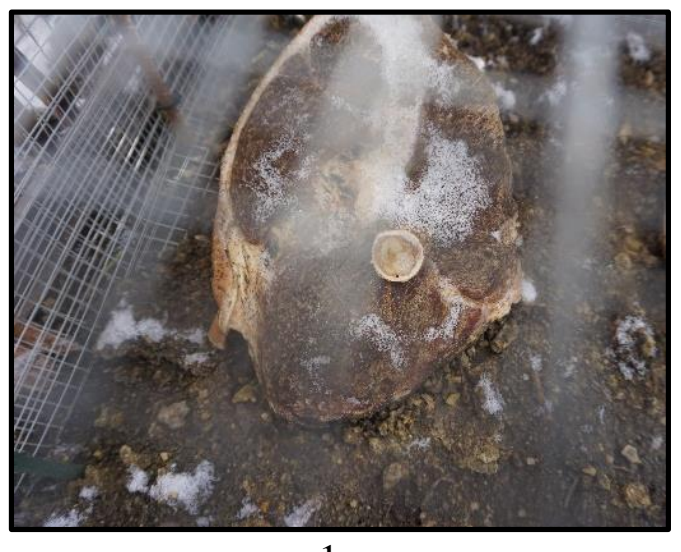

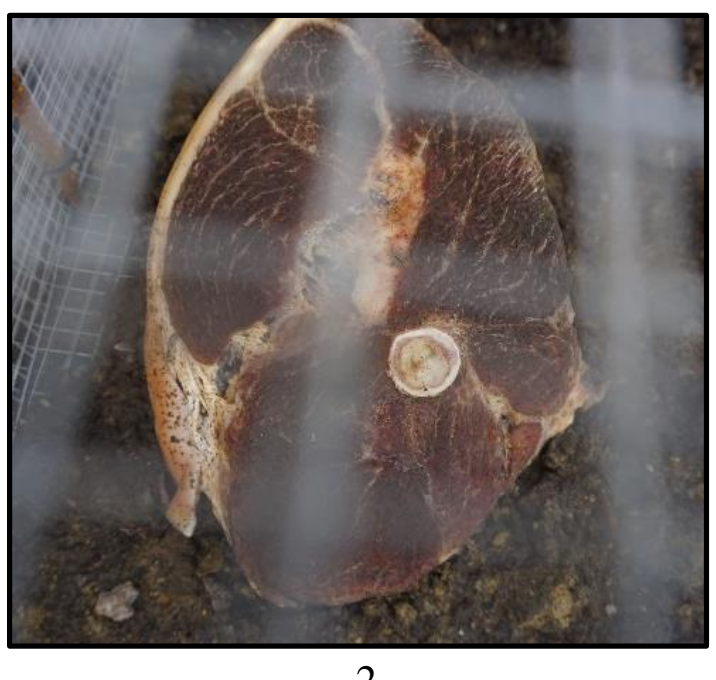

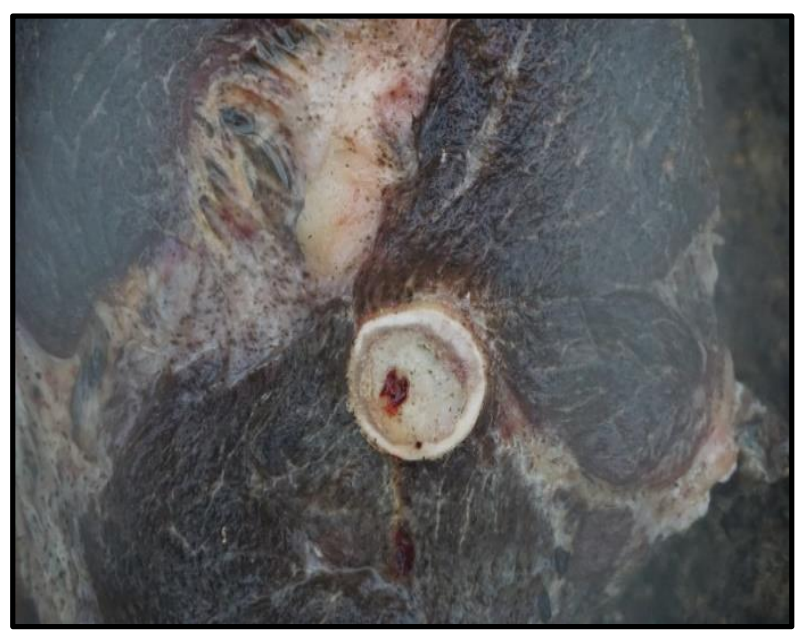

2

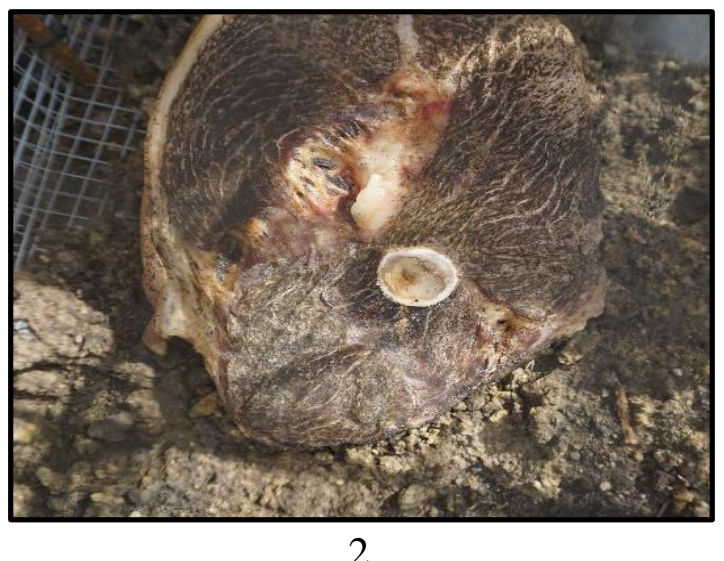


d.

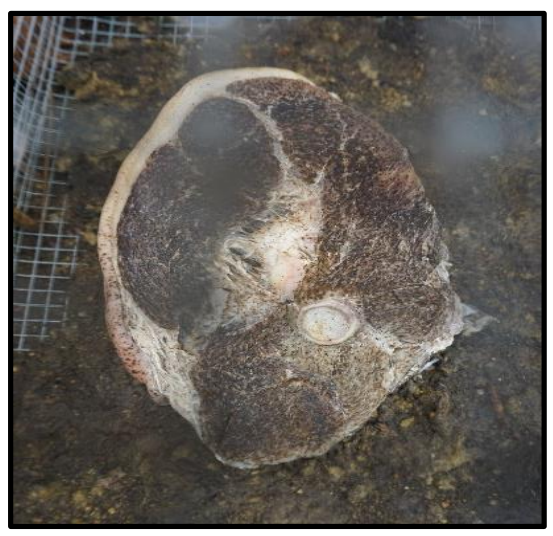

1

e.

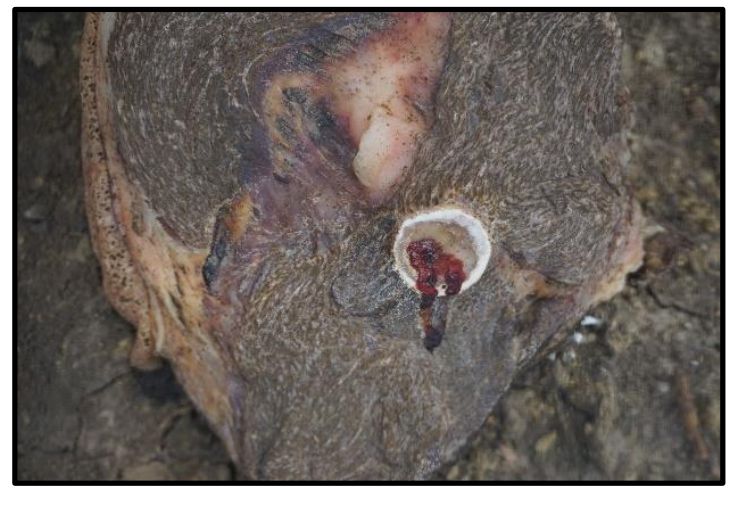

1

f.

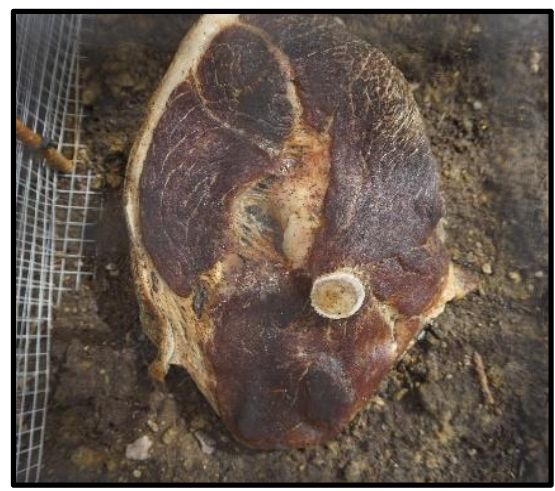

1

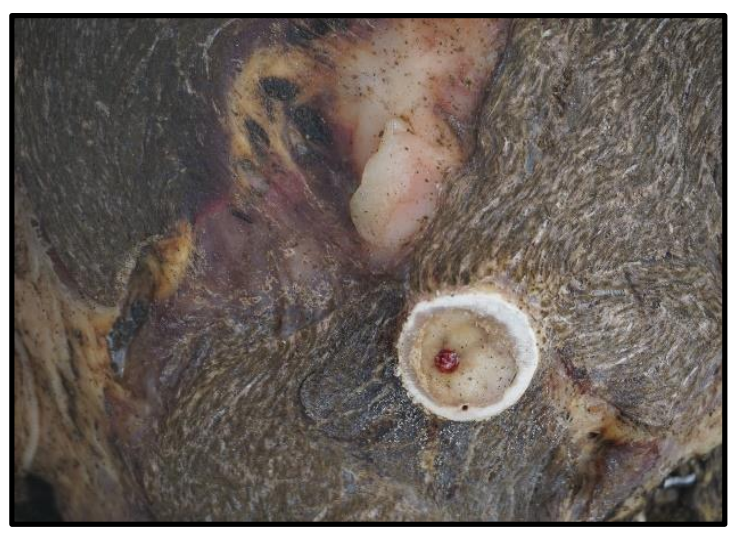

2

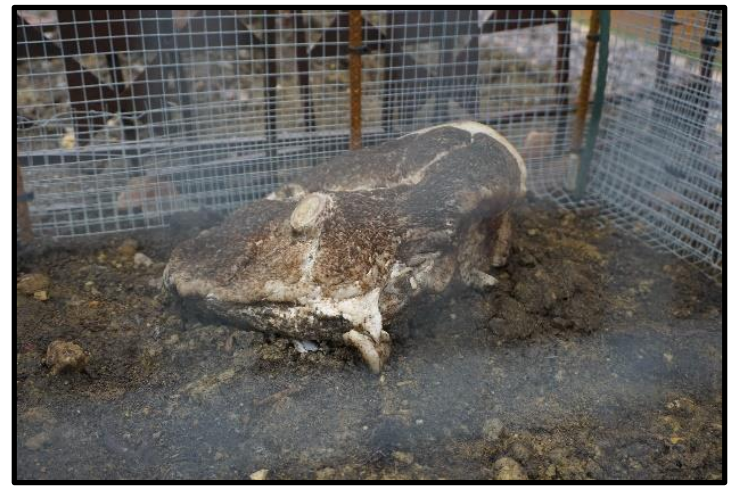

2

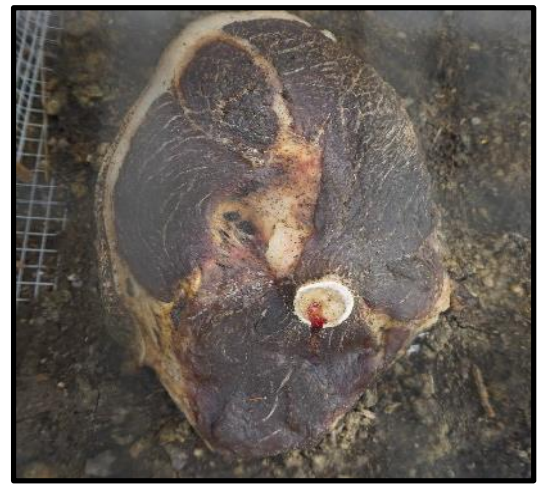

2

Figure 15. Specimen I in March 2018: a1. Contrast in coloration; a2. Fat turning more yellow in coloration.

b1. Streaks of fat visible throughout musculature; b2. Bone marrow change in color.

c1. The musculature has areas of freezer burn and light snow; c2. Surface is desiccated.

d1. Rain caused the specimen to appear bleached; d2. Small amount of fluid on marrow.

e1. Prominent amount of fluid flowing from marrow; e2. Specimen has shrunk vertically.

f1. Musculature darkening in color; f2. Fluid flowing from the marrow. 

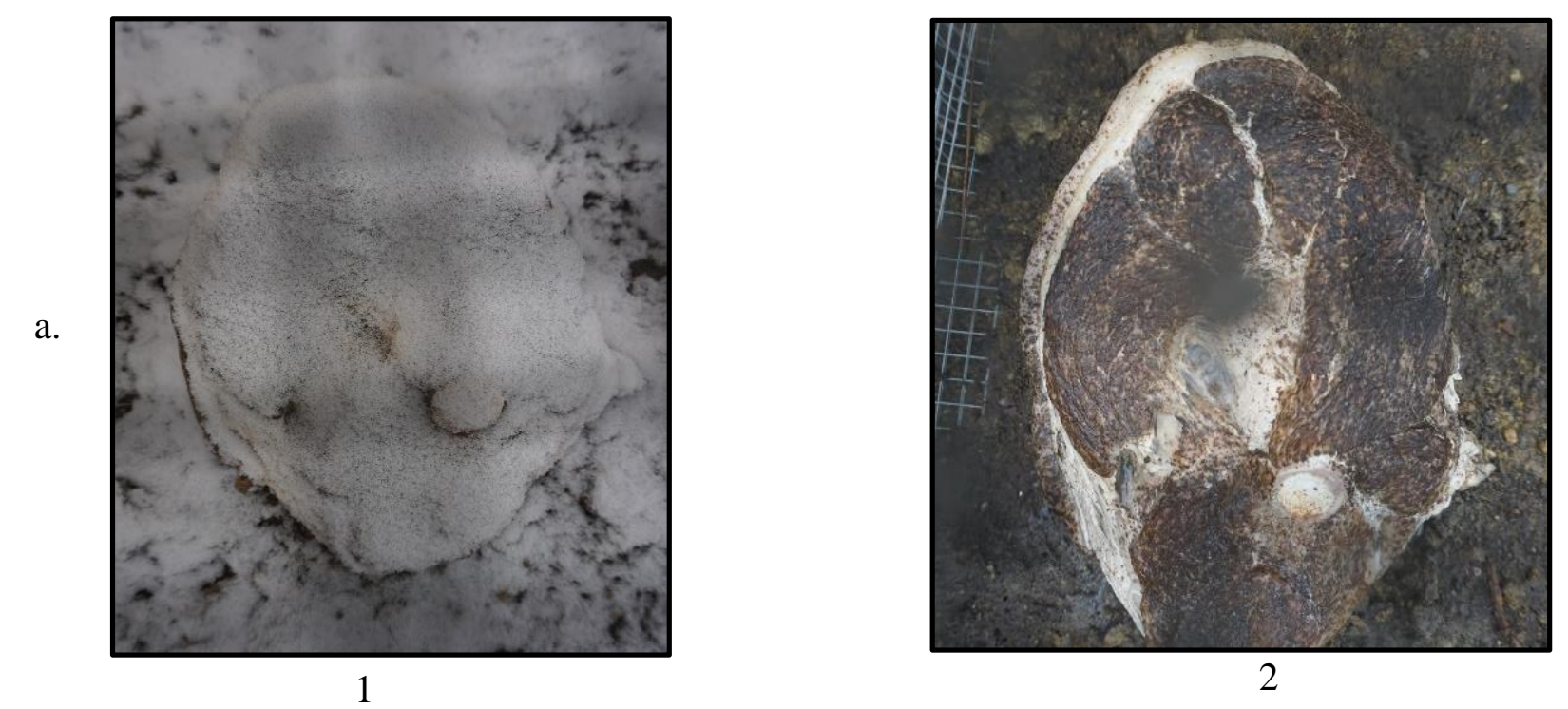

b.
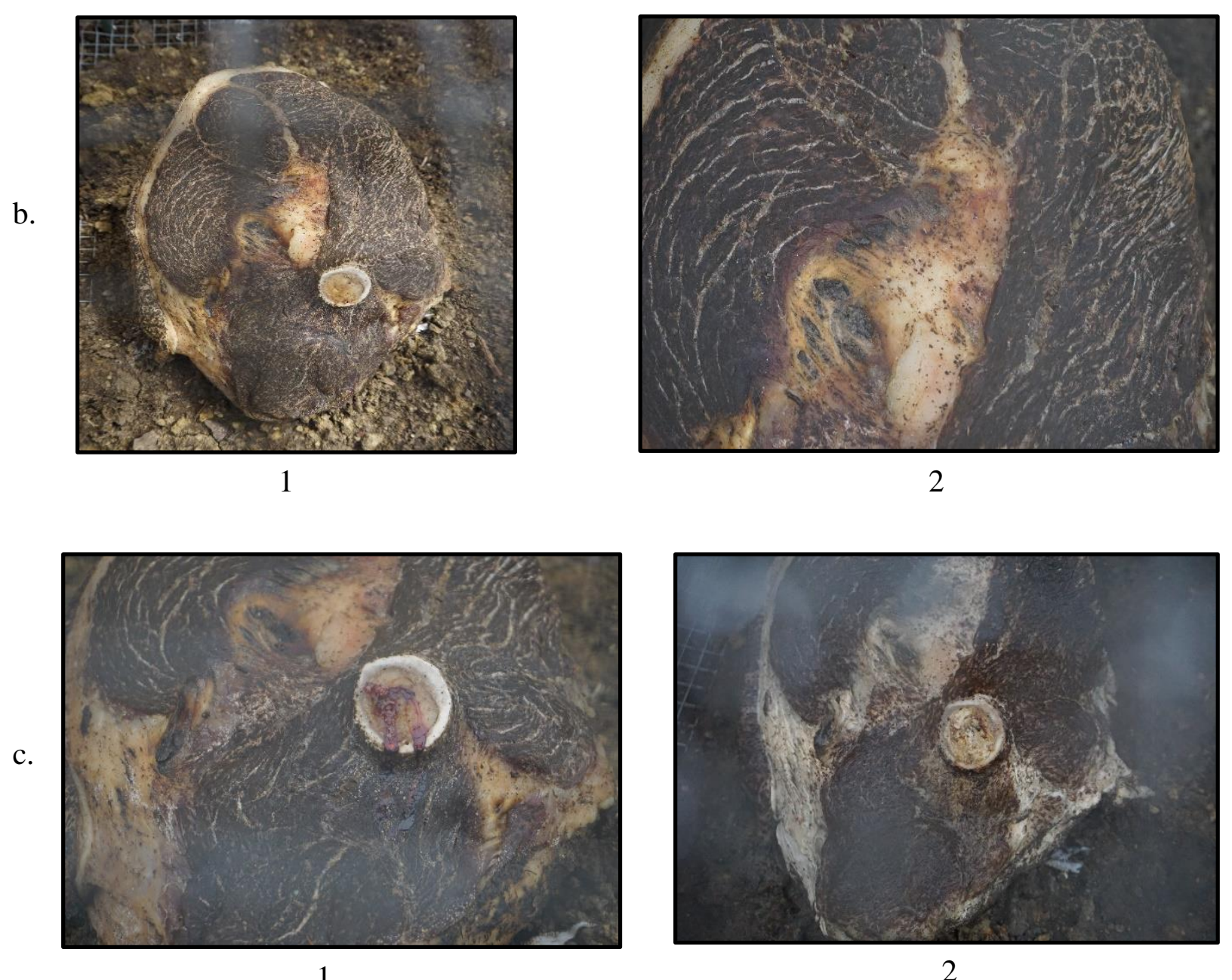

2 

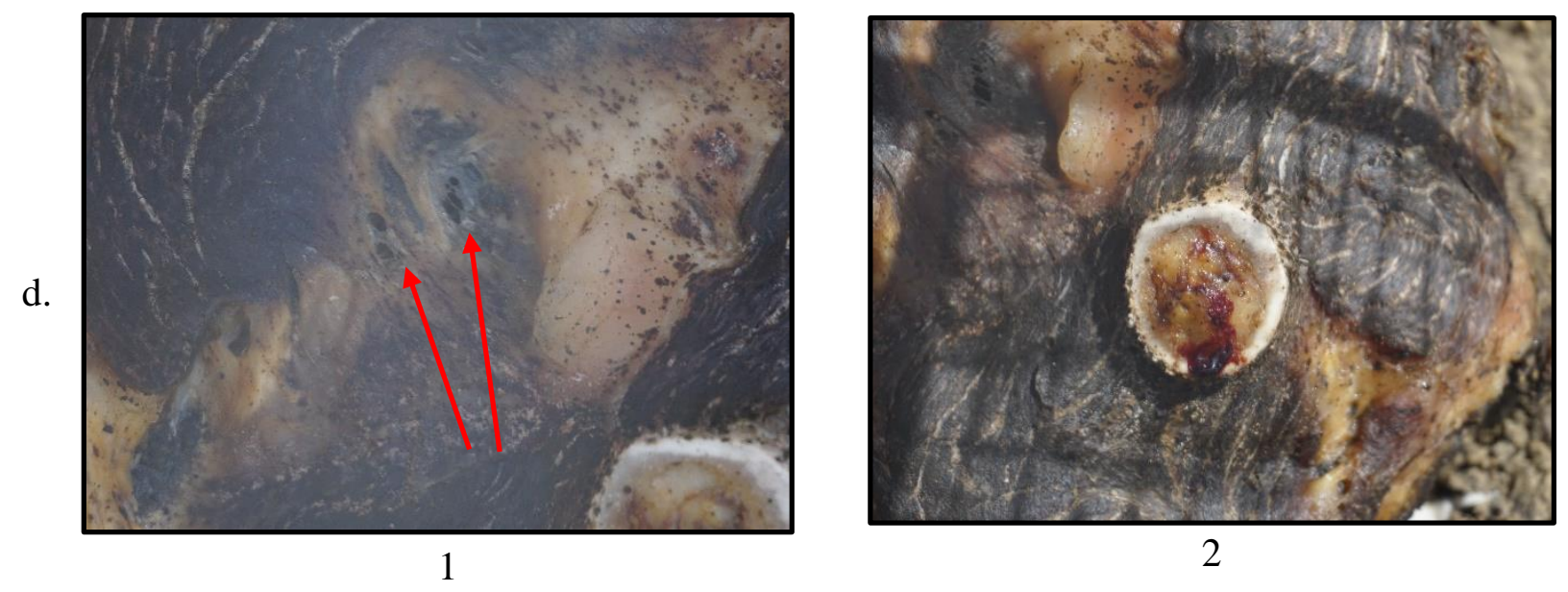

e.
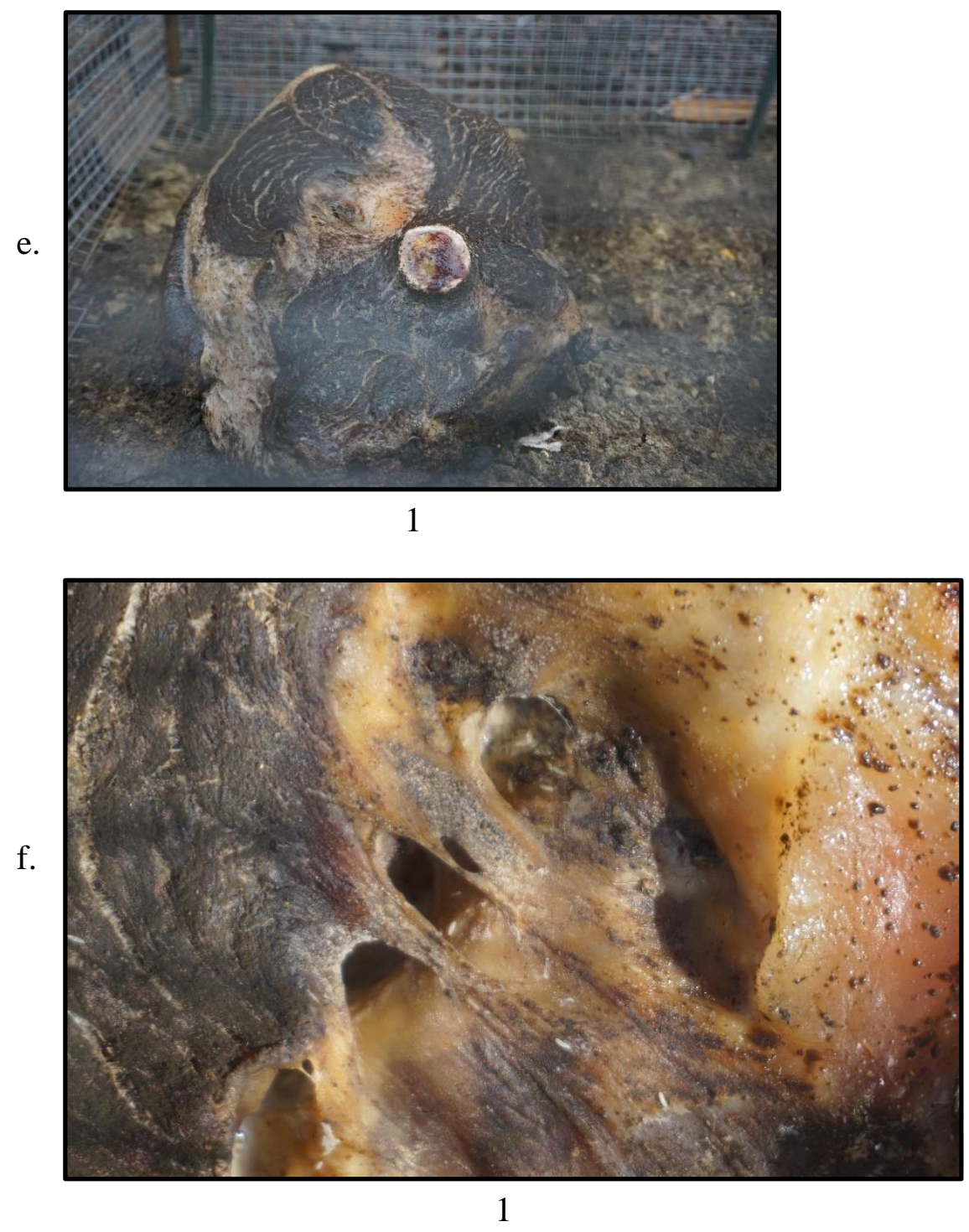

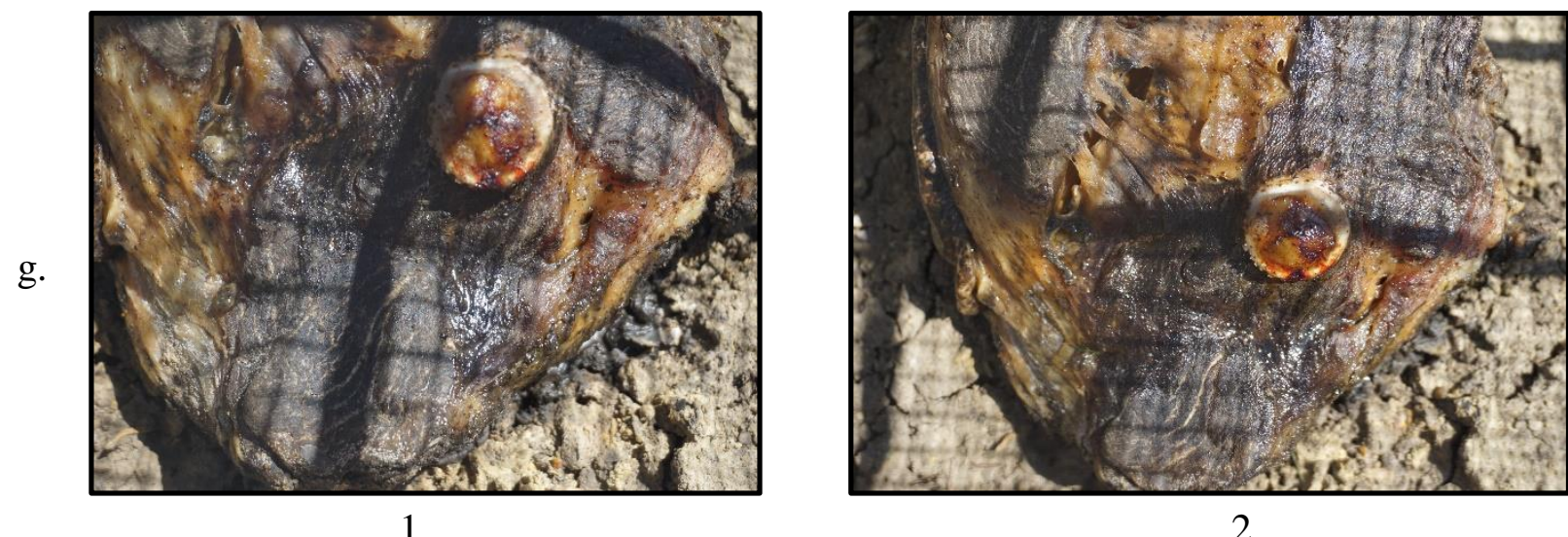

2

Figure 16. Specimen I in April 2018: a1. A light amount of snow on the specimen; a2. Bleached coloration after a period of rain.

b1. External surface is more desiccated; b2. Fat starting to spread apart.

c1. Areas of red fluid seeping from bone marrow; c2. Excess moisture on surface.

d1. Small holes had formed in middle of specimen; d2. Marrow has expanded.

e1. Color of fat and musculature is diluted.

f1. Small maggots visible where holes had formed on the surface.

g1. Decompositional fluids seeping into ground and on specimen; g2. Greater amount of fluid seeping from the specimen. 
a.

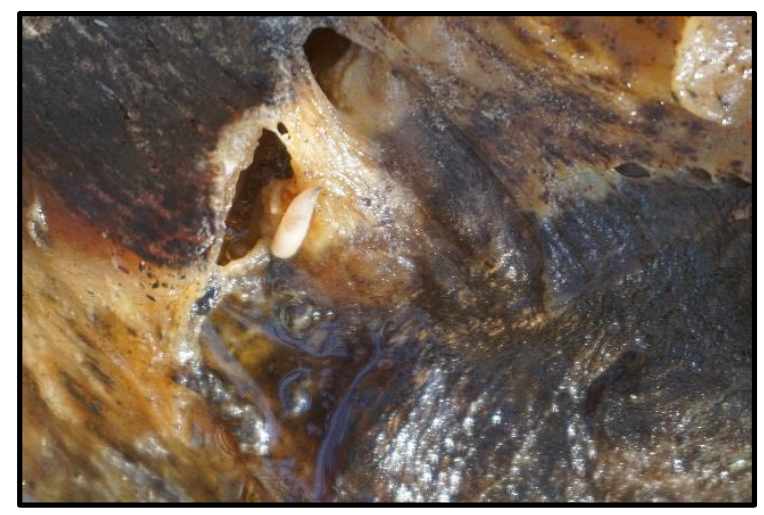

1

b.

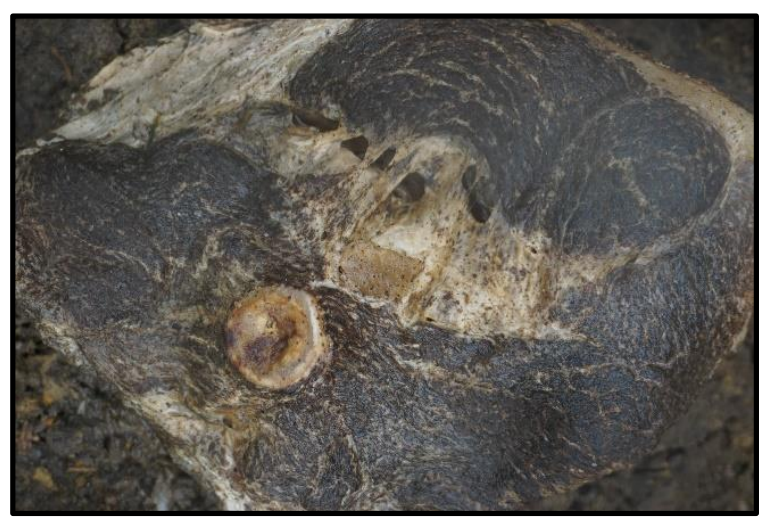

1

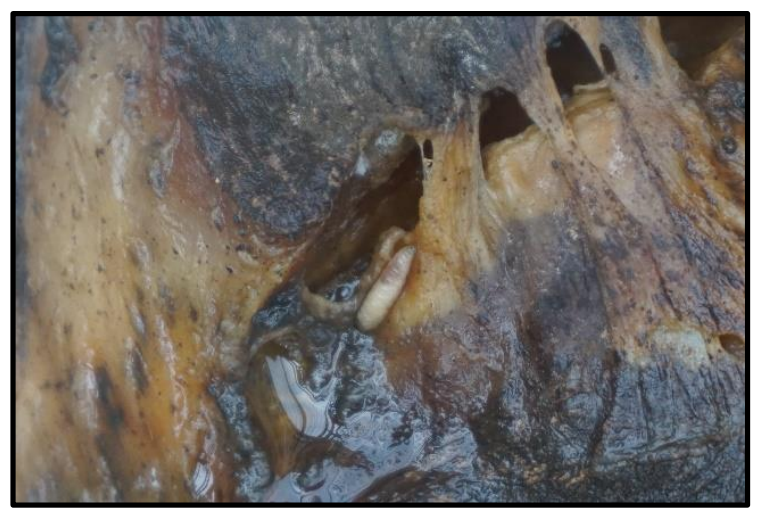

2

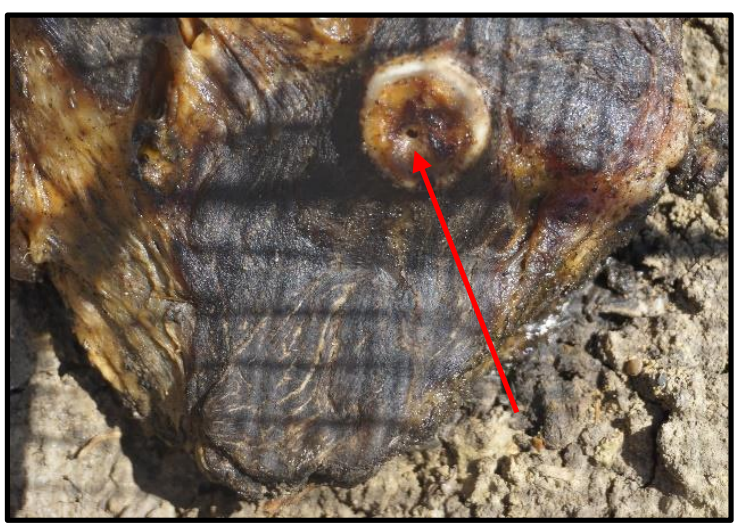

2

c.

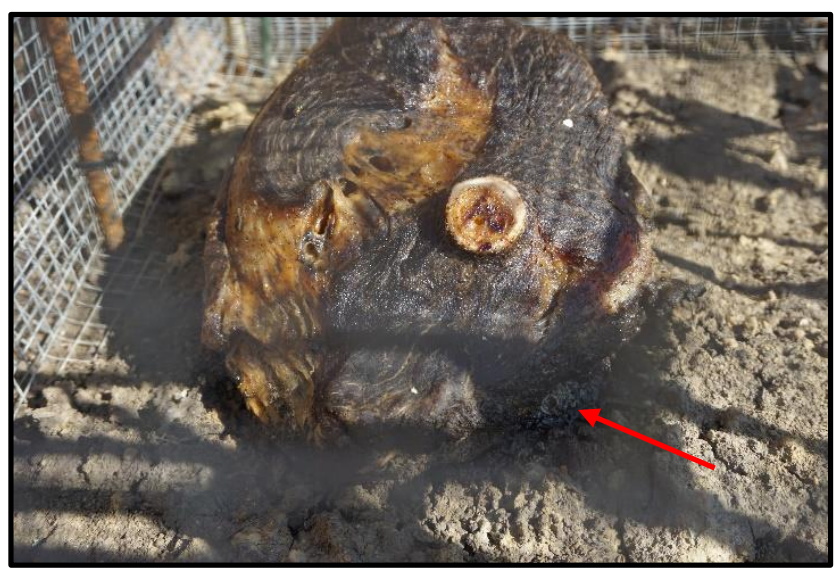

1

Figure 17. Specimen I in May 2018: a1. One maggot on external surface; a2. Maggot on previous day is now dead.

b1. Rain saturated specimen and the marrow in now concave; b2. Small hole in bone marrow.

c1. Maggot mass had formed underneath the specimen. 
a.
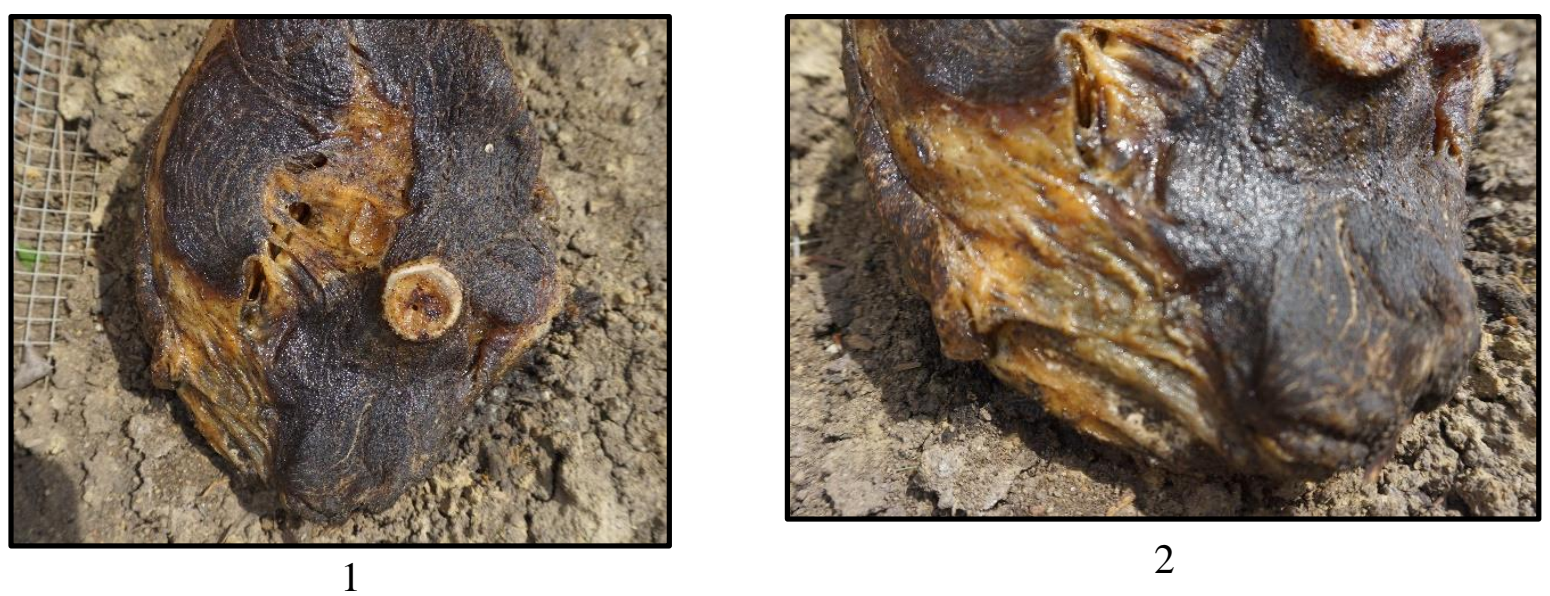

2

b.
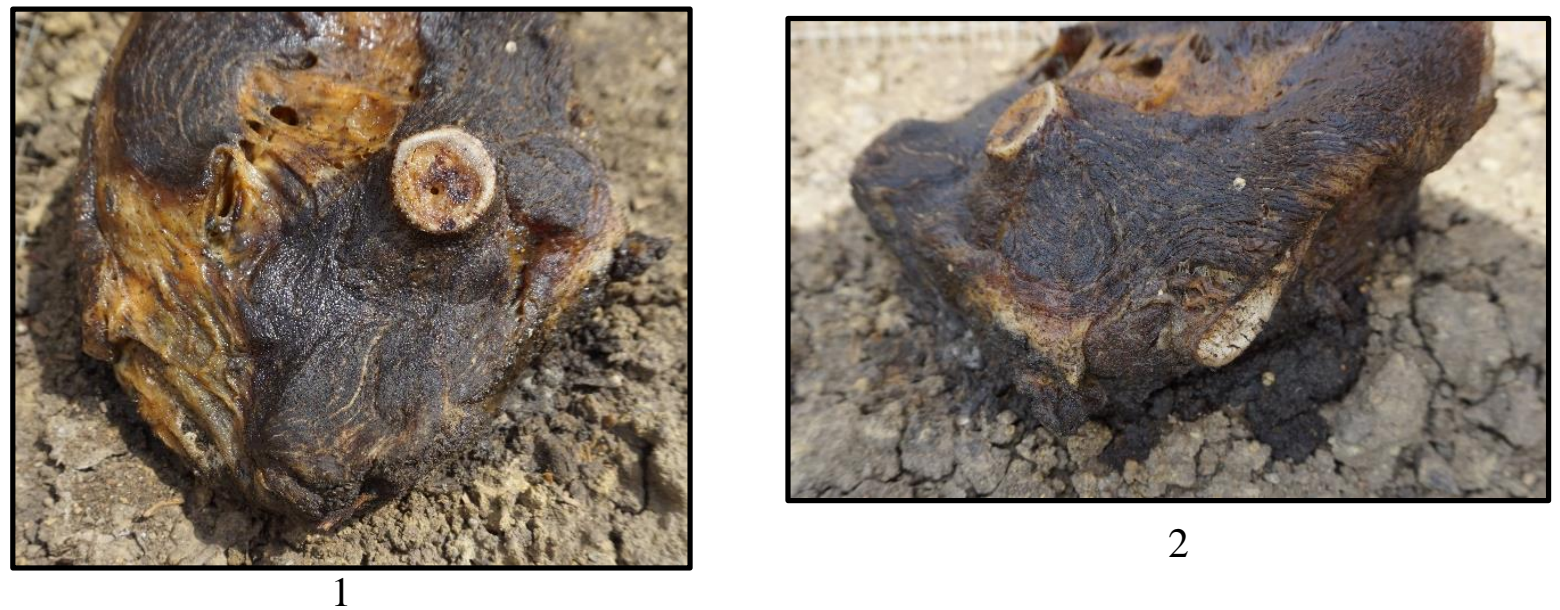

2

c.
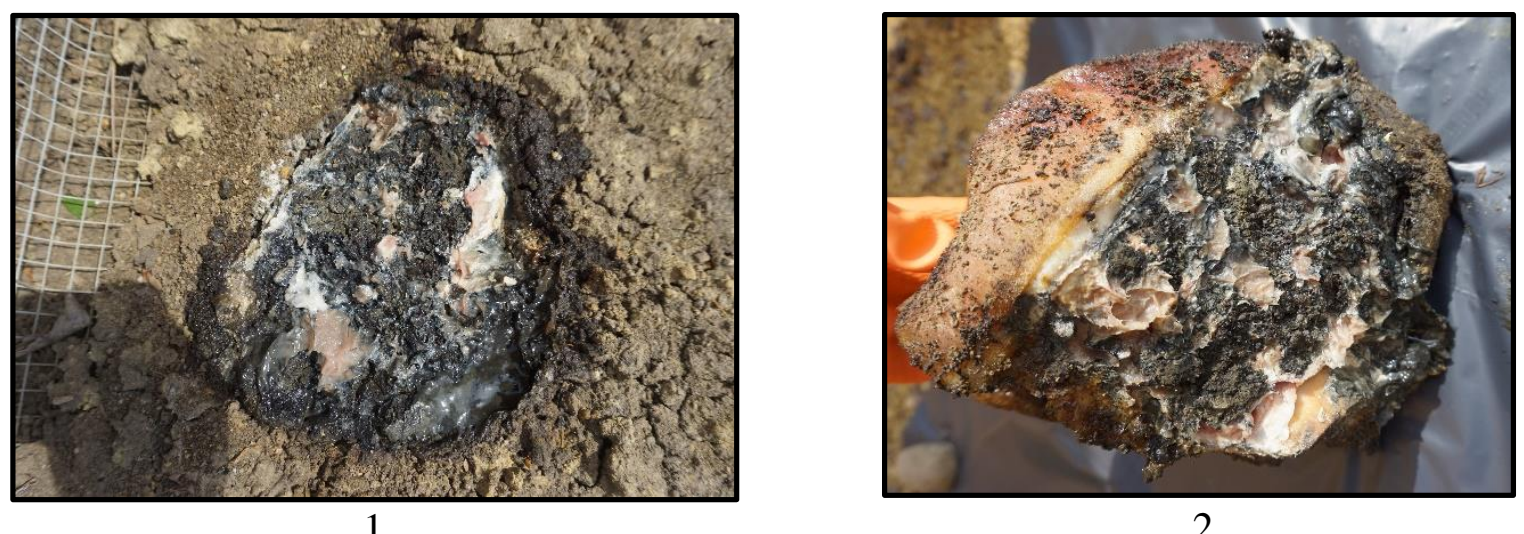

2

Figure 18. Specimen I during the four-month examination: a1. Specimen is blackened and desiccated; a2. Fat at distal end appears yellow/green in color.

b1. Marrow is darker in coloration and a hole is still present; b2. Apparent shrinkage of specimen and moisture accumulation.

c1. Ground surface after specimen was removed; c2. Soil attached to inferior surface. 
APPENDIX B: JANUARY-MAY WEATHER DATA 


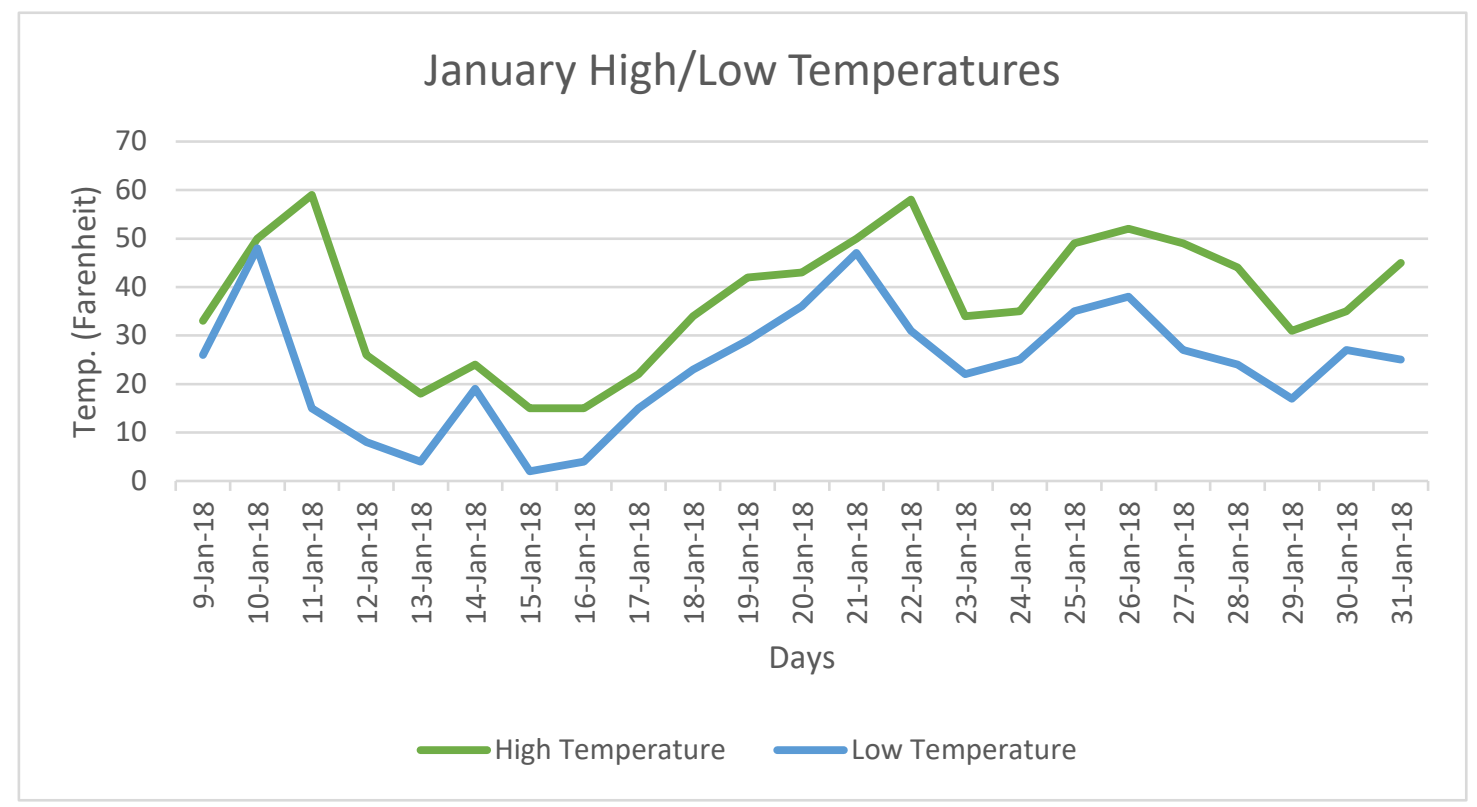

Figure 1. High and low temperatures for the month of January.

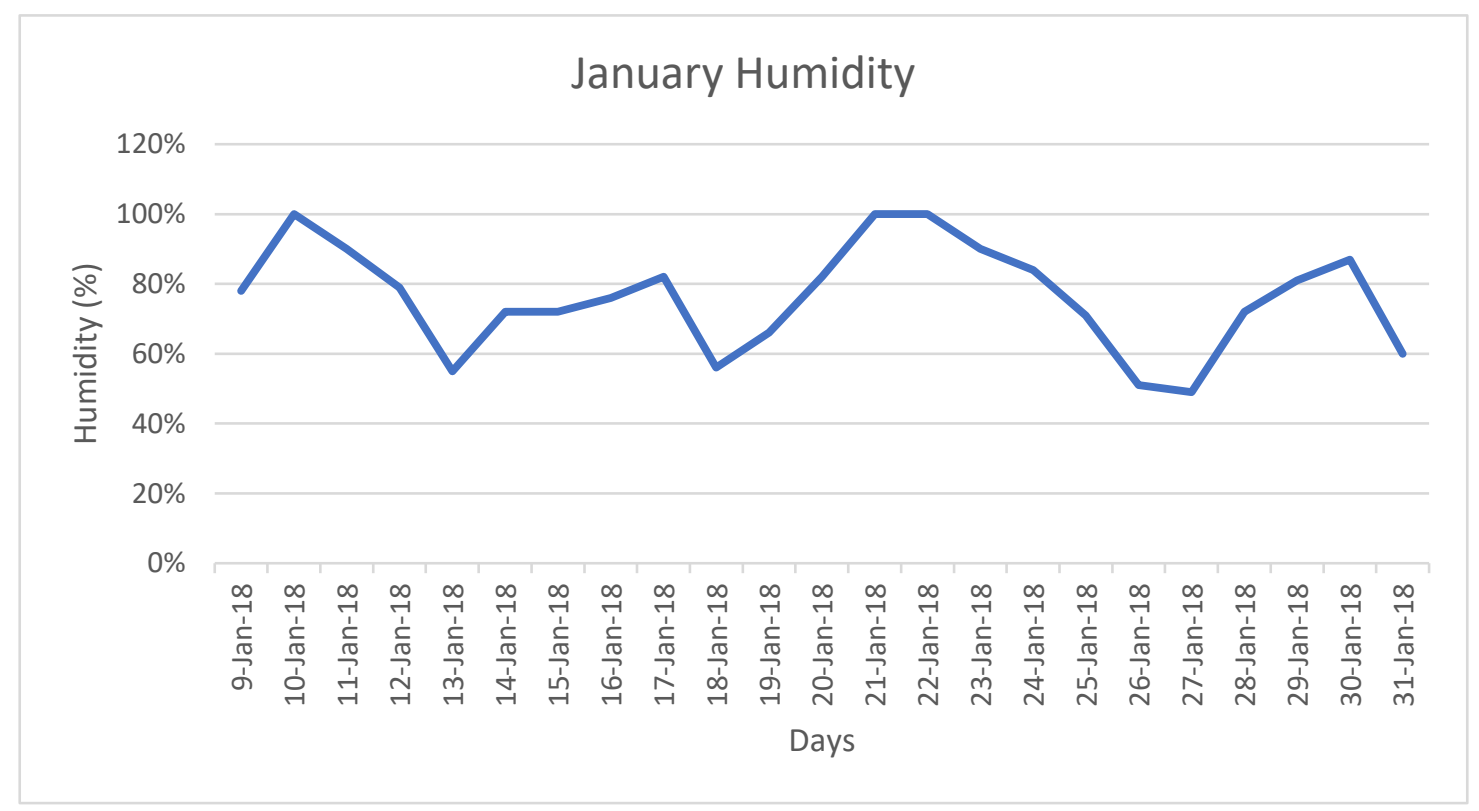

Figure 2. Daily humidity percentage for the month of January. 


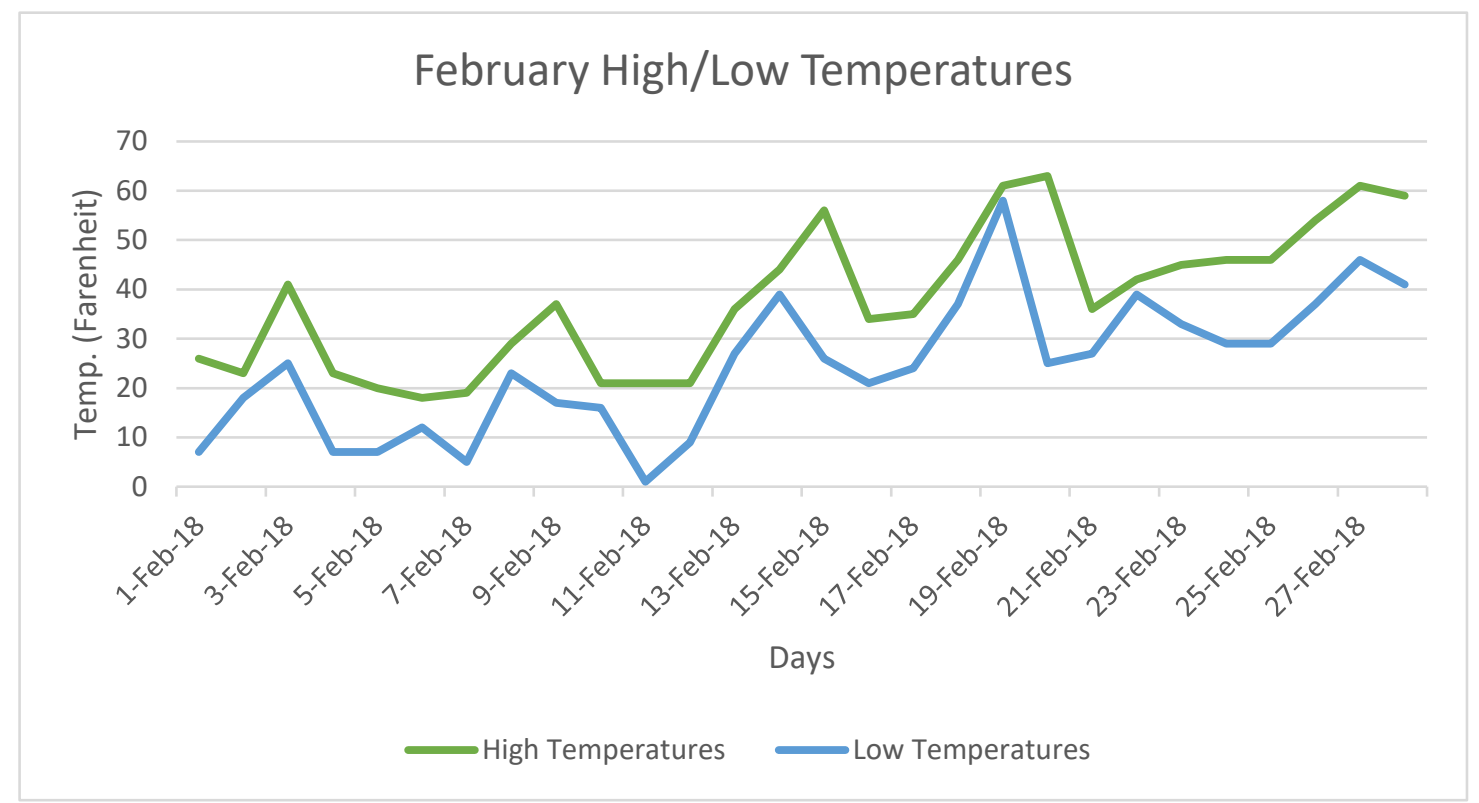

Figure 3. High and low temperature readings for the month of February.

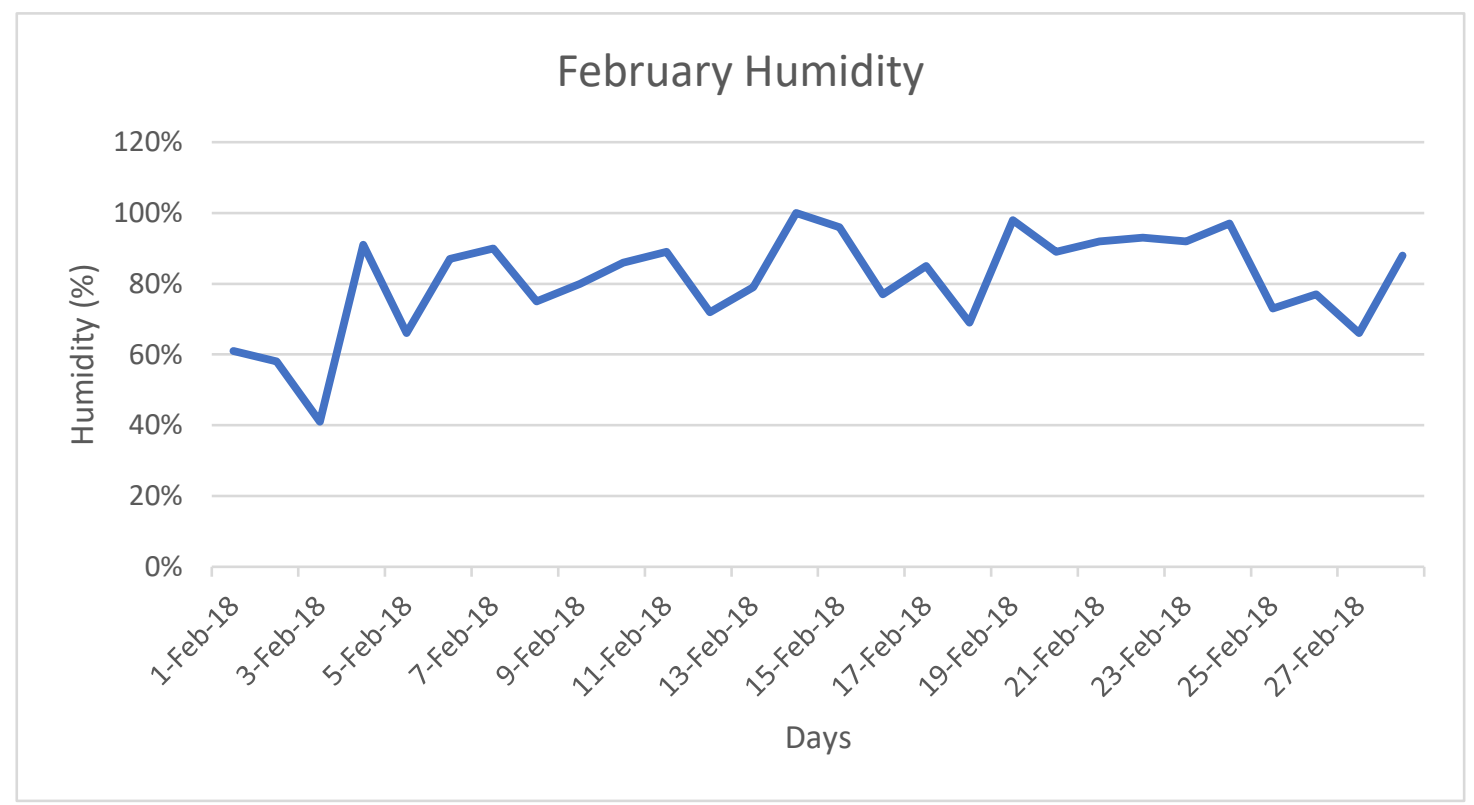

Figure 4. Daily humidity percentage for the month of February. 


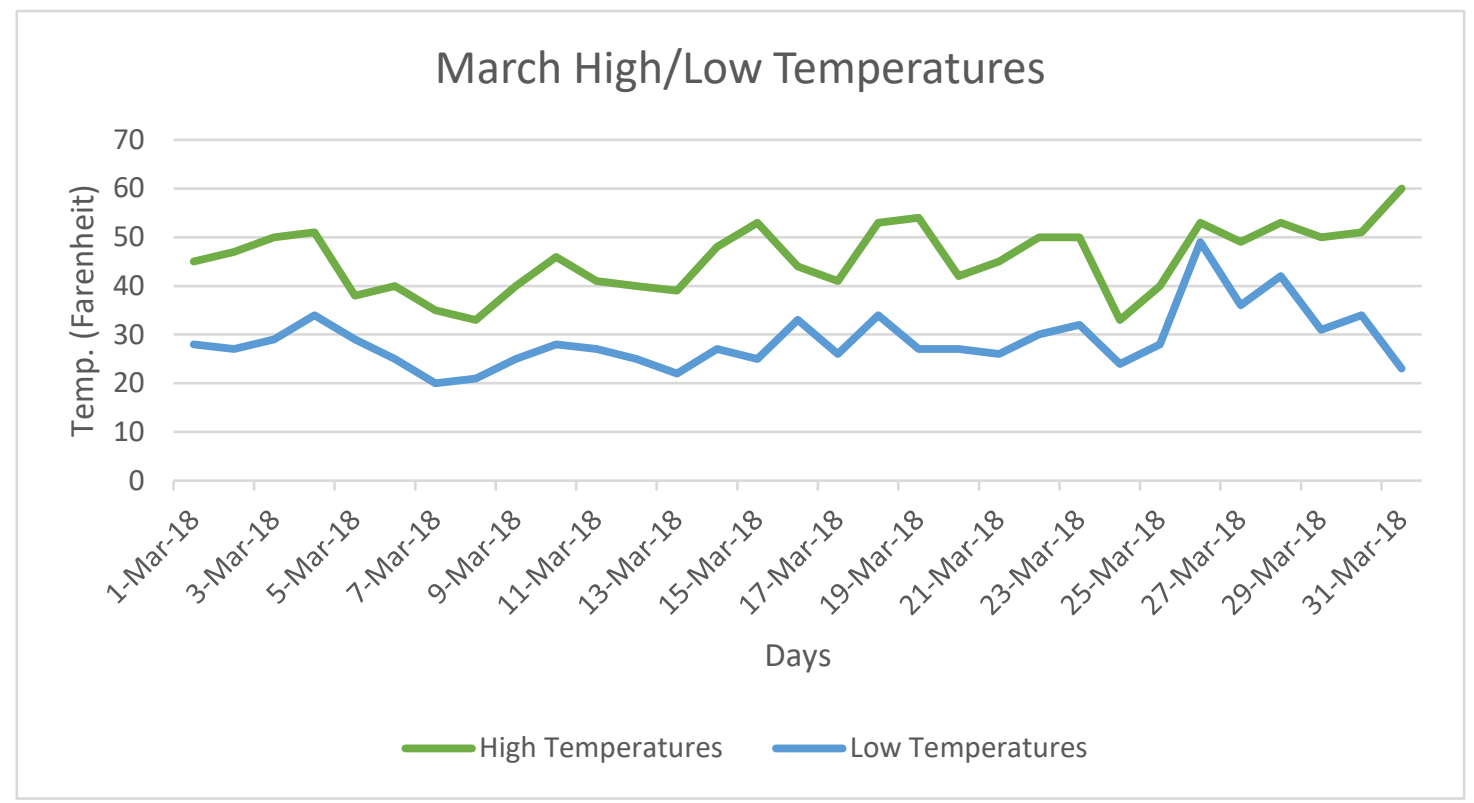

Figure 5. High and low temperature readings for the month of March.

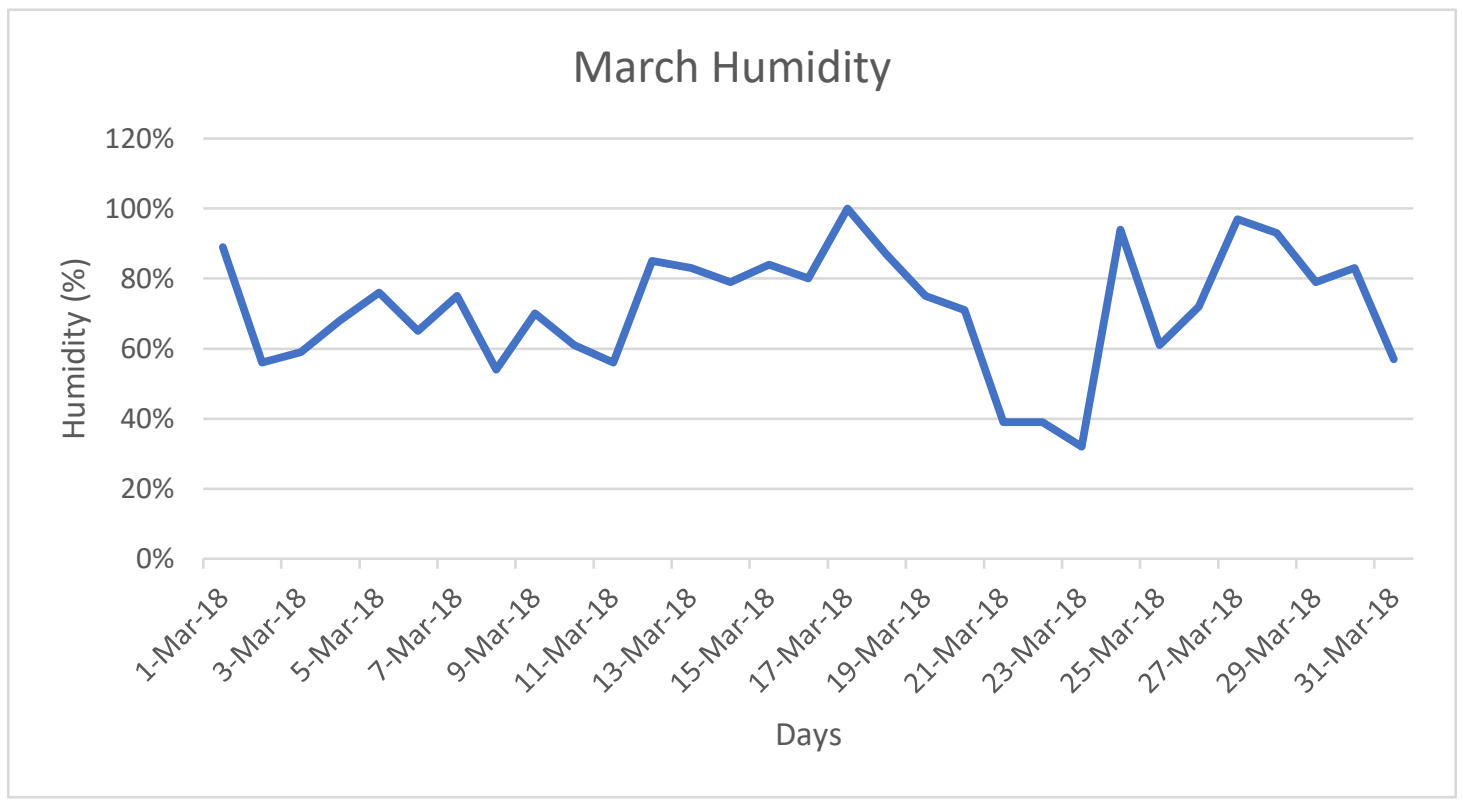




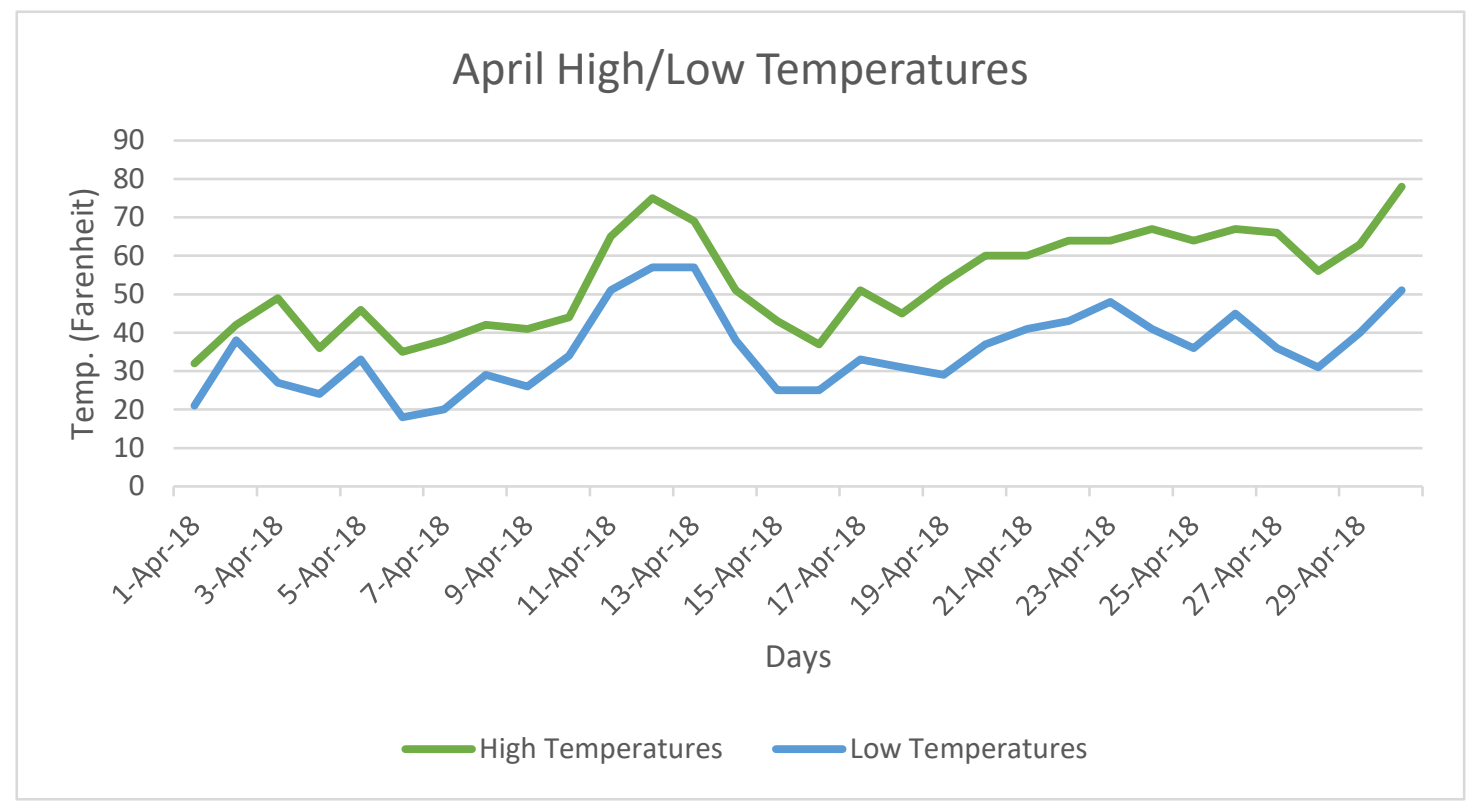

Figure 7. High and low temperature readings for the month of April.

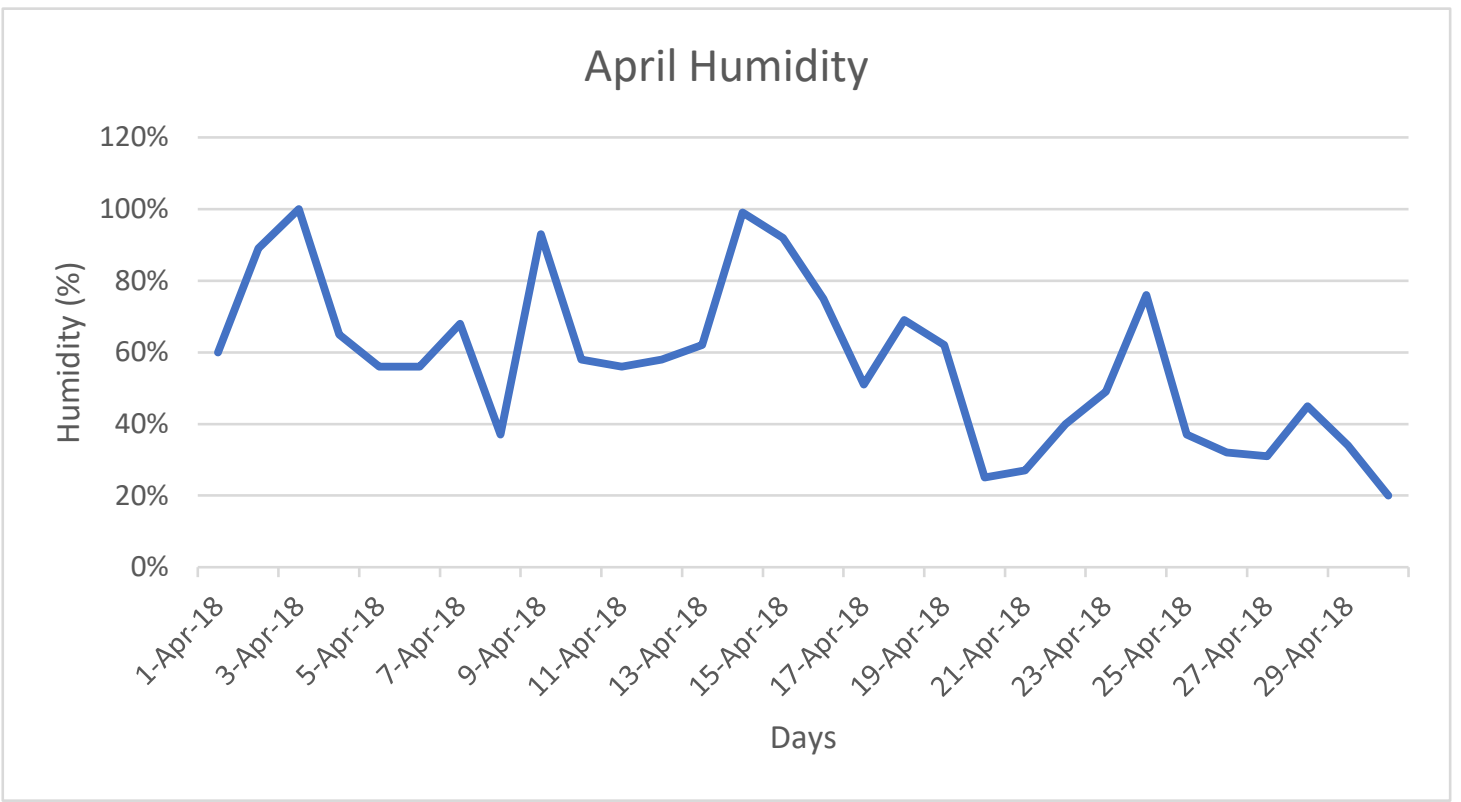

Figure 8. Daily humidity percentage for the month of March. 


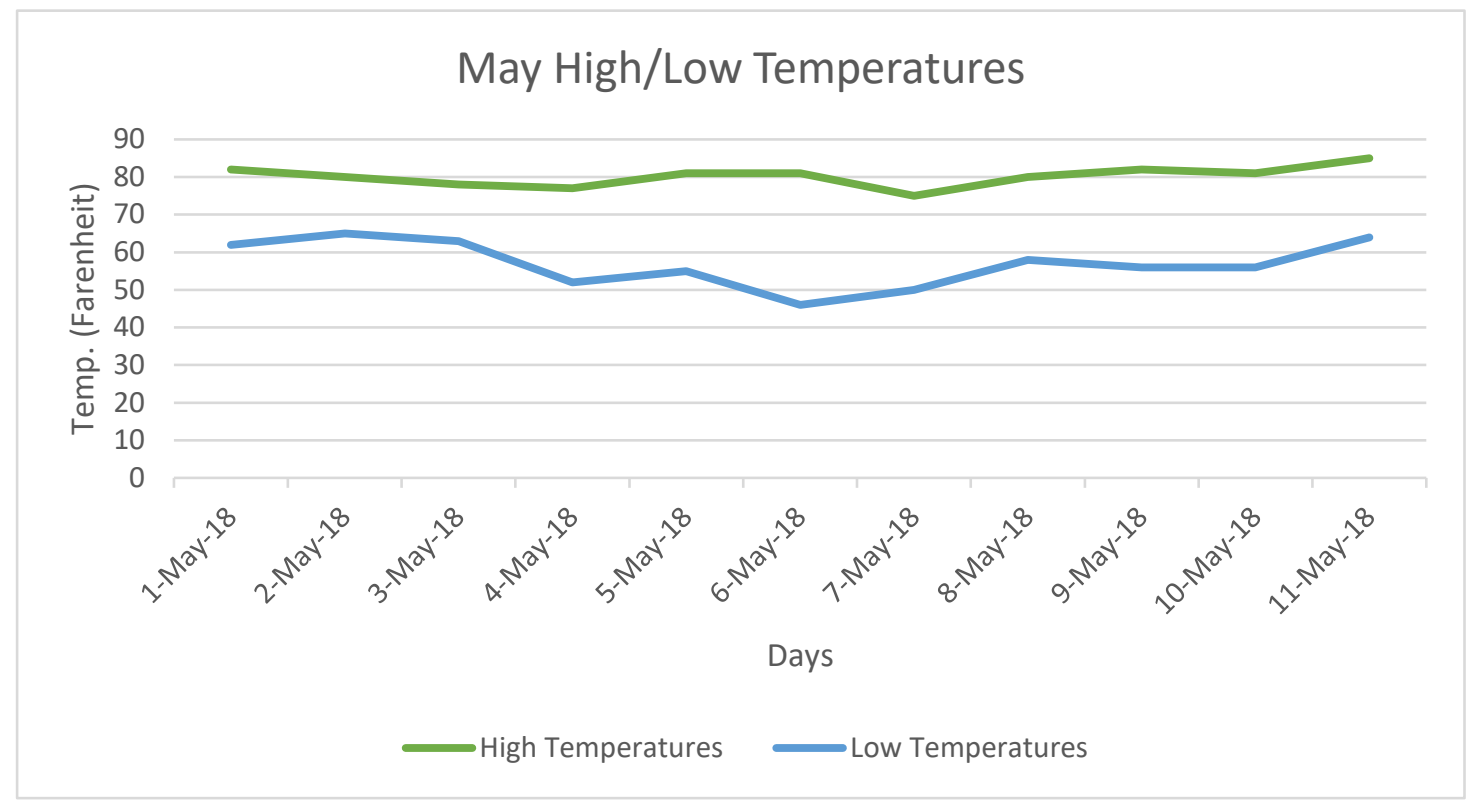

Figure 9. High and low temperature readings for the month of May.

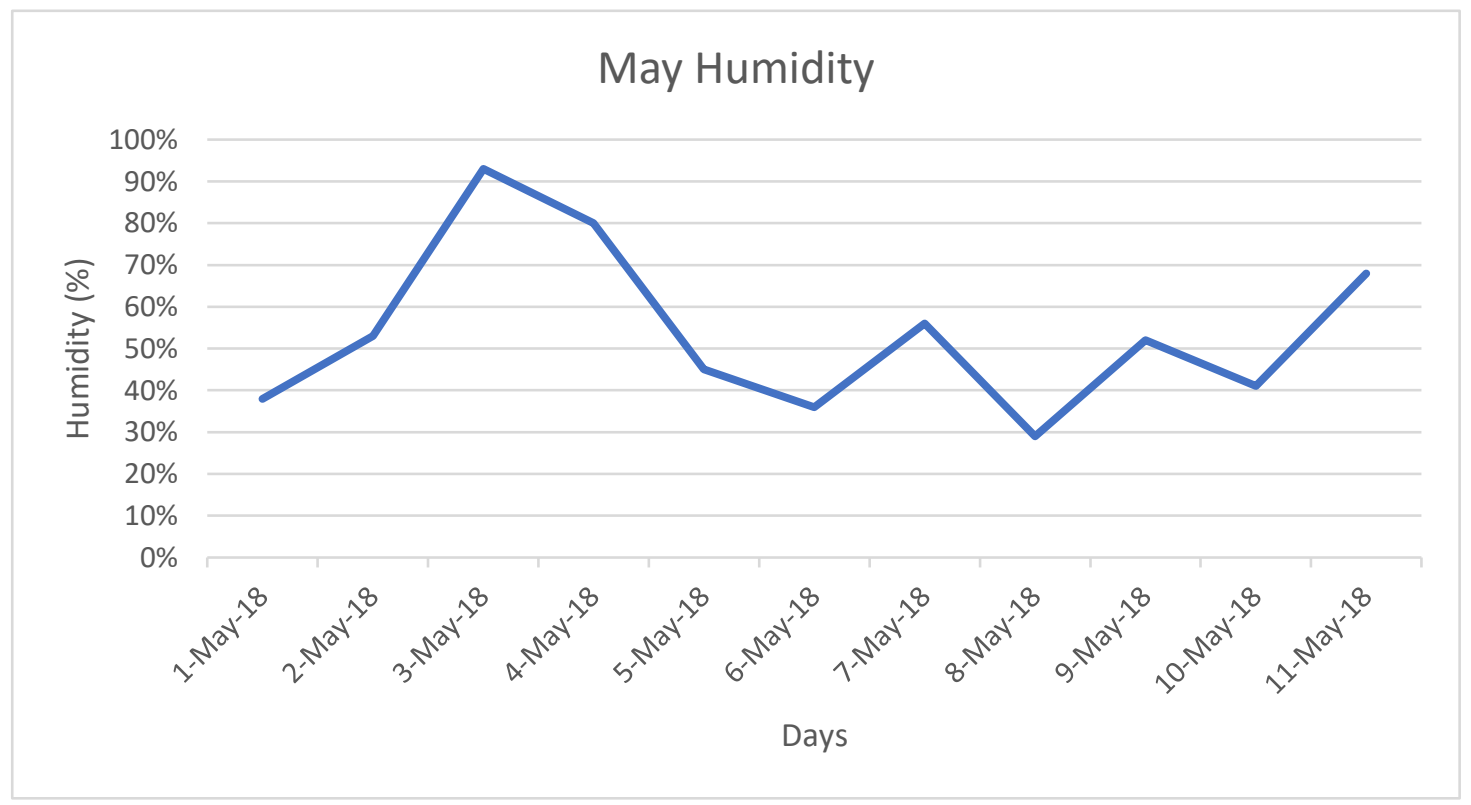

Figure 10. Daily humidity percentage for the month of March. 